\title{
A PRECÍZIÓS SZÁNTÓFÖLDI NÖVÉNYTERMESZTÉS ÖSSZEHASONLÍTÓ VIZSGÁLATA
}


Szerkesztette:

Kemény Gábor

Lámfalusi Ibolya

Molnár András

Szerzők:

Gaál Márta

Kiss Andrea

Péter Krisztina

Sulyok Dénes

Takácsné György Katalin

Domán Csaba

Illés Ivett

Keményné Horváth Zsuzsanna

Opponensek: $\quad$ Dr. Szabó József (MTA ATK Talajtani és Agrokémiai Kutatóintézet)

Dr. Milics Gábor (SZE Mezőgazdaság- és Élelmiszertudományi Kar)

Felelős kiadó: $\quad$ Juhász Anikó

$\begin{array}{lll}\text { Szerkesztőbizottság: } & \text { Biró Szabolcs } & \text { Lámfalusi Ibolya } \\ & \text { Dublecz Károly } & \text { Pető Károly } \\ & \text { Felföldi János } & \text { Potori Norbert } \\ & \text { Fertő Imre } & \text { Rieger László } \\ & \text { Herdon Miklós } & \text { Stummer Ildikó } \\ \text { Illés B. Csaba } & \text { Szakály Zoltán } \\ \text { Kapronczai István } & \text { Szücs István } \\ \text { Káposzta József } & \text { Takács István } \\ \text { Kemény Gábor } & \text { Tóth József } \\ \text { Kertész Róbert } & \text { Tóth Tamás } \\ \text { Keszthelyi Szilárd } & \text { Vágó Szabolcs }\end{array}$

Kiadó:

Agrárgazdasági Kutató Intézet

H-1093 Budapest, Zsil utca 3-5.

Postacím: H-1463 Budapest, Pf.: 944

Telefon: (+36 1) 217-1011

Fax: (+36 1) 217-4469

www.aki.gov.hu

aki@aki.gov.hu

DOI: http://dx.doi.org/10.7896/ak1703

ISBN 978-963-491-601-7

ISSN 2061-8204 (Agrárgazdasági Könyvek sorozat)

Nyomda, kötészet: Primerate Kft.

(C) Agrárgazdasági Kutató Intézet

Minden jog fenntartva. A kiadvány bármely részének sokszorosítása, adatainak bármilyen formában (nyomtatva vagy elektronikusan) történő tárolása vagy továbbítása, továbbá bármilyen elven müködő adatbázis kezelő segítségével történő felhasználása csak a kiadó előzetes írásbeli engedélyével történhet. 


\section{Tartalomjegyzék}

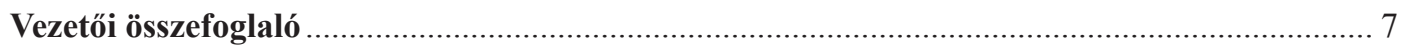

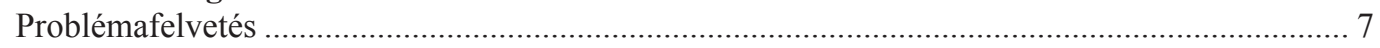

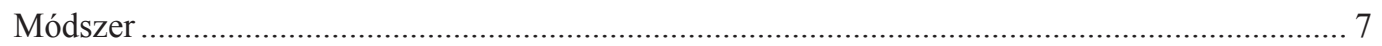

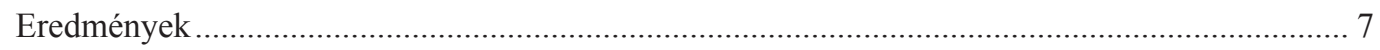

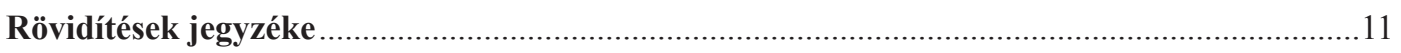

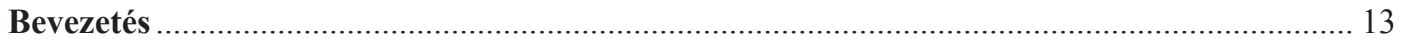

1. A precíziós és a talajkímélő gazdálkodás fogalma és tartalma …........................................ 15

1.1. Precíziós gazdálkodás meghatározása, jellemzői ............................................................ 15

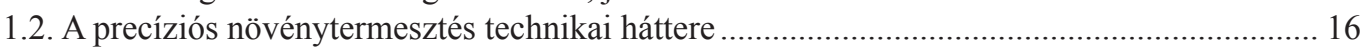

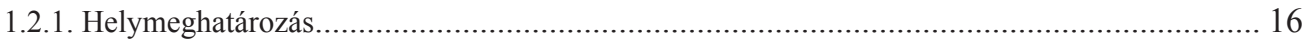

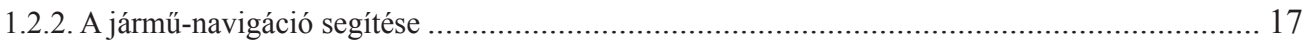

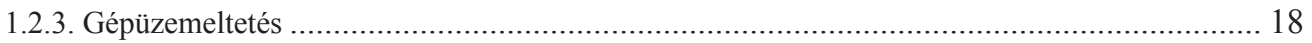

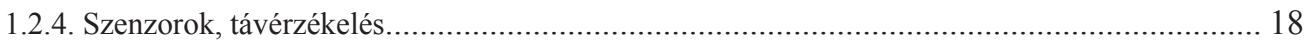

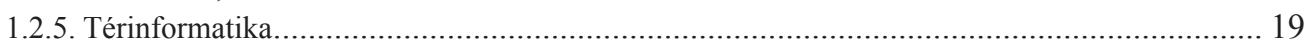

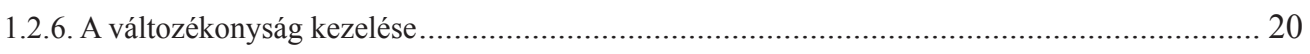

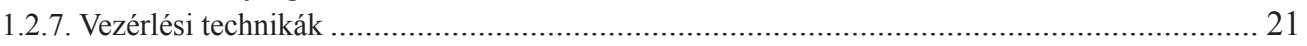

1.3. Szántóföldi növénytermesztésben alkalmazott technológiák ............................................ 21

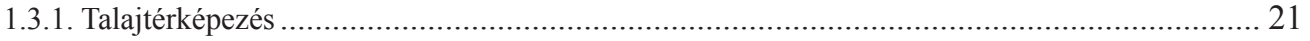

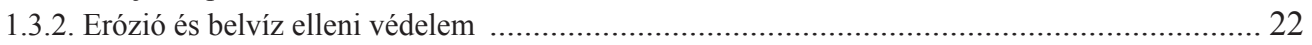

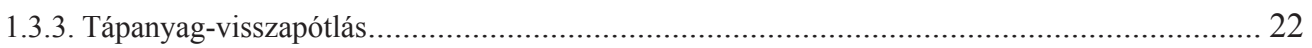

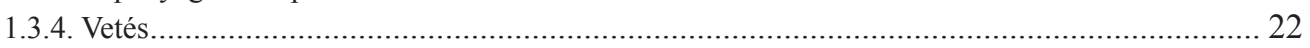

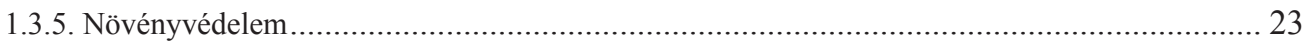

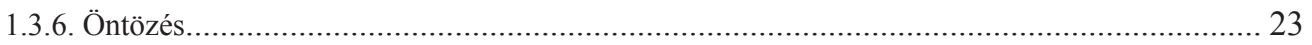

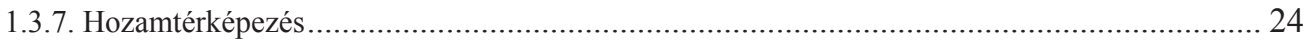

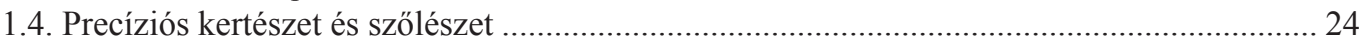

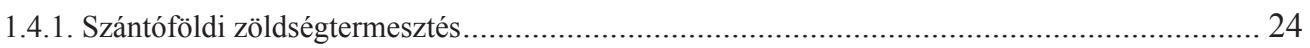

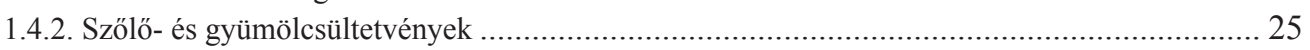

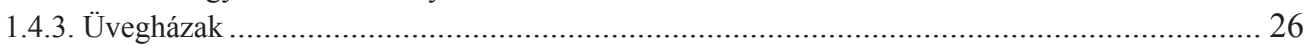

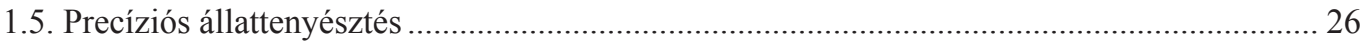

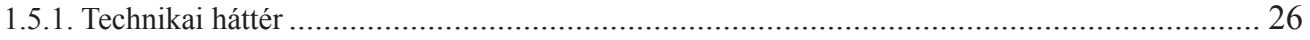

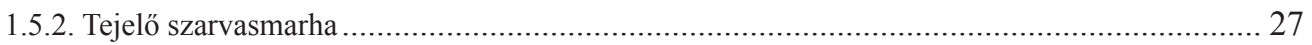

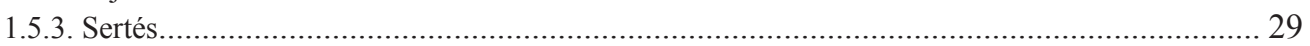

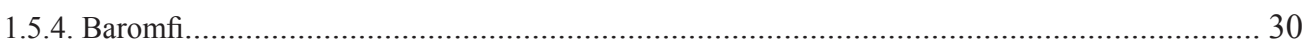

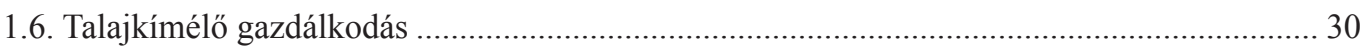

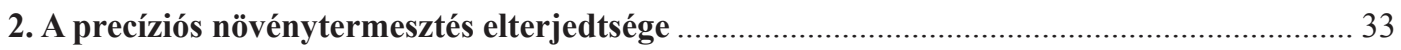

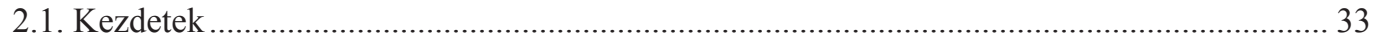

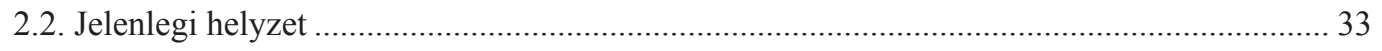

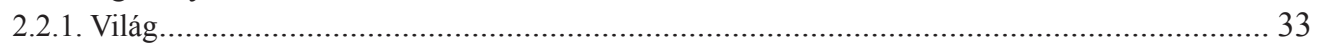

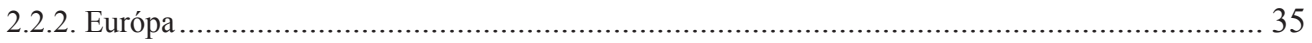

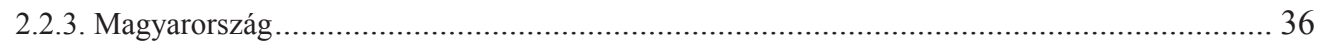

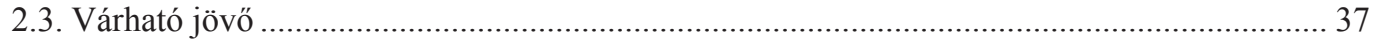

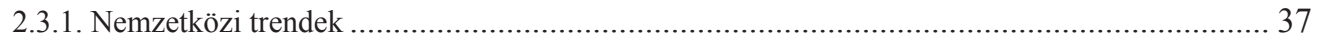

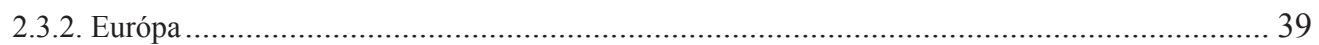

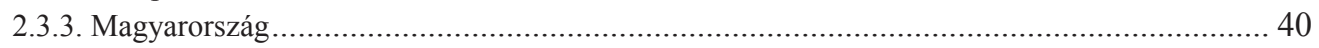


3.1. A precíziós növénytermesztés közgazdasági előnyei, hátrányai ....................................... 41

3.2. A precíziós gazdálkodás bevezetéséhez szükséges többletberuházás megtérülésének vizsgálata és az életképes fedezeti méret.

3.3. A szántóföldi növénytermesztésben alkalmazott precíziós technológia makrogazdasági hatásai

4. Anyag és módszer

4.1. Kérdőíves felméréshez és az ökonómiai vizsgálatokhoz kapcsolódó módszertani megjegyzések

4.2. A mintaüzemek vizsgálatához kapcsolódó módszertani megjegyzések ................................. 54

4.3. A makrobecslés és a beruházásmegtérülési vizsgálatok módszertana.................................. 54

5. A precíziós és a talajkímélő gazdálkodás elterjedtsége, alkalmazásának színvonala és

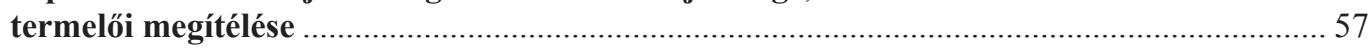

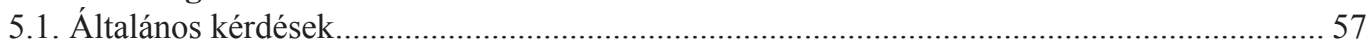

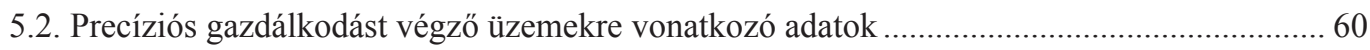

5.3. A talajkímélő müvelési elemeket használó gazdaságok adatai............................................ 67

6. A precíziós gazdálkodást végző és a hagyományosan gazdálkodó üzemek összehasonlítása.....

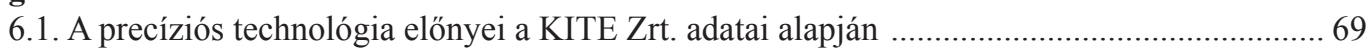

6.2. A mintaüzemek főbb jellemzői és gazdálkodási tapasztalataik ........................................... 75

6.3. A mintaüzemek és a kontrollcsoportok összehasonlítása ................................................ 78

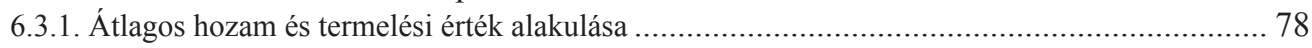

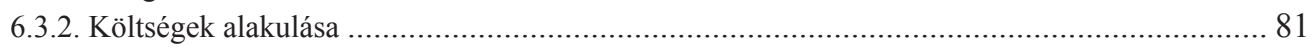

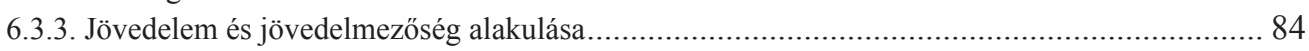

7. A precíziós és talajkímélő gazdálkodást folytató termelők körében végzett statisztikai vizsgálatok.

7.1. A precíziós technológia gazdasági hatásainak kimutatása a 45 üzem körében, a kontrollcsoport adataihoz viszonyítva .....

7.2. A precíziós technológia gazdasági hatásainak kimutatása a 17 üzem körében a

kontrollcsoport adataihoz viszonyítva .....

7.3. A precíziós technológia gazdasági hatásainak kimutatása a 17 üzem körében a

kontrollcsoport megválasztásának módosításával .......................................................... 90

7.4. Eredmények igazolása statisztikai módszerekkel......................................................... 93

7.5. A precíziós technológia gazdasági hatásainak kimutatása a 17 üzem körében 6 év

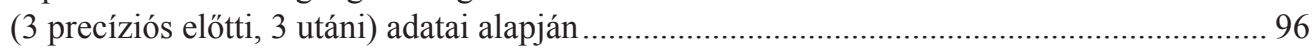

8. A precíziós gazdálkodás becsült makrogazdasági hatásai ................................................ 103

8.1. A precíziós gazdálkodást folytató üzemek és a kontrollcsoport vizsgálatának eredményei 103

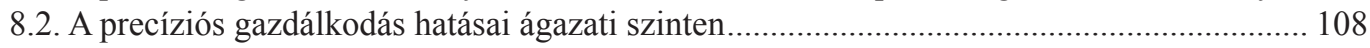

8.3. A precíziós gazdálkodás beruházási költségei ....................................................................114

9. A precíziós gazdálkodás elterjedését befolyásoló tényezők és a korlátok

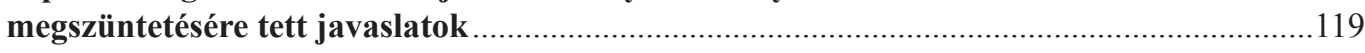

9.1. Az elterjedést korlátozó, illetve segítő tényezők ...........................................................119

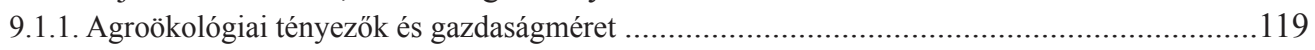

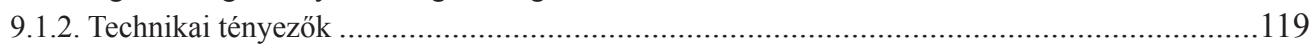

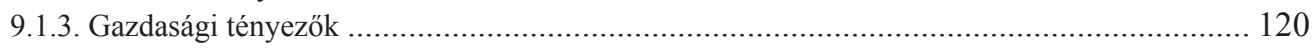

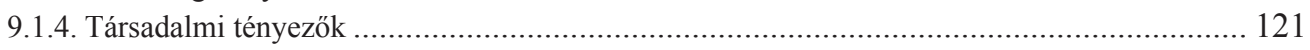

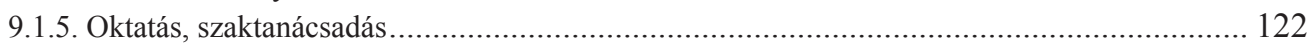




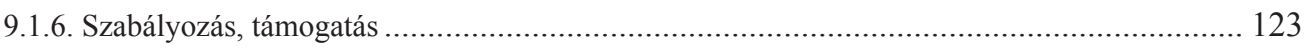

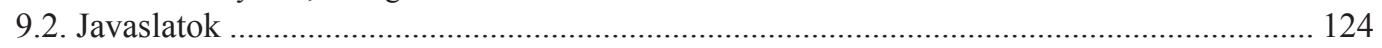

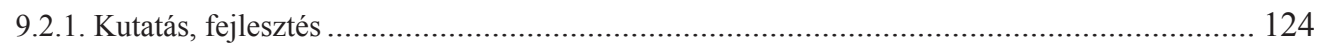

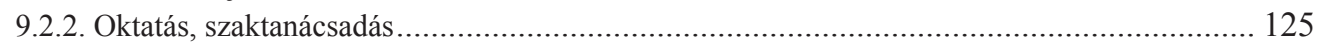

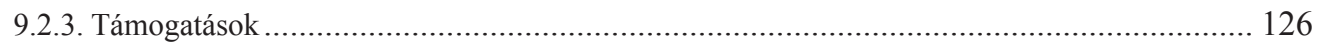

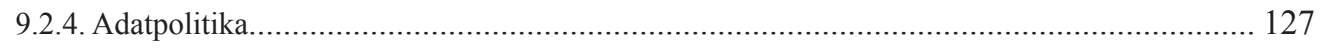

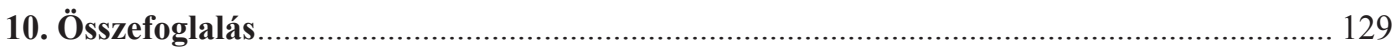

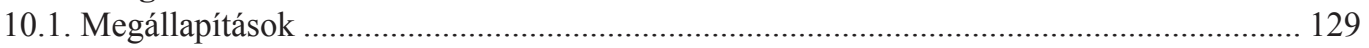

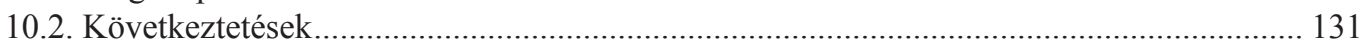

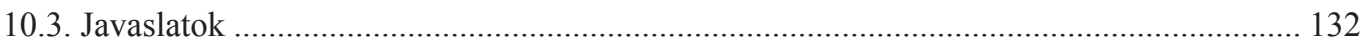

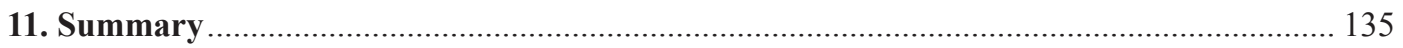

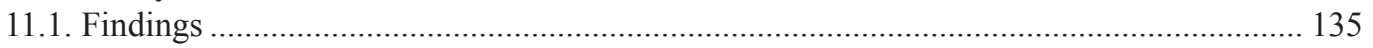

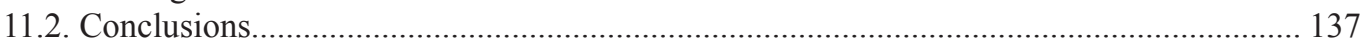

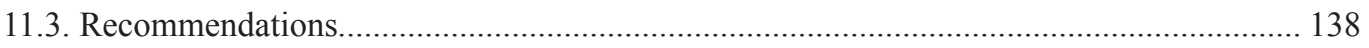

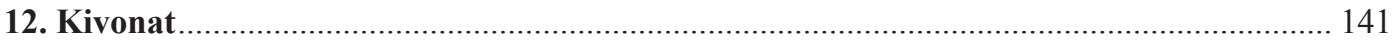

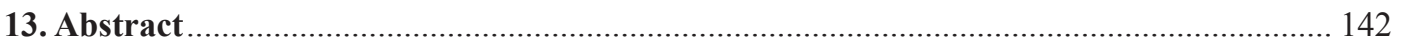

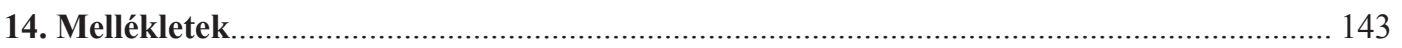

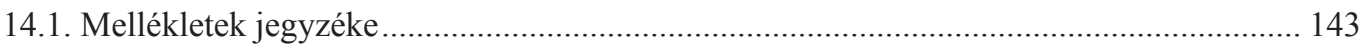

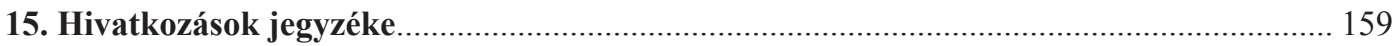





\section{Vezetői összefoglaló}

\section{Problémafelvetés}

A precíziós mezőgazdasági technológia használata Magyarországon jelenleg még nem általánosan elterjedt, azonban a helyspecifikus növénytermesztést alkalmazó termelök számának növekedése az utóbbi két-három évben felgyorsult. A helyspecifikus gazdálkodás a mezőgazdaságon belül azért éppen a szántóföldi növénytermesztésben növekszik elsősorban, mert az ágazat jövedelempozíciójából adódóan itt állnak rendelkezésre azok a források, amelyek az egyébként jelentős beruházási költségü technológia bevezetéséhez szükségesek. A precíziós gazdálkodás gyakorlata szorosan összekapcsolódik a talajkímélő és kisebb környezetterheléssel járó müvelésmódokkal.

Tanulmányunk célja a helyspecifikus gazdálkodás és a talajkímélő müvelés gazdasági eredményességre gyakorolt hatásának kimutatása. E cél érdekében a magyarországi tesztüzemi hálózat szántóföldi növénytermesztö üzemeinek bevonásával megvizsgáltuk a precíziós gazdálkodás magyarországi elterjedtségét, illetve felmértük az alkalmazott technológia színvonalát. A felmérés eredményei és a tesztüzemi rendszerben rendelkezésre álló adatok felhasználásával összehasonlító vizsgálatokat végeztünk a precíziós gazdálkodás elönyeinek/hátrányainak kimutatására a hozamváltozás, inputanyag-felhasználás, termelési érték, jövedelem és jövedelmezőség vonatkozásában.

\section{Módszer}

A precíziós gazdálkodás és talajkímélő müvelés elterjedtségének, valamint az alkalmazott technológia színvonalának felmérése érdekében primer adatgyüjtést végeztünk a tesztüzemi gazdaságok körében. A felmérés eredményeit összekapcsoltuk a gazdálkodási adatokkal és alternatív tesztüzemi kontrollcsoportok segítségével végeztünk összehasonlító vizsgálatokat a precíziós gazdálkodás előnyeinek/hátrányainak kimutatására a hozamváltozás, az inputanyag-felhasználás, a termelési érték, a jövedelem vonatkozásában. Mélyinterjúkat folytattunk a vizsgált mutatókat befolyásoló tényezők és a precíziós gazdálkodás általános sajátosságainak megismerése érdekében. Megvizsgáltuk a precíziós technológia alkalmazásához szükséges beruházások különböző intenzitási szintű bevezetésének megtérülését. Végül makrogazdasági becslést végeztünk a föbb szántóföldi ágazatok és azon gazdálkodói kör figyelembevételével, amelyek esetében igazolni tudtuk a precíziós gazdálkodás többletjövedelmezőségét.

\section{Eredmények}

A gazdálkodói percepciók kimutatása érdekében folytatott kérdőíves felmérés eredményei igazolták azt a hipotézisünket, hogy a termelők mindkét technológia terjedésének legnagyobb gátját a magas beruházás költségekben látják. A válaszadók szerint elterjedésüket leginkább az alkalmazás hatására realizálható magasabb jövedelmezőség segítené elö, de a termelők számára nyújtott több, illetve részletesebb információ is nagy jelentőséggel bírna, valamint ha a technológia alkalmazását valamilyen támogatási konstrukcióval is segítené az agrárirányítás.

A precíziós technológiát az első üzem (a válaszadók körében) 2004-ben kezdte el alkalmazni. A technológia terjedését kezdetben lassú felfutás jellemezte 2012-ig, azt követően lényegesen dinamikusabbá vált a folyamat. Általában véve az alkalmazott technológiai elemek közül a precíziós talajminta-vételezés, valamint a tápanyagkijuttatási terv készítése a leggyakoribb.

A precíziós növénytermesztő tesztüzemeknél a növénykultúrák között az őszi búza mind a művelt terület mérete (4161 hektár), mind a termesztők száma tekintetében élen jár a precíziós technológia alkalmazásában, majd azt követi a kukorica, a napraforgó és a repce. Míg a búzánál és a repcénél a tápanyag-utánpótlásban volt leginkább jellemző a precíziós technológia alkalmazása, addig a kukori- 
cánál és a napraforgónál a vetésben. A növények többségénél ez a két müveleti elem szerepelt az első két helyen, miközben a növényvédelemben és a talajművelésben már kisebb mértékben alkalmaztak precíziós technológiát, a betakarításban pedig elenyésző részben. Ez utóbbi alól csak a repce képez kivételt, a precíziós módon végzett betakarítás aránya 35,0 százalékot tett ki.

A talajkímélő művelés hatásai a megkérdezettek szerint korlátozottabbak a precíziós gazdálkodásénál. A hozam tekintetében a talajkímélő művelést végzők több mint egyharmada nem tapasztalt változást, 29,5 százaléka pedig kisebb mértékü növekedést figyelt meg, továbbá viszonylag sokan számoltak be a hozam kisebb mértékü csökkenéséről is.

A vizsgálatok eredményeit összegezve megállapítható, hogy átlagosan a búza hozamánál 7-17 százalékos, a kukoricáénál 2-9 százalékos, a napraforgónál 6-10 százalékos többletet eredményez a technológiaváltás, miközben a repcénél és az őszi árpánál nem sikerült a rendelkezésre álló adatok birtokában ilyen megállapítást tenni. A termelési érték tekintetében magasabbak az említett arányszámok, a búzánál 8-38 százalékos, a kukoricánál 11-42 százalékos, a napraforgónál 3-32 százalékos többletérték mutatkozik.

A többletértéket jellemző - esetenként széles - intervallumokat az magyarázza, hogy a precíziós technológia előnyei nagyban függenek az adott év időjárásától, illetve a talajadottságoktól, valamint a gazdálkodás színvonalától. A helyspecifikus gazdálkodás előnyei elsősorban a kedvezőtlenebb adottságú időszakokban és heterogén, kisebb és nagyobb termőképességü területeket egyaránt tartalmazó táblákon gazdálkodók esetében mutathatók ki, ahol a hagyományos mủveléssel a hozampotenciálhoz viszonyítva csak korlátozott eredmények érhetők el.

A precíziós technológia eredményes alkalmazásához nem elegendő a precíziós képességekkel rendelkező erő- és munkagépek beszerzése, illetve a megfelelő inputanyagok felhasználása. Nem homogén technológiáról van szó, amely bármely körülmények között ugyanúgy müködik, hanem az egyes technológiai müveleteket a helyi természeti adottságokhoz (pl. talajadottságok, domborzati viszonyok) szükséges adaptálni. A kívánatos eredmények eléréséhez komoly szakismeret szükséges (pl.: a termesztett növénykultúra tekintetében megfelelő elővetemény megválasztása), mindenképpen szaktanácsadás mellett javasolt a technológia bevezetése, hiszen a remélt előnyök megjelenése is csak a technológia megfelelő alkalmazását követően várható.

A precízebb technológia, a ráfedés- és kihagyásmentes múvelés eredményeként általában véve azt várnánk, hogy az áttéréssel csökken az inputfelhasználással összefüggő költség. Vizsgálataink ennek éppen az ellenkezőjét támasztották alá, a hozamokhoz hasonlóan az inputfelhasználáshoz köthető költségek szintjében is jellemzően többlet mutatkozott. A búzánál -3 és +47 százalék, a kukoricánál -5 és +30 százalék, a napraforgónál -8 és +26 százalék között változott az egy hektárra vetített termelési költség a hagyományos technológiához képest. Ennek a szakirodalommal egyébként összecsengő megállapításnak a magyarázata az, hogy Magyarországon az inputfelhasználás szintje egyébként is jellemzően alacsony, így a modern művelési módra való áttéréssel a kívánatos hozamok elérése érdekében az inputfelhasználás intenzitását növelni szükséges. Ezen felül megfigyelhető, hogy a fajtaválasztás során előtérbe kerülnek értékesebb, magasabb genetikai potenciával bíró fajták, amelyek gyakran magasabb költséget eredményeznek. Ez egyben azt is jelenti, hogy az inputforgalmazóknak is érdeke a technológia terjesztése.

A nagyobb inputfelhasználás és a környezeti fenntarthatóság nem áll ellentétben egymással, ugyanis precíziós kijuttatással (a megfelelő inputot a megfelelő kultúrának, a megfelelő időpontban és fizikai helyen) a tápanyagot a növény nagyobb valószínűséggel képes felvenni és hasznosítani, ezáltal környezeti károsodás nélkül folyhat a termelés. Ezt figyelembe véve a precíziós gazdaságok számára érdemi termelési korlátozást nem okozva is lehetséges a környezetterhelési határértékek szigorítása, amely többletteljesítményt viszont szükséges valamilyen formában elismerni. 
A búzánál és a napraforgónál vizsgálataink szerint egyértelmüen nőtt az átlagos ágazati jövedelmezőség, előbbinél 23-123 százalékos többlet, utóbbinál 28-52 százalékkal nagyobb eredmény realizálható. A kukoricánál nem minden kontrollcsoporthoz képest mutatható ki jövedelemnövekedés, így itt előfordulhat akár 17 százalékos kiesés, de akár 105 százalékkal magasabb jövedelem is.

A rendelkezésünkre álló adatok birtokában ágazati szinten becsléseket végeztünk a precíziós tevékenységre való áttérés makroszintű hatásaira. Megnéztük, hogy hogyan alakul ágazati szinten a hozam, a termelési érték, a termelési költség és az eredmény, amennyiben a vizsgált eredményesen áttérő üzemekhez hasonló paraméterekkel (termelési költség, vetésterület mérete) bíró gazdaságok végrehajtják a technológiaváltást.

A kiválasztott üzemek áttérésével a jövőbeni precíziós területek a vizsgálatba vont főbb szántóföldi növények teljes 2,9 millió hektárnyi vetésterületéből 1,4 millió hektárt, azaz 46,9 százalékot tennének ki. A búza esetében a precíziós területek a teljes búzatermő terület 59 százalékát, kukoricánál a teljes kukoricatermő terület 40 százalékát, napraforgónál a teljes napraforgó-terület 38 százalékát jelentenék. Az őszi árpa és őszi káposztarepce precíziós technológiával művelt területe külön-külön 15-17 százalékát adná a két ágazat összes vetésterületének.

A precíziós gazdálkodást választó több mint 21 ezer üzem átlagosan 2,4 százalékkal nagyobb (+342,7-858,9 ezer tonna) termésmennyiséget produkálna a vizsgált növényeknél az országos 14,3 millió tonna termésmennyiséghez képest. A termelési érték az öt növénykultúránál együttesen a jelenlegit 32,0-142,0 milliárd forinttal múlná felül, azaz az értékük 826,2-936,2 milliárd forintot jelentene.

A termelési költségek összességében 606,2 milliárd forintról 10,4 milliárd forinttal 595,9 milliárd forintra csökkennének, amennyiben az általunk kiválasztott üzemek precíziós gazdálkodásra váltanának. Ezen belül a vetömagköltség 2,4 milliárd forinttal csökkenne, a mütrágyaköltség 3,8 milliárd forinttal emelkedne, a növényvédőszer-költség 1,8 milliárd forinttal mérséklődne.

Az ágazati eredmény a precíziós gazdálkodásra váltók esetében jelentősen, 15,2-88,5 milliárd forinttal bővülne, azaz 187,9 milliárd forintról 203,1-276,4 milliárd forintra emelkedne.

Végezetül azt is megvizsgáltuk, hogy hogyan alakulna a beruházási költség megtérülése a technológiát váltó üzemeknél. Az eszközállomány elhasználódottsága alapján egyes üzemeknél komplett gépparkcserét feltételeztünk, másoknál a precíziós eszközökkel való felszerelést láttuk indokoltnak, megint másoknál szerkezeti elemek és precíziós szoftverek beszerzését. A beruházási költség a három kategóriában együttesen mintegy 325 milliárd forint lehetne, melynek legnagyobb részét (mintegy 300 milliárd forintot) a teljes gépparkcsere adná.

Számításaink igazolták, hogy a gazdálkodóknak - az 1000 ha alatti és feletti területtel rendelkezőknek egyaránt - mind a szerkezeti elemekkel és szoftverekkel történő felszerelés, mind pedig a precíziós eszközökkel való felszerelés megéri, mert annak költsége bőven megtérül a technológia eredményeként keletkezö többletjövedelmekben. A megtérülés egyedül a teljes gépparkcserénél nem igazolódott. Ennek kapcsán azonban meg kell jegyezni, hogy mivel a gépek az üzem teljes területén használatosak, illetve nem csak a többleteredmények elérésében játszanak szerepet, így nem is várható a beruházási költségüknek a precíziós többletjövedelmekben való megtérülése. Ugyanezen üzemeknél a precíziós eszközökkel való felszerelés már gazdaságosnak bizonyult.

A tanulmány egyik fontos erénye, hogy a precíziós technológia előnyeit a Közös Agrárpolitika gazdasági hatásainak bemutatására használt, ötvenéves múltra visszatekintő FADN-adatbázis adatainak felhasználásával bizonyítottuk. Ez lényeges elem úgy szakpolitikai szempontból, mint a termelői döntéshozatal oldaláról, mivel a tesztüzemi rendszer üzemei olyan mintaként tekinthetők, amely megfelelően képes reprezentálni a meghatározó árutermelő gazdálkodókat. 
A technológia elterjedésének legfőbb gátjaként a megkérdezett tesztüzemi precíziós gazdálkodók a jelentős beruházásigényt és az ehhez kapcsolható pénzügyi nehézségeket azonosították. Ezt követte a tudás, az ismeretek hiánya, illetve az új ismeretek elsajátításától való félelem. Ennek jelentőségét jól mutatja, hogy a technológia elterjedését támogató tényezők között az információk, ismeretek megosztása a többletjövedelem mellett másodikként szerepelt a válaszok száma alapján. A megfelelő ismeretek, a technológia biztos kezelésének képessége a mélyinterjúkban is kulcstényezőként szerepelt a precíziós technológia sikeres alkalmazásának kritériumai között. Figyelembe véve a technológia által realizálható makrogazdasági hatásokat, úgymint a többlettermés, a többlethozam és -jövedelem, a precíziós technológia elterjedését az agrárirányításnak is érdemes volna prioritásként kezelnie.

Ennek megfelelően javasolt a mezőgazdasági szakiskolák és az agrárképzést is nyújtó egyetemek oktatóinak képzése piaci szolgáltatást nyújtó precíziós szaktanácsadók által. Fontos a szakiskolák és az egyetemek felszerelése a precíziós gazdálkodásra alkalmas gépekkel és szoftverekkel, amelyek működtetéséhez szintén igénybe kell venni a piaci precíziós szaktanácsadási segítséget. Tovább szükséges erősíteni a duális képzést, ahol kiemelt szerepet kell kapjanak a precíziós gazdálkodást végző termelök.

Nemzeti forrásból elkülönített alapot kell biztosítani a precíziós gazdálkodással foglalkozó, azt témájául választó alap- és alkalmazott kutatási témáknak, mely utóbbiak esetében törekedni kell a technológiát a gyakorlatban használó kulcsszereplők (termelők, szaktanácsadók, gépgyártók, informatikai vállalkozások) szoros bevonására. Ezáltal biztosítható, hogy a kutatási források gyakorlati problémák megoldását segítsék elő, és a hazai agrár- és gépipari, valamint informatikai vállalkozások növekedésnek indulva képesek legyenek betörni a jövőben várhatóan drasztikusan bővülö, a mezőgazdasági digitalizációhoz köthető réspiacokra.

Jogszabályi háttérrel szükséges biztosítani a precíziós gazdálkodás minél zökkenőmentesebb fejlődését. Ezen belül célszerü biztosítani, hogy a precíziós gazdálkodás során keletkező adatállományokról a termelők rendelkezhessenek, azokat a gépgyártóktól, illetve az adatok rögzítőitől megkaphassák és ezáltal hazai kutatási célokra is fel lehessen használni. A modern technológiák életszerü használatát (pl.: drónok, pilóta nélküli repülők repülésének engedélyezése) lehetővé kell tenni, illetve szükséges a technológia alapját képező talajminta-vételezés precíziós helymeghatározása és külső szakértő általi validálása. Meg kell oldani az állami adatbázisokban tárolt termelői, valamint táblaszintű adatok jogosultságkezelését (pl.: örökös, vevő vagy új bérlő hozzáférhessen a tábla korábbi adataihoz).

Amennyiben a hazai és/vagy az uniós támogatási rendszer - szubvenciók vagy akár visszatérítendő támogatás, kamattámogatott hitel formájában - forrást biztosítana a gazdák számára a precíziós technológiai elemek adaptálására, a helyspecifikus módon végzett gazdálkodás rohamos terjedésnek indulna Magyarországon. Mivel a precíziós gazdálkodás hozzájárul a környezeti fenntarthatósághoz, akár a Vidékfejlesztési Program Agrár-környezetgazdálkodási Programján keresztül is igényelhetnének a gazdálkodók a technológia bevezetéséhez szükséges forrást.

A kérdőíves felmérések, valamint a kapcsolódó vizsgálatok megismétlése szükségszerü néhány éven belül, hiszen a technológiát bevezető üzemek száma folyamatosan nő, illetve az alkalmazás „mélysége” is várhatóan javul. A jelenlegi kutatási eredmények a technológia felfutási szakaszában keletkeztek, így könnyen elöfordulhat, hogy néhány év múlva markánsabb hatások mutathatók ki. 


\section{Rövidítések jegyzéke}

CAN-bus (Controller Area Network) - A járművek különböző szabályozó egységeit összekötő hálózat. Segítségével gépüzemeltetési adatok gyüjthetők.

CEMA (Comité Européen du machinisme agricole, European Agricultural Machinery Association) - Európai Mezőgazdasági Gépforgalmazók Szövetsége.

DGPS (Differential Global Positioning System) - Differenciális GPS-rendszer. Földi referenciaállomások segítségével korrigálja a müholdas GPS mérési hibáit.

EC (Electrical Conductivity) - Elektromos vezetőképesség. A talaj elektromos vezetőképessége alapján - nem szikes talajok esetén - következtetni lehet a talajok összetételére, tömörödöttségére és a szervesanyag-tartalomra.

EGNOS (European Geostationary Navigation Overlay System) - A GPS navigációs rendszer szolgáltatásait kiegészítő európai rendszer. Az ingyenes korrekciós jelekkel 1-2 méteres viszszatérési pontosság és 20-30 centiméteres csatlakozási pontosság érhető el.

EIP-AGRI (European Innovation Partnership for Agricultural Productivity and Sustainability) - A mezőgazdaság termelékenységét és fenntarthatóságát célzó Európai Innovációs Partnerség.

FADN (Farm Accountancy Data Network) - A mezőgazdasági üzemek pénzügyi, vagyoni helyzetét felmérő európai uniós reprezentatív információs rendszer. Magyarországi alrendszere az Agrárgazdasági Kutató Intézetben készített tesztüzemi rendszer.

FÖMI - Földmérési és Távérzékelési Intézet. (Jelenleg: Budapest Főváros Kormányhivatala, Földmérési, Távérzékelési és Földhivatali Főosztály)

GNSS (Global Navigation Satellite System) - Globális navigációs müholdrendszer, amely az amerikai GPS, az orosz GLONASS, az európai Galileo és a kínai Compass rendszerek közös elnevezése. A GNSS-infrastruktúrához sorolják azokat a földi vagy műholdas kiegészítő rendszereket is, amelyek a nagyobb pontosságú helymeghatározást segítik (korrekciós jelek).

GOFR-növények - Gabonafélék, olaj-, fehérje- és rostnövények.

GPS (Global Positioning System) - Globális helymeghatározó rendszer. Az USA Védelmi Minisztériuma által fejlesztett és üzemeltetett, időjárástól és napszaktól függetlenül müködő müholdas helymeghatározó rendszer, ami háromdimenziós helymeghatározást tesz lehetővé. A hétköznapi szóhasználatban általánosan a müholdas helymeghatározásra utal.

ISOBUS (ISO Binary Unit System) - Lehetővé teszi a különböző szenzorok, az adatfeldolgozó és vezérlőegységek közötti szabványos adatcserét. Ezáltal egyetlen univerzális terminállal megoldható bármelyik gyártó ISOBUS-t támogató eszközének ellenőrzése és vezérlése. A protokoll alapját a nemzetközi ISO 11783 szabvány (Tractors and machinery for agriculture and forestry - Serial control and communications data network) írja le.

IVSZ - Informatikai, Távközlési és Elektronikai Vállalkozások Szövetsége.

JD SF-1 - A John Deere StarFire antennához biztosított ingyenes korrekció, ami egy méter körüli visszatérési és 30 centiméteres csatlakozási pontosságot biztosít.

JD SF-2 - A John Deere fizetős StarFire korrekciós jele, ami 10-15 centiméteres csatlakozási pontosságot biztosít.

LIDAR (Light Detection and Ranging) - Lézeralapú távérzékelés. Alkalmazható többek közt távolságmérésre, a vizsgált objektumról háromdimenziós modell készítésére, légköri vizsgálatokra. 
NDVI (Normalized Difference Vegetation Index) - Normalizált differenciál vegetációs index. A növényzet állapotának jellemzésére szolgál, számítási módja: $N D V I=(N I R-R) /(N I R+R)$, ahol NIR a közeli infravörös és $R$ a látható vörös tartományban mért visszaverődés.

QR-kód (Quick Response-kód) - Kétdimenziós vonalkód. Csak számokból max. 7089, alfanumerikus karakterekből 4296, bináris adatokból 2953 bájtnyit képes tárolni. Ingyenesen felhasználható nyílt szabványon alapszik. Értelmezéséhez szükség van valamilyen kamerával rendelkező eszközre (lehet mobiltelefon vagy tablet is) és egy QR-kód-olvasó alkalmazásra. Több weboldalon ingyenesen generálhatók QR-kódok.

RFID (Radio Frequency IDentification) - Rádiófrekvenciás azonosítás. Az automatikus azonosításhoz és adatközléshez használt technológia, melynek alapja a rádiófrekvenciás adóvevő egység kommunikációja a megfigyelt objektumokon elhelyezett RFID-címkével. Az RFIDcímke (más néven tag) egy apró tárgy, amely rögzíthető vagy beépíthető az azonosítani kívánt objektumba.

RTK (Real Time Kinematik) - Korrekciós jelek alkalmazásával elérhető $\pm 2 \mathrm{~cm}$ pontosságú, valós idejü helymeghatározás mozgó jármủveknél. A korrekció alapulhat egy ismert bázisállomás vagy több referenciavevő együttes adatainak figyelembevételén (hálózatos RTK). A korrekciós jel továbbítása - az alkalmazott technológiától függően - rádiófrekvencián (URH) vagy internet és mobil távközlési eszközök segítségével történik.

USDA (United States Department of Agriculture) - Az USA mezőgazdasági minisztériuma.

UAV (Unmanned Aerial Vehicle) - Pilóta nélküli légi jármü, gyakran a „drón” kifejezést használják rá. Kialakítása lehet repülőgépszerü vagy több rotorral ellátott multikopter. Ön- vagy távirányítással (leggyakrabban a kettő kombinációjával) rendelkezik. Kamerával felszerelve használható a területek állapotának felmérésében (árvíz, belvíz, biomassza, vadkár stb.).

VRA (Variable Rate Application) - Változó mennyiségü (differenciált) kijuttatás. A tábla eltérő adottságú területeinek megfelelően változó mennyiségü mütrágya, növényvédő szer, öntözővíz vagy vetőmag kijuttatása.

VRT (Variable Rate Technology) - Változó (differenciált) kijuttatási technológia. Azok a technológiai megoldások, melyek lehetővé teszik a kijuttatott anyagok mennyiségének és/vagy összetételének menet közbeni változtatását.

WSN (Wireless Sensor Network) - Vezeték nélküli szenzorhálózat. A mezőgazdasági területeken (szántóföld, ültetvény, üvegház) vagy állattartó telepeken használt különböző adatgyüjtő egységek összekapcsolása vezeték nélküli hálózaton keresztül. A párhuzamosan gyüjtött környezeti adatok egy központi szerverre továbbíthatók. 


\section{Bevezetés}

Az informatika a világ egyik leggyorsabban fejlődő iparága, amely technológiai fejlődés hatásai a mezőgazdaság digitalizációjában is lecsapódnak. Ennek eredménye a precíziós mezőgazdaság. A precíziós technológia Magyarországon jelenleg még nem általánosan elterjedt, azonban a helyspecifikus gazdálkodást alkalmazó termelők számának növekedése az utóbbi két-három évben felgyorsult.

A helyspecifikus gazdálkodás a mezőgazdaságon belül a szántóföldi növénytermesztésben terjedt el elsősorban, mivel az ágazat jövedelempozíciójából adódóan itt álltak rendelkezésre azok a források, amelyek az egyébként költséges technológia bevezetéséhez szükségesek. A növénytermesztésben ma már a termelés minden eleménél, a vetést megelöző talaj-előkészítéstől a betakarításig, a tarlóápolás mủveletéig mindenhol alkalmazható a precíziós mủvelés.

A talaj növénytermesztésben betöltött kiemelt fontossága okán és a környezettudatosság jegyében a precíziós gazdálkodással párhuzamosan a talajkímélő müvelés elterjedése is növekszik, amelynek célja a talaj megfelelő állapotának megteremtése és/vagy fenntartása. A precíziós gazdálkodás és a talajkímélő művelés a gyakorlatban gyakran egymást kiegészítő megközelítést jelent, mindkettő igényli az innovatív gazdálkodói hozzáállást. Így a gyakorlatban az a jellemző, hogy az újdonságok iránt fogékony gazdálkodók mindkettő alkalmazásával foglalkoznak.

Általános vélemény, hogy a precíziós gazdálkodási forma nagyon hasznos, hiszen az egyszerre járhat a jövedelmek növelésével és az okszerübb gazdálkodás révén a környezetterhelés mérséklésével is. A természeti adottságoknak való jobb megfelelés, a hatékonyabb termelés és kisebb környezetterhelés okán a precíziós gazdálkodás olyan kihívásokra jelenthet választ, mint például a klímaváltozás, a természeti erőforrások szükössége, a növekvő népesség nagyobb élelmiszerigénye és a fenntarthatóság.

Az agrárszakma művelőinek többsége egyetért abban, hogy a növénytermesztés számára ez jelenti a jövőt. Szakirodalmi források széles köre számol be a technológia hazai alkalmazásának számszerü előnyeiről a hozamok és inputok tekintetében, azonban a jövedelemre, jövedelmezőségre gyakorolt hatásokról viszonylag kevés szó esik. Ez azzal magyarázható, hogy a térbeli különbözőségek (eltérő talajadottságok, domborzati viszonyok, táblaméret stb.), illetve évente változó időjárási viszonyok miatt mind a térbeli, mind pedig az időbeli összehasonlítás nehézkes, kizárólag a technológiának tulajdonítható hasznokat rendkívül nehéz kimutatni. Másik jellemzője a szakirodalomban megjelent tanulmányoknak, hogy azok a helyspecifikus gazdálkodás elönyeit többnyire csak egy-egy üzemre vagy egy-egy táblára korlátozva ismertetik.

Tanulmányunk végső célja a helyspecifikus gazdálkodás, valamint a talajkímélő művelés termelés eredményességére gyakorolt hatásának számszerüsítése. E cél érdekében első lépésként primer adatgyüjtést végeztünk a tesztüzemi gazdaságok körében a két gazdálkodási forma magyarországi elterjedtségének, illetve az alkalmazott technológia színvonalának felmérése céljából. Második lépésként a felmérés eredményeit a gazdálkodási adatokkal kapcsoltuk össze, különböző szempontok alapján a precíziós üzemekhez hasonlító kontrollcsoportokat képeztünk és ily módon végeztünk összehasonlító vizsgálatokat a technológia előnyeinek/hátrányainak kimutatására a hozamváltozás, inputanyagfelhasználás, termelési érték, jövedelem vonatkozásában. Ezen túlmenően a részletesebb ismeretek megszerzése érdekében néhány mintaüzemben termelői mélyinterjút készítettünk. A makroszintü hatások feltárása céljából beruházásmegtérülési és ágazati szintü becsléseket végeztünk.

A kutatás során a következő hipotéziseket fogalmaztuk meg:

- A precíziós szántóföldi gazdálkodás magyarországi elterjedésének legfontosabb hátráltató tényezői a magas beruházási költség, a megfelelő termelői információ- és a szaktanácsadás hiánya. 
- A precíziós szántóföldi gazdálkodás a fő növénykultúráknál (őszi búza, kukorica, őszi káposztarepce, napraforgó, őszi árpa) egyértelmű többlethozammal, költségelőnnyel és jövedelmezőségi előnnyel rendelkezik az általánosan jellemző (átlagos) müveléshez képest.

- A precíziós szántóföldi gazdálkodás egyértelmüen kisebb környezetterhelést (fajlagos inputfelhasználást) eredményez, mint a hagyományos müvelés.

- A precíziós szántóföldi gazdálkodás általános használata nemzetgazdasági szinten is kisebb inputanyagimportot és magasabb hazai élőmunka-lekötést eredményezne.

A tanulmány első fejezetében a helyspecifikus gazdálkodással és talajkímélő műveléssel összefüggésben felmerülö fogalmak tartalmát tisztázzuk. Az elméleti részben a szántóföldi növénytermesztés mellett külön kitérünk a precíziós technológia kertészetben és szölészetben, illetve állattenyésztésben való alkalmazásának sajátosságaira. Idegen nyelvü és hazai szakirodalom alapján képet adunk a technológia nemzetközi és magyarországi elterjedtségéről. Ezt követően bemutatásra kerül, hogy a helyspecifikus gazdálkodásnak köszönhetően milyen előnyökre és hátrányokra, megtakarításokra és többletráfordításokra számíthatnak a gazdálkodók. Végül egy valószínűsíthető elterjedés alapján becslést készítünk az áttérés makroszintű hatásairól.

A szakirodalom részletes ismertetését követően áttérünk az általunk végzett vizsgálatok eredményeinek bemutatására. A 4. fejezetben a részletes módszertani lépések szerepelnek, az 5 . fejezetben pedig a kérdőíves felmérés eredményeit ismertetjük a precíziós gazdálkodás és a talajkímélő müvelés magyarországi elterjedtségére és alkalmazásuk sajátosságaira vonatkozóan. Majd a technológiáktól elméletileg várható előnyök bemutatása következik a KITE Zrt. adatai alapján, illetve - előbbieket mintegy szembeállítva a gyakorlattal - a mélyinterjún részt vett vállalkozások eredményeinek, tapasztalatainak ismertetése. A 7. fejezetben részletesen ismertetjük a kérdőíves felmérés tesztüzemi rendszerrel való összekapcsolása és kontrollcsoportos összehasonlítás révén elvégezhető vizsgálatok eredményeit, amelyeket azután ágazati szintre emelve becsléseket végeztünk a makroszintủ hatásokat illetően. Végül az utolsó fejezetben a technológia terjedését akadályozó tényezőket gyűjtöttük össze, illetve javaslatokat fogalmaztunk meg azok elhárítására. 


\section{A precíziós és a talajkímélő gazdálkodás fogalma és tartalma}

Az Európai Unió Közös Agrárpolitikája nagy hangsúlyt fektet arra, hogy a termelékenység növelése a környezet minél kisebb károsítása mellett valósuljon meg, ezért ösztönözi a fenntarthatóságra törekvő, innovatív megoldások alkalmazását.

A fenntarthatóság szempontjából kiemelt jelentőségű a talajok állapota. Európában a földhasználat és egyes mezőgazdasági művelési gyakorlatok fokozott talajromláshoz - szerves anyag csökkenése, erózió, talaj tömörödése, savanyodás - és a talajok csökkenő funkcióképességéhez vezettek.

A fenntartható mezőgazdaság alternatíváit elemző EU-s tanulmány (Underwood et al., 2013) a lehetőségek közül kiemeli a precíziós gazdálkodás, a talajkímélő (talajvédő) mezőgazdaság, a vegyes gazdálkodási rendszerek, a biogazdálkodás, valamint az agrárerdészet rendszerében rejlő lehetőségeket.

Munkánk során az első két rendszer hazai helyzetét vizsgáltuk, ezért az alábbiakban ezek jellemzőit foglaljuk össze.

\subsection{Precíziós gazdálkodás meghatározása, jellemzői}

A precíziós gazdálkodás vagy precíziós mezőgazdaság kifejezés (angolul Precision Farming vagy Precision Agriculture) alatt kezdetben csak a szántóföldi növénytermesztést értették, jelenleg azonban már a kertészeti alkalmazásokat (Precision Horticulture, P. Viticulture), valamint a precíziós állattenyésztést ( $P$. Livestock Farming) is magában foglalja.

A precíziós gazdálkodás egyik fő jellemzője, hogy a gazdálkodás minden szakaszában - adatgyüjtés, adatfeldolgozás, döntéshozatal, beavatkozás - kiemelt szerepet kapnak az infokommunikációs technológiák, a pontos mérések, a szabályozás és a számítógépes vezérlés. Tamás (2002) megfogalmazásában a precíziós mezőgazdaság az információs társadalomnak a mezőgazdasági szakterületen való leképeződése.

Másik meghatározó jellemzője, hogy figyelembe veszi az adott termelési egységen belüli eltérő körülményeket és azok alapján határozza meg a kezelések jellemzőit. A kezelési egységek mérete a növénytermesztésben néhány hektártól akár egy-egy növényig változhat (Blackmore és Griepentrog, 2002), állattenyésztés esetén pedig egy épülettől egy állatig.

A precíziós állattenyésztés magában foglalja az állatok valós idejü monitorozását, az így összegyüjtött adatok feldolgozását és ez alapján a differenciált ellátást. Magyarországon leginkább a sertés- és baromfitartóknál terjedt el a számítógépes takarmánykiosztás, illetve tejtermelőknél fordul elő egyedi takarmányozás, amivel javítható a takarmányhasznosítás és magasabb növekedési ráta érhető el. A precíziós technikák azonban számos más területen is jól hasznosíthatók. Folyamatosan és automatikusan nyomon követhető a termelés és szaporodás, az állatjólét, valamint az állattartás környezetre gyakorolt hatása. Az állatok viselkedésének vizsgálatával korán felismerhetők a sérülések, megbetegedések, így csökkenthetök a költséges állatorvosi beavatkozások (Banhazi et al., 2012; Berckmans, 2014).

Jelen tanulmány a szántóföldi növénytermesztésre fókuszál, az állattenyésztésben és más növénytermesztési ágazatokban alkalmazott módszerekre csak a teljesség kedvéért térünk ki.

A precíziós növénytermesztés olyan műszaki, informatikai és termesztéstechnológiai alkalmazások összessége, amelyek lehetővé teszik a táblán belül változó körülményeknek megfelelő müvelést, ezáltal hatékonyabbá teszik a termelést, csökkentik az inputanyagok felhasználását, valamint a feleslegesen kijuttatott szerek csökkentésével segítik a környezetkímélő gazdálkodást (Győrffy, 2000; Stombaugh et al., 2001; EIP-AGRI, 2015). 
A precíziós gazdálkodás a speciális gépek és az informatikai háttér miatt is nagy beruházásigényü, ugyanakkor nem szükséges minden elemét egyszerre bevezetni, lehetőség van a hagyományos gazdálkodás és a teljesen precíziós megoldásokra alapozott rendszer közötti fokozatos átállásra.

A leggyakrabban használt szinonimái egyes részfunkciókat emelnek ki, például

- helyspecifikus gazdálkodás (site specific production);

- termőhelyhez alkalmazkodó technológia (site specific technology);

- térben változó technológia (spatial variable technology);

- változtatható/differenciált kijuttatási technológia (variable rate technology).

A tanulmányban a helyspecifikus gazdálkodás kifejezést a precíziós gazdálkodás szinonimájaként használjuk.

A különböző szenzorok adatainak összekapcsolása és az automatizálás növekedése miatt újabb publikációkban megjelent az okos gazdálkodás (smart farming) fogalma is, amelyet néhányan már a precíziós mezőgazdaság szinonimájaként használnak (Romeo, 2016), mások inkább a következő lépésnek tartják (AIOTI, 2015).

A gazdasági célok mellett a precíziós gazdálkodás társadalmi célokat is szolgál, egyrészt a növekvő élelmiszer-minőség és -biztonság, másrészt a csökkenő környezetterhelés révén (EIP-AGRI, 2015; Takácsné György, 2011).

A technológia sikeres alkalmazásához azonban nem elég a technikai háttér biztosítása, szükséges a gazdálkodó és a technológiában érintett személyek szemléletváltása, szaktudása és legtöbb esetben a szaktanácsadói háttér igénybevétele.

A precíziós gazdálkodók számára készített szoftverek lehetővé teszik az elvégzett munkák dokumentálását is. Ezek segítségével a munkavégzés közben rögzített adatok automatikusan bekerülnek a táblatörzskönyvbe vagy gazdálkodási naplóba, könnyen integrálhatók egy vezetői információs rendszerbe.

\subsection{A precíziós növénytermesztés technikai háttere}

\subsubsection{Helymeghatározás}

A térbeli változatosságot figyelembe vevő művelésmódot csak akkor lehet megvalósítani, ha megfelelő helymeghatározó rendszer is rendelkezésre áll. A lézer, mikrohullám, illetve rádióhullámok alkalmazásával végzett kísérletek után a müholdas helymeghatározó rendszer (Global Positioning System, GPS) megjelenése volt kiemelt jelentőségű az 1990-es években (Stafford és Ambler, 1994).

A rendszer használatának elterjedését nagyban elősegítette, hogy Bill Clinton 2000-ben megszüntette a polgári felhasználású kód további zavarását, az úgynevezett Selective Availability technikát, így a valós idejü helymeghatározás pontossága 20 m körülire csökkent (Tamás, 2002). A 2000-es évektől a globális navigációs müholdrendszerek (Global Navigation Satellite System, GNSS) és az ezekre épülő korrekciós szolgáltatások használata tette általánossá a műholdas helymeghatározást és a jármüvek navigációját (Ádám, 2007).

A GPS adott időközönként meghatározza az aktuális pozíciót és lehetővé teszi a terület térbeli változékonyságának rögzítését, ezáltal a mezőgazdasági táblákról a korábbiaknál sokkal részletesebb adatbázis állítható elő (Neményi et al., 2003).

A helymeghatározás pontossága több tényezőtől függ: az eszköztől (jelvevő), a vevő által „látott” müholdak számától, a mérési módszertől és az alkalmazott korrekciós eljárásoktól. A hétköznapi életben használt, néhány méter pontosságú navigációs GPS a helyspecifikus gazdálkodásban nagyon 
korlátozottan használható. A pontossággal azonban nő a költség, ezért érdemes megfontolni, hogy milyen szintet szükséges alkalmazni (Milics és Tamás, 2007).

Betakarítás, mütrágyázás, növényvédelem esetén megfelelö lehet a deciméteres csatlakozási pontosság, ilyen megoldást nyújt az EGNOS (20-30 cm), az OmniStar (10-15 cm), a JD SF-1 (30 cm) és a JD SF-2 $(10-15 \mathrm{~cm})$ korrekció alkalmazása.

Több mủvelet, például vetés vagy kultivátorozás esetén azonban elengedhetetlen a néhány centiméteres pontosság, ami a valós idejü kinematikus (Real Time Kinematic, RTK) rendszerek alkalmazásával érhető el. Ilyen szolgáltatást (kb. $2 \mathrm{~cm}$ pontosság) nyújt a gazdálkodók számára Magyarországon a Földmérési és Távérzékelési Intézet GNSSnet.hu hálózata (FarmRTK), a Geotrade GNSS, az AXIÁL mAXI-NET, a KITE RTK, valamint az Agromatic RTK-mindenkiNET és AgroVRS rendszere.

Viszonylag szük körzetben (10-15 km) hasonló pontosság érhető el saját RTK-bázisállomás használatával is, de a bázisállomástól távolodva a helymeghatározás pontossága csökken. Riczu et al. (2012) vizsgálatai azonban azt mutatták, hogy a hálózati RTK-korrekció teljesítménye még ennél kisebb távolságon belül is felülmúlta a saját bázisállomás jelét.

Lejtős terep esetén a helyes terepi pozíció meghatározásához szükség van dőléskompenzáció használatára is.

\subsubsection{A jármü-navigáció segítése}

A tervezett útvonal követéséhez és a sorok megfelelö csatlakoztatásához a sorvezető, kormányautomatika, illetve robotpilóta alkalmazása ad segítséget. Pontosságuk és felhasználási lehetőségeik elsősorban az előző részben ismertetett GPS-korrekcióktól függ. A navigációs rendszerek segítségével az egymás melletti sorok nagy pontossággal követhetők, minimális ráállási hibával. Így a munka során csökkenthető az átfedés, az elhasznált üzemanyag, a feleslegesen kijuttatott vetőmag, műtrágya vagy növényvédő szer. A nagy pontosságú (RTK) helymeghatározó rendszerrel felszerelt munkagépek évről évre néhány cm pontosan ugyanazt a nyomvonalat tudják végigjárni (Nagy, 2012). Megkönnyítik a munkát rossz látási körülmények, például köd, porfelhő vagy sötét esetén.

A sorvezető nem helyettesíti, csak megkönnyíti a vezető munkáját. A kijelzők méretükben és a soron tartás jelzésében is eltérők. Elterjedt a LED-sor használata, mely minden napszakban jól látható és egyszerüen ellenőrizhető - amíg a soron van a gép, addig a középső részen zöld fénnyel világít, a sortól való eltérés esetén a LED-sor szélei felé piros színnel jelez. A sorvezetők több funkcióval is rendelkezhetnek, például egyenes és görbe vonal követése, megjelölt ponthoz navigálás, lefedési minta megjelenítése, a megművelt terület mérése, munkavégzési napló rögzítése, szakaszvezérlés.

Az automatikus kormányzás még több koncentrációs terhet vesz le a gépkezelő válláról, mert ez esetben a kormányautomatika tartja a megfelelő nyomvonalon a gépet például a kormányoszlopba épített elektromotorral. Több gépforgalmazónál a kormányautomatika már a megrendeléskor kérhetö, de utólag is beépíthető.

Robotpilóta alkalmazása esetén a hidraulikus kormányrendszerbe épített vezérlőszeleppel történik a kormányzás irányítása. A nagy gyártók modern gépeiben ez a szelep alapkivitelben megtalálható, régebbi, de már hidraulikus kormányrendszerrel rendelkező gépekbe utólag beépíthető. A robotpilóták előnye a kormányautomatikával szemben, hogy sokkal gyorsabban képesek reagálni a korrekciós jelekre, és ebből adódóan pontosabban tartják a kijelölt nyomvonalat (Farkas, 2015). Az ilyen berendezések alkalmazását leginkább a $2 \mathrm{~cm}$ pontosságú RTK navigációs rendszerhez ajánlják.

Vannak olyan robotpilóta-rendszerek, amelyek a traktorok mellett a munkagépeket is képesek irányítani. A passzív munkagépkormányzásnál a munkagépre szerelt GPS-ből érkező adatok alapján korrigálja az erőgép kormányzását a rendszer, szükség esetén az erőgépet eltéríti a saját nyomvonalá- 
tól annak érdekében, hogy a munkagépet a megfelelő nyomon tartsa. Az aktív munkagépkormányzás egymástól függetlenül, aktívan kormányozza az erőgépet és a munkagépet, így mindkettő pontosan a kívánt nyomon halad.

A jármü-navigáció új lehetősége a távfelügyelet, amikor csak az első vezérgépen van vezető, a mögötte haladó gép(ek) haladását pedig távfelügyelettel ellenőrzi.

Kombájnok esetén alkalmazzák a lézeres sorkövetőt is, ami képes megkülönböztetni a már levágott és a még lábon álló terményt, így hozza létre a pontos jelet a kormányzáshoz. Kultivátorozásnál terjed a szenzorvezérelt technológia, amikor a kultivátorra szerelt optikai szenzor végzi a növénysorok azonosítását és követését.

A jármü-navigációt segítő eszközök mellett jelentősek az önjáró gépek fejlesztésére irányuló törekvések is.

\subsubsection{Gépüzemeltetés}

A precíziós gazdálkodásban a nagy értékü erő- és munkagépek megfelelő üzemeltetése is fontos feladat. A GPS-alapú flottakövetés segítségével ellenőrizhető a gépek útvonala, ami egyfajta vagyonvédelmet is jelent.

Az erőgépek CAN-bus (Controller Area Network) rendszeréről számos gépüzemeltetési adat gyűjthető, például gépterheltség, munkasebesség, motorterhelés és fordulatszám, kerékcsúszás, üzemanyag-fogyasztás. Betakarítógépek esetén ezek kiegészülhetnek a cséplési hézag és a cséplési fordulatszám, permetezőknél a permetezési idő és nyomás adataival. Az adatokból napi, havi, szezonális vagy éves jelentések készíthetők, melyek hasznos információt szolgáltatnak a szervizeléshez, a gépüzemeltetés optimalizálásához és a hatékony munkaszervezéshez. Az adatok felhasználhatók a karbantartási ütemterv összeállításához, a gépek összehasonlításához, a gépek kihasználtsága és az állásidők vizsgálatához, valamint a munkafegyelem ellenőrzésére.

A telemetriás gépfelügyeleti rendszerek lehetővé teszik, hogy a gazdálkodó vagy a szaktanácsadó bármikor távolról is ellenőrizhesse a gépek üzemelési adatait telefonon, táblagépen vagy irodai számítógépen keresztül. A közel valós időben észlelt problémákról és a javasolt beállításokról a vezető a monitoron keresztül azonnal értesíthető. A távdiagnosztika segítségével már az irodából felmérhető, hogy mi okozza az esetleges meghibásodást, így a szervizes célirányosan, az adott problémára felkészülten érkezhet a helyszínre, ezáltal csökkenthető a munkából kieső idő.

Ilyen funkciókat lát el a John Deere JDLink rendszere (KITE, 2015), az AGCO AgCommand ${ }^{\mathrm{TM}}$ rendszere (Massey Ferguson, 2014), valamint a CLAAS Telematics rendszere (Steinhauser, 2014).

\subsubsection{Szenzorok, távérzékelés}

A precíziós technológia fontos eleme a különböző szenzorokkal (érzékelőkkel) történő helyspecifikus adatgyüjtés. A szenzorok terén nagyon dinamikus a fejlődés, ezért az alábbiakban a teljesség igénye nélkül ismertetjük a gyakran alkalmazott technológiákat.

Az adatgyüjtési módszerek közt nagy szerepe van az elektromágneses sugárzás (EM) különböző tartományaiban végzett távérzékelésnek. Passzív távérzékelés esetén a szenzorok a Napból érkező, majd a felszínről visszaverődő energiát vagy a felszínek által kisugárzott energiát érzékelik. Aktív távérzékelés esetén az érzékelők a maguk által kibocsátott és a vizsgált felszínről visszaverődő energiát fogják fel.

A szenzor elhelyezkedése szerint beszélhetünk földi (pl. munkagépre helyezett szenzor), valamint légi és müholdas távérzékelésről. A repülőről készített légi felvételek és a műholdfelvételek térbeli felbontása sokat javult az utóbbi években, de nem minden esetben megfelelő a precíziós gazdálko- 
dás céljára, és nem biztos, hogy a szükséges időben rendelkezésre állnak. Az utóbbi években ezért elötérbe kerültek a pilóta nélküli légi jármủvek, hétköznapi nevükön drónok, vagy az angol név (Unmanned Aerial Vehicle) alapján UAV-ok (Zhang és Kovacs, 2012).

Minden felszínnek/tárgynak sajátos elnyelési és visszaverési spektruma van, amely az adott objektum fizikai és kémiai tulajdonságaitól, valamint geometriai viszonyaitól függ. A zöld növények klorofilltartalmuk miatt gyengén verik vissza a látható vörös sugarakat, ugyanakkor erősen visszaverik a közeli infravörös sugarakat. Ezt a tulajdonságot használják fel a különböző vegetációs indexek számításához, amelyek közül a legismertebb a normalizált differenciál vegetációs index $(N D V I=(N I R-R) /(N I R+R)$, ahol NIR a közeli infravörös és $R$ a látható vörös tartományban mért visszaverődés). Az NDRE (normalizált differenciál vörös él index) az előbbihez hasonló vegetációs index, de a látható vörös tartomány helyett egy kicsit hosszabb hullámhosszat (vörös él tartomány) használ. A vegetációs indexek alapján vizsgálható a vegetáció típusa, a növényállomány állapota, fejlődése, esetleges károsodása, és hatékony eszköz a térbeli eltérések kimutatásában (Tamás, 2013; Nagy et al., 2014). Felhasználható a nitrogén-, valamint a vízigény számítása során (Mogyorósi et al., 2011; Montgomery et al., 2015), a termésbecslésben (Ambrus et al., 2015) és a gyomnövények detektálásában is (Reisinger, 2012).

A növények szöveti felépítése meghatározó a közeli infravörös tartományban megfigyelhetö viszszaverődésnél, így ez a tartomány alkalmas a növényfajok elkülönítésére. A középső infratartományban mért visszaverődés elsősorban a növények víztartalmával van összefüggésben, de befolyásolja a levelek lignin- és cellulóztartalma is.

A betegségek vagy kártevők által okozott sérülések hatására pár fokkal megemelkedik a növények hőmérséklete, ami infravörös kamerával vizsgálható (Milics et al., 2006; Mesterházi, 2013; Tamás, 2013).

A növények/gyomok felismerése történhet a mesterséges látásra alapozva is (Milics és Neményi, 2007), amikor egy nagy felbontású kamera által készített képet dolgoz fel a fedélzeti számítógép. A drónokra szerelt nagy felbontású kamerák képeit a gyümölcsösök termésbecslésében lehet használni (Wulfsohn és Zamora Lagos, 2014).

Az aktív távérzékelési technikák gyorsan fejlődő ága a lézerszkennelés (Light Detection and Ranging, LIDAR), aminek adataiból háromdimenziós modell készíthető a vizsgált objektumról. A technológia a precíziós mezőgazdaságban a mikrodomborzat vizsgálatára (Riczu és Tamás, 2013), valamint a növényállomány felmérésére (pl. lombsürüség) és termésbecslésre használható.

Ultrahangos szenzorokkal vizsgálható a talajok rögfrakciója (Tamás, 2002), ültetvények esetén pedig a növényállomány sürüsége, valamint a fák távolsága (Balsari et al., 2009).

Az elektromos vezetőképesség (EC) alapján - nem szikes talajok esetén - következtetni lehet a talajok összetételére, tömörödöttségére és a szervesanyag-tartalomra (Tamás, 2002; Jóri et al., 2007). A talajok összetételének vizsgálatára a látható, valamint az infravörös tartományokban végzett távérzékelés is alkalmazható (Jung et al., 2015b).

A vezeték nélküli szenzorhálózatok alkalmazása leginkább a mikroklimatikus adatokat gyüjtő terepi meteorológiai állomások összekapcsolásánál jelenik meg, de felhasználható többek között a növények növekedésének monitorozásánál és az öntözés vezérlésében is (Anisi et al., 2015).

\subsubsection{Térinformatika}

A térinformatika magában foglalja a térbeli adatok gyüjtését, kezelését, elemzését és megjelenítését. A helyspecifikus adatok kezelése, a különböző adatrétegek (pl. tápanyag-ellátottság és hozam) közötti összefüggések vizsgálata, a hozam- és profittérképek, valamint kijuttatási tervek készítése 
térinformatikai módszerekkel történő adatkezelést és feldolgozást kíván (Szabó et al., 2007). Tamás (2002) szerint információtechnológiai értelemben a precíziós mezőgazdaság alkalmazott térinformatikaként fogható fel. Ezzel összhangban Stombaugh et al. (2001) egy térinformatikai program beszerzését a precíziós növénytermesztés bevezetésének első és legfontosabb lépéseként említi.

Folyamatos adatrögzítés során (pl.: koordináták, hozammérés) néhány másodpercenként történik adatgyüjtés. A pontok összekötésével követhető a munkagép útvonala, de a terület jellemzésére vonatkozó adatokat általában egy szabályos rács alapján összegzik (Berry, 1999).

A pontszerüen felvételezett adatok (pl. talajmintavétel) esetén a jelenség térbeli folyamatosságának leírásához szükség van a mért adatok közti interpolációra is. Ezt leggyakrabban a távolságokkal fordított súlyozással (Inverz Distance Weighting, IDW) vagy a krigelés (Kriging) eljárással végzik, a módszer választása függ a vizsgált adatok változékonyságától (Szabó et al., 2007). A mai térinformatikai programok általában mindkét módszert beépített modulként tartalmazzák, de az eredmények értékeléséhez szaktudás kell.

Az adatrétegek közti elemzés és ezek alapján a beavatkozási tervek elkészítése térbeli statisztikai és modellezési feladatokat igényel. Egyre több olyan program jelenik meg a piacon, amellyel a gazdálkodó maga is megtervezheti a talajvizsgálati útvonalat, elkészítheti az elemzést és a kijuttatási térképet, kiértékelheti a hozamtérképet, azonban a gazdálkodók - szaktudás hiányában - sokszor inkább szolgáltatásként veszik igénybe a térinformatikai elemzéseket.

\subsubsection{A változékonyság kezelése}

A hagyományos gazdálkodás a mezőgazdasági táblát egy egységként veszi figyelembe és azon homogén kezeléseket valósít meg, így nem minden terület kap optimális kezelést, például tápanyagutánpótlás esetén lesznek túl-, illetve alultrágyázott területek. A precíziós gazdálkodás célja a táblán belüli heterogenitások feltérképezése és az ennek megfelelő agrotechnikai beavatkozások elvégzése. A módszer azokon a területeken hatékony, ahol a táblán belüli eltérések jelentősek.

A tervezett kezelés(ek) szempontjából homogén területet menedzsment- (müvelési) zónának nevezik. A menedzsmentzónák száma és elhelyezkedése a különböző agrotechnikai folyamatok, valamint az évek során jellemzően eltér, lehatárolásukra pedig többféle módszer alkalmazható. A hozamtérkép általában jó indikátor a talajtulajdonságokkal és tápanyag-ellátottsággal kapcsolatban, használhatók hagyományos légi felvételek, multispektrális felvételek, a tervezett kezelésnek megfelelő terepi (pl. gyom-) felvételezések, valamint a gazdálkodók tapasztalatai (Zhang et al., 2010). Sok esetben - például belvizesedésre hajlamos vagy eróziónak kitett tábláknál - fontos a domborzat figyelembevétele is.

A változékonyság másik megközelítése a terület kicsi rácscellákra való felosztása, ami a vizsgált tulajdonság folyamatos változását tükrözi, és a kezelés is cellánként eltérő lehet (Berry, 1999).

Akezelési egységek mérete (a,„precizitás”) a vizsgált adatok változékonyságától, az adatfelvételezés pontosságától és a munkagép jellemzőitől (müvelési szélesség, szabályozható egységek) függ.

A differenciált kijuttatási technológia (Variable Rate Technology, VRT) során menet közben lehet módosítani a kijuttatott anyagok mennyiségét (dózisát) és/vagy összetételét. Egyaránt használható mütrágya, növényvédő szer, öntözővíz, illetve vetőmag kijuttatása esetén. Egyszerübb esetben a traktoros a sorvezető monitorán látja, hogy mikor kell nyitni vagy zárni az adott szakaszt, de általánosabb, hogy a fedélzeti számítógép automatikusan végzi a kijuttatás vezérlését. Ilyenkor a GPSegység segítségével a számítógép folyamatosan elemzi és meghatározza a munkagép helyzetét a táblán belül, és a kijuttatási terv alapján módosítja az adott táblarészre megadott dózist. 
Az utóbbi évek új kihívása a több applikációs térkép egyidejű kezelése, például változó tőszámú vetés mellett a starter mütrágya kijuttatása egy menetben.

\subsubsection{Vezérlési technikák}

Minden precíziós agrotechnika magában foglalja az adatgyüjtés, a feldolgozás és a helyspecifikus terepi beavatkozás folyamatát. Aszerint, hogy ezek a folyamatok időben és eszközrendszerükben együtt vagy elkülönülten valósulnak meg, két típus különböztethető meg (Zhang et al., 2002; Kuroli et al., 2007; Reisinger, 2012):

- Offline (adatbázison alapuló, térképalapú) precíziós gazdálkodás esetén az adatgyüjtés, az adatok feldolgozása és a beavatkozás elvégzése elkülönülten történik. Ilyen például a talajmintavételezés alapján kidolgozott tápanyag-utánpótlási terv készítése, a kijuttatási terv betáplálása a fedélzeti számítógépbe, majd az alapján a helyspecifikus trágyázás megvalósítása. Ez esetben az adatok feldolgozására, esetleges korrekciók elvégzésére több idő áll rendelkezésre.

- Online (valós idejü, szenzoralapú, menet közbeni) módszer alkalmazása esetén az adatgyüjtés, a feldolgozás és a beavatkozás szinte egyszerre történik. Ilyenkor a munkagépre szerelt szenzor adata alapján a fedélzeti (vagy a szenzorba épített) számítógép azonnal kiértékeli az adatokat és megtörténik a beavatkozás. Példaként említhető a növényszenzorok alkalmazásával végzett N-trágyázás vagy gyomirtás. A valós idejü megoldás miatt az adatfeldolgozás technikailag nehezebb és a beavatkozás több időt igényel, mint az offline tervek végrehajtása, így a gépek területteljesítménye kisebb.

Minden müvelet során a rendszer rögzíti a kijuttatott anyagok mennyiségét is, így a tervezett és a kijuttatott mennyiség a későbbiekben összehasonlítható, ellenőrizhető.

Az ISOBUS-protokoll elterjedése jelentősen segítette a precíziós gazdálkodást, mert lehetővé teszi a különböző szenzorok, az adatfeldolgozó és vezérlőegységek közötti szabványos adatcserét. Lehetővé teszi, hogy egyetlen univerzális terminállal megoldható legyen bármelyik gyártó ISOBUS-t támogató eszközének ellenőrzése és vezérlése. A felhasználó egy gombnyomással kiválaszthatja, hogy a terminálon a munkagép vagy valamelyik eszköz (vetőgép, permetező, mütrágyaszóró) kezelőfelületét szeretné látni.

Az ISOBUS-hálózat alkalmazásával nemcsak adatok, hanem vezérlőjelek is érkezhetnek a munkagépről a traktor számára.

\subsection{Szántóföldi növénytermesztésben alkalmazott technológiák}

\subsubsection{Talajtérképezés}

Talajmintavétel esetén az előző évi hozamtérkép, az elektromos vezetőképesség (EC) és a közeli infravörös tartomány (vegetációs indexek) alapján végzett felvételezést tartják a leghatékonyabbnak a mintavételi zónák kijelöléséhez (Mesterházi, 2013). Szabó és Milics (2016) kiemeli, hogy a zónák lehatárolása ne egy év felvétele alapján történjen, mert az félrevezető lehet. Számba kell venni a különböző évjáratokat és a domborzatot is. Ezeken belül 1-5 ha nagyságú mintavételi egységeket jelölnek ki. A mintavételi terv alapján elkészíthető a munkagép útvonalterve is, majd a mintavétel során az adott helyek koordinátáit is rögzítik, így a laboratóriumi vizsgálatok után elkészíthetők a területre jellemző talajtérképek.

A pH, az EC és a szervesanyag-tartalom online módszerrel, mintavétel nélkül is vizsgálható például a Veris szenzorokkal (Veris, 2012).

Pecze (2015) szerint a talajmintavétel és talajvizsgálat költsége egy évre, egy hektárra vetítve körülbelül 10 kg kukorica árának felel meg, ami elhanyagolható a benne rejlö előnyökhöz képest. 


\subsubsection{Erózió és belvíz elleni védelem}

Betakarításkor vagy más szántóföldi munkamüvelet során a GPS segítségével lehetőség van a terület magassági adatainak rögzítésére is, és ezáltal a domborzatmodell létrehozására.

Dombos területeken az egyik legnagyobb probléma a talajerózió. Ez sok esetben talajkímélő müvelési módszerekkel (mulcshagyó művelés, sávművelés) és talajtakaró növények alkalmazásával elkerülhető, más esetekben szükség van a rétegvonalas müvelésre. Ilyenkor a müveletek iránya mindig merőleges a lejtés irányára - csökkentve ezzel a lefolyó víz sebességét -, ezáltal mérsékelve az eróziót. Önmagában a rétegvonalas művelés 2-10 százalékos lejtésű területeken hatékony. Ennél meredekebb domborzati viszonyoknál, illetve barázdás és árkos erózió megjelenésekor célszerübb az átjárható füvesített rétegvonalsávok vagy vízelvezetők kialakítása. A rétegvonalas müvelés megvalósításához szükséges kontúrvonalak a terület domborzatmodellje alapján jelölhetők ki, a későbbi müveletek során pedig a műholdas navigációval egyszerủen követhetők (KITE, 2016a).

Az ország jelentős részén probléma a belvizes foltok kialakulása is. A terület domborzatmodellje alapján meghatározható az ideális lefolyást biztosító árok nyomvonala vagy nagyobb belvizes területeken az árokhálózat, annak mélysége és lejtése. A GPS-antennával felszerelt erőgép és ároknyitó egy szintezésvezérlő program alapján ezt pontosan el tudja készíteni. A technológiát elsőként a KITE és a John Deere mutatta be Magyarországon (Demes, 2015).

\subsubsection{Tápanyag-visszapótlás}

Foszfor és kálium esetén a talajvizsgálati adatok alapján történhet a szükséges mennyiség meghatározása. Zhang et al. (2002) szerint a differenciált kijuttatási technika kapcsán a legtöbb fejlesztés a nitrogén kijuttatásával kapcsolatos, ezen a területen az utóbbi években elterjedtek az online rendszerek is (OptRx, Crop Sensor, Yara N-sensor, Trimble Green sensor). Ezek a korábban ismertetett vegetációs indexeket kapcsolják össze a növény nitrogénigényével (búza, árpa, burgonya, repce esetén létezik modell), de a használat elött egy rövid kalibrációt kell elvégezni. A saját fényforrással is rendelkező rendszerek (pl. Yara ASL) lehetővé teszik, hogy akár sötétedés után is lehessen dolgozni.

Szilárd mütrágya esetén a repítőtárcsás mütrágyaszórók alkalmazhatók, folyékony mütrágyák esetén önjáró vagy vontatott permetezőgépek.

Környezetvédelmi szempontból a mezőgazdasági tevékenység egyik legvitatottabb pontja a mütrágya-felhasználás, ezen belül is az N-mütrágyák alkalmazása. A precíziós mütrágyázásról is megoszlanak a vélemények, vannak, akik a csökkenő mennyiségü felhasználást (Csathó et al., 2007), mások inkább a termésmennyiség 15-20 százalékos növekedését szokták kiemelni (Benedek, 2011). Csathó et al. (2007) többéves kísérlet alapján azt is megállapította, hogy a helyspecifikus műtrágyázással a növényzet képes a szélsőséges időjárási viszonyokat kompenzálni, így az eltérő klímaviszonyok miatti hozamkülönbségek csökkennek.

\subsubsection{Vetés}

A talaj tömörödöttségét érzékelő szenzorok alapján folyamatosan változtatható a vetési mélység, elsősorban függesztett munkagépek esetén (Tamás, 2002).

A precíziós vetés lehetőséget ad a felülvetés megakadályozására is. A fedélzeti számítógép tárolja a már bevetett sorokat, így a későbbiekben, ha egy szabálytalan alakú tábla esetén a vetőgép már bevetett területre ér, akkor a sorelzáró kuplung segítségével letiltja a vetőelemeket.

Másik cél lehet a változó tőszámú vetés. Ilyenkor a gyengébb területeken kisebb, míg a jobb termőképességü területeken nagyobb tőszámmal lehet vetni. A szakaszvezérlés segítségével az is megoldható, hogy a nagyon rossz adottságú területekre (belvizes, szikes foltok) feleslegesen ne szórjanak ki magot. 
A precíziós vetési módszerek csökkentik a feleslegesen kivetett vetőmag mennyiségét, de a megtakarítás mértékéről eltérőek a vélemények. Sulyok (2016, szóbeli közlés) szerint 2-5 százalékos, Karpjuk (2016) szerint 3-7 százalékos, míg Tamás (2002) alapján akár 5-15 százalékos vetőmagmegtakarítás is elérhetö.

\subsubsection{Növényvédelem}

A kártevők, betegségek és gyomok ritkán fordulnak elő egyenletesen egy táblán belül. Ahol a kártevők nem vagy csak a kártételi küszöb alatti mennyiségben fordulnak elő, ott elmaradhat a védekezés, ami jelentős költségmegtakarítást jelenthet és csökkenti a környezet peszticidterhelését (Kuroli et al., 2007; Takács-György és Takács, 2011). Egy felső korlát is meghatározható, ami felett a teljes felszín kezelése célravezető, a két kártételi határ közt indokolt a precíziós növényvédelem (TakácsGyörgy és Takács, 2011).

Az adatfelvételezés készülhet terepi felméréssel (pl. évelő gyomfoltok lehatárolása) vagy távérzékeléssel.

A talajherbicidek hatóanyagai az eltérő szervesanyag-tartalmú talajokon eltérő módon kötődnek meg, ezért a gyomirtó szer mennyiségének meghatározásához a precíziós talajmintavétel adatainak felhasználása is fontos (Pecze, 2009).

A modern permetezőgépek szórókeretei akár szórófejenként is szakaszolhatók. Offline módszer esetén két törzsoldat alkalmazásával beprogramozható, hogy hol kell csak egyszikü, csak kétszikü, illetve mindkét típusú gyom ellen védekezni, és hol maradhat el a permetezés.

A szórófejekhez szerelt online szenzorok (Weed seeker) jól alkalmazhatók a preemergens gyomirtásban, amikor a terepen érzékelt minden növény gyomnak tekinthető, de a szórófejet egy elsodródást gátló burkolattal körbevéve eredményesen alkalmazták a módszert a kukorica sorközi gyomirtásában is (Reisinger, 2012). Az online módszer esetén nem ismert előre a permetlé szükséges mennyisége, ezért olyan injektoros rendszert célszerü alkalmazni, ami a vegyszerből és a szállított tiszta vízből a helyszínen állítja elő a megfelelő koncentrációjú oldatot.

Precíziós gyomszabályozással a szakirodalmi adatok többsége szerint 30-50 százalékos herbicidmegtakarítás érhető el, Reisinger et al. (2012) azonban búza gyomirtásában 60-70 százalék megtakarítást is elértek.

A nagy pontosságú RTK-korrekció alkalmazásával, nagyobb térállású kultúrákban (kukorica, napraforgó) lehetőség van a sorközökben mechanikai gyomirtásra kultivátorral vagy speciális kapálógéppel. A sorvezérelt (szenzorvezérelt) kultivátorozásnál a kultivátorra szerelt optikai szenzor végzi a növénysorok azonosítását és követését (pl. Garford sorközmüvelö kultivátor). A rendszer robotpilóta nélkül is használható, de azzal együtt különösen hatékony, használatával $5-10 \mathrm{~cm}$ sormegközelítés érhető el, és növelhető a traktor sebessége. A mechanikai és a vegyszeres gyomirtás kombinálható a kultivátorra szerelt permetezőfejekkel.

A mechanikus gyomirtás ma már bakhátas kultúrák esetében is alkalmazható. Ilyenkor a sorközök gyomtalanításán túl megtörténik a barázdaoldalak gyommentesítése és helyreállítása is (Borsiczky és Reisinger, 2013).

\subsection{6. Öntözés}

A vízigény meghatározása történhet a talaj vízkapacitásának vizsgálata alapján (Hedley, 2010) vagy a növények állapotának távérzékeléses vizsgálatával, valamint több tényező - domborzat, növényi borítottság, növényi vitalitás, talaj-vízpotenciál, napsugárzás - együttes figyelembevételével (Hajdú, 2015). 
A változtatható intenzitású öntözés egyik lehetősége a szórófejek vezérlése, másik lehetőség az öntözőgép sebességének változtatása. Mindkettő megvalósítható a körforgó vagy lineár rendszer esetén is. Az önjáró berendezések nyomvonala DGPS vagy RTK navigációs rendszerekkel, vízadagja számítógépes programmal módosítható. Körforgó öntözőberendezéseknél akár 0,1 fokonként is képezhetök szektorok, a legkisebb lehatárolható öntözési zóna pedig pár négyzetméter is lehet (KITE, 2016b). A technológia alkalmazásával megvalósítható az öntözőberendezés által bejárt területen lévő különféle, illetve eltérő állapotú növények differenciált vízmennyiséggel történő öntözése vagy a változó domborzati és talajadottságokhoz igazodó vízmennyiség kijuttatása. Hedley (2010) alapján a precíziós öntözéssel 9-26 százalékkal csökkenthető a felhasznált víz mennyisége.

Több cég kínál egy vagy több öntözőberendezés távfelügyeletét és távmüködtetését ellátó rendszereket is (Hajdú, 2015).

Magas beruházási költsége miatt szántóföldön kevésbé elterjedt megoldás a mikroöntözés, ami pontosan szabályozható víz- és tápoldat-kijuttatást tesz lehetővé.

\subsubsection{Hozamtérképezés}

A vegetációs indexek szoros pozitív összefüggést mutatnak a biomassza és a termés mennyiségével, ezért jól alkalmazhatók a termés becslésére, a táblán belüli heterogenitások vizsgálatára. A betakarítás során végzett mérés azonban pontosabb adatokat szolgáltat.

A mai korszerü betakarítógépeken általában alapfelszerelésként megtalálhatók a hozam- és szemnedvességmérő szenzorok. Szériafelszereltségként vagy opcióként - akár utólag is - egy GPSvevő hozzáadásával ezek a betakarítógépek alkalmassá tehetők a hozam térképezésére. Az adatok gyüjtését kalibrációnak kell megelöznie, mert a szenzorokat össze kell hangolni az adott betakarítógéppel (Milics et al., 2014).

A hozamtérképező rendszerek néhány másodpercenként rögzítik és földrajzi koordinátákhoz rendelik a learatott termés mennyiségét és nedvességtartalmát. Hektáronként kb. 500-600 pont kerül rögzítésre (Mesterházi, 2013). Az eredmények értékelésekor problémát jelenthet, ha a vágószélesség nincs jól beállítva, ha nem a teljes vágószélesség van beállítva vagy nem megfelelő a kapcsolási magasság beállítása (fordulóknál hibás értékek lesznek), ezért ezen adatok további felhasználása előtt adatszürésekre lehet szükség. A hozamadatok térképezésével feltárható a táblán belüli változékonyság, ez alapján pontosabbá tehető a következő évi tápanyag-utánpótlás tervezése is. Ha a hozamtérkép nem mutat nagy eltéréseket, akkor elképzelhető, hogy a gazdálkodónak nem érdemes befektetnie a differenciált tápanyag-kijuttatásba, csak a precíziós technológia egyéb elemeinek használatába.

A hozamtérképekből - megfelelő szoftverek segítségével - jövedelmezőségi térképek is elöállíthatók, melyekkel a terület jövedelemtermelő képessége a tábla részleteire vonatkozóan vizsgálható. Hosszabb idősor vizsgálata esetén megerősíthetik a döntéshozókat a munkájukban (Smuk et al., 2010).

\subsection{Precíziós kertészet és szőlészet}

\subsubsection{Szántóföldi zöldségtermesztés}

Szántóföldi zöldségtermesztés során többnyire a korábban ismertetett precíziós technológiák használhatók, eltérés elsősorban az öntözés és a hozamtérképezés módszereiben van.

A változtatható intenzitású öntözést lehetővé tevő lineár rendszerek mellett a zöldségtermesztésben nagyobb jelentősége van a csepegtető és mikroszórófejes öntözésnek, elsősorban a lösz- és homokhátságokon. Paprika, paradicsom, uborka esetén inkább a csepegtető, káposztafélék és gyökérzöldségek esetén a szórófejes öntözés az elterjedtebb (Noel, 2003; Haszon Agrár Magazin, 2013). 
Gépesített betakarításnál a betakarítógép kiegészíthető GPS-szel és a termés mennyiségét mérő szenzorral, kézi betakarításnál a terület cellákra osztása és az erre jutó termésmennyiség rögzítése lehet a hozamtérképezés alapja (Zude-Sasse et al., 2016). Az automatizált betakarításra paradicsom, uborka, sárgadinnye esetén már vannak robotok, és ezek további terjedése várható (Zhang et al., 2002). Blackmore (2016b) szerint jelenleg a kézzel betakarított zöldségek 20-60 százaléka minőségi problémák miatt nem adható el a szupermarketeknek, a jövőben ez akár 100 százalékban megfelelő minőséggé változtatható a szelektív betakarításra képes robotokkal. A növények pontos helye, mérete, várható növekedése alapján sokkal pontosabban tervezhető a többmenetes betakarítás.

\subsubsection{Szőlő- és gyümölcsültetvények}

Ültetvények esetén a precíziós technológia egy-egy fára vagy fák kisebb csoportjára vonatkozik. A térbeli eltérések kezelése mellett nagy jelentősége van az időbeli változásoknak megfelelő kezelések alkalmazásának is.

A GPS-es helymeghatározás segíti a fák helyének kijelölését a telepítéskor. Később, fejlett lombozatú ültetvényekben a GPS használata korlátozott. Az antennát nem lehet közvetlenül a munkagépre helyezni, hanem egy rúd segítségével olyan magasra kell emelni, hogy a fák ne akadályozzák a jelek vételét, ez azonban jégvédő háló használata esetén nem mindig megoldható. A szántóföldi növénytermesztésnél sokkal ritkább sor- és tőtávolság miatt nincs szükség az RTK-pontosság használatára, a deciméter vagy sok esetben az egy méter alatti pontosság is megfelelö.

A fák egyedi azonosítására vonalkód, QR-kód (kétdimenziós vonalkód) vagy RFID (rádiófrekvenciás azonosítás) is használható (Qian et al., 2015; Zude-Sasse et al., 2016). A QR-kód alkalmazása előnyösebb, mert okostelefonnal is leolvasható, míg az RFID használatához költségesebb leolvasó szükséges.

A talajadottságok feltérképezése a szántóföldekhez hasonlóan az elektromos vezetőképesség (EC) vagy mintavétel alapján történhet.

A növények állapota a vegetációs indexekkel (leggyakrabban NDVI), a lomb sürüsége és mérete ultrahangos vagy Lidar-felméréssel jellemezhető. Ezek alapján tervezhető a tápanyag-utánpótlás vagy a növekedés- és termésszabályozás (Riczu et al., 2013). Szántóföldi növénytermesztéshez hasonlóan nitrogéntrágyázás esetén online módszer is használható. Ilyenkor a különböző magasságokban elhelyezett szenzorok segítségével biztosítható a fák méretének megfelelően differenciált hatóanyag kijuttatása (Schumann, 2010).

A precíziós növényvédelem terén több jelentős fejlesztés történt, amelyeknél különböző szenzorok kombinálásával érhető el a specifikus beavatkozás. Távérzékelés segítségével vizsgálható a levelek károsodása, kimutathatók a megbetegedések, például az almafa varasodás és a lisztharmat (Nagy et al., 2014) vagy a szőlő levélsodródása (Lee et al., 2010). Ultrahangos szenzorral megállapítható a lombozat volumene, így a különböző magasságban elhelyezkedő szórófejek ennek megfelelöen vezérelhetők, illetve a fahiányok felismerésével elkerülhető a felesleges permetezés (Balsari et al., 2009). A szél irányának és erősségének figyelembevételével a cseppméret és a légáram is szabályozható, hogy minél kisebb legyen az elsodródás (Doruchowski et al., 2011).

Ültetvényekben nagy jelentősége van a vezeték nélküli szenzorhálózatoknak (WSN), amelyekkel a környezeti adatok monitorozhatók. A mikroklimatikus viszonyokat jellemző meteorológiai állomások előrejelző programokkal együtt elsősorban a gombás megbetegedések, míg a kamerával felszerelt „távcsapdák” a kártevők elleni védekezésben hatékony eszközök.

A nagy értékü kertészeti termékek esetén az öntözés kritikus jelentőségü, de a jó minőségű termés elérése mellett a víztakarékos megoldások használata a cél. Az ültetvények mikroöntözése megvalósítható mini esőztető vagy csepegtető fejekkel, amelyeket a növények vízigénye alapján lehet 
vezérelni. A vízigény meghatározása történhet terepi szenzorhálózat vagy távérzékelés - termál infra vagy multispektrális felvétel - alapján számított vízhiányindexekkel.

Ültetvényekben nehezebb a hozamtérképezés, mint a szántóföldön, gyakran nem is egy menetben történik a betakarítás. Gépi szőlöbetakarításhoz többféle szenzor is kapható, amelyek lehetővé teszik az automatikus hozamtérképezést (Matese és Di Gennaro, 2015). Kézi betakarítás esetén lehetséges megoldás a megtelt szedőládák tömegének és helyének rögzítése, majd adott területre (fákra) való vonatkoztatása vagy a fánként leszedett termés mérése.

Másik lehetőség a távérzékeléses termésbecslés még a betakarítás elött. A felmérés történhet a sorközben haladó jármüre vagy drónra szerelt kamerával vagy Lidar-érzékelővel (Riczu et al., 2016), esetleg müholdas felvétel alapján. Sokáig a multi- vagy hiperspektrális felvételekből számított vegetációs indexeket használták a termésbecslésre, jelenleg terjednek a mesterséges látáson alapuló módszerek (Lee et al., 2010). Ilyenkor a felvételeken el kell különíteni a termést és a lombozatot, majd statisztikai alapon becsülhető a termés mennyisége. Automatikus képfeldolgozáson alapuló módszerrel 10 százaléknál kisebb eltéréssel tudták meghatározni a Tramini és Rajnai rizling termésmenynyiségét (Nuske et al., 2011), míg Red Delicious és Granny Smith almafajtáknál sztereofelvételek alapján mindössze néhány százalékos volt az eltérés (Wang et al., 2012).

A multi- és hiperspektrális felvételek, a spektroszkópia, valamint fluoreszcenciamérés segítségével számos minőségi jellemző (pl.: szárazanyag-, karotinoid-, antocianid-, polifenol-, cukor- és savtartalom) laboratóriumi vizsgálat nélkül is meghatározható (Matese és Di Gennaro, 2015; Szuvandzsiev et al., 2014; Jung et al., 2015a; Zude-Sasse et al., 2016). A módszer alapul szolgálhat a válogató eljárásokhoz, illetve az ültetvényben helyspecifikusan felmért adatokból termésminőségi térképek készíthetők. Ennek kiemelt jelentősége van a szőlőtermesztésben.

\subsection{3. Üvegházak}

Üvegházak esetében nem a klasszikus értelemben vett helyspecifikus, termőhelyhez igazodó termesztésről van szó, inkább az adott növény számára ideális feltételek biztosításáról. A hőmérséklet, páratartalom, fény, tápoldat és öntözővíz szabályozásában régóta fontos szerepe van az üvegházak automatizálásának, ezt támogatják az egyre szélesebb körben elérhető és használt szenzorok, illetve szenzorhálózatok.

A műholdas helymeghatározás helyett egyéb azonosítási módszereket (pl. RFID) kell alkalmazni, ahogy a növények állapotát vizsgáló távérzékelés is csak földi szenzorokkal valósítható meg. Ezek használatával végezhető el a differenciált kijuttatás akár az öntözés, a tápoldatozás vagy a növényvédelem terén.

\subsection{Precíziós állattenyésztés}

A precíziós technológiák az állattartásban kevésbé ismertek hazánkban. Ugyanakkor folynak vizsgálatok a különböző precíziós állattartási technológiák gyakorlati alkalmazhatóságával kapcsolatban, és vannak szolgáltató cégek, amelyek kínálatában már szerepelnek professzionális telepirányító rendszerek. A teljesség igénye nélkül ismertetjük a fontosabb alkalmazási területeket.

\subsubsection{Technikai háttér}

Az 1980-as évek közepétől az elektronizálás és a mikroelektronika alkalmazása révén felgyorsult az állattartás technikai fejlödése. Az állattartó telepeken megkezdödött a számítástechnikai eszközök felhasználása, majd a 90-es évektől a robotok felhasználása (Tóth, 1998), melyek a precíziós állattenyésztés első lépéseinek tekinthetők. 
A precíziós technológia alapvető feltétele az állatok megfelelő azonosítási rendszere. Erre a célra jól alkalmazhatók a rádiófrekvenciás azonosítók (RFID-egységek), más néven transzponderek, melyek aktív és passzív kivitelben készülnek. A gyakorlatban a passzív válaszadók az elterjedtebbek (Béri, 2011; Tóth, 2013). A szarvasmarháknál föként a nyakszíjukra erősített nagyméretü transzponderek a használatosak, de borjaknál, sertéseknél, juhoknál elönyösebben alkalmazhatók a chipméretü kivitelek, melyek között létezik fülkrotáliába szerelt, testbe, illetve bőr alá injektálható (inplantálható), valamint lenyelethető változat (bolus tag szarvasmarhák és juhok azonosítására) is. Baromfifajoknál Tóth (2011) vizsgálta az RFID-rendszer szárnyjelzőként való alkalmazhatóságát. Ezek a berendezések lehetővé teszik a viszonylag nagy olvasási távolságot és a gyorsabb adatátvitelt. Segítségükkel több technológiai folyamat automatizálható és számos információ gyüjthető. Az adatgyüjtővel ellátott állatazonosító rendszerek a hatékonyság növelésén túl az állatok környezetének javítását, a termékek minőségének növelését is szolgálják.

A rádiófrekvenciás azonosítók mellett léteznek olyan azonosítók is, amelyek leolvasása infravörös sugárzással, optikai úton történik (Tóth et al., 2009).

A precíziós technológia szenzorokra épül, amelyek a termelést befolyásoló tényezőket mérik, adatokat gyüjtenek. E technológiai egységek és a telep vezérlő számítógépe között online kapcsolat van, a mért adatok bekerülnek a rendszer adatbázisába. A modern technológia révén a gazdák különböző paramétereket mérve megfelelően szabályozhatják például a szellőztetést, a takarmányellátást, a fütést, illetve a hütést, de a mai napig kevés olyan eszköz van használatban, amelynek középpontjában maga az állat áll. A technológiai fejlődés eredményeképpen már rendelkezésre állnak pontos, hatékony és megfizethető eszközök, mint például kamerák, mikrofonok, érzékelők, vezeték nélküli kommunikációs eszközök, internetkapcsolat, felhőalapú adattárolás. Ezek az eszközök képesek az egyes állatok egyedi ellenőrzésére, mintegy „helyettesítik a gazda szemét és fülét”, aki nem lehet folyamatosan az állatokkal. A technológia ugyanakkor ,csak” támogatást nyújt a megfelelö döntések meghozatalához és az idejében történő beavatkozáshoz, tehát a gazda szakértelme továbbra is kulcsfontosságú (Berckmans, 2014; Tullo et al., 2013).

A precíziós állattartás a telepített szenzorok által folyamatosan (különböző idöbeli felbontásban, naponként, óránként stb.) gyüjtött adatokat modellek, algoritmusok segítségével feldolgozza, elemzi és a menedzsment számára értelmezhető formába alakítja át, amit a gazdálkodó internetes felületen érhet el, számítógépen vagy okostelefonon keresztül. A technológiai szolgáltatók szolgáltatásuk részeként egyre gyakrabban biztosítanak valamilyen figyelmeztetési alkalmazást (e-mail, SMS) is, amennyiben a megfigyelt paraméterek valamelyike elér egy kritikus értéket (Könyves et al., 2015). A gazda ennek ismeretében tudja ellenőrizni a körülményeket, és szükség esetén közbelép, így a hibák még időben elháríthatók.

\subsubsection{Tejelő szarvasmarha}

A fejés több müveletének automatizálása már az 1980-as évektől megoldott, az állatok számítógépes elektronikus azonosítása azonban további lehetőségeket teremt (Tóth, 2013). Minden egyes tehén nyomon követhető, automatikusan elkülöníthető kezelésre, egyedileg vagy csoportonként etethető és kijelölhető speciális tenyésztési programokhoz. Ha a tehénazonosítással müködő telepirányító rendszerhez aktivitásmérő és egyedi tejmérő van csatlakoztatva, akkor automatikusan felismerhetők az ivarzási jelek és az egészségi problémák.

Minden fejésnél automatikusan rögzítésre kerülhetnek a termelés alapvető adatai, mint például az adott időszakban várt és ténylegesen fejt tejmennyiség, a tej hőmérséklete, vezetöképessége, összetétele, a szomatikus sejtszám (ami utalhat tőgygyulladásra), a fejés időpontja és időtartama, a fejés intenzitása stb. A rendszer automatikusan kiértékeli az adatokat, jelzi, ha valamelyik tehén termelési 
jellemzője eltér a várt értéktől, s a fejés után elkülönítő helyre irányítja. A telep vezetőjét figyelmezteti a tennivalókra, és azt is megmutatja, ha azokat nem végezték el.

A fejörobotok a fejés teljes automatizálását biztosítják, a korábban problémát jelentő kelyhek felhelyezését is. Ennél a müveletnél a bimbók érzékelésének leggyakoribb módja a robotkar végén lévő lézerdiódából kibocsátott pásztázó lézersugár. A bimbók felületéről visszaverődő lézersugarakat a jelfogók érzékelik, s a visszaverődés időtartamából pontosan meghatározható a robotkar és a bimbók távolsága, térbeli elhelyezkedésük, s ez alapján adja az utasítást a vezérlö PC (Tóth, 2013). Megválasztható az optimális fejési időpont, szabályozható a fejések száma és az egyes fejések között eltelt idő. A fejés nyugodt, stresszmentes környezetben történik. Hatékony módszer és minimális munkaerőt igényel, viszont a berendezések szervizeléséhez nagy szaktudás szükséges, és az egyállásos, úgynevezett kompakt egységek optimálisan csak kisebb állatlétszámú telepeken müködtethetők, nagyobb üzemeknél robotizálásra leginkább a karusszel fejőberendezések alkalmasak.

Automatizált mérlegeket használva folyamatosan tájékozódhatunk az állatok súlyáról. Általában a fejőberendezés felhajtóútjába építik be a mérlegeket. A kiugró érték utalhat takarmányozási problémára vagy anyagcserezavarra.

A tehenek mozgási aktivitásának mérésével az ivarzás, illetve egyéb állategészségügyi állapotok jól nyomon követhetők. A mozgási aktivitást az állat nyakába akasztott mozgásérzékelővel vagy a lábára csatolt pedométerrel mérik, amely az egyedi azonosítóval egybeépíthető. Az érzékelök leolvasása a fejőberendezésnél történik. A rendszer tájékoztat az ivarzás óta eltelt napok számáról, az egyed átlagos mozgási aktivitásáról és a mozgásban bekövetkezett lényeges változásokról is. Az ivarzó tehenek nyugtalanabbak, időegység alatt többet mozognak. Ivarzáskor a normál lépésszám akár kétháromszorosára is megnőhet. A lépésszám mérése más információkkal (tejtermelés, testhőmérséklet, tenyésztési adat) kiegészítve alkalmas az ivarzó egyedek kiválogatására, az optimális termékenyítési idő megállapítására. Az automatikus osztályozó kapu segítségével a fejés végére a termékenyítendő állatok külön részbe kerülhetnek.

A csökkenő mozgásaktivitást is jelzi a rendszer, ami betegségre (sántaság, anyagcsere-rendellenességek) utalhat.

Tóth et al. (2009) vizsgálták az állatok viselkedésének pontosabb jelzését ID Tag-hez csatlakoztatott processzor segítségével. A berendezést az állat nyakszíján helyezték el. Az ID Tag mellett az aktivitásmérő kiegészítőjeként mikroprocesszort is beépítettek, amely a programja révén a mozgás pillanatában képes megkülönböztetni a mozgást kiváltó okokat. A mért adatokat osztályozza, a memóriaegységébe elmenti és leolvasásig tárolja. A leolvasás antennák segítségével, infravörös sugárzással optikailag történik, nemcsak a fejési helyen, hanem több etetési ponton is. A gyakoribb leolvasás megbízhatóbb, az események korábban észlelhetők, ami gyorsabb beavatkozást tesz lehetővé.

Az állatok egyedi azonosítórendszere mellett minden tehén a megfelelö takarmányadagot kaphatja laktációs szakaszától, tejtermelésétől függően. Megállapítható az elfogyasztott takarmány mennyisége, amely a közvetlen etetési információkon túl egészségügyi, szaporodásbiológiai információkat is nyújthat.

A sántaság gyors felismerésére és a kellő időben történő beavatkozásra több vizsgálat is irányul. Ilyen a kamerák elhelyezése a fejőberendezéseknél, melyek képi információt rögzítenek járás közben az állatokról. Ezeket egy képelemző és számítási modell feldolgozza és felismeri a sánta járás paramétereit (Berckmans, 2014).

Tóth et al. (2009) Magyarországon végzett vizsgálatuk során igazolták, hogy precíziós technika segítségével lehetővé válik az állatok lábbetegségének korai szakaszban történő felismerése, amikor még szabad szemmel nem észlelhető mozgásbeli eltérés. Így lehetővé válik a korai beavatkozás, 
csökkentve a kezelés költségeit, megelőzve a jelentős termeléskiesést. A sántaságvizsgáló berendezést a fejőberendezések felhajtó vagy visszahajtó folyosóján helyezik el (akár az automatikus mérleghez csatlakoztatva). A vizsgáló egység három részből áll, két szélső része a talajra rögzített, középső része pedig elektrotenzometrikus nyomásmérő cellákon nyugszik. Az állatok áthaladásakor a müszer érzékeli a lépésenként rá gyakorolt nyomást (tehát a lábakra jutó terhelést), a nyomásváltozás frekvenciáját. A mért értéket a csatlakozó PC összehasonlítja az adott állat referenciaszintjével (az egészséges állat áthaladásakor mért értékkel), az attól való eltérést azonnal érzékeli és jelzi, amelyből a lábak állapotára lehet következtetni.

\subsubsection{Sertés}

A sertéstelepeken a precíziós technológiák közül leginkább az egyedi takarmányellátás ismert.

Magyarországon is elérhető már olyan telepirányítási rendszer, amely azon túlmenően, hogy biztosítja minden egyes koca számára, hogy megfelelő időben hozzájusson a pontos takarmányadagjához, felismeri, azonosítja és elkülöníti az ivarzó egyedet. Figyelemmel kíséri a takarmányfelvételt, az állatok gyarapodását, viselkedését, ezáltal korán azonosíthatók a potenciális egészségügyi problémával rendelkező állatok (Kovács, 2011).

A valós idejü köhögésszámlálással az állatok légzőszervi megbetegedése és annak súlyossága vizsgálható (Könyves et al., 2015). Ennek módja az akusztikus monitorozás mikrofonok beépítésével. Jelenleg még komoly kihívást jelent elkülöníteni a köhögést az egyéb zajoktól, illetve megkülönböztetni a kóros köhögést a nem patológiás eredetü köhögéstöl. Figyelembe kell venni az osztályozás hibáját, vagyis azt, amikor a rendszer a köhögést nem köhögésként azonosítja vagy fordítva, egyéb zajokat köhögésként azonosít, mert a hiba ismeretének hiányában szakmailag nehezen értelmezhetők az adatok, ugyanakkor a mért adatokat grafikusan megjelenítve jól megfigyelhetők a tendenciaváltozások.

Kamerák segítségével mérhető az állatok aktivitása. Folyamatosan lehet rögzíteni digitális fényképeket az állatokról, melyek egy központi számítógépbe kerülnek, ott egy szoftver elkülöníti az állatok színét a környezetétől. A nyers felvételekre egy rácshálót illeszt, amelynek lefedettségéből számít egy aktivitási indexet. Az index értéke szakmailag nehezen értelmezhető, viszont a grafikus megjelenítésből jól láthatók a tendenciák és a változások. Az állatok mozgásintenzitásából, az istállóbeli eloszlásukból következtetni lehet a viselkedésükre, a jóléti körülményeikre. Az aktivitás növekedése eredhet például csoporton belüli agresszivitásból (pl.: telepítésnél, átcsoportosításnál) vagy jelentkezhet a használható területek valamely oknál fogva történő csökkenéséböl.

Az állattartó épületek légterében előforduló szennyező anyagok (ammónia, metán, szén-monoxid, szén-dioxid, kén-hidrogén, por, mikroorganizmusok) az állatok és a dolgozók egészsége szempontjából is fontos paraméterek. Emellett a hőmérséklet, a páratartalom és a légmozgás folyamatos mérése is szükségszerü az egészség, az állatjólét biztosításához. A levegőhigiéniai mérőműszerek időszakos kalibrációra és cserére szorulnak. Fontos, hogy napi értékek ez esetben nem elegendőek, a napon belüli változásokat is nyomon kell követni.

A takarmányfogyasztás csökkenése utalhat betegségre vagy a takarmánykiosztó rendszer hibájára, ezért az állatok egészsége és a termelés szempontjából is indokolt a folyamatos megfigyelés. A precíziós technológiák egy etetőbe szerelt speciális mérleg segítségével mérik a takarmányfogyást, ami eltérhet a tényleges takarmányfogyasztástól. Nehézséget jelent, hogy a különböző formájú (pl.: granulált, dercés) takarmányok sürüsége eltérő, illetve a takarmánykiosztás technikája más és más.

A testtömegmérés tájékoztat a termelés gazdaságosságáról és az állatok egészségi állapotáról (Sa et al., 2015). A várt értékektöl való elmaradás utalhat egészségügyi, tartási vagy takarmányozási problémákra. A mérést folyamatosan és stresszmentesen kell végezni. A precíziós technológiák az 
etetőhöz szerelt kamerák segítségével az állatok körvonalát meghatározva becsülik meg a testtömeget és csoportonként adnak meg napi átlagértéket.

\subsubsection{Baromfi}

A baromfiágazatban, hasonlóan a sertéságazathoz, szintén a takarmányozásban terjedtek el leginkább a precíziós módszerek. Itt is folynak azonban különböző fejlesztések további precíziós technológiák bevezethetőségével kapcsolatban.

Kamerák elhelyezésével folyamatosan nyomon követhetö a madarak aktivitása, eloszlása (Berckmans, 2014). A rendszer a sertéseknél fentebb leírt módon müködik. Folyamatosan figyelemmel kísérhető, hogy az állatok a takarmányellátásra megfelelő súlygyarapodással reagálnak-e. Kontrollcsoport alapján elöre meghatározott növekedési görbéhez viszonyíthatók a mért értékek.

Képelemző technikák mellett hangelemző módszerek fejlesztése is folyik. Fontana et al. (2015) vizsgálták a brojlercsirkék által kibocsátott hang frekvenciája és a növekedésük közötti összefüggést, és a modell (lineáris regresszió) megerősítette, hogy az állatok súlya megbecsülhető a kibocsátott hang frekvenciaanalízisével. Létezik olyan belga kutatók által kifejlesztett technológia, mely a brojlercsirkék által kibocsátott hangokat elemezve azonosítja az állatok viselkedésében bekövetkező változásokat, mint például a fokozott stresszt vagy a csökkenő takarmányfelvételt (Davies, 2016). A hangokat számítógép értelmezi és figyelmezteti a gazdát a lehetséges egészségügyi vagy jóléti problémára. A kutatók szerint ez a módszer hatékonyabb a kameraalapú nyomon követésnél.

\subsection{Talajkímélő gazdálkodás}

A talajkímélő (vagy talajvédő) gazdálkodás nem szükségszerüen jelent precíziós gazdálkodást, és a precíziós gazdálkodás sem eredményez egyértelműen talajkímélő gyakorlatot, de sokszor együtt járnak.

A talajkímélő müvelés a talajállapot és a talajélet javítását, a talajnedvesség megőrzését, a humusztartalom növelését tüzi ki célul. Alapelvei közt szerepel a csökkentett menetszámú talajmüvelés, a talaj takarása szerves anyaggal és a vetésforgó. Az alkalmazott technikák közé sorolható a talajművelés mellőzése (no tillage), a zóna-, sáv- vagy sormüvelés, a takaró- és zöldtrágyanövények ültetése, a talaj takarása növényi maradványokkal, a direktvetés, valamint a gyomnövények elleni védekezés kontakt gyomirtókkal (Underwood et al., 2013). Ez a művelésmód azonban nem alkalmazható minden talaj esetén, speciális felszerelést és új gazdálkodási ismereteket igényel.

Csökkentett menetszámú (redukált) talajmüvelés esetén a hagyományos talajmüveléshez hasonlóan a teljes felületen történik müvelés, forgatással (szántással) vagy anélkül. A müveletek összevonása, illetve elhagyása akár 50 százalékkal is csökkenti a hektáronkénti idő- és energiafelhasználást (Birkás, 2008; Husti, 2015), ami föleg a nagy területen gazdálkodók számára fontos. A csökkentett menetszámú technológiák esetén a gépi munkák költségei jelentősen kisebbek, mint az őszi szántásos technológiánál, azonban figyelembe kell venni a gépek magasabb bekerülési értékét, amortizációs és javítási költségeit, és a gépek kihasználásához szükséges termőterülettel kell rendelkezni (Sulyok, 2005). Ez a művelésmód elsősorban kötöttebb talajon és száraz időjárási körülmények közt javasolt (Väderstad, 2016).

A szántás nélküli technológia során mélyebb művelés esetén középmély lazítót alkalmaznak, ami a növényi maradványok bedolgozására is szolgál. A mélyebb rétegekben végzett müvelés durvább talajszerkezetet alakít ki, kötött talajokon több menetre is szükség lehet. Sekélyen végzett müvelésre alkalmasak a tárcsák és kultivátorok. A folyamatosan sekély rétegben végzett művelés tömörödést okozhat, ezért a szántás nélküli rendszerekben is fontos a müvelési mélység változtatása. 
A mulcshagyó müvelés is a teljes felületre kiterjedő, forgatás nélküli megoldás. A szármaradványok részben a talajba kerülnek, részben a felszínen maradnak. A mulcs segít megőrizni a talajnedvességet, hatásosan védi a talajt a nyári klímakárok, illetve a heves záporok ellen, és segíti az eróziós károk elkerülését (Birkás, 2008).

Bakhátas müvelés során a vetés előtt 15-25 cm magas bakhátakat alakítanak ki, ebbe vetik a növényeket. Elsősorban széles sorközü szántóföldi növényeknél és néhány kertészeti kultúránál használt müvelésmód. A bakhátak későbbi magasítása mechanikai gyomirtást jelent, a bakhátak közt elhelyezett tarlómaradványok pedig vízmegtartó és taposási kárt csökkentő szerepet töltenek be (Birkás, 1997).

Precíziós gazdálkodás esetén az RTK-jel pontossága lehetővé teszi a széles sortávú növénykultúrák soraira fókuszáló müvelést. A sor és sorköz már alapmüveléskor történő megkülönböztetésével nem szükséges a teljes talajfelület megmunkálása, helyette az úgynevezett sávművelés használható, ami a talajfelület $\mathrm{kb}$. harmadán történik. A sávmüvelést a helyspecifikus dózisvezérléssel kombinálva az alapmüveléskor kijuttatott mütrágya oda és olyan mennyiségben kerül, ahogy arra a növénynek szüksége van (KITE, 2015). A tapasztalatok szerint (Husti, 2015) azonban ehhez csak a kiváló minőségü granulátumok jöhetnek szóba.

A vetőkultivátoros vetést általában alapmüvelésben nem részesített területen végzik. Vetéskor a talajmüvelés a teljes felületen, a vetés mélységéig történik. Elsősorban szárazabb területeken, nagy táblákon ajánlott, ha a talaj a $10 \mathrm{~cm}$ alatti rétegekben nem tömörödött (Birkás, 1997).

A direktvetés során a vetőmag külön alapmüvelés és magágykészítés nélkül, közvetlenül a tarlóba kerül. A magvakat keskeny magágyba vagy hasítékba juttatják, így a beavatkozás csak a talajfelszín 10 százalékát érinti (Birkás, 1997; Husti, 2015). A direktvetés hátrányaként említhető, hogy a mechanikai gyomszabályozás háttérbe szorul, a növényi maradványok bomlása lassabban következik be, a kártevők és a szármaradványokkal terjedő kórokozók felszaporodása veszélyesebb. Ezeket a problémákat a jó vetésforgó alkalmazásával és kémiai növényvédelemmel lehet megoldani. A kevésbé bolygatott talaj viszont jobban megörzi a csírázáshoz szükséges nedvességet, a tarlómaradványok pedig védelmet biztosítanak az erózió ellen.

Erózió által veszélyeztetett domboldalakon régóta használt módszer a rétegvonalak mentén történő mủvelés. A területről készített domborzatmodell és a müholdas navigáció ennek végrehajtását jelentősen segíti (lásd 1.3.2. fejezet). 



\section{A precíziós növénytermesztés elterjedtsége}

\subsection{Kezdetek}

A precíziós mezőgazdaság fogalma sokak előtt még ma is ismeretlen, pedig az ezzel kapcsolatos kutatások több évtizede folynak. A táblán belüli heterogenitást figyelembe vevő helyspecifikus gazdálkodás kezdetét néhány szerző már az 1920-as évekre teszi (Franzen és Mulla, 2015). A mai értelemben vett precíziós mezőgazdasági kutatások az 1980-as években kezdődtek a hozammérő eszközök, szenzorok, a változtatható mennyiségü kijuttatás és a helymeghatározó rendszerek fejlesztésével. A műholdas helymeghatározás, a térinformatika és távérzékelés, valamint a szenzortechnológiák fejlődésével alkalmazása egyre terjedt. Az első nemzetközi konferenciát 1992-ben rendezték az Egyesült Államokban, majd 1999-ben nemzetközi tudományos folyóirat is indult Precision Agriculture címmel (Yang és Lee, 2013).

Alkalmazása Magyarországon is több mint másfél évtizedes múltra tekint vissza: 1999-ben jött létre Mosonmagyaróváron a „Precíziós növénytermesztési módszerek” Doktori Iskola és megjelentek az új technológiával kapcsolatos első hazai publikációk (Győrffy, 2000; Neményi et al., 2001; Tamás, 2001).

A technológia szélesebb körü hazai megismeréséhez hozzájárult az NKFP kutatási program által támogatott, több egyetem és kutatóintézet együttmüködésével megvalósított kutatás, illetve az eredményeket bemutató A precíziós mezőgazdaság módszertana címü könyv (Németh et al., 2007).

A gyakorlat szempontjából ki kell emelni, hogy az IKR Rt. 2001-ben már 1000, 2002-ben pedig 1600 hektáron készített kukorica-, szója-, búza- és árpahozamtérképet, és e területeken differenciált mütrágya-kijuttatást is végzett (Molnár és Pecze, 2002), a precíziós tápanyag-utánpótlási szaktanácsadó rendszeréért pedig 2008-ban Innovációs Díjban részesült.

\subsection{Jelenlegi helyzet}

A precíziós gazdálkodás elterjedtsége nem egyforma a világ minden részén. Irodalmi források alapján az elterjedését egyaránt befolyásolják a társadalmi-gazdasági tényezők, az agroökológiai adottságok, technológiai, szervezeti és emberi tényezők, valamint a rendelkezésre álló információk. Általában a nagyobb területtel rendelkezö, fiatal, magasabb iskolai végzettségű, tőkeerős gazdálkodók alkalmazzák szívesen az új technológiákat (Bernardi és Inamasu, 2014; Fountas et al., 2005; Antolini et al., 2015; DEFRA, 2013). Elsősorban a szántóföldi termesztésben elterjedt, zöldség- és gyümölcstermesztésben, valamint állattenyésztésben még kevésbé alkalmazott.

A helyzet pontos értékelése nehézkes, mert sehol nincs ezzel kapcsolatos rendszeres adatgyüjtés. A kérdőíves felméréseknél jellemzően kicsi a válaszadási arány, így a szakirodalomban olvasható értékelések is általában kis mintákon alapulnak. A kis minták gyakran azért sem tekinthetők reprezentatívnak, mert a felmérések egy részét online kérdőívekkel végzik, amit eleve a számítógépet használó, innovatív gazdák töltenek ki nagyobb arányban. További probléma, hogy a felmérések során nem egységes a precíziós gazdálkodás elemeinek definiálása, csoportosítása.

\subsubsection{Világ}

A precíziós gazdálkodás elsőként az USA-ban, Európában és Ausztráliában terjedt el, majd Argentínában, Brazíliában és néhány ázsiai országban is elfogadottá vált (Fountas et al., 2005). Jelenleg az USA piaci részesedése a legnagyobb, közel 50 százalék (BIS Research, 2016), ahol a magas munkaerőköltség is ösztönzi a technológia terjedését. De itt a legnagyobb az állami támogatott- 
sága is, az USA mezőgazdasági minisztériuma (United States Department of Agriculture, USDA), a Nemzeti Repülési és Ürhajózási Hivatal (National Aeronautics and Space Administration, NASA) és a Nemzeti Óceáni és Légköri Hivatal (National Oceanic and Atmospheric Administration, NOAA) is hozzájárul a nagyüzemi precíziós gazdálkodás terjedéséhez (Technavio, 2015).

Amerikában a technológiák közül kezdetben a hozamtérképezés és a differenciált mütrágyakijuttatás volt a leginkább elterjedt, jelenleg az automatikus kormányzásé a legnagyobb piaci részesedés. A szója- és kukoricatermesztők már 2006-ban a területek több mint 40 százalékán végeztek hozamtérképezést, differenciált kijuttatást pedig 8 , illetve 12 százalékos arányban alkalmaztak. Öszi búza esetén 2009-ben a területek 35 százalékán végeztek hozamtérképezést és 14 százalékán differenciált kijuttatást (Schimmelpfenning és Ebel, 2011). A precíziós technológiák használata azonban más növényeknél is elterjedt. Az USDA adatai szerint a rizstermesztő gazdaságok 53 százaléka használt jármü-navigációt, 18 százaléka hozamtérképezést, 16 százaléka differenciált műtrágya-kijuttatást és 12 százaléka helyspecifikus talajtérképezést 2013-ban. Ugyanekkor a földimogyoró-termesztők körében a jármü-navigáció csak 42 százalék volt, de nagyobb arányban használtak talajtérképezést (25 százalék) és differenciált mütrágyázást (22 százalék).

Erickson és Widmar (2015) az amerikai mezőgazdasági inputanyag-kereskedők körében végzett felmérést a precíziós technológiákról. Felmérésük szerint legnépszerűbb az automatikus kormányzás, aminek alkalmazása már meghaladja a hagyományos sorvezetőkét, és szintén kedvelt a differenciált mütrágya-kijuttatás (1. ábra). Az utóbbi években a légi és müholdfelvételek, a térképi alkalmazások és a GPS logisztikai felhasználása is növekvő tendenciát mutat.

\section{1. ábra: A precíziós technológiák becsült piaci aránya az Amerikai Egyesült Államokban, az inputanyag-kereskedők körében végzett felmérés alapján}

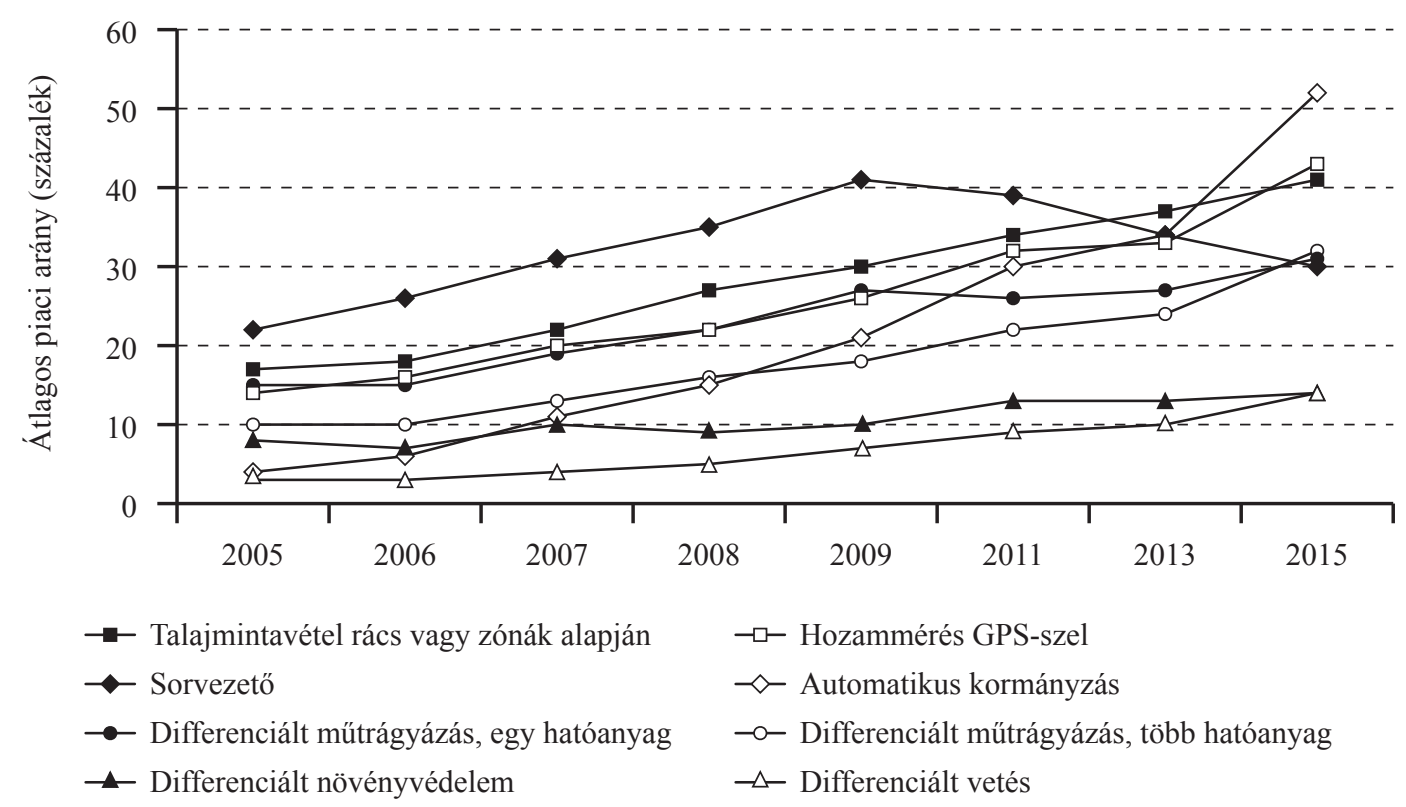

Forrás: Erickson és Widmar, 2015

A kereskedők 82 százaléka válaszolta, hogy precíziós technológiai szolgáltatásokat is nyújtanak az ügyfeleik számára. Ezek közt leggyakoribbak - a kereskedők több mint 60 százaléka végzi - a differenciált mütrágya-kijuttatás tervezése és a GPS-es talajmintavétel. Szintén jelentős (50 százalék feletti) a differenciált mészkijuttatásban, a terület feltérképezésében és a hozamtérképek kiértékelésében nyújtott segítség aránya. Az előző, 2013-ban végzett felméréshez képest a legnagyobb 
növekedést (26 százalék) a változó tőszámú vetés tervezése mutatta, amivel így már a kereskedők fele foglalkozik.

A nebraskai egyetem felmérése szerint (Castle et al., 2015) a gazdálkodók 75 százalékban rács alapján végzik a talajmintavételt. A precíziós technológiák közül leginkább a hozamtérképezés és a GPS-alapú navigáció terjedt el, ezeket a gazdálkodók több mint 80 százaléka használja. Ezt követi a kijuttatási térképek készítése és a differenciált kijuttatás (68 százalék), míg a mühold- vagy légi felvételek (30 százalék), illetve a növényszenzorok alkalmazása ( $<10$ százalék) még kevésbé elterjedt.

Argentínában gyorsan terjed a precíziós technológia és nagy területeken alkalmazzák. A 33 millió ha vetésterület 21,6 százalékát müvelik precíziós módszerekkel. Nagy arányban alkalmaznak vetésellenőrző monitorokat, sorvezetőket és hozamtérképezést, az automatikus kormányzás még kevésbé elterjedt (INTA, 2013).

Brazíliában elsősorban a szója és kukorica ( 82 százalék), illetve a búza (22 százalék) és bab (13 százalék) termesztésében terjedt el. Bernardi és Inamasu (2014) szerint a gazdálkodók nem használják ki a meglévő precíziós gépeiket, átlagosan csak a területük 65 százalékán használják. A jármünavigáció (sorvezető 42 százalék, automatikus kormányzás 37 százalék), valamint a differenciált kijuttatás (vetés és műtrágyázás 49,4 százalék) a leggyakrabban alkalmazott technológia, hozamtérképezést csak 19 százalékban végeznek.

Ausztráliában a gabonatermelők 20 százaléka végzett precíziós termesztést 2012-ben (OECD, 2016), de a nagy területen gazdálkodók körében jóval nagyobb ez az arány. LLewellyn és Ouzman (2014) felmérése alapján az 500 ha feletti gabonatermelők 77 százaléka használ automatikus kormányzást és 33 százalék végez hozamtérképezést. A termelők 35 százaléka rendelkezik differenciált kijuttatásra alkalmas géppel, de csak 15 százaléka használja. A technológiák eredményességére utal, hogy a felhasználók közül 94 százalék ajánlaná másoknak az automatikus kormányzást, 77 százalék a hozamtérképezést és 80 százalék a differenciált mütrágyázást.

\subsubsection{Európa}

Az EU28-tagországok az USA és Ausztrália után a harmadik helyet foglalják el a precíziós mezőgazdaság piacán. A nem EU-tagok (Norvégia, Svájc, Ukrajna és Oroszország) - elsősorban az utóbbi két ország révén - is jelentős piaci értéket képviselnek, az EU28-országokhoz képest több mint fele összeget (BIS Research, 2016). Ennek legfőbb oka a gazdaságok méretében mutatkozó különbségek - míg a nyugat-európai (elsősorban a francia és olasz) gazdaságok sokkal kisebbek, mint az amerikaiak, az ukrán és orosz gazdaságok általában nagyméretủek, a hatékony gazdálkodás következtében a befektetés hamarabb megtérül (Maler, 2015).

Az Európai Ürügynökség (European Space Agency, ESA) vezetésével kidolgozott TalkingFields rendszer is a precíziós gazdálkodás támogatására jött létre, 2009-től német és orosz nagybirtokokon kezdték alkalmazni (ESA, 2010). Azóta több országban, köztük Magyarországon is elérhető. Segítségével $20 \times 20$ méteres felbontásban kaphat a gazdálkodó a terület heterogenitását mutató alaptérképet, a talajvizsgálathoz felhasználható zónatérképet, valamint őszi búza, cukorrépa és kukorica esetén biomasszatérképet.

Az EU és Ukrajna között 2015 januárjában együttmüködési megállapodás született a globális müholdas navigációs rendszer (GNSS) terén. Ennek értelmében az EGNOS-korrekció használatát egész Ukrajnára kiterjesztették, ami jelentősen segíti a precíziós gazdálkodást is. Ukrajna lehetőségeit a Deere\&Company mezőgazdasági gépforgalmazó is felismerte, és együttmüködési megállapodást írtak alá az ukrán mezőgazdasági és élelmezésügyi miniszterrel a precíziós gazdálkodás terjesztésére (MINAGRO, 2015). 
Az Európai Mezőgazdasági Gépforgalmazók Szövetsége szerint (CEMA, 2014) az utóbbi tíz évben a precíziós gazdálkodás jó gyakorlattá vált. Az új mezőgazdasági gépek 70-80 százaléka rendelkezik valamilyen precíziós képességgel, a monitorok és vezérlök integrációja pedig segíti az egyszerü és költséghatékony felhasználást.

Országonként csak kevés adat áll rendelkezésre a precíziós technológiák alkalmazásáról. Angliában egy 2012-es felmérés szerint (DEFRA, 2013) a gazdálkodóknak csak 22 százaléka használt GPS-es jármü-navigációt, 20 százalék talajtérképezést, 16 százalék differenciált kijuttatást és 11 százalék hozamtérképezést. Németországban csak 11 százalék volt a precíziós gazdálkodók aránya 2006-ban (OECD, 2016), míg Franciaországban a gazdálkodók 25,4 százaléka használt GPS-t 2013-ban (Vigani et al., 2015). Az EurActiv (2016) frissebb adata szerint Franciaországban 150000 hektáron folytatnak precíziós gazdálkodást, és a gazdaságok felében van monitorral felszerelt traktor.

Az innovációk elterjedése kapcsán gyakran használják a Gartner-féle hiperciklus görbét. Egy új technológia megjelenése általában fokozott érdeklődéssel jár, majd a gyakran túlzott elvárások miatt az érdeklődési csúcs után szinte törvényszerüen egy időszakos kiábrándultság következik. A technológia finomítása után annak alkalmazhatósága javul, a kockázatok helyett az előnyök kerülnek előtérbe, ami a termelésben való elterjedéséhez vezet. A precíziós mezőgazdaság elemeit Blackmore (2016a) a 2. ábra szerint helyezi el e görbén. A jármü-navigáció, a hozamtérképezés és a helyspecifikus talajmintavétel már elfogadottnak tekinthető a gyakorlatban, a munkagépkormányzás, a differenciált vetés és az automatikus szakaszvezérlés is egyre terjed. Az érdeklődési csúcson jelenleg a drónok állnak, a kutatók pedig a robotok fejlesztésére, valamint a növényfejlődési modellek integrációs lehetőségeire fókuszálnak.

\section{2. ábra: A precíziós technológiák helye a Gartner-féle hiperciklus görbén}

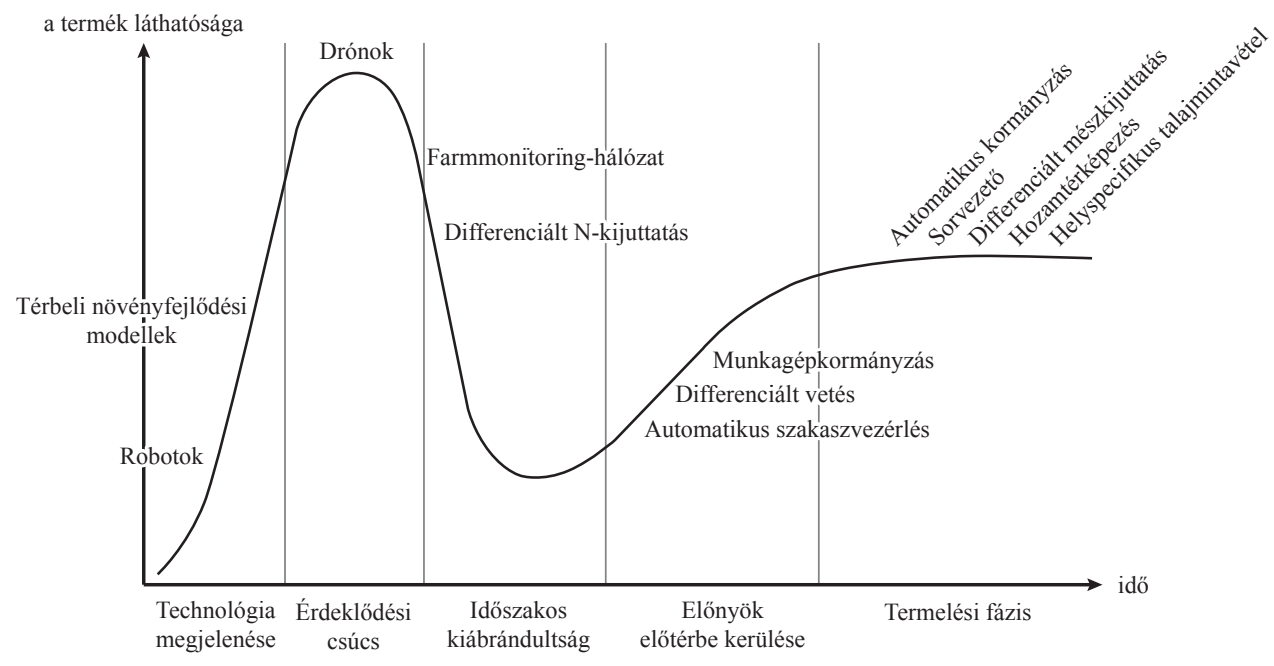

Forrás: Blackmore, 2016a

\subsubsection{Magyarország}

A precíziós gazdálkodás Magyarországon is több mint másfél évtizede megjelent, ugyanakkor sokak előtt még ma is ismeretlen fogalom. Az Agroinform.hu és a Market Insight 2015-ös felmérése szerint (Tóth, 2015) a szántóföldi növénytermesztőknek csak a fele hallott már róla, de ez az arány függ a gazdaság méretétől. Az 500 hektár feletti nagy gazdaságok döntéshozói körében 88 százalék, a 100 és 500 hektár közötti közepes gazdaságoknál 67 százalék, míg a 100 hektár alatti kis gazdaságoknak csupán egyharmada hallott már precíziós gazdálkodásról. 
Lencsés et al. (2014) felmérése szerint a precíziós gazdálkodást alkalmazók elsősorban a 40 évnél fiatalabb, felsőfokú végzettséggel rendelkező, 300 hektárnál nagyobb területen gazdálkodók, ami egyezik a nemzetközi tapasztalatokkal.

Vigani et al. (2015) szerint a magyar gazdálkodók 23,4 százaléka használt GPS-t 2013-ban. Az AgroStratéga felmérése alapján a GPS-t használó gazdálkodók aránya 2015-ben már 44 százalék volt, de a 40 évnél fiatalabb korosztályban ez eléri a 48 százalékot (Pólya és Varanka, 2015). Lencsés et al. (2014) szerint azonban olyan gazdálkodók is használnak GPS-es jármü-navigációt vagy talajmintavételt, akik nem tekinthetők igazán precíziós gazdálkodónak, mert nem használnak olyan technológiákat, amik helyspecifikus, differenciált kezelésekhez vezetnek.

A pontos jármü-navigációhoz szükséges RTK-korrekciót elsőként a Földmérési és Távérzékelési Intézet (FÖMI) kezdte szolgáltatni 2010-ben. Később további szolgáltatók jelentek meg a piacon: a KITE Zrt., az AXIÁL Kft., a Geotrade Kft. (jelenleg Geotools Europe GNSS Kft.), valamint az Agromatic Kft. A cégektől kapott adatok alapján a precíziós mezőgazdasági felhasználók száma 2500 körülire tehető.

A technológiák közül - a publikált felmérések, valamint a KITE Zrt. és az AXIÁL Kft. információi alapján - a helyspecifikus talajmintavétel, a sorvezetők alkalmazása, valamint egyre nagyobb mértékben az automatikus kormányzás vált a gyakorlat stabil elemévé. A differenciált mütrágyakijuttatás és a hozamtérképezés helyzetéről megoszlanak a tapasztalatok. Az Informatikai, Távközlési és Elektronikai Vállalkozások Szövetsége (IVSZ, 2016a) adatai alapján a precíziós gazdálkodók több mint fele alkalmaz sorvezetőt, 30 százalék körüli a robotpilóta alkalmazásának aránya, majd ezt követi a munkagépvezérlés, a vetés és a tápanyag-kijuttatás (25 százalék). A növényvédelmi szenzorok és drónok, valamint a precíziós öntözés egyelőre az érdeklődési szakaszba sorolhatók, alkalmazásuk aránya csak 5 százalék körüli.

A jelen tanulmányhoz kapcsolódó kérdőíves felmérés részletes eredményeit a 6 . fejezet mutatja be.

A precíziós gazdálkodás hazai terjedéséhez egyre több gép-, eszköz- és inputanyag-forgalmazó hozzájárul. Meghatározó szerepü az IKR Agrár Kft., amely több mint 10 éves tapasztalatra támaszkodva elsősorban a talajmintavétel és a tápanyag-utánpótlási szaktanácsadásra fókuszál. A KITE Zrt. is közel egy évtizede folytat kutatási, a gyakorlatban történő adaptálási és szaktanácsadási munkát. Komplex szaktanácsadási rendszerüket - informatikai háttér, agrotechnológia, műszaki megoldások - 2015-ben indították. Az AXIÁL Kft. 2015-ben kapott Hazai Termékfejlesztési Nagydíjat a mAXI-NET gépmárkafüggetlen RTK-korrekciós hálózatáért, és jelentős szerepe van a GPSeszközök és precíziós mezőgazdasági gépek forgalmazásában. A precíziós gazdálkodással kapcsolatos oktatás és szaktanácsadás hazai helyzetéről a 9.1.5. fejezet ad részletes áttekintést.

\subsection{Várható jövő}

A növekvő népesség nagyobb élelmiszerigénye, a mezőgazdasági területek csökkenése, valamint a vízhiány miatt egyre hatékonyabb termesztési módokra van szükség, és ez a precíziós gazdálkodás gyors terjedését segítheti elö. A technológiák terjedésére vonatkozóan több nagy piackutató cég próbál elörejelzést adni.

\subsubsection{Nemzetközi trendek}

Az egyik legnagyobb piackutató cég, a MarketsandMarkets (2016) jelentése szerint 2020-ig évente átlagosan 11,7 százalékos növekedés várható a precíziós gazdaság piacán, ami 2020-ra elérheti a 4,8 milliárd dollárt. Hasonló, évi 12 százalékos növekedést vár 2020-ig a Roland Berger (Dressler et al., 2015). Kicsit nagyobb növekedést jelez a BIS Research (2016), becslésük szerint 2016 és 2022 
között évente átlagosan 12,7 százalékkal nőhet a precíziós gazdálkodás piaca, és forgalma 2022-re elérheti a 7,6 milliárd dollárt, míg a Technavio (2015) évi 14 százalékos növekedést vár 2019-ig.

Jelenleg Észak-Amerikában a legnagyobb a precíziós ágazat bevétele, és a következő években további növekedés várható. Második helyen az ázsiai és csendes-óceáni térség áll, amely magában foglalja Ausztráliát, Indiát és Kínát is, ahol kiemelkedő jelentőségű a mezőgazdaság. A térség fejlődő országaiban az átlagosnál nagyobb növekedés várható a precíziós gazdálkodás terén. Legkisebb növekedés a dél-amerikai, illetve a közép- és kelet-afrikai régióban várható.

A European GNSS Agency (2015) szerint 2023-ra a nagy teljesítményű traktorok 50 százalékában lesz navigációs rendszer világszerte. Az alkalmazások nagy részét a jövőben is az automatikus kormányzás jelenti majd, de a gazdálkodók nagyobb arányban fordulnak a további megoldások (pl. differenciált kijuttatás) felé (3. ábra).

\section{3. ábra: A GNSS-eszközök alkalmazásának változása}

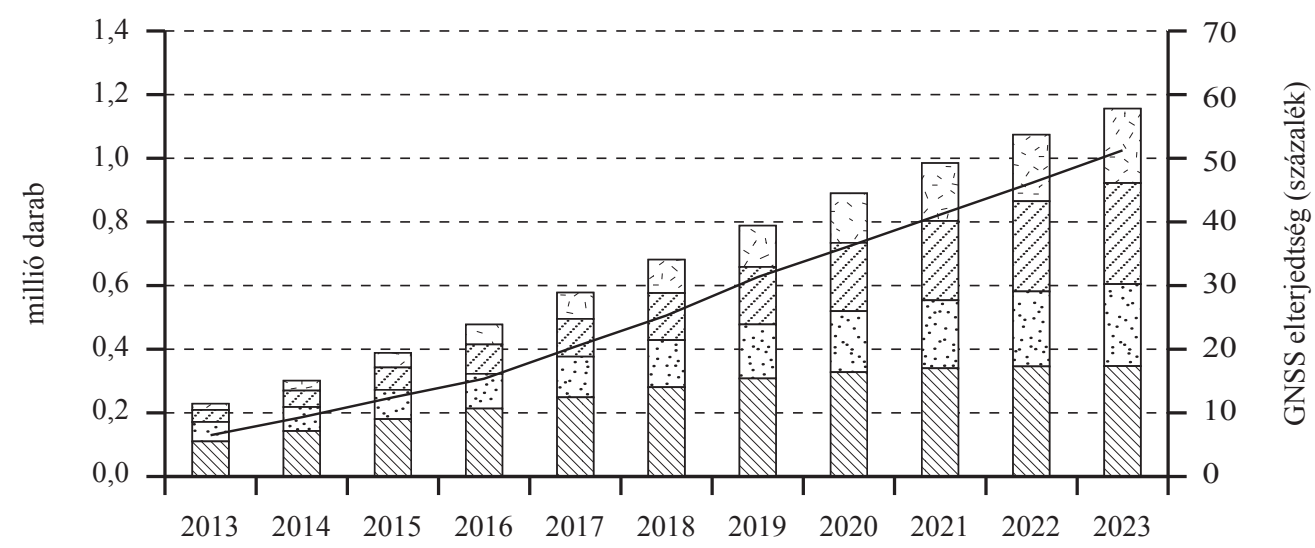

MU Traktorirányítás 2 Differenciált kijuttatás $\therefore$ Automatikus kormányzás
$\therefore \therefore$ Flottakövetés — GNSS-elterjedtséga)

a) A GNSS-elterjedtség a GNSS-eszközzel felszerelt, nagy teljesítményủ traktorok arányát jelenti.

Forrás: European GNSS Agency, 2015

A rendelkezésre álló vízforrások korlátozottsága miatt a precíziós öntözés jelentősége is növekszik. A BIS Research (2015) szerint 2020-ig évente átlagosan 7,2 százalékkal nőhet a piaci részesedése. E tekintetben is Észak-Amerikáé a vezető szerep, majd ezt követi az ázsiai és csendes-óceáni térség, ami a világ öntözött területeinek 60 százalékát teszi ki.

A drónok (UAV-ok) egyaránt használhatók a talajadottságok és a növényállomány felmérésében, valamint a legeltetett állatok ellenőrzésében. Helyettesíthetik a terepi felvételezést, ezzel időt és pénzt lehet megtakarítani. Az áruk a közeljövőben várhatóan csökkenni fog, ezzel az alkalmazásuk általánosabbá válhat, ha a szabályozási problémák megoldódnak.

A magas beszerzési és fenntartási költségek miatt jelenleg a hardvereszközök (GPS/GNSS készülékek, érzékelők, kijelzők) adják a piaci érték mintegy 85 százalékát (BIS Research, 2016), a jövőben a szoftverek piaci részesedésének növekedése várható (MarketsandMarkets, 2016). A menedzsmentrendszerek terén a jelenlegi érték megkétszereződését várják a piackutatók 2022-re.

Erickson és Widmar (2015) felmérése szerint a kereskedők 2018-ig a különböző precíziós technológiák elterjedésében 10-16 százalékos növekedést várnak az USA-ban. A szolgáltatások terén elsősorban az UAV-eszközökkel kapcsolatban (19 százalékos), valamint a differenciált növényvédelem (11 százalék) és vetés ( 9 százalék) terén végzett szaktanácsadásban számítanak növekedésre. 
A precíziós technológiák fejlődése során további automatizálás és az alkalmazások összekapcsolódása várható. Ez kihat a mezőgazdasági értéklánc egészére, és új üzleti lehetőségeket nyújt például a szaktanácsadás, az adatelemzés és a modellezés terén (Dressler et al., 2015, 4. ábra).

\section{4. ábra: A technológiák változása 2010-2030 között}

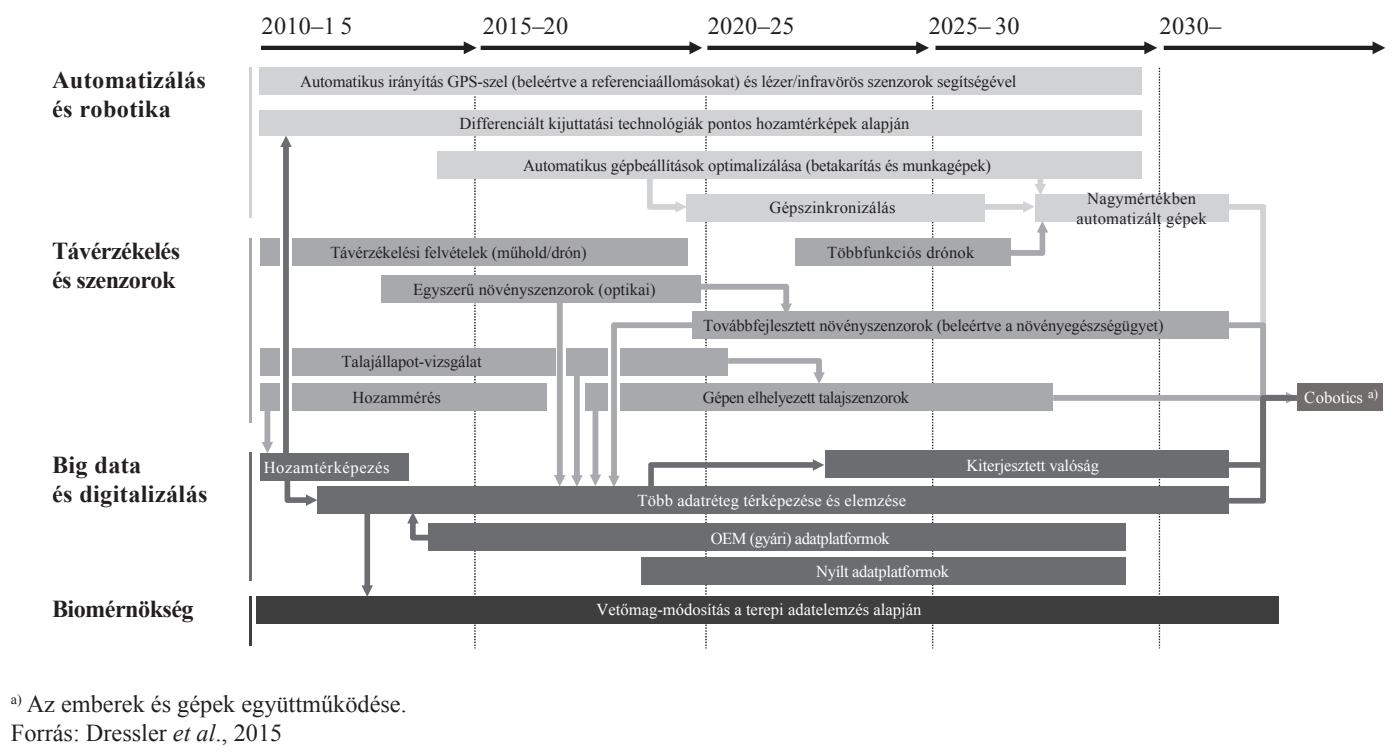

\subsubsection{Európa}

Európa különösen nagy erőfeszítéseket tesz az inputanyagok hatékony felhasználása és a környezetkímélő agrotechnikai módszerek alkalmazása érdekében, aminek egyik lehetősége a precíziós mezőgazdaság. Az Európa Parlament Tudományos és Technológiai Lehetőségek Értékelése testülete (STOA, 2016) szerint két fontos trend figyelhető meg az európai mezőgazdaságban: a gazdaságokban dolgozók számának csökkenése, illetve az átlagos üzemméret növekedése. Ezek a trendek is kedveznek a precíziós technológia terjedésének, feltéve, hogy a pénzügyi lehetőségek és az ismeretek/ készségek azt nem korlátozzák. A gazdálkodók 70 százalékának azonban csak gyakorlati ismeretei vannak, mezőgazdasági szakképzettsége nincs, az ő körükben a technológia lassabb terjedése várható. Az EU-n kívüli országokat tekintve a nagy mezőgazdasági területe miatt jelentős piaci potenciált jelent Ukrajna és Oroszország.

A Boston Consulting Group (Corsini et al., 2015) felmérése szerint a francia, német, lengyel és angol gazdálkodók 60 százaléka úgy gondolja, hogy a precíziós gazdálkodás széles körben elterjedt lesz 2030-ra.

A GPS/GNSS készülékek árcsökkenése kulcsfontosságú a precíziós gazdálkodás terjedésében. A készülékek száma 2022-re a jelenlegi közel háromszorosára nőhet, ami elsősorban az automatikus kormányzás és a differenciált kijuttatási technológia elterjedéséhez járul hozzá (BIS Research, 2016). Más becslések szerint 2020-ra az európai traktorok 35 százalékában lesz GNSS-eszköz, és jelentős növekedést várnak a közép- és kelet-európai országokban, ahol jelenleg kicsi ennek az elterjedtsége (Zarco-Tejada et al., 2014).

Jelenleg az érdeklődési csúcson a drónok alkalmazása áll, de a felvételek felbontásának javulásával egyre nagyobb lehetőség rejlik a müholdas távérzékelésben is. Az EU Copernicus programjának keretében 2015-ben pályára állított Sentinel-2A, valamint a 2016 öszére tervezett Sentinel-2B 
földmegfigyelő műholdak csak 10-20-60 m terepi felbontású multispektrális képeket készítenek, de együtt ötnapos visszatérési időt biztosítanak és ingyenesen elérhetők. A 10 m felbontás - elsősorban nagy táblákon - a precíziós mezőgazdaság egyes területein is megfelelö lehet (Zarco-Tejada et al., 2014; Zboray, 2016).

A Copernicus program ingyenes adataira épül az EU által finanszírozott APOLLO Projekt is, amelyben öt ország - Görögország, Spanyolország, Ausztria, Belgium és Szerbia - vesz részt. A 2016-2019 során megvalósítandó projekt célja egy piacképes precíziós mezőgazdasági szaktanácsadási rendszer kialakítása, ami elsősorban, de nem kizárólagosan a kistermelőkre fókuszál. A szolgáltatások négy területet érintenek: talajmüvelés, öntözés, növénymonitoring és termésbecslés. A rendszer müködését három pilotterületen vizsgálják: Görögországban, Szerbiában és Spanyolországban.

A precíziós gazdálkodás során keletkező nagy mennyiségű adat miatt növekedni fog a vállalatirányítási rendszerek iránti kereslet (Fountas et al., 2015).

\subsubsection{Magyarország}

A 2015-ös felmérés szerint (Tóth, 2015) a precíziós eszközöket már alkalmazó gazdálkodók 20 százaléka egy éven belül, 61 százaléka pedig 3 éven belül további beruházást tervez valamely precíziós technológiába, elsősorban automata kormányzás, vetőgép, sorközművelés, tápanyaggazdálkodás, valamint öntözés területén. Azok körében, akik még nem használnak precíziós eszközöket, a többség (43 százalék) bizonytalan a technológia bevezetésével kapcsolatban, 31 százalék pedig nem tervez precíziós beruházást három éven belül. A gazdálkodóknak csupán 5 százaléka egy éven belül, míg 21 százaléka három éven belül tervezi precíziós technológia, főként precíziós talajmüvelés, vetés és differenciált tápanyag-kijuttatás bevezetését.

Az IVSZ (2016a) felmérése szerint is szívesen vennének igénybe a gazdálkodók az informatikai fejlesztésekre vonatkozó beruházási támogatást, elsősorban a tápanyag-kijuttatás (65 százalék), a munkagép-vezérlés, a vetés és a növényvédelmi szenzorok esetén.

Az MTA elnöksége által elfogadott Nemzeti Víztudományi Kutatási Program kapcsán Tamás (2016) kiemelte, hogy a precíziós mezőgazdaság technológiai elemei adottak, de fontos lenne, hogy a szakma és a termelők is ismerjék ezeket a vízgazdálkodás szempontjából hatékony, víz- és energiatakarékos öntözési megoldásokat.

A Földművelésügyi Minisztérium a 2016-2050-es élelmiszer-gazdasági stratégiájában (FM, 2016) is arra számít, hogy a közeljövőben általánossá válik az intenzív precíziós gazdálkodási technológiák alkalmazása, ami az öntözésfejlesztési beruházásokkal együtt lehetőséget ad a szántóföldi növénytermesztés termésbiztonságának maximalizálására. 


\section{A szántóföldi precíziós gazdálkodás közgazdasági hatásai}

A hagyományos szántóföldi növénytermesztésről a precíziós gazdálkodásra történő áttérés a termelés szempontjából jelentős változásokat eredményez, melyek természetesen a gazdaságok jövedelmezőségét is befolyásolják. A precíziós növénytermesztés gazdasági következményeiröl megoszlanak a vélemények, hiszen a technológia hatása számos tényezőtől függ. Rendkívüli mértékben befolyásolja az alkalmazás eredményességét a vetésterület talajadottságának heterogenitása, a gazdálkodó és az alkalmazottak szaktudása és hozzáállása (Lencsés et al., 2014).

A szakirodalmak többsége utal rá (Lencsés et al., 2014; Sinka és Mesterházi, 2014; EIP-Agri, 2015; Bora et al., 2012; Schieffer és Dillon, 2014), hogy a precíziós technológia az inputanyagfelhasználás optimalizálásán, a munkaerö-felhasználás csökkenésén keresztül a termelési költségre gyakorol pozitív hatást. Mindemellett nő az egy hektárra jutó termés mennyisége és javul a minősége, csökken a hozamingadozás. A kisebb mértékü inputanyag-felhasználásból eredő termelésiköltség-csökkenés és a hozamnövekedés hatására javul a jövedelmezőség. Ugyanakkor a szakirodalmak között vannak olyan kutatási eredmények is, amelyek az egyes precíziós technológiai alkalmazások mellett inputanyag- és többletmunka-ráfordításról számolnak be (Lencsés et al., 2014; Schieffer és Dillon, 2014; Sinka és Mesterházi, 2014). A későbbiekben az eltérő álláspontok oka is részletesen kifejtésre kerül.

A precíziós gazdálkodásra való áttérés jelentős beruházási költséggel jár. A gazdák számára nehéz megítélni egy új technológia alkalmazhatóságát és annak előnyeit, egyértelmü költség-haszon adatok birtokában azonban könnyebben hoznak meg ilyen jelentős beruházási döntést. Amennyiben a precíziós gazdálkodásnak bizonyítottan alapvető gazdasági, környezeti előnyei vannak, az nagymértékben elősegíti a technológia elfogadását a gazdálkodók számára. Több olyan kutatás is megjelent, amely az új technológiához szükséges beruházás gazdaságosságát vizsgálja, illetve a többletráfordítás megtérüléséhez megfelelö üzemméretet határozza meg. A szakirodalmak szerint a meglévő költség-haszon elemzési rendszerek között kevés az alapvetően felhasználóorientált kutatás, az alkalmazott és részletes elemzés. A precíziós gazdálkodás bevezetésének döntéshozatalához, ezáltal a technológia elterjedéséhez szükséges a helyspecifikus gazdálkodásból származó haszon kimutatása (EIP Agri Focus Group, 2015). A beruházás megtérülési idejének meghatározása viszont korántsem egyszerü, hiszen elsődlegesen a technológiából fakadó jövedelemtöbbletet kell megállapítani, amelyet számos a fentiekben már említett tényező befolyásol. Figyelembe kell venni az elemzések során, hogy minden növénykultúrának eltérőek a költség-jövedelem viszonyai, ezáltal külön kell meghatározni az életképes üzemméretet a termesztett növényekre. A termőföld minősége és a termöhely adottságai szintén befolyásoló tényezők, melyeket ugyancsak figyelembe kell venni a szükséges minimális gazdaság méretének meghatározásakor (Kalmár, 2010).

A továbbiakban a korábbi kutatások során végzett számítások eredményeivel szemléltetjük a precíziós technológia közgazdasági és makrogazdasági hatásait, a beruházás megtérüléséhez szükséges időt és a szükséges üzemméretet.

\subsection{A precíziós növénytermesztés közgazdasági előnyei, hátrányai}

A gyakorlatban és a kutatásokban egyaránt megoszlanak a vélemények arról, hogy mikor beszélhetünk precíziós gazdálkodásról. A szakértők és a laikusok álláspontja egyaránt a technológiai elemek alkalmazásával függ össze. Vannak, akik az automata kormányzást folytató gazdaságokat is precíziós növénytermesztőknek tekintik, mások pedig kizárólag a differenciált módon megvalósult tápanyag-kijuttatást, a menedzsmentzónás müvelést végzőket sorolják precíziós gazdálkodók közé (Lencsés, 2013). A kutatás során azokat a szántóföldi növénytermesztő üzemeket tekintettük precí- 
ziós gazdálkodást folytatóknak, amelyek alkalmaztak legalább egy precíziós technológiai elemet. Ennek értelmében a vizsgáltak köre inhomogén csoportnak tekinthető, hiszen egyaránt tartalmaz menedzsmentzónás müvelést végzöket és olyan üzemeket, amelyek mindössze egy precíziós technológiai elemet használnak.

A továbbiakban az egyes technológiai elemek elterjedtségét és az azok használatából származó előnyöket, illetve hátrányokat szemléltetjük.

A növénytermesztésben használható precíziós technológia elemei a következők: automata kormányzás (egyes szakirodalmak robotkormányzásként említik), GPS-alapú irányítási rendszer (gépnavigáció), automatikus szakaszvezérlés, kijuttatás közben változtatható (vetőmag-, mütrágya-, növényvédőszer-) mennyiség, különböző applikációs térképek (például tápanyag-, növényvédőszer-, vetőmag-kijuttatási térkép), hozamtérképezés, hozammonitor, talajminta-vételezés, növényvédelmi és a távérzékeléses felvételezés. A leggyakrabban alkalmazott precíziós technológiai elemekről megoszlanak a vélemények a szakirodalomban. Kalmár (2010) és Castle et al. (2015) szerint a precíziós növénytermesztés első lépése a hozamtérképezés, azaz a betakarítás során nyert táblán belüli differenciáltságot tartalmazó hozamtérkép elkészítése, mely alapján megtervezhető a helyspecifikus tápanyag-utánpótlás. Ezt az elméletet támasztja alá a Nebraska-Lincoln egyetem (Castle et al., 2015) felmérése, amelyben a kitöltők több mint 80 százaléka alkalmazott hozamtérképezést. Ezen technológiai elem alkalmazásával a precíziós technológiai elemek eredményessége együttesen mutatható ki, viszont költségmegtakarítás közvetlenül nem jelentkezik a használat során, így a beruházás megtérülése nehezen kalkulálható. Hátránya továbbá, hogy többletmunka-ráfordítást és megfelelö szakértelmet igényel (Kalmár, 2010). A precíziós tevékenységek eredményességének kimutatása és a helyspecifikus anyagkijuttatáshoz biztosított térkép elönyeit személyes megkérdezésre alapozva hazánkban kevesen használják ki (Lencsés et al., 2014). A megállapítást viszont fenntartásokkal kell kezelni, mert ebben a felmérésben összesen 8 precíziós technológiát alkalmazó gazdaság képezte a vizsgált üzemek körét .

A precíziós technológiát használó magyar gazdálkodók körében a legnépszerübb művelet a helyspecifikus tápanyag-utánpótlás (Lencsés et al., 2014), ami nem meglepö, hiszen azonos dózis mellett a mütrágyamennyiség az átfedések kiküszöbölése révén csökken, ezzel együttesen az üzemanyag-felhasználás is mérséklődik, illetve amennyiben az üzem korszerü műtrágyaszóró géppel rendelkezik, ennek az elemnek a beruházásigénye a legkisebb (Kalmár, 2010). A precíziós tápanyagellátás további elönye, hogy technológiai oldalról tekintve minden szántóföldi növény esetén eredményesen alkalmazható eljárás (Takácsné, 2011).

A precíziós növényvédelem szintén a legelterjedtebb technológiai elemek közé tartozik Lencsés et al. (2014) felmérésében, azon belül is a gyomirtást végzik a legtöbben helyspecifikusan. A technológiának viszont árnyoldala is van, mégpedig hogy a helyspecifikus beavatkozásból származó előnyt nem lehet nagymértékben kihasználni, hiszen a permetezésnél a szórófejek akár 50 centiméteres átfedést is eredményezhetnek (Kalmár, 2010). A precíziós növényvédelemben, föként a gyomszabályozás alkalmazásával a széles sortávolságú növénykultúráknál érhető el érdemi vegyszer-megtakarítás (Takácsné, 2011).

A helyspecifikus talajmintavétel már kevésbé közkedvelt technológiai elem a magyar precíziós gazdálkodók körében (Lencsés et al., 2014), habár a talaj állapotáról begyüjtött adatok a beavatkozás szükségességéről és a precíziós tevékenységek eredményességéről is képet adnak. Ehhez speciális eszközállomány szükséges, amelyet a gazdálkodó szolgáltatásként is igénybe vehet. Magyarországi viszonylatban az utóbbi elterjedtebb (Kalmár, 2010).

A helyspecifikus technológia nyújtotta pontosságot a növénykultúrák vetésében is ki lehet aknázni, amely szintén inputanyag-megtakarítást eredményez azáltal, hogy segítségével képesek a gazdálkodók a területen belül változtatni a növénykultúrák tőszámát a vetés során, így a vetési távolság meghatározása teljes mértékben az adott körülményekhez alkalmazkodik (Kalmár, 2010). 
A technológiák együttes alkalmazása jelentős költségmegtakarítást eredményez, ám Lencsés et al. (2014) felmérése alapján Magyarországon kevesen használják ki a teljes technológia nyújtotta elönyöket, a vártnál alacsonyabb számban alkalmaznak egyszerre több precíziós technológiai elemet a növénytermesztés gyakorlatában.

A továbbiakban a precíziós gazdálkodás alkalmazásával üzemi szinten elérhető megtakarításokat taglaljuk.

A precíziós gazdálkodás célja a termesztéstechnológiák optimalizálásával a jövedelmezőség növelése. A cél eléréséhez sorra kell vennünk a technológiából származó elönyöket. Ahogy a fentiekben már említésre került, a precíziós növénytermesztés legfontosabb előnyei az inputanyag-felhasználás optimalizálása, azaz egy-egy meghatározott beavatkozás és dózis mellett a növényvédőszer-, a mütrágya-, a vetőmag- és a kijuttatáshoz szükséges üzemanyag-felhasználás csökkenése és ezzel összefüggésben az anyagköltség és a munkaerő mérséklődése. Az inputkereslet csökkenése árcsökkentő hatással is járhat (Takácsné, 2011). A kevesebb kijuttatott kemikália és vízfelhasználás következtében a növénytermesztés környezetterhelése is csökken (Weiss, 1996). A technológia további előnye a termelés nyomonkövethetőségének és a termés minőségének javulása, a hozamnövekedés, a hozamingadozás mértékének csökkenése és mindezek eredményeképpen a magasabb jövedelmezőség (Lencsés et al., 2014; Sinka és Mesterházi, 2014; EIP-Agri, 2015; Bora et al., 2012; Schieffer és Dillon, 2014). Wolf és Buttel (1996) szerint a precíziós gazdálkodás a termelés hatékonyságának növekedését és a környezetszennyezés mérséklődését eredményezi. Amellett, hogy a környezeti károkat csökkenti a precíziós gazdálkodás, termelői szinten a kockázatcsökkentés eszköze is (Auernhammer, 2001; Gandonou et al., 2004; Chavas, 2008). Néhány szakértő viszont a munkaerő növekedéséröl (Lencsés et al., 2014) és bizonyos esetekben a költségek emelkedéséröl (Schieffer és Dillon, 2014) számol be.

A precíziós technológia alkalmazásából származó megtakarítások számszerüsítését számos tényező befolyásolja. A költségcsökkenés mértéke függ a termelés intenzitásától és az eltérő talajadottságoktól. Továbbá hatással van rá az is, hogy a gazdálkodó miként optimalizálja a termelési szerkezetét, a hozamokat homogenizálni vagy heterogenizálni szeretné, azaz a rosszabb hozamú területeken magasabb hozamot szeretne elérni és ezáltal egységesíteni a táblán elérhető hozamokat, avagy az alacsony hozamtermő területeken alacsony intenzitással gazdálkodik vagy akár müvelési ágat is vált, míg a magas hozamokat akár tovább növeli.

A továbbiakban a precíziós gazdálkodásból származó inputanyag-csökkenés kimutatására végzett kutatások eredményeit szemléltetjük.

Sinka és Mesterházi (2014) a tápanyag-utánpótlásban nagyüzemi gyakorlatban vizsgálta a precíziós technológia hatását, amely során 15 százalékos megtakarítást tapasztalt a kijuttatott tápanyag mennyiségében. Lencsés et al. (2014) kutatása alapján a precíziós növénytermesztők hazánkban alátámasztották, hogy a precíziós technológiával jelentős mértékủ megtakarítás realizálható a tápanyag-utánpótlásban. Nemzetközi viszonylatban 30 százalékig terjedő mütrágya- és 20-60 százalékos növényvédőszer-megtakarításról számoltak be a precíziós tápanyag-utánpótlás hatására a talaj homogenitásától függően (Rider et al., 2006; Lowenberg-DeBoer és Swinton, 1997; Blackshaw et al., 2006). Az Amerikai Egyesült Államokban Biermacher et al. (2009) a búza esetében a helyspecifikus optikai érzékelővel megvalósult vizsgálatnak megfelelően, változtatható mennyiségben végzett nitrogénhatóanyag-kijuttatás gazdasági megvalósíthatóságát vizsgálva megállapította, hogy versenyképes a precíziós rendszer. Ugyanakkor nem minden esetben tökéletes, mert amennyiben elhagyták a vetés előtti ammóniatrágyázást, a precíziós technológia alkalmazásával nem lehetett felülmúlni az abból eredő költségelőnyt kizárólag a növény növekedési fázisában megvalósított ammónium-nitrát helyspecifikus kijuttatásával. Azaz amennyiben csakis fejtrágyázás során juttatták ki a szükséges nitrogénmennyiséget, még akkor is, ha azt helyspecifikus módon valósították meg, az nem vezetett jobb 
eredményre, mintha hagyományos technológiával alaptrágyáztak volna. Biermacher et al. (2009) megállapította, hogy a precíziós szenzoros érzékelés legfőbb előnye a nitrogénmütrágya költségének csökkenéséből adódik, ám mindemellett a hozamok növekedését is eredményezi a technológia. A mütrágyázásból származó nettó árbevétel több tényezőre is érzékeny. Egyrészt függ a búza- és a nitrogénforrás árától, másrészt a nitrogénhasználat hatásfokának szintjétől és a rendszer költségétől. A kimutatott, illetve tapasztalt költségcsökkenés hátterében az átfedések nélküli müvelés áll, amely során kizárható az egyes területekre duplán kijuttatott anyagmennyiség. A ráfedésmentes múvelés eredményeképpen Lencsés et al. (2014) szerint akár 30 százalékkal csökkennek az inputanyagok. Jacobsen et al. (2011) korábbi megállapításokra hivatkozva szintén jelentős inputanyagköltségmegtakarítást feltételezett a müvelés hatására. A vetőmag, a nitrogén-, foszfor- és kálium-hatóanyagú (NPK) mütrágyák, a gyomirtó, a gombaölő és a rovarölő szerek költségében egyaránt 3-5 százalékos megtakarítással számolt a dán gazdaságokban. Az üzemanyag-felhasználásban ennél jóval magasabb, 25-27 százalékos költségmegtakarítást is elképzelhetőnek tartott a gépnavigáció bevezetésének hatására. Az üzemanyagköltségben tapasztalt jelentős (25-27 százalékos) megtakarításnál kisebb arányú megtakarítás érhető el a növényvédelemben, viszont volumenben meghaladja azt. Bora et al. (2012) amerikai viszonylatban bebizonyította, hogy a GPS-alapú irányítási rendszernek köszönhetően az azt alkalmazó gazdaságok 6 százalékkal csökkentették az erőgép müködési idejét és 6,3 százalékkal kevesebb üzemanyagot használtak fel ezáltal. Azok a gazdaságok, amelyek automata kormányzást is alkalmaztak, tovább csökkentették a ráfordításaikat rendre 5,8 és 5,3 százalékkal. Jacobsen et al. (2011) a költségmegtakarítás mellett a precíziós gépnavigáció eredményeképpen a hozamokban 5-10 százalékos növekedéssel számolt. Feltételezte továbbá azt is, hogy amennyiben az összes elemet együttesen alkalmazzák az üzemek, a kijuttatott gyomirtó szer mennyisége jelentősen csökken, költsége akár 43-65 százalékkal is mérséklődhet az őszi búza, kukorica, repce és cukorrépa esetében egyaránt, emellett az egy hektárra jutó termésmennyiség 7-16 százalékkal is növekedhet a növénykultúrákban. Fontos kihangsúlyozni, hogy korábbi kutatások alapján Jacobsen et al. (2011) feltételezte a költségek ilyen mértékü csökkenését dán körülmények között.

A gyomszabályozásban Takácsné et al. (2009) gyakorlati tapasztalatokra alapozva megállapította, hogy a vetéssel egymenetben végzett, sorköz-kultivátorozással kiegészített sávpermetezés lényegesen csökkenti a vegyszerfelhasználás mértékét. A vegyszerfelhasználás mértéke akár az 50-60 százalékot is elérheti Sinka és Takács (2010) kutatása alapján. Takácsné et al. (2011) modellszámítással is igazolta a sorköz-kultivátorozással kiegészített sávpermetezés vegyszercsökkentő, ezáltal költséghatékonyság-növelö hatását a teljes felületen végzett kezeléshez képest. A kukorica és a napraforgó esetében táblaszintü üzemgazdasági elemzésekkel igazolta, hogy hektáronként akár 30-40 százalékkal csökkenthető a kijuttatott gyomirtó szer mennyisége. A hozamok tekintetében nem volt minden növénykultúra esetében egyértelmü a sávpermetezés előnye, mert a kukorica termesztése során a teljes felületkezeléssel magasabb hozamot tudtak elérni. Ennek ellenére a közel 50 százalékos költségmegtakarítás miatt mindkét növény esetében magasabb jövedelmet tudtak elérni a precíziós technológia alkalmazásával, így a kukorica és a napraforgó esetében is kimutatták a sávpermetezés gazdaságosságát. Takácsné (2010) szerint jelentős gyomirtószer-megtakarítást a széles sortávú növényeknél lehet elérni. A gyomirtásra vonatkozóan Kalmár (2010) a megelőző kutatási eredmények alapján a beruházás megtérülési számításaiban várhatóan 10-40 százalékos költségmegtakarítást feltételez a precíziós gazdálkodás hatására.

A precíziós szántóföldi növénytermesztés további előnye - a helyspecifikus vetés eredményeképpen - a vetőmag mennyiségének csökkenése. Sinka és Mesterházi (2014) 4 százalékos megtakarítást tapasztalt a vetőmagmennyiségben nagyüzemi gyakorlatban.

Az inputanyag-csökkentésből eredő megtakarítás következtében megállapítható, hogy az inputanyag-igényes növénykultúráknál (kukorica, napraforgó, szója) jelentkezik a nagyobb megtakarítás a magasabb hektáronkénti vegyszerköltség okán, így az alacsonyabb megtakarítási százalékok is 
fedezik a többletráfordítást, azaz ezen növények esetében gazdaságos a precíziós növénytermesztés alkalmazása (Takácsné, 2011; Kalmár, 2010). A fő szántóföldi növények közül a cukorrépa igényli a legtöbb növényvédő szert és a felhasznált üzemanyag-mennyiség is ennél a növénykultúránál a legnagyobb, ezáltal a költségmegtakarítás mértéke a cukorrépa esetében a legjelentősebb (Jacobsen et al., 2011).

A precíziós technológia a talajmüvelésben is eredményesen alkalmazható. A talajszerkezet állapotának fenntartása rendkívül fontos, mert a kijuttatott növényvédő szerek egy része a talajfelszínre jutva környezetszennyező elemként viselkedik, és amelyek lebomlása a talajszerkezet kedvező vagy kedvezőtlen állapotának függvénye. A nem megfelelően megválasztott talajmüvelési eszköz talajtömörödést okozhat, ezáltal szükségszerü azok körültekintő kiválasztása (Soane és Van Ouwerkerk, 1998). Sulyok (2005) különböző talajmüvelési rendszereket vizsgált agronómiai és ökonómiai szempontból. Megállapította, hogy minden olyan agrotechnológiai mód alkalmazásával, amellyel kialakítható és megőrizhető az adott kultúrnövény számára az optimális környezet - az évjárathatást is figyelembe véve -, a kedvezőtlen körülmény melletti alacsonyabb hozamhoz képest nagyobb hozam érhető el.

A különböző talajművelési technikák gazdaságosságát viszont rendkívüli mértékben befolyásolja a talajtípus és a csapadékmennyiség, ezért az eltérő müvelések hatásvizsgálata során figyelembe kell venni ezeket a tényezőket. A csernozjom talajon szántásos alapművelésnél a konvencionális mủveléssel szemben a precíziós technológiával 16 százalékkal, réti talajon pedig 8 százalékkal magasabb költségarányos jövedelmezőséget mutatott ki a kukoricatermesztésben Sulyok (2012). A hagyományostól eltérő beavatkozás a csernozjom talaj esetében 10 százalékkal csökkentette az önköltséget és hasonló mértékben a termelési költséget, miközben a jövedelem 20 százalékkal nőtt. Réti talajnál 4 százalékkal csökkent az önköltség és a termelési költség, a jövedelem pedig 9,2 százalékkal nőtt. Sulyok (2012) a precíziós gazdálkodás mellett a talajkímélő sávos művelés hatását is vizsgálta, amely során arra a megállapításra jutott, hogy csernozjom talajon a nedvességmegőrző müveléssel az aszályos években érhető el a precíziós szántásos technológiához képest kedvezőbb eredmény. Átlagos csapadékmennyiség vagy csapadékban bővelkedő években viszont a precíziós gazdálkodással magasabb jövedelem realizálható. A hagyományos őszi szántásnál viszont a sávos müvelés a réti talajon még csapadékos évben is gazdaságosabb.

A környezetre gyakorolt externális (külső gazdasági) hatások vizsgálata sem elhanyagolható a technológia előnyeinek meghatározásakor. A precíziós növénytermesztés környezeti és társadalmi fenntarthatósághoz való hozzájárulása nehezen számszerüsíthető, és sokan alábecsülik azt (EIP-AGRI, 2015), ennek ellenére a gazdasági elönyök mellett a környezetre gyakorolt hatásokat is rendkívül fontos szemléltetni. A kemikáliahasználatból származó környezetterhelés csökkenését többen kimutatták üzemi (Takácsné et al., 2011; Sinka és Mesterházi, 2014) és makroszinten (Takácsné, 2010) egyaránt. A herbicidmennyiség csökkenése révén a környezet vegyszerterhelése csökken és a talajban, illetve a növénykultúrában mérséklődnek a szermaradványok (Takácsné et al., 2011). Pozitív külső gazdasági hatásként említik továbbá a felszín alatti vizek nitrátterhelésének csökkentését (Sinka és Mesterházi, 2014). Schieffer és Dillon (2014) a precíziós technológia üzemgazdaságra és a természeti környezetre gyakorolt hatásait együttesen vizsgálta. A gazdasági hatások kimutatásához a nettó jövedelem mutatót használták. Agronómiai szempontból a hozamokra gyakorolt változást elemezték, míg a környezeti hatásvizsgálat során két indikátort vettek figyelembe, a nitrogénhasználatot és a szén-dioxid-kibocsátást. A befogadó vizek nitrogénterhelésével mérték a tápanyag-utánpótlással kijuttatott nitrogén-környezet-szennyezés mértékét. A hagyományos és a precíziós technológia összehasonlítása különböző környezetvédelmi szabályozási rendszerekre (adóztatás, kvótarendszer) és precíziós technológiai elemre is kiterjedt. Szabályozásmentes környezetben a precíziós növénytermesztés elterjedése növeli a nitrogénhasználatot és a szén-dioxid-kibocsátást. Ez az úgynevezett „visszapattanó hatás”, amely abból fakad, 
hogy az inputanyag-felhasználás hatékonyságát nem feltétlenül azok csökkentése eredményezi, adódhat azáltal is, hogy a nagyobb anyagmennyiség felhasználásának költsége alacsonyabb, mint az abból származó előnyök. Az automata kormányzásnál és a változó mennyiségü kijuttatásnál (Variable Rate Application, VRA) tapasztalt nitrogén- és szén-dioxid-mennyiségbeli növekedés is a visszapattanó hatásra reflektál. A VRA-technológiától azt várnánk, hogy csökkentse a kijuttatott mennyiséget, viszont a fentiekben leírt elv érvényesül ennél a technológiai elemnél is, azaz a hozamok növelése és ezáltal magasabb jövedelem elérése érdekében az üzemek növelik inputanyag-ráfordításukat. Az automata szakaszvezérlés sem csökkentette a nitrogénmennyiséget, ellenben a szén-dioxid-kibocsátás redukálódott a kevesebb növényvédő és rovarölő szer, illetve a permetezőgép csökkenő üzemanyag-felhasználásának köszönhetően. Habár a technológiák között akadt olyan, ami a nitrogén környezetterhelését nem csökkenti egyértelmüen, az összes precíziós elem együttes alkalmazása során a nitrogénmennyiség 1,1 százalékkal, a szén-dioxid-kibocsátás 3,4 százalékkal csökkent.

Összességében elmondható, hogy a precíziós gazdálkodás környezeti hatása függ az alkalmazott technológiától, illetve azok kombinációjától (Schieffer és Dillon, 2014). A precíziós gazdálkodás minél magasabb szintủ mủvelése egyértelmủen pozitív környezeti hatást eredményez, azaz a technológiai elemek együttes alkalmazása a fenntartható fejlődéshez nagymértékben hozzájárul.

A precíziós gazdálkodás előnyei és az alkalmazásból származó megtakarítások mellett a szakirodalmak többsége a technológia hátrányairól is említést tesz.

A legföbb hátránynak a szakirodalom egybehangzóan a beruházáshoz szükséges többletköltséget nevezi meg. A magas beruházási költségből adódóan a gazdálkodók nem merik vállalni a technológiai váltással járó esetleges kockázatot, amelynek minimalizálása a többletberuházás megtérülésének biztosításával lenne megoldható. A rizikó az input- és outputanyagok eltérö árában, az egymáshoz viszonyított változásában, a termelési szerkezetben (növénykultúrák és azok aránya), a precíziós gazdálkodás célkitüzésében (heterogén vagy homogén hozamok) és az üzemméretben rejlik (TakácsGyörgy és Takács, 2011). A technológia bevezetésének kockázata függ továbbá a táblán belüli heterogenitástól, a tápanyag-ellátottságtól és a gyomborítottságtól, illetve a termelési értéktől. Minél homogénebb a gyomborítottság és minél kiegyenlítettebbek a talajtulajdonságok, annál nagyobb lesz a megtérülés kockázata, hiszen a többletberuházást az anyagköltség-megtakarítás nem fedezi. A precíziós növényvédelemre való átállás kockázata alacsony gyomborítottságú terület esetén rendkívül magas, viszont minél nagyobb a gyomborítottsági szint, annál kedvezőbb a technológiára való áttérés addig a pontig, amíg az el nem éri a teljes felületkezelés szükségességét. A tápanyag-utánpótlás esetén a kijuttatott tápanyagmennyiség növelésével, azaz a termelésintenzitás emelésének hatására csökken a bevezetés kockázata (Takácsné, 2011).

További hátrány, hogy mélyreható, komplex ismeretanyaggal kell rendelkeznie a vezetőnek a megfelelő alkalmazáshoz (Kalmár, 2010; Takács-György és Takács, 2011), és a munkavállalói oldalról szintén szükséges a technológia ismerete, amelyet még sokan fenntartásokkal kezelnek. Ahhoz, hogy a precíziós eszközök adta lehetőségeket a gazdálkodók és az alkalmazottak teljes mértékben ki tudják használni, megfelelő szaktudásra van szükség. Az agrárszakemberek többsége jelenleg még nem rendelkezik kellő informatikai ismerettel. Fontos, hogy jól müködjön a kommunikáció a felhasználók és az agrárinformatikus szakemberek között, ehhez pedig szükség van megfelelö képzésre. Az oktatásokon való részvétel, az információ megszerzése különböző forrásokból elengedhetetlen (Sinka és Mesterházi, 2014) mind a gépkezelés, mind a teljes körü adatgyüjtési és elemzési folyamatok ismerete terén. A gyártók közül többen is felismerték az igényt, és az eladott gép mellé szolgáltatásként gépkezelői oktatást is nyújtanak, telefonon segítséget adnak, biztosítják a folyamatosan újuló szoftverekhez való hozzájutást. Mindazonáltal a termelők képzése mellett a szaktanácsadók számát is tovább kell növelni (KITE, 2016c). 
Lencsés (2013) felmérése alapján megállapította, hogy a precíziós növénytermelést alkalmazók a munkaerö- és munkaidö-szükséglet növekedését tartják a legjelentősebb gyakorlati hátránynak. Egy menetben nem lehet kijuttatni az eltérő hatóanyagú mütrágyákat, így minden összetevő esetében külön kell a táblára rámenni, amely növeli az üzemanyag-felhasználást, illetve több munkaórát és talajtömörödést eredményezhet (Sinka és Mesterházi, 2014). Azonban vannak olyan osztott tartályos önjáró gépek, amelyek képesek differenciáltan egy menetben kijuttatni a különböző hatóanyagú monomütrágyákat, ezáltal a talajtömörödés, a megnövekedett üzemanyag-mennyiség és munkaerö-felhasználás már kiküszöbölhető. Kalmár (2010) a hátrányok között megemlíti, hogy a precíziós technológia alkalmazásának hatékonyságát befolyásolja a tábla (valamint a gazdaság) mérete, továbbá a tábla heterogenitása (pl. talaj fizikai és kémia változékonysága a táblán belül).

A precíziós technológia terén problémát jelenthet az egymással nem kompatibilis rendszerek és eszközök használata. Emiatt egy precíziós beruházás akár elköteleződést is jelenthet egy-egy nagy nemzetközi gépgyártó mellett, különösen, hogy ma Magyarországon a gazdálkodók föként integrátorokon keresztül jutnak e technológiához, akik pedig erősen kötődnek egy-egy nagy gépgyártóhoz (IVSZ, 2016b).

\subsection{A precíziós gazdálkodás bevezetéséhez szükséges többletberuházás megtérülésének vizsgálata és az életképes fedezeti méret}

A precíziós szántóföldi növénytermesztés elterjedése szempontjából segítséget nyújtana az életképes üzemméret meghatározása, amelyet számos kutatás során eltérő nagyságban állapítottak meg magyarországi viszonyok között (Kalmár, 2010; Takácsné, 2011; Smuk et al., 2009; Ferencsik, 2015).

A fedezeti méret meghatározásához a technológiával elérhető jövedelemtöbblet megadása szükséges, amely az egyes technológiai elemek tekintetében nehezen számszerüsíthető. Minél bonyolultabb a precíziós gazdasági elem, annál nagyobb a beruházás összege és a megtérülési idő (Kalmár, 2010). Az üzemben keletkező jövedelmeket a fedezeti hozzájárulás és a nettó jövedelem alapján kalkulálva állapította meg Takács-György (2007) a technológia bevezetéséből adódó termelési szerkezetváltozás jövedelmezőségre gyakorolt hatását és ennek következményeképpen a precíziós gazdálkodás bevezetéséhez szükséges többletberuházás megtérülését. Az anyagköltségben együttesen (növényvédöszer- és mütrágyaköltség) maximálisan 10 százalékot, a müvelési többletköltségben 5 százalékot és a hozamokban 10 százalékos többletet feltételezett a modellszámításhoz. A beruházáshoz szükséges költségeket alapanyag-forgalmazók adatai alapján határozta meg. Mindezek eredményeképpen megállapította, hogy 206 hektáros üzemméretnél érte el a gazdaság a konvencionális üzemek jövedelemszintjét, azaz a közepes méretủ gazdaságokban lehet életképes a technológia alkalmazása. A kisméretű gazdaságok számára is létezik megoldás, hiszen a precíziós növénytermesztéshez nem szükséges feltétlenül beruházás, ugyanis bérszolgáltatásként is igénybe lehet venni a technológia egyes elemeit. A bérszolgáltatás, illetve a gépköri együttmüködés a technológiát birtokló gazdaságok számára is pozitív, a fajlagos költségeket csökkentheti, ezáltal a beruházás megtérülését gyorsíthatja (Takácsné, 2011). Mivel a magyar gazdálkodók körében az együttműködési hajlandóság és a bizalom a fiatalabb korosztályra jellemző, az agrárgeneráció-váltás pozitív hatást gyakorol az együttmüködések kialakítására, ezáltal a bérszolgáltatás igénybevételére, amely kedvező a technológia adaptálása szempontjából (Takács és Baranyai, 2010).

Smuk et al. (2009) szerint a gazdálkodás mérete és a tervezett hasznos élettartam szoros összefüggésben áll a technológia bevezetéséhez szükséges beruházások megtérülésével. Standard körülmények között két eltérő beruházásigényü rendszert vizsgáltak, mely során mindkét esetben feltételezték, hogy a gazdálkodáshoz nélkülözhetetlen gépekkel már rendelkezik az üzem, így a helyspecifikus 
tápanyag-visszapótláshoz elengedhetetlen eszközök beszerzéséhez szükséges beruházási összeggel számoltak, amely az első alternatívában 4587180 forintot, míg utóbbi esetében 3247400 forintot tett ki. Az első lehetőségnél a gazdaságos üzemméret 46 hektár, a második esetben 33 hektár, amenynyiben a megtérülési idő 6 év. Abban az esetben, ha a megtérülés idejét 1 évvel rövidítették, a fedezeti méret mindkét esetben közel 2,5-szeresére nőtt. A megtérülési idő érzékenyen reagál továbbá az árfolyamváltozásokra és a hozamingadozásra. Az árfolyam-ingadozások a modellszámításukban meghatározott változatokban 304 százalékos eltérést is eredményeztek, vagyis a kisebb gazdaságok számára akár veszteséges is lehet a beruházás az árfolyam kedvezőtlen alakulásának következtében. A hozamok változása szintén jelentősen módosítja az üzemméretet, hiszen 5 százalékos hozamcsökkenés mellett - 5 éves megtérülési időszak esetén - 14,5 százalékkal nő a gazdaságos üzemméret. A hozamok pozitív irányba történő elmozdulásakor viszont kevésbé intenzív a befolyásoló hatás. Takácsné (2011) megállapítása alapján a növényvédőszer-használat intenzitása is rendkívüli mértékben befolyásolja a megtérülési időt. Amennyiben csökkentik azt, a kritikus hozamszint és ezzel összefüggésben a kritikus üzemméret is kitolódik. A növényvédelemben a költség és az értékesítési ár változása módosítja a kritikus hozamnagyságot, az őszibúza-ágazatban például főként az árváltozás hatása dominál a hozamszint kitolódásában.

Ferencsik (2015) a szántásos, a középmély lazításos és a sávos talajművelési technológiákhoz szükséges beruházás megtérülését vizsgálta 50, 100, 150, 200, 250 és 300 hektáros müvelt területnagyság esetén. Megállapította, hogy csökkentett menetszámú szántásos és a középmély lazítóra alapozott, illetve a sávos technológia esetében egyaránt 150 hektár müvelt területnagyság szükséges ahhoz, hogy a beruházás megtérüljön.

\subsection{A szántóföldi növénytermesztésben alkalmazott precíziós technológia makrogazdasági hatásai}

A gyakorlati tapasztalat és egyes szakirodalmak (Schieffer és Dillon, 2015) megállapítása alapján az inputanyag-ráfordítás nem minden gazdaság esetében fog egyértelmüen csökkenni, hiszen azok az üzemek, amelyek a precíziós növénytermesztésre való áttérést megelőzően a szükségesnél kevesebb inputanyagot juttattak ki a termőterületükre, növelni fogják a növénytermesztés gyakorlatában nélkülözhetetlen anyagok mennyiségét a magasabb hozamok reményében. Ezáltal a precíziós gazdálkodás makroszintü hatásainak kimutatásakor nem számolhatunk minden körülmények között mennyiségi csökkenéssel, viszont hatékonyságnövekedéssel annál inkább. A fentiekben már említésre került, hogy a precíziós gazdálkodásból eredő költségmegtakarítást számos tényező befolyásolja, így a számszerüsítése különböző növénykultúrákra, eltérő talajadottságokra (heterogenitásra, gyomborítottságra, domborzati viszonyokra stb.) javasolt. Ennek eredményeképpen nehéz országos szinten a precíziós növénytermesztés hatásáról számot adni, viszont a már meglévő kutatási eredmények lehetőséget adnak közelítő becslésekre, amelyekből meg lehet állapítani a technológia széles körü elterjedtségéből eredő főbb hatásokat.

Takácsné (2011) megállapítása szerint a precíziós gazdálkodás bevezetésével 5-10-20 százalék közötti megtakarítás várható. Az üzemek 15, 25 és 40 százalékának áttérését feltételezve végzett számításokat szántóföldi növényt termelö és vegyes gazdaságok esetében. Az EU25-ök szintjén 15 százalék átálló üzem mellett a korábbi hozam eléréséhez 5 százalék megtakarítást feltételezve 32 ezer tonnával kevesebb hatóanyag kijuttatása szükséges, 20 százalék esetében ez 127 ezer tonna. Az üzemek 25 százalékos átállásával a megtakarítható mennyiség 53-211 ezer tonna, 40 százalékos átállás mellett pedig 85-338 ezer tonna. Magyarország tekintetében a korábbi hozamok elérése érdekében az üzemek 15 százalékos átállása mellett 964-3780 tonna hatóanyag megtakarítása tervezhető. Ugyanez 25 százalékos átállásnál 2027-8109 tonna, 40 százalékos átállásnál pedig 2521-10 082 tonna. Mindez jelentős költségmegtakarítást jelent, mivel a gabonafélék termelési költségeinek 8-15 százalékát teszi ki a tápanyagellátás anyagköltsége. A precíziós növénytermesztés széles körü elterjedése a mütrá- 
gyaköltségekben az EU25-ök szintjén 327-1308 millió euró megtakarítást eredményezhet, Magyarországon pedig 8,5-34,3 millió eurót.

A növényvédöszer-felhasználás csökkentése révén jelentősebb, 25-30-50 százalékos anyagmegtakarítás érhető el a precíziós gazdálkodásra való áttéréssel. Az EU25-ök esetében az üzemek 15 százalékának átállása mellett 5,7-11,4 ezer tonnával kevesebb hatóanyag kijuttatása tervezhető, míg 25 százalékos átállásnál 8,2-14,1 ezer tonna, 40 százalékos átállásnál pedig akár 15,2-30,4 ezer tonna is lehet a megtakarítás. Magyarországon ágazati szinten, amennyiben az üzemek 15 százaléka tér át precíziós gazdálkodásra, 137-275 ezer tonna növényvédő szer takarítható meg, az üzemek 25 százalékos átállásánál 229-587 ezer tonna, 40 százalékos átállást feltételezve pedig akár 470-940 ezer tonna. Ez az EU25 szintjén 1674-2648 millió euró, Magyarország vonatkozásában 46,6-93,2 millió euró költségmegtakarítást jelent éves szinten.

Jacobsen et al. (2011) a gépnavigáció és a precíziós technológia elterjedésének a dán makrogazdaságra gyakorolt hatásvizsgálata során megállapította, hogy a teljes technológia országos szintü alkalmazásának hatására a gazdák jövedelmi helyzete erősödne, az üzemanyag-felhasználás és a növényvédő és gyomirtó szer mennyisége pedig csökkenne, ennek következtében a biológiai sokféleség (biodiverzitás) javulna. Az agrárgazdaság jövedelme, illetve a mezőgazdaság és az élelmiszeripar termelése egyaránt növekedne, ha minél nagyobb számban térnének át a gazdálkodók a precíziós növénytermesztésre. Az agráriumban megtermelt mennyiség növekedésének hatására más iparágak relatív versenyképessége romlana, aminek köszönhetően azok tovább növelnék produktivitásukat. Abban az esetben, ha minden gazdaság precíziós technológiával végezné termelését, a bruttó kiadások értéke 24,8 millió euróval (0,013 százalékkal), a bruttó hazai össztermék (GDP) pedig 26,4 millió euróval, azaz 0,012 százalékkal növekedne. Összességében a precíziós gazdálkodás minél szélesebb körben való elterjedése hasznos lenne a dán gazdaság számára.

A makrogazdasági tényezők kapcsán fontos említést tenni a precíziós technológia agrár-környezetvédelmi szabályozásra gyakorolt hatásáról is. Schieffer és Dillon (2014) amerikai kutatók megállapították, hogy habár a precíziós növénytermesztés növeli az inputanyag-felhasználás hatékonyságát, a szabályozásra egyes esetekben ellenkező hatást fejt ki, különösképpen a gazdasági ösztönzőkön (adók, támogatások) alapuló szabályozás hatásosságát csökkenti. Ahogy az a fentiekben már említésre került, a precíziós technológia alkalmazása attól függően, hogy milyen technológiai elemet használnak a gazdálkodók (automata kormányzás, automata szakaszvezérlés, VRA-technológia, illetve ezek kombinációja), eltérő hatást gyakorol a környezetre. Annak ellenére, hogy egyes technológiai elemek szabályozásmentes környezetben történő alkalmazása nem módosítja, esetlegesen növeli a felhasznált nitrogén mennyiségét és ezáltal a környezetre negatív hatású, az elemek teljes vertikumának együttes használata egyaránt csökkenti a nitrogénfelhasználást és a szénlábnyomot. A technológiák kombinációjával a nitrogénlimit betartásához a gazdálkodónak kevésbé kell csökkentenie annak mennyiségét, az adóztatás hatására pedig a termelők több nitrogént használnak fel, mintha nem lenne érvényben környezetvédelmi szabályozás, vagyis mindkét szabályozási mód esetében csökken annak hatékonysága a precíziós gazdálkodásra való áttérés hatására. A hatékonyságveszteség okára a környezetszennyezés gazdaságtana ad magyarázatot, miszerint a felhasznált nitrogénmennyiség csökkenéséből adódóan a szennyezés mérséklődik, ezáltal az egységnyi szenynyezés megszüntetésére jutó költség (szennyezéselhárítási határköltség) - amely elmaradt haszon formájában jelentkezik - pedig növekedni fog. Mindez a termelők hozzáállásának megváltozását vonja maga után a környezetszennyezés mérséklésére vonatkozóan. Így a hagyományos termelési szerkezetü üzemekre kialakított szabályozási rendszer a precíziós gazdaságokra már nem alkalmazható eredményesen. Ez a felismerés az agrárgazdaság szennyezőanyag-kibocsátása szabályozásának megalkotásában érdekelt szakembereket arra készteti, hogy számításba vegyék a precíziós technológia egyre nagyobb terjedését, illetve annak hatásait, és módosítsanak a meglévő környezetvédelmi szabályozáson. 



\section{Anyag és módszer}

Kutatásunk során kétféle primer információs forrásra támaszkodtunk. Egyfelől a precíziós mezőgazdaság és talajkímélő müvelés magyarországi elterjedtségének, illetve alkalmazási jellemzőinek feltárása céljából kérdőíves felmérést végeztünk. Ezen felül néhány (szám szerint három) mintaüzemben - amelyek ugyancsak kitöltötték a kérdöívünket - mélyinterjúkat végeztünk. A kérdöíves primer adatgyüjtést azután szekunder adatokkal is összekapcsoltuk, és az így kapott adatbázison végeztük el a technológiai előnyök, illetve hátrányok vizsgálatát. A mélyinterjúba bevont mintaüzemekre vonatkozóan is rendelkeztünk pénzügyi adatokkal, amelyeket ugyancsak elemeztünk. Jelen fejezet első részében a kérdőíves felmérés jellemzőit, valamint az ehhez szorosan kapcsolódó statisztikai jellegü vizsgálatokat ismertetjük, a második részben pedig a mélyinterjúkba bevont mintaüzemek adatain végzett vizsgálatokat mutatjuk be.

\subsection{Kérdőíves felméréshez és az ökonómiai vizsgálatokhoz kapcsolódó módszertani megjegyzések}

A kérdőíves felmérés a precíziós és a talajkímélő gazdálkodás szántóföldi növénytermesztésben való elterjedtségére és alkalmazásuk körülményeire terjedt ki, és amely az AKI tesztüzemi rendszerben szereplő közel 1000 szántóföldi növénytermesztő üzem körében valósult meg. A kérdőívre 656 üzem adott választ, azaz az AKI tesztüzemi rendszerben nyilvántartott szántóföldi növénytermesztő üzemek megközelítőleg 70 százaléka. A mezőgazdaságban közel 110 ezer egyéni gazdaság és társas vállalkozás müködött 2015-ben, melyből a válaszadók az egyéni gazdaságok 61,5 százalékát, míg a társas vállalkozások 65,6 százalékát reprezentálják. A kitöltők közül 45 bizonyult precíziós növénytermesztőnek, azaz a 656 válaszadó 6,9 százaléka végzett precíziós tevékenységet a 2014/2015-ös termelési évben, akik az egyéni gazdaságok 1,2 százalékát, míg a társas vállalkozások 4,5 százalékát reprezentálják.

A kutatás során a precíziós növénytermesztés statisztikailag igazolható közgazdasági hasznának kimutatása volt a cél. Választ kerestünk arra, hogy a magyarországi termelöknek megéri-e a precíziós technológiát alkalmazni, hiszen ahogy az a fentiekben már említésre került, a szakirodalom eltéröen vélekedik a precíziós növénytermesztés jövedelmezőségéről. Itt kell megjegyeznünk, hogy bár a precíziós technológia előnyeinek kimutatása volt a fó cél, ugyanakkor a precíziós és talajkímélő mủvelés hatásai sem a hozamok, sem pedig a költségek tekintetében nem választhatók szét a gyakorlatban, ezért azok hatása együttesen kerül figyelembevételre. A fogalmazás egyszerüsítése céljából a továbbiakban a precíziós technológia hatásait tárgyaljuk, azonban minden esetben feltételezzük a talajkímélő gazdálkodás adottságokhoz illeszkedő alkalmazását.

A precíziós gazdaságok által a kérdőívre adott válaszok összekapcsolhatók voltak a tesztüzemi rendszer adataival, illetve az ágazati költség- és jövedelemelszámolási adatokkal, hiszen a tesztüzemi rendszerben szereplő vállalkozások töltötték ki azt. Az adatok összefésülése mélyebb elemzéseket tett lehetővé. Az összekapcsolás során a hibás válaszokra is fény derült, így azokat kiszürtük a vizsgálatból. A mintasokaságot képező 656 üzem közül azok a gazdaságok kerültek besorolásra a precíziós növénytermesztők közé, amelyeknél egyértelmüvé vált, hogy a technológia alkalmazására adott válasza igaz, azaz minden további a helyspecifikus gazdálkodását érintő kérdésre is értékelhető választ adott. A gazdálkodók válaszai először a tesztüzemi rendszer üzemi szintủ adataival kerültek összevetésre, azaz minden üzemhez a 2015. évi mérleg- és eredménykimutatás-adata kapcsolódott. A kérdőívre érkezett válaszok üzemi szintü adatokkal való összekapcsolása nem volt célravezetö, ugyanis a mélyinterjúk során is megerősítés érkezett arra vonatkozóan, hogy számos eredménykimutatásban szereplő tétel torzítja a precíziós gazdálkodásból származó jövedelem megállapítását. Mivel kizárólag a helyspecifikus szántóföldi növénytermesztésből eredő haszon kimutatása volt a cél, így a támogatások és a földbérleti díj torzító hatásával volt szükséges korrigálni az 
adatokat. Emellett viszont számos egyéb a precíziós tevékenységhez közvetlenül nem köthető tétel is jelentősen befolyásolta mind az árbevétel, mind a költségek oldaláról a vállalkozások eredményeit (például az integrátori szerepet betöltő gazdaságoknál az ebből a tevékenységből származó árbevétel alakulása). Az adatok ilyen tényezőktől való konzisztens megtisztítása információk hiányában nem volt lehetséges mind a 45 gazdaságnál, így a gazdaságok üzemi szintű adatai helyett a precíziósan termesztett növénykultúráik költség- és jövedelemadatait kapcsoltuk össze a kérdöívben megjelölt válaszokkal. Ez azt jelenti, hogy a számítások az AKI Ágazati Költség- és Jövedeleminformációs Osztálya által összeállított ágazati adatbázisból származó információkon alapulnak. A számítások alapját a több év adatait felhasználó esetekben vetésterülettel súlyozott és minden esetben hektárra vetített adatok képezték.

Az összehasonlítás alapját kontrollcsoportok kialakításával biztosítottuk. Az eltérő szempontok figyelembevétele a precíziós szántóföldi növénytermesztés jövedelmezőségének elemzése során négy különálló, ám egymással összefüggő számítási változatot eredményezett.

Az első változatnál megállapításra került, hogy mely növénykultúráknál folytatott precíziós termesztést a gazdaság a 2014/2015. gazdálkodási évben és ezen növényekre külön lett meghatározva a kontrollcsoport az ágazati adatbázisban szereplö összes hagyományos szántóföldi növénytermesztést végző üzem figyelembevételével. A kontrollcsoportot képező üzemek egy hektárra vetített átlagos adatai kerültek összehasonlításra a helyspecifikusan gazdálkodó üzem értékével, majd a két érték százalékos eltérésének átlaga fejezi ki a hagyományos és a precíziós gazdálkodás különbségét. A kontrollcsoport kialakításánál megkülönböztettük az egyéni gazdaságokat és társas vállalkozásokat, azaz ha a precíziós gazdálkodást egyéni gazdaság folytatta, akkor a kontrollcsoportba is kizárólag egyéni gazdaságokat vettünk figyelembe. A végső átlagos százalékos eltérés egyéni és társas gazdaságokat egyaránt magában foglal.

A vizsgálat tárgyát 13 kultúrnövény és 45 gazdaság képezte. Előbbiek közül a számítás a búzánál és a kukoricánál 32, napraforgónál 27, őszi káposztarepcénél 16, őszi árpánál pedig 13 precíziós gazdaságra terjedt ki. A fennmaradó növénykultúráknál (szójabab 5, cukorrépa 4, tavaszi árpa 3, őszi durumbúza 3, csemegekukorica 2, őszi tritikálé 2, rozs 1, tavaszi zab 1 üzem) az alacsony mintaelemszám miatt nem lehetett elvégezni a vizsgálatokat.

Mivel a vizsgált 45 üzemből 17 esetében volt elérhető információ hosszabb időszakra, a második változatban indokolttá vált ezen gazdaságok részletes vizsgálata. A 17 üzemnél az új termesztéstechnológia bevezetése előtt legalább 3 évre, a precíziós technológia bevezetését követően pedig legalább 2 évre - bevezetés évével szintén három évre - vonatkozóan állt rendelkezésre ágazati költség- és jövedelemadat. Az időjárási hatások kiszürése céljából a 17 üzem 3 éves átlagadatai képezték a számítások alapját, amelyeknél figyelmen kívül hagytuk azokat az éveket, amikor elemi kár miatt szenvedett hozamkiesést a gazdaság. A kontrollcsoport képzése a fentiekhez hasonlóan alakult, az egyéni és társas gazdaságokra külön-külön. Minden gazdaság adott évi adatához a kontrollüzemek megegyező évi értékeinek társítása után átlagolásra kerültek az eredmények. Mivel egy-egy ágazatban évente nem szükségszerüen ugyanazok az üzemek szerepelnek, ezért az egyes évek kontrollcsoportjai kismértékben változnak. Ez alapján a vizsgálat tárgyát a búza esetében 12, kukoricánál 10, napraforgónál 8 üzem képezte. Öszi káposztarepcét 2, őszi árpát 3, csemegekukoricát és szójababot pedig mindössze 1 üzem termesztett a 17 közül.

A harmadik változatban a szakirodalomban leírtak és a mélyinterjún elhangzottak alapján a kontrollcsoportba eső üzemek körét intenzitásuk és területük alapján szükítettük. Mivel a precíziós szántóföldi növénytermesztés hagyományos termesztéstechnológiával való összehasonlítása során az extenzíven gazdálkodókat és az intenzíven termelőket külön szükséges kezelni, így a kontrollcsoportban is szét kellett választani őket. Ennek megfelelően a termelési költségekben maximum \pm 20 százalékos eltérés volt megengedhető a kontrollcsoportban a mintaüzemekhez képest. Továbbá 
a vetésterület mérete is jelentősen befolyásolhatja az eredményt, így abban szintén \pm 20 százalékos intervallum került meghatározásra. Az előző változathoz hasonlóan a 17 üzemnél a precíziós technológia bevezetésétől számított 3 év adatainak átlaga, míg a kontrollcsoport esetében szintén a mintaüzemeknél vizsgált évek kerültek elemzésre. Abban az esetben, amikor a \pm 20 százalékos feltétel szüknek bizonyult, azaz a precíziós üzemekhez tartozó kontrollcsoportba csak nagyon kevés (10-nél kevesebb) üzem tartozott, ott a korlátozó feltétel \pm 10 százalékkal - azaz \pm 30 százalékra - bővítésre került.

A negyedik változatban a területi, domborzati, üzemméretbeli stb. különbözőségek kiszürése céljából az üzemeket önmagukkal vetettük össze. Pontosabban azt vizsgáltuk, hogy a technológia bevezetése előtt és után hogyan változott a gazdaságok teljesítménye. A vizsgálat során a precíziós technológiára való áttérés eredménye, vagyis a bevezetés előtti időszak éveinek átlaga került összehasonlításra az alkalmazás utáni évek átlagos adataival a különbözö növénykultúrákban. Minden üzemnél a különböző növénykultúrákban alkalmazott technológiára vonatkozó költség- és jövedelemelszámolási tétel változását vizsgáltuk, vagyis amennyiben a termesztés során a tápanyagutánpótlásban differenciált kijuttatást alkalmaznak, úgy a felhasznált mütrágyamennyiség, illetve -költség képezte az elemzés tárgyát. Sajnálatos módon nem állt rendelkezésre minden inputanyagra vonatkozóan mennyiségi adat, ezáltal a növényvédő szer és a vetőmag alakulásának vizsgálata során kizárólag költségadatokra tudtunk támaszkodni. Ezen változóknál viszont az árszínvonal-változás hatását figyelembe kellett venni, így a növényvédőszer- és a vetőmagköltséget egyaránt defláltuk a Központi Statisztikai Hivatal által meghatározott ráfordítás-árindex adatai alapján. Ennek megfelelően az áringadozás mértékével korrigált adatok pontosabban szemléltetik a precíziós gazdaságok inputanyag-ráfordításainak alakulását. Továbbá a hozamátlagok megállapításánál figyelembe vettük az elemi kár miatti hozamkiesést, vagyis a vizsgált évek közül kiszürtük azokat, amikor a gazdaság az időjárás miatt szenvedett el hozamcsökkenést.

Valamennyi számítási változatnál felmerült, hogy különbséget kellene tenni a precíziós gazdaságok között aszerint, hogy milyen mélységben alkalmazzák a technológiai elemeket a különböző munkaműveleteknél. Ennek érdekében öt kategóriába soroltuk az üzemeket:

1. az egyes agrotechnikai folyamatokban kizárólag sorművelést végző - azaz sorvezetőt használó - üzemek;

2. a technológiát kombináltan, egy menetben több agrotechnikai elemben alkalmazók (például a talajmủvelésben alapmüveléssel egybekötött tápanyag-kijuttatást, a növényvédelemben kapcsolt differenciált fejtrágyázást végzők);

3. azok a gazdálkodók, akik az előzőeken túl a vetés során is képesek változtatni a tőszámot, illetve a talajmüvelés gyakorlatában pedig a müvelésmélységet;

4. a precíziós technológia csúcsán azok az üzemek kaptak helyet, amelyek menedzsmentzónákat alakítanak ki és differenciáltan juttatják ki a növényvédő szert és/vagy a műtrágyát a területeknek megfelelö mennyiségben;

5. a kérdőíves válaszadás során lehetőség volt az egyéb kategória megjelölésére az agrotechnikai elemekre vonatkozóan, ezáltal az egyéb választ adók köre képezte a technológiai bontásban szereplő utolsó csoportot.

A besorolás eredményei a 6 . mellékletben szerepelnek. Sajnos a mintaelemszám nem bizonyult elegendőnek ahhoz, hogy e kategorizálás figyelembe vehető legyen az egyes vizsgálatoknál.

A hipotézisek az SPSS program segítségével kerültek igazolásra, illetve elvetésre. A 17 precíziós üzem által termesztett növénykultúra, illetve a hozzájuk tartozó kontrollüzemek növényei esetében a hipotézisek igazolásához szükséges ismérvekre (hozam, egységnyi termelési költségre vetített termelési érték, önköltség, ágazati eredmény) különböző statisztikai mutatókat vizsgáltunk. A mutatók a következők: átlag, módusz, medián, szórás, szórás terjedelme, minimum- és maximumérték, emellett az interkvartilis terjedelem is lehatárolásra került. Ezt követően aszimmetria-, csúcsosság- és 
végül normalitásvizsgálat alá vetettük a főbb változókat. A normalitásvizsgálat során Shapiro-Wilkpróbával került meghatározásra a szignifikancia szintje, amely ha 0,05-nél nagyobbnak bizonyult, abban az esetben beigazolódott a normalitás. A normalitásvizsgálat eredménye lehetővé tette a varianciaelemzés elvégzését (ANOVA-teszt), amely során igazolásra kerültek az általunk megfogalmazott hipotézisek.

\subsection{A mintaüzemek vizsgálatához kapcsolódó módszertani megjegyzések}

A mintaüzemek vizsgálatánál az alábbi adatforrásokra támaszkodtunk:

- A precíziós és a talajkímélő gazdálkodás szántóföldi növénytermesztésben való elterjedtségére és alkalmazásuk körülményeire vonatkozó kérdőíves megkérdezés adatai.

- Az AKI Ágazati Költség- és Jövedeleminformációs Osztálya által gyüjtött és összeállított 2010-2015-ös időszakra vonatkozó ágazati adatbázisból származó információk.

- Az Agrárgazdasági Kutató Intézet Tesztüzemi Információs Rendszerének 2010-2015-ös idöszakra vonatkozó ágazati költség- és jövedelemadatai.

- A vizsgálat során a mintaüzemek adatait vetettük össze a nem precíziós gazdálkodást végző üzemekből képzett kontrollcsoporttal. Az ide tartozó üzemeknél - a kérdőívek alapján végzett vizsgálatokhoz hasonlóan - figyelembe vettük, hogy egyéni gazdaságként vagy társas vállalkozásként müködnek-e.

A két csoport közötti vizsgálat alapját 5 növénykultúra képezte: búza, kukorica, napraforgó, őszi káposztarepce és cukorrépa. Az ágazatok szerint differenciáltuk a fent említett két csoportot és a 2010-2015-ös időszakra vonatkozóan határoztuk meg az átlagos értékeket, amelyek vetítési alapja a vetésterület (hektár), illetve a megtermelt mennyiség (tonna) volt.

Az összehasonlíthatóság miatt a mintaüzemek eredményei alapján a kontrollcsoport üzemeinek körét szükítettük növénykultúránként, melynek alapja a mintaüzemek ágazatonkénti, azon belül évenkénti vetésterülete és termelési költsége volt. Mind a vetésterület nagysága, mind a termelési költségekben minimum \pm 30 százalékos eltérés volt megengedhető a kontrollcsoportban a mintaüzemekhez képest. A kontrollcsoportba tartozó üzemek esetében az eltéréseket a mintaüzemek adatai alapján évente határoztuk meg. Abban az esetben, amikor a feltételként meghatározott intervallum szúknek bizonyult - nem került üzem a kontrollcsoportba -, a korábban meghatározott értékköz néhány esetben bővítésre került.

\subsection{A makrobecslés és a beruházásmegtérülési vizsgálatok módszertana}

A 8.2 fejezetben becslést végeztünk arra vonatkozóan, hogy hogyan alakulnak a gazdálkodást jellemző mutatók ágazati szinten abban az esetben, ha az üzemek egy csoportja áttér a precíziós gazdálkodásra. Az áttérést azon üzemek esetében feltételeztük, amelyeknél az ökonómiai vizsgálatok azt jelezték, hogy a precíziós technológia a hagyományoshoz képest magasabb fajlagos jövedelemmel bír. A technológiaváltást végzö üzemek lehatárolásánál két tényezőt vettünk figyelembe, a méretet és a termelési költséget. Csak azoknál az üzemeknél feltételeztük a precíziós gazdálkodás bevezetését, amelyeknek területe elérte a vizsgált 17 precíziós üzem területének alsó határát. A méretküszöbök tekintetében differenciáltuk az üzemeket aszerint, hogy a tevékenységet egyéni vagy társas gazdálkodásban folytatja-e az üzem. A második korlátot a termelési költség jelentette; azokról az üzemekröl feltételeztük, hogy áttérnek a precíziós gazdálkodásra, amelyek termelési költsége meghaladta a 17 precíziós üzem ágazatonkénti legalacsonyabb fajlagos termelési költségét. Az egyéni és társas gazdaságok között ez esetben is különbséget tettünk. 
Fontos megjegyezni, hogy a területi korlátokat napraforgó és őszi káposztarepce esetében lefelé, az őszi árpa esetében felfelé korrigáltuk. Erre azért volt szükség, mert a becslés eredményeként ezen növények teljes vetésterületéhez képest aránytalanul magas vagy alacsony területnagyság adódott. Ez a gyakorlatban nem fordulhat elö, mivel az egyes gazdaságok vetésforgóban termelnek (ennek pedig gyakran mind az öt növény részét képezi), ezért elképzelhetetlen, hogy ilyen mértékü területi különbségek adódjanak. A becslés alapjául szolgáló mintában szereplő üzemek között kevés volt a precíziós, ezért a kontrollcsoportok behatárolása során napraforgónál és őszi káposztarepcénél a többi növényhez képest nagyon nagy, őszi árpánál pedig kisebb területek keletkeztek. A tény- és módosított adatokat a 10. mellékletben közöltük, az eredeti korláttól való eltérést szürke színnel jelöltük.

Az alábbiakban a precíziós gazdálkodás hozamra, termelési értékre, termelési költségre, ágazati eredményre, vetőmagköltségre, növényvédőszer- és mütrágyaköltségre gyakorolt hatásait bemutató ábrákon a százalékos értéket a fejezet első felében már részben közölt minimum- és maximum(szorzók) értékekkel számítottuk. (Az összes felhasznált szorzót a 11. melléklet tartalmazza.)

A beruházásmegtérülési vizsgálatnál nettó jelenérték-számítást végeztünk 7 éves időszakra 3 százalékos kamattal. A megtérülési vizsgálatokhoz kapcsolódó egyéb módszertani megjegyzéseket a 8.3. alfejezetben részletesen közöljük. 



\section{A precíziós és a talajkímélő gazdálkodás elterjedtsége, alkalmazásának színvonala és termelői megítélése}

A precíziós gazdálkodás és talajkímélő művelés hazai helyzetének felmérése céljából a szántóföldi növénytermesztéssel foglalkozó tesztüzemi gazdaságok körében primer adatgyüjtést végeztünk. A felmérés során arra a kérdésre kerestük a választ, hogy a termelők milyen forrásokból szereztek tudomást a precíziós és a talajkímélő gazdálkodásról, mely tényezők gátolták őket a korábbi bevezetésben, illetve hogy melyek azok az ösztönzők, amelyek elősegíthetnék a technológia elterjedését. A megkérdezés alkalmával kitértünk a precíziós gazdálkodási technológiák környezeti/gazdasági/ társadalmi fenntarthatósághoz való hozzájárulásának megítélésére, az agrotechnikai felszereltségre, a precíziósan végzett tevékenységre, a technológia üzemre gyakorolt hatására és a növénytermesztés gyakorlatában megvalósult változásra. A termesztett növénykultúrák precíziós gazdálkodással müvelt területére, illetve a növényfajokban alkalmazott technológiai elemekre a 2014/2015. gazdálkodási évre vonatkozóan adtak információt a termelők. Végül a felmérésben a talajkímélő művelési elemekre és azok hatására is rákérdeztünk.

A kérdőívet kitöltő 656 szántóföldi növénytermesztő gazdálkodó közül 45 vállalkozás alkalmazott precíziós technológiát a vizsgált termelési évben, míg 112 gazdaság úgy nyilatkozott, hogy talajkímélő mủvelést végez. A kérdőív első része a precíziós gazdálkodásra vonatkozó általános kérdéseket tartalmazta, így ezen szakaszban az összes értékelhető kitöltés került elemzésre. A második blokkra kizárólag a precíziós szántóföldi növénytermesztőktől vártunk választ, a harmadik egységben pedig a talajkímélö technológiát alkalmazók szolgáltattak adatot.

\section{1. Általános kérdések}

Szinte valamennyi válaszadó hallott a precíziós és a talajkímélő technológiáról. Előbbiről mindösszesen a kérdőív kitöltők 0,5 százaléka, míg utóbbiról 0,6 százaléka nem értesült a felmérést megelőzően (5. ábra). A kitöltők közel 60 százaléka szerint a precíziós gazdálkodás tekintetében a legjelentősebb kommunikációs csatornának a nyomtatott szakmai lap bizonyult, míg a talajkímélö mủvelésről elsősorban más gazdálkodótól hallottak. A válaszadók nagy része internetes szakmai oldalakon értesült a technológiákról, emellett kiállítások, vásárok, szakmai bemutatók keretében, illetve szaktanácsadótól is sokan szereztek tudomást és információt az általunk vizsgált gazdálkodási technológiáról. Kevésbé volt jellemző az alapanyag- vagy gépforgalmazóktól, a szakmaközi szervezetektől vagy az oktatás keretében szerzett ismeret.

A precíziós és a talajkímélő gazdálkodásról értesülők többsége elismeri a technológiák környezeti és gazdasági fenntarthatósághoz való hozzájárulását (6. ábra). A válaszadók 43,2 százaléka szerint számottevő mértékben, közel egyharmada szerint jelentősen és további mintegy 23 százaléka szerint pedig kismértékben járul hozzá a két gazdálkodási technológia a környezet állapotának megőrzéséhez, illetve javításához. A gazdasági fenntarthatósághoz való hozzájárulás mértékéröl hasonlóan vélekedtek a válaszadók, a társadalmi fenntarthatóságról viszont már nem képviselnek egységes álláspontot. A két növénytermesztési technológia a kitöltők 13,8 százaléka szerint semmilyen formában nem járul hozzá a társadalmi fenntarthatósághoz. 


\section{5. ábra: Technológiai ismeretek forrásai}

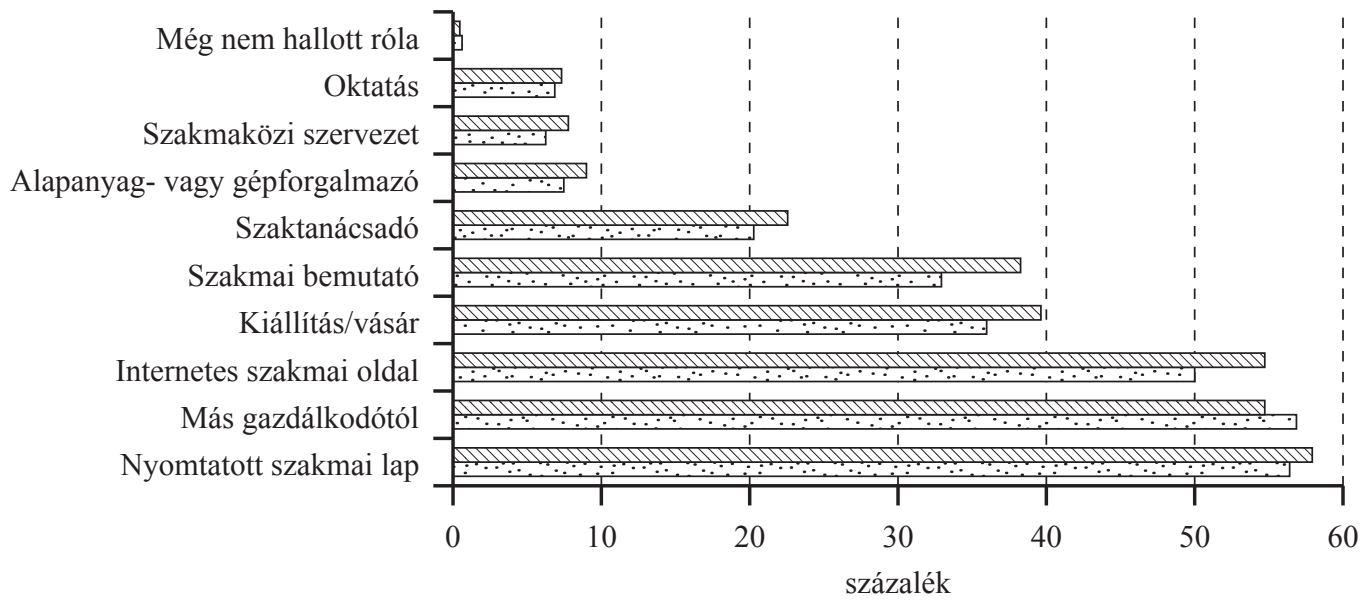

Precíziós gazdálkodás

Talajkímélő gazdálkodás

Forrás: Kérdőíves felmérés adatai alapján készült az AKI Horizontális Elemzési Osztályán

\section{6. ábra: A precíziós és a talajkímélő müvelés fenntarthatósághoz való hozzájárulása}

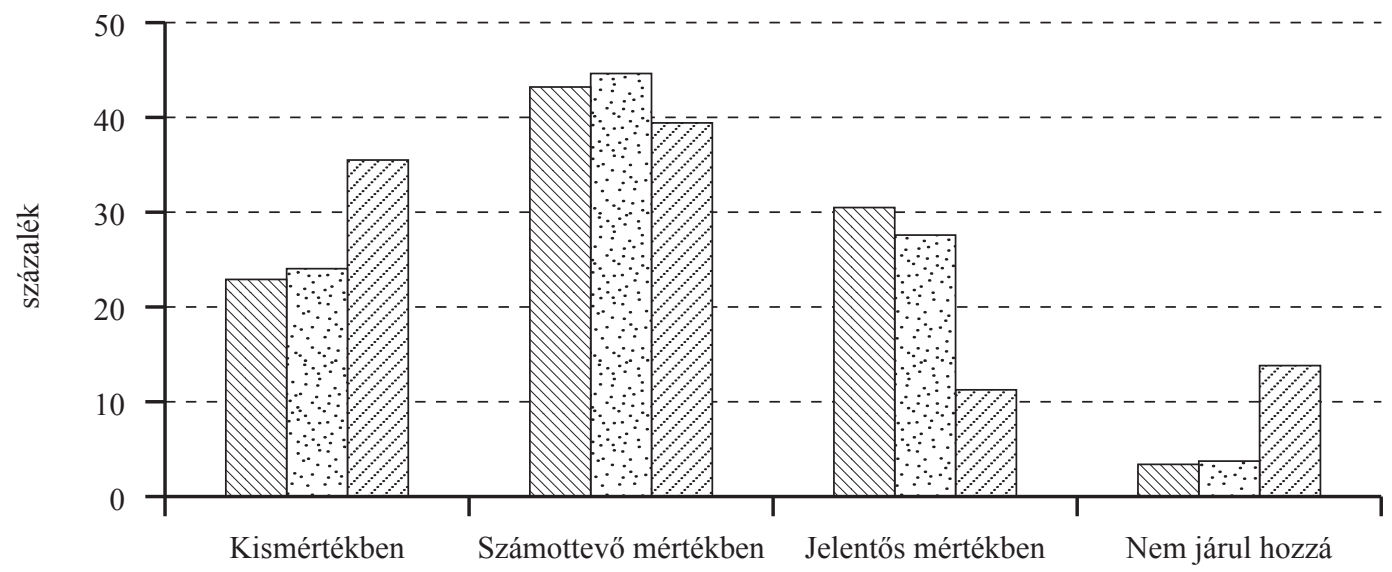

MV A környezeti fenntarthatósághoz való hozzájárulás mértéke

$\therefore$ A gazdasági fenntarthatósághoz való hozzájárulás mértéke

- A társadalmi fenntarthatósághoz való hozzájárulás mértéke

Forrás: Kérdőíves felmérés alapján készült az AKI Horizontális Elemzési Osztályán

Annak ellenére, hogy csaknem valamennyi gazdálkodó értesült a technológiákról és elismeri annak a fenntarthatósághoz való hozzájárulását, számos gátja van a müvelésmód terjedésének. A legfőbb akadályt mindkét esetben a válaszadók egyértelmüen a beruházás többletköltségében látják. A precíziós növénytermesztésre való áttérés esetében a magas beruházási költségre a 460 értékelhető kitöltés több mint fele, míg a talajkímélő müvelést végzőknél a kitöltések 31,8 százaléka hivatkozott. Ez azon hipotézisünket támogatja, miszerint a precíziós szántóföldi növénytermesztés elterjedését leginkább akadályozó tényező a magas beruházási költség. A precíziós gazdálkodás elterjedését gátló tényezőket azonosítók 15,0 százaléka szerint gazdasági méretükhöz nem alkalmazható eredményesen a technológia és további 12,0 százalékuk szerint a bevezetéséhez szükséges többletráfordításhoz 
nem áll rendelkezésre megfelelő finanszírozási lehetőség. A várakozásoknak megfelelően azok a gazdaságok, amelyek az üzemméretükhöz nem tudták elképzelni a precíziós technológia bevezetésének eredményességét, zömében (77,8 százalék) 200 hektár alatti vetésterülettel rendelkeztek. A finanszírozási lehetőség hiányát megnevezők között nem meglepő módon domináltak (a válaszadók 83,6 százaléka) a kisméretü, családi gazdaság tagjaként, egyéni vállalkozóként vagy őstermelőként tevékenykedő gazdaságok. A precíziós gazdálkodás elterjedésében a válaszadók szerint problémát jelent továbbá az alkalmazáshoz szükséges szaktudás és az üzemeltetési tapasztalat hiánya, illetve az új technológiával szembeni bizalmatlanság is gátat szab a terjedésnek (7. ábra). Kevésbé tartják akadályozó tényezőnek, hogy a hiányzó technológiai elemek nem vehetők igénybe szolgáltatásként és véleményük szerint az új technológia bevezetéséhez szükséges idő hossza sem gátolja jelentős mértékben a gazdálkodókat a bevezetésben. Az elérhető szaktanácsadás hiányát elenyésző számban jelölték meg a termelök az elterjedést gátló tényezők között, vélhetően azért, mert a válaszadók többsége még nem alkalmazta a technológiát, ezért nem érezte a szaktanácsadás szükségszerüségét, így annak hiányát sem. Ezáltal az első hipotézis erre vonatkozó része elvetésre került.

\section{7. ábra: A precíziós gazdálkodás elterjedését gátló tényezők}

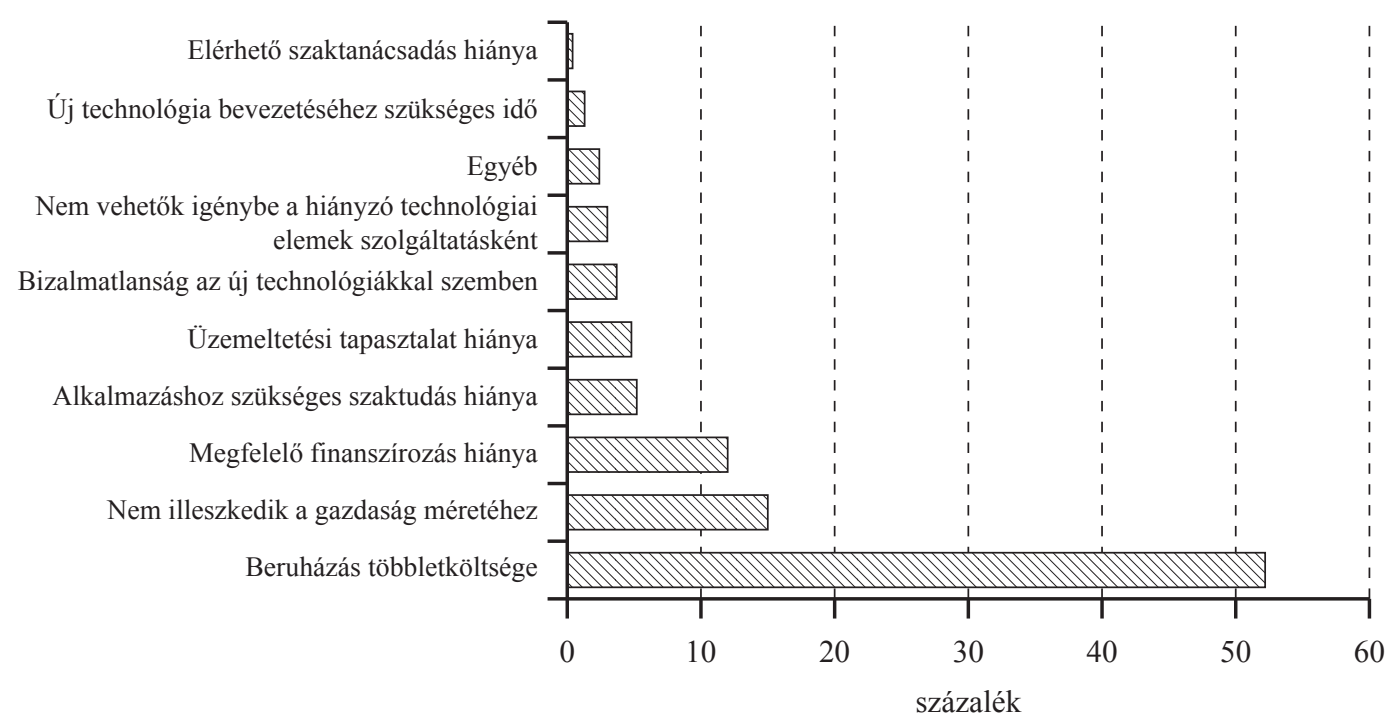

Forrás: Kérdőíves felmérés adatai alapján készült az AKI Horizontális Elemzési Osztályán

A talajkímélő mủvelést korábban még nem alkalmazó gazdálkodók szerint az üzemeltetési tapasztalat hiánya jelentősebben hátráltatja az elterjedést, mint a precíziós növénytermesztés bevezetése esetében, illetve nagyobb arányban (9,8 százalék) azonosították visszatartó erőként az új technológia bevezetéséhez szükséges idő hosszát (1. melléklet).

A precíziós növénytermesztés bevezetését elösegítő tényezők esetében 425, míg a talajkímélő mủvelésre való áttérést támogató elemekre 370 értékelhető kitöltés érkezett. A válaszok alapján egyértelmủen megállapítható, hogy az elterjedést mindkét technológia esetében leginkább az alkalmazás hatására realizálható magasabb jövedelmezőség segítené elö. Ehhez szorosan kapcsolódik a kutatási eredményekkel alátámasztott jövedelmezőségtöbblet kimutatásának igénye, amelyet a szakirodalom is alátámaszt. A precíziós gazdálkodás elterjedését segítő tényezőket azonosítók egynegyede a termelők számára nyújtott több, illetve részletesebb információt tartja a legfontosabb tényezőnek, amely elősegítené a technológia terjedését. Az elterjedést gátló tényezőkre vonatkozó hipotézisben a második helyen szerepel a fontossági sorrendben a termelöi informá- 
cióhiány. Mivel a kérdőívre érkezett válaszok alapján szintén második helyen jelölték a gazdálkodók a nem elegendő mennyiségű információt, így ez a feltételezés is beigazolódott. A talajkímélő müvelés esetében az információhiány kevésbé fontos a válaszadók szerint (2. melléklet). Az elterjedést segítené továbbá, ha a támogatások igénylésekor előnyt jelentene a technológia használata, illetve ha magasabb felvásárlási árat szabhatnának meg az előállított termékek jobb minősége okán (8. ábra). Mivel a termelök számára biztosított információk mennyiségének növelése a válaszadók egyharmada szerint a legfontosabb tényező a precíziós gazdálkodás elterjedésének segítésében, ezáltal az első hipotézis ezen része igazolható.

\section{8. ábra: A precíziós gazdálkodás elterjedését segítő tényezők}

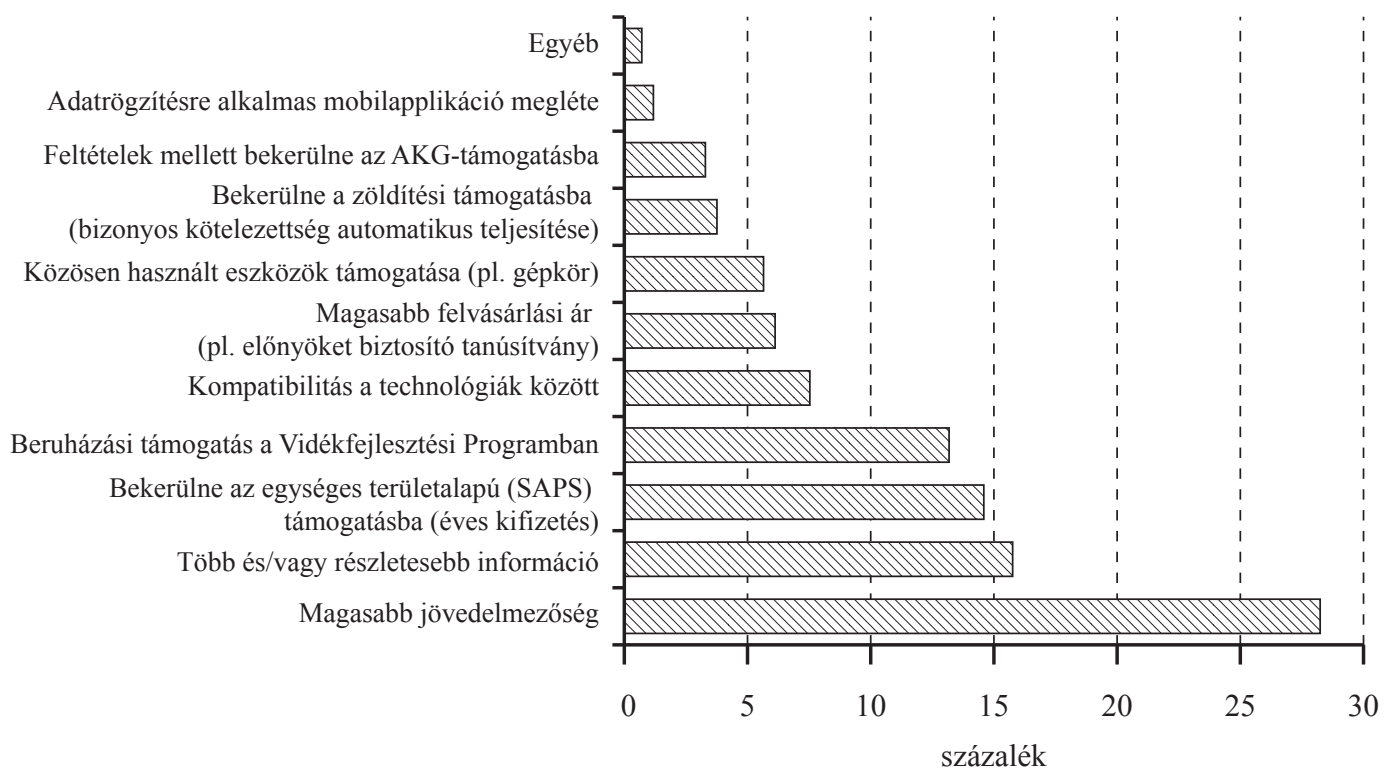

Forrás: Kérdőíves felmérés adatai alapján készült az AKI Horizontális Elemzési Osztályán

Az elemzés további részében a precíziós gazdálkodás bevezetésének, illetve alkalmazásának körülményeit vizsgáljuk, kitérve a technológia terjedésére, az agrotechnikai felszereltségre, a precíziós tevékenységek saját, illetve külső szolgáltatásban való végzésére, a föbb termesztett növénykultúrákra, a gazdálkodók által tapasztalt hatásokra, illetve a növénytermesztés gyakorlatában bekövetkezett változásokra.

\subsection{Precíziós gazdálkodást végző üzemekre vonatkozó adatok}

A vizsgált 656 kitöltő 6,9 százaléka (45 üzem) folytat precíziós gazdálkodást és a válaszadók 17,1 százaléka (112 üzem) pedig talajkímélő mủvelést (is) végez. A precíziós és/vagy talajkímélő gazdálkodók 35,3 százaléka mindkét technológiát alkalmazza, illetve a precíziós müvelést végző 45 üzem több mint 90 százaléka folytat talajkímélő mủvelést is a növénytermesztésben (9. ábra). Mivel nem lehet élesen elhatárolni a növénytermesztési gyakorlatokból származó előnyöket, így szükségszerüvé vált a technológiák együttes vizsgálata.

A 45 precíziós szántóföldi növénytermesztő gazdaság 31,1 százaléka egyáltalán nem használ RTK-korrekciót, azaz nem képes a \pm 2 centiméteres müvelési (vetési, tápanyag-kijuttatási stb.) pontosságra. A válaszadók 26,7 százaléka éves RTK-jelvételi előfizetéssel, míg 13,3 százalékuk saját RTK-bázisállomással rendelkezik, további 15,6 százalék RTK-tól eltérő korrekciót használ. A fennmaradó üzemek (8,9 százalék) adatmennyiség alapján fizetnek a korrekcióért, illetve kampányidő- 
szaki előfizetéssel rendelkeznek (2,2 százalék). Továbbá egy esetben előfordult az is, hogy a saját bázisállomás mellett éves előfizetéssel is rendelkezett a gazdálkodó.

\section{9. ábra: Precíziós gazdálkodást és/vagy talajkímélő múvelést végző üzemek megoszlása az alkalmazók körében}

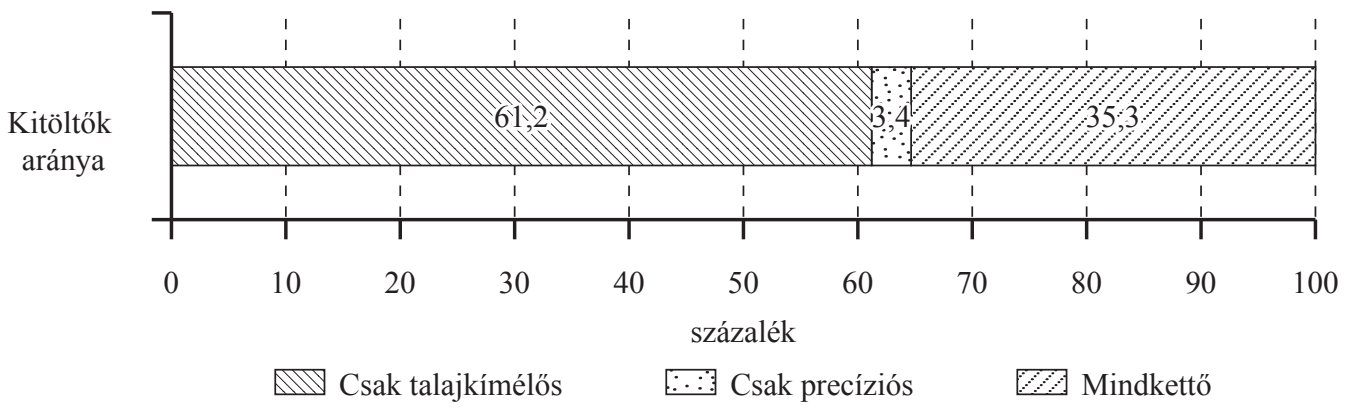

Forrás: Kérdőíves felmérés adatai alapján készült az AKI Horizontális Elemzési Osztályán

A vizsgált gazdaságokban a precíziós növénytermesztést legkorábban bevezető üzem már 2004ben megkezdte a technológia alkalmazását. Magyarországon a precíziós gazdálkodás bevezetésében 2012-ben következett be jelentős előrelépés, ekkor a vizsgált tesztüzemi körben 7 új üzem csatlakozott az alkalmazókhoz, és a precíziós növénytermesztők száma a 2012. évet követően folyamatosan növekedett. A precíziós termesztési technológiára való áttérés jellemzően 1-3 növénykultúrát érintett (válaszadók 52,4 százaléka), de jelentős volt azok száma is, akik 4-6 növény esetében alkalmaztak először precíziós növénytermesztési elemeket (kitöltők 45,2 százaléka). A mintagazdaságok közül viszont mindössze egy üzem kezdett bele a precíziós gazdálkodásba több mint hétféle növénykultúrával (10. ábra).

\section{0. ábra: A precíziós növénytermesztés bevezetésének éve és a technológia terjedése a vizsgált években}

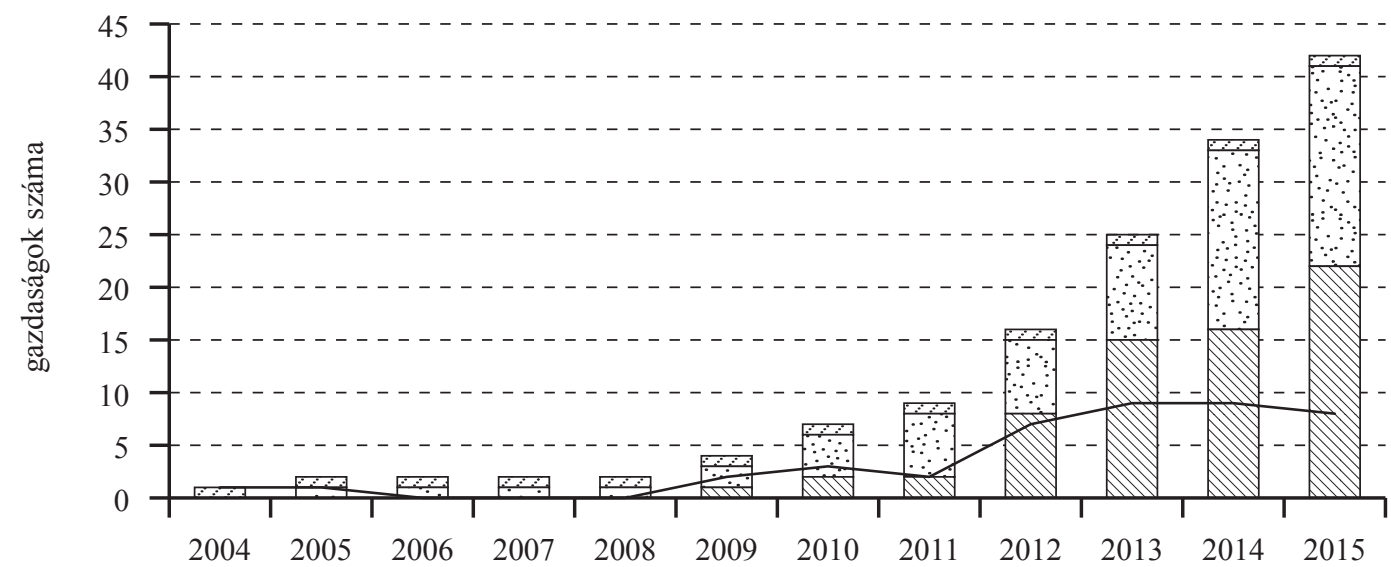

1-3 növény 4 4-6 növény $Z$ Több mint 7 növény —új precíziós üzemek

Megjegyzés: Három precíziós szántóföldi növénytermesztő gazdaság nem jelölte meg precíziós tevékenysége kezdetének dátumát, így az ábrában 42 gazdaság szerepel.

Forrás: Kérdőíves felmérés adatai alapján készült az AKI Horizontális Elemzési Osztályán 
Az elemzés további részében a precíziós gazdálkodás alkalmazásának körülményeit vizsgáljuk, kitérve az agrotechnikai felszereltségre, a precíziós tevékenységek saját, illetve külső szolgáltatásban való végzésére, a főbb termesztett növénykultúrákra, a gazdálkodók által tapasztalt hatásokra, illetve a növénytermesztés gyakorlatában bekövetkezett változásokra.

A vizsgált 45 precíziós technológiát alkalmazó üzem 274 darab erőgéppel rendelkezett. Ezen gépek 29,6 százaléka képes robotkormányzásra, 45,6 százaléka pedig fedélzeti számítógéppel való összekapcsolásra alkalmas. Az üzemekben található (282 darab) talajmüvelö gépek 5,7 százaléka kapcsolható össze fedélzeti számítógéppel és mindössze 2,1 százaléka képes munkafolyamat közben változtatható müvelésmélységre. A vetőgépek között a széles sortávú vetőgép mind darabszámban, mind precíziós technikai képességekben megelőzte a keskeny sortávút. A széles sortávú vetőgépek 56,6 százaléka fedélzeti számítógéppel összekapcsolható, egynegyede vetés közben képes változtatni a tőszámot, míg 27,6 százaléka ráfedésmentes müvelésre alkalmas. A szántóföldi növénytermesztés gyakorlatából adódóan a vizsgált üzemeknek a trágyakijuttató eszközök közül szilárdműtrágyaszóróból volt a legtöbb, melynek több mint fele köthetö össze számítógéppel, 23,0 százaléka képes a többletkijuttatást eredményező átfedések kizárására és 36,1 százaléka munkafolyamat közben tudja változtatni az anyagkijuttatást. A betakarítógépek 26,4 százaléka volt robotkormányzásra képes és 15,1 százaléka hozamtérképezésre alkalmas. A vizsgált üzemekben a vontatott permetezőgépek száma megelőzte az önjáró permetezőkét, precíziós képességben viszont fordított volt az arány. Az önjáró permetezőgépek 84,2 százaléka összekapcsolható fedélzeti számítógéppel, 57,9 százaléka képes az átfedésmentes hatóanyag-kijuttatásra és szintén ilyen arányban képesek munkafolyamat közben változtatni az anyagkijuttatást. Továbbá a gépek 47,4 százaléka munkamenet közben képes a kijuttatott növényvédő szer intenzitásának változtatására.

A precíziós technológiát alkalmazó gazdaságok 88,9 százaléka végzett táblakontúr-felvételezést, melyet nagyobb számban vettek igénybe szolgáltatásként. A precíziós növénytermesztők 32,5 százaléka kizárólag saját maga készíti el a táblahatár felvételét, míg 22,5 százalékuk alkalmazza megosztott formában a tevékenységet (saját és külső szolgáltatásban egyaránt). Ezen tevékenység magas aránya nem meglepö, hiszen a táblakontúr felvétele a technológia alkalmazásához nélkülözhetetlen, a precíziós növénytermesztés alapját képezi, ezáltal nem minősül különálló precíziós tevékenységnek. A válaszadók többsége (82,2 százaléka) precíziós talajminta-vételezést és talajtérképezést végez, melyet jellemzően már szolgáltató készít (11. ábra). A tápanyag-kijuttatási terv és az applikációs térkép készítése az üzemek 64,4 százalékára jellemző. Vetőmag-kijuttatási tervet, illetve növényvédőszer-kijuttatási tervet és a hozzájuk kapcsolódó applikációs térképeket a gazdaságok javarészt saját maguk állítják elö. Növényvédelmi felvételezést az üzemek 42,2 százaléka végez bejárással vagy drón segítségével. Érdekes módon a hozamtérképezést a kitöltők mindössze egyharmada alkalmazza, holott egyes szakirodalmak (Kalmár, 2010) alapvető precíziós növénytermesztési elemként, a helyspecifikus gazdálkodás első lépéseként említik azt. A precíziós növényállapot-felvételezés, azaz az NDVI-vegetációs index felmérése - drónnal vagy traktorra szerelt szenzorral - volt a legkevésbé jellemző a precíziós tevékenységek között, vélhetően a technológia bonyolultsága miatt.

A felmérés alapján a 2014/2015. gazdálkodási évben a precíziós szántóföldi növénytermesztő tesztüzemek együttesen 16503 hektár területet műveltek meg precíziósan. A hagyományos szántóföldi növénytermesztési gyakorlathoz hasonlóan a precíziós technológiát alkalmazó gazdálkodók az őszi búzát, a kukoricát, a napraforgót és az őszi káposztarepcét termesztik a legnagyobb területen (1. táblázat). A továbbiakban a felsorolt növénykultúrák esetében alkalmazott technológiákat vizsgáljuk. 


\section{1. ábra: Precíziós tevékenységek saját készítésben és külső szolgáltatás igénybevételével}

Precíziós növényállapot-felvételezés (NDVI-vegetációs index drónnal vagy traktorra szerelt szenzorral)

Precíziós hozamtérképezés

Vetömag-kijuttatási terv/ applikációs térkép készítése

Növényvédőszer-kijuttatási terv/ applikációs térkép készítése

Növényvédelmi felvételezés (bejárással vagy drónnal)

Tápanyag-kijuttatási terv/ applikációs térkép készítése

Precíziós talajminta-vételezés, talajtérképezés

Táblakontúr felvétele

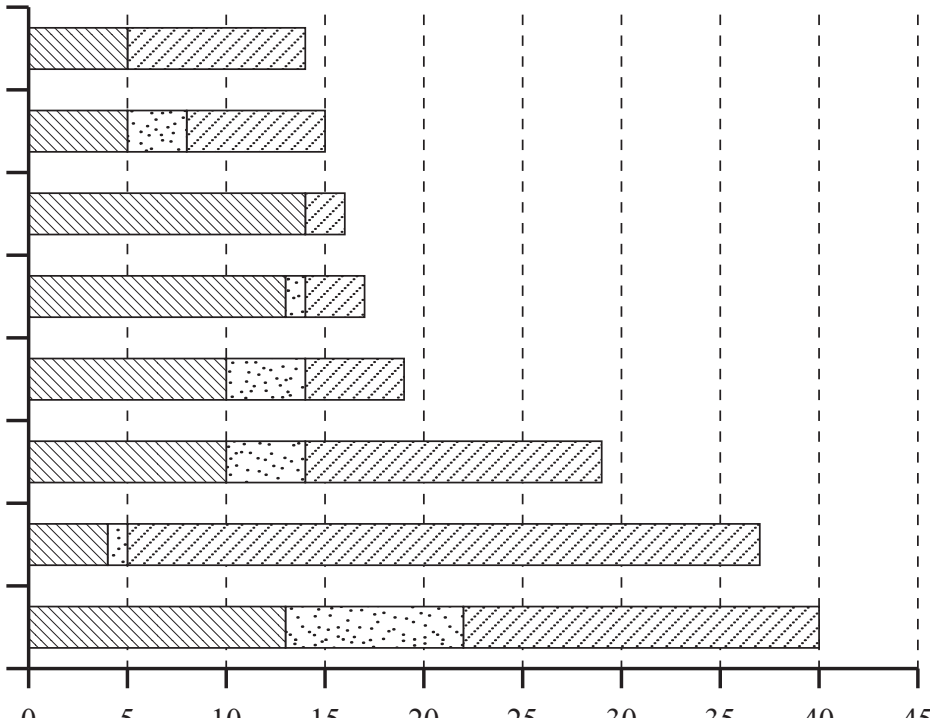

$\begin{array}{lllllllll}0 & 5 & 10 & 15 & 20 & 25 & 30 & 35 & 40\end{array}$

válaszadók száma

Csak saját készítés

Saját készítés és külső szolgáltatás igénybevétele
Csak külső szolgáltatás igénybevételével

Forrás: Kérdőíves felmérés adatai alapján készült az AKI Horizontális Elemzési Osztályán

\section{1. táblázat: Precíziós technológiával termesztett növénykultúrák és a müvelt terület} a 2014/2015. gazdálkodási évben

\begin{tabular}{lcc}
\hline \multicolumn{1}{c}{ Termesztett növénykultúra } & $\begin{array}{c}\text { Precíziós gazdálkodással müvelt } \\
\text { terület a 2014/2015. gazdálkodási } \\
\text { évben, hektár }\end{array}$ & $\begin{array}{c}\text { Precíziós technológiát alkalmazó } \\
\text { üzemek száma, darab }\end{array}$ \\
\hline Öszi búza & 4161 & 38 \\
\hline Kukorica & 4019 & 35 \\
\hline Napraforgó & 2795 & 32 \\
\hline Öszi káposztarepce & 2016 & 20 \\
\hline Őszi árpa & 825 & 15 \\
\hline Szójabab & 516 & 6 \\
\hline Egyéb szántóföldi növény & 354 & 6 \\
\hline Cukorrépa & 233 & 4 \\
\hline Tavaszi árpa & 888 & 3 \\
\hline Öszi durumbúza & 147 & 2 \\
\hline Öszi tritikálé & 63 & 2 \\
\hline Csemegekukorica & 360 & 2 \\
\hline Egyéb GOFR & 71 & 1 \\
\hline Tavaszi zab & 10 & 1 \\
\hline Rozs & 2 & 1 \\
\hline Tavaszi búza & 43 & \\
\hline
\end{tabular}

Forrás: Kérdőíves felmérés adatai alapján készült az AKI Horizontális Elemzési Osztályán 
A növénykultúrák között az őszi búza mind a müvelt terület mérete (4161 hektár), mind a termesztők száma tekintetében élen jár. A búza termesztésében a termelők 71,1 százaléka használ automata kormányzással vezérelt erőgépet. A búza tápanyag-utánpótlásában a vizsgált gazdálkodók 65,8 százaléka, vetésében 60,5 százaléka, az alkalmazott növényvédelemben 50,0 százaléka, a termőtalaj müvelésében 36,8 százaléka, illetve a termesztett növény betakarításában 23,7 százaléka végezte precíziósan tevékenységét (12. ábra). A termőterület és a növénykultúrát termesztők száma alapján a kukorica foglalja el a második helyet. A vizsgált 35 kukoricatermesztő gazdálkodás összesen több mint 4000 hektárt hasznosított.

\section{2. ábra: Az agrotechnikai tényezőkben alkalmazott precíziós technológiai elemek aránya a főbb növénykultúrákban}

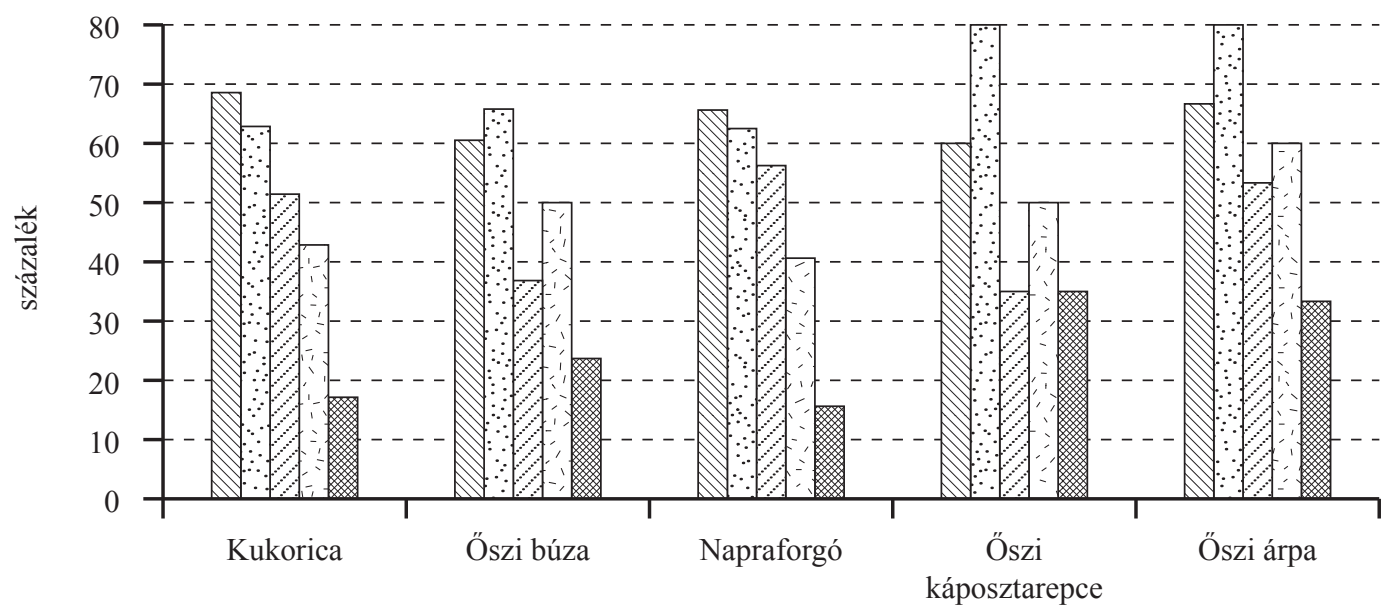

MVtés $\because$ Tápanyag-utánpótlás $\because$ Talajmüvelés $\quad \square$ Növényvédelem

Forrás: Kérdőíves felmérés adatai alapján készült az AKI Horizontális Elemzési Osztályán

A kukoricánál a gazdaságok 80,0 százaléka automata kormányzással rendelkező erőgépet használ. Az agrotechnikai tényezők közül a vetésben alkalmazták legtöbben (24 gazdaság) a helyspecifikus technológiát a növénykultúránál. A kukorica tápanyag-utánpótlását a kitöltők 62,9 százaléka, a talajmüvelést 51,4 százaléka, növényvédelmét 42,9 százaléka és a betakarítását mindössze 17,1 százaléka végezte precíziósan.

Napraforgót a mintagazdaságaink közül 32 üzem 2795 hektáron termesztett a technológiával a 2014/2015. gazdálkodási évben. A növénykultúra termesztése során az erőgépek 78,1 százalékát robotkormányzással müködtették. A napraforgónál szintén elmondható, hogy a precíziós vetés volt a legjellemzőbb (65,6 százalék), melyet a tápanyag-utánpótlás (62,5 százalék), majd a talajművelés (56,3 százalék) követett. A precíziós elemek kevésbé voltak elterjedtek a növényvédelemben, emellett a betakarításban alkalmazók száma elenyészőnek bizonyult a többi agrotechnikai tényezőhöz képest.

A nagy területen termesztett növénykultúrák közül az őszi káposztarepcét termesztették a legkevesebben (20 üzem) precíziósan, több mint 2000 hektáron. A precíziós technológia agrotechnikai elemekben való alkalmazása a fentiektől eltérően alakult. Kivételt képez ez alól az erőgépeknél használt automata kormányzás, amelyet ennél a növénynél is nagy arányban alkalmaztak, 20 precíziós növénytermesztő közül 16 automata kormányzással müködtette erőgépeit. Míg a két utóbbi növénykultúránál (kukorica, napraforgó) a különböző agrotechnikai elemekben alkalmazott precíziós technológia elterjedtségi sorrendje megegyezett, addig a repcetermesztés során használt precíziós elemek 
aránya a búzáéhoz hasonlóan alakult. A négy fő szántóföldi növénykultúra közül az őszi káposztarepce tápanyag-visszapótlásában volt a legmagasabb a precíziós technológia használatának aránya, amely elérte a 80,0 százalékot. Kiemelkedő továbbá ennél a növénynél a precíziós módon végzett betakarítás aránya, mely 35,0 százalékot tett ki.

A megkérdezett üzemek által termesztett növények közül még kiemelést érdemel az őszi árpa, a kitöltők egyharmada termesztette azt összesen 825 hektár területen. Az agrotechnikai tényezőkben alkalmazott precíziós technológiai elemek aránya az őszi árpánál a búzához és a repcéhez hasonlóan alakult.

Összegzésképpen elmondható, hogy a precíziós technológia alkalmazása a tápanyag-utánpótlásban és a vetésben volt a legjellemzőbb. Előbbi esetében a gazdaságok áltagosan 70,2 százaléka, míg utóbbinál 64,3 százaléka használt valamilyen precíziós elemet. Az alkalmazás gyakorisága tekintetében sorrendben a következő elem a növényvédelem (48,7 százalék) és a talajművelés (46,6 százalék) volt, a legkevésbé gyakorinak pedig a precíziós betakarítás bizonyult, a kitöltők egynegyede végzett mindössze precíziós tevékenységet a betakarítás során.

A főbb növényekre jellemző precíziós technológiai elemek közül az automata kormányzást követően a sorművelés, ráfedés- és kihagyásmentes vetés volt a legelterjedtebb a szántóföldi növénykultúráknál. Változó tőszámú vetést már jóval kevesebben alkalmaztak. A tápanyag-utánpótlásban szintén a sorvezető használata dominált, a kialakított zónákra történő, illetve a négyzetméterenként változó tápanyag-kijuttatás kevésbé volt elterjedt, viszont az alapműveléssel egybekötött tápanyagkijuttatás a talajmüvelésben kimagasló elemnek bizonyult. A precíziósan végzett növényvédelemben közkedvelt volt a növényvédő szer mennyiségének változtatása, ezt követte a területileg differenciált kijuttatás és a növényvédelemmel egybekötött differenciált fejtrágyázás. A betakarításban hozamtérképezést átlagosan a kitöltők 7,6 százaléka, míg a logisztikai optimalizálást 4,9 százaléka végzett.

\section{3. ábra: A precíziós technológia üzemre gyakorolt hatásai}

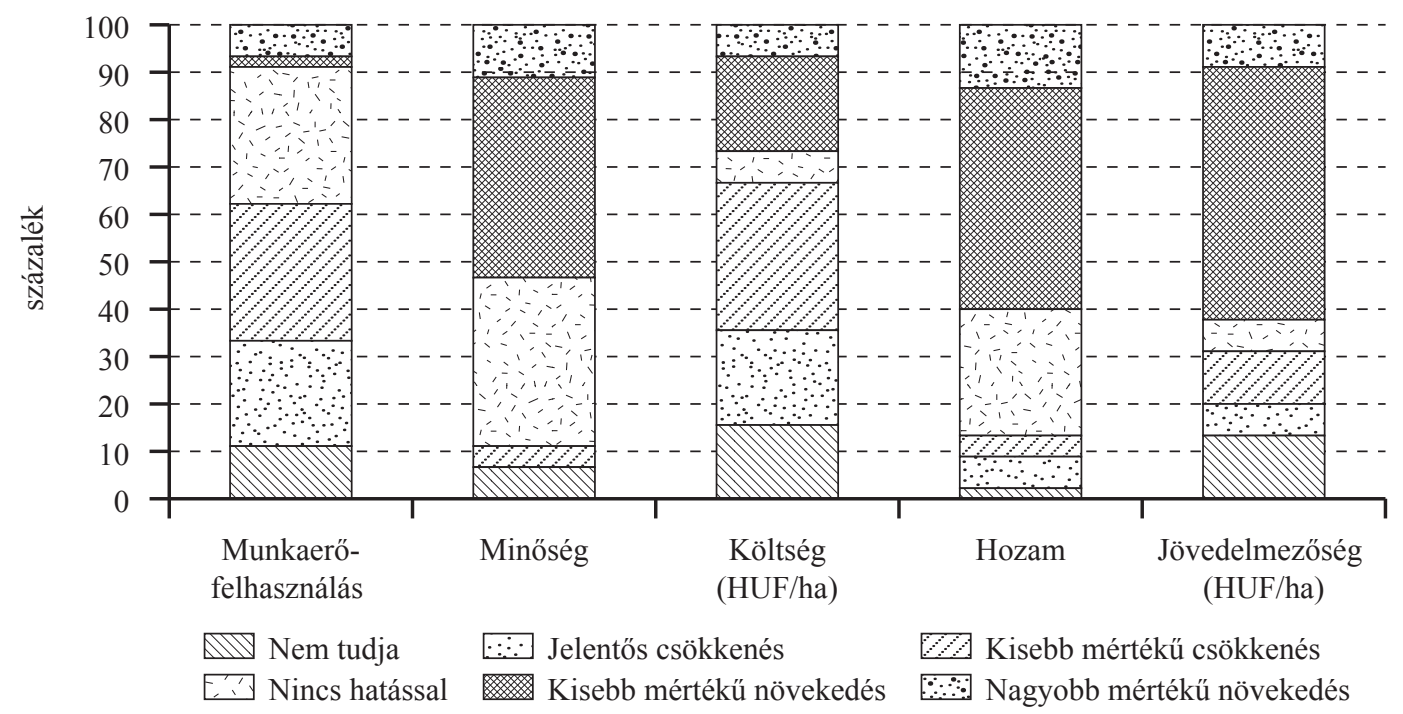

Forrás: Kérdőíves felmérés adatai alapján készült az AKI Horizontális Elemzési Osztályán

A válaszadók 31,1 százalékánál a precíziós technológia a fajlagos költségben kismértékü csökkenést eredményezett, 20,0 százalékuk jelentősebb mértékü csökkenést realizált, míg szintén 20,0 százalékuk kisebb mértékü növekedésröl számolt be (13. ábra). A jövedelmezőség tekintetében egyértelmübb volt a pozitív hatás, a válaszadók több mint fele a fajlagos jövedelmezőség kismér- 
tékü növekedéséről adott számot, míg 8,9 százalékánál nagyobb mértékü növekedés következett be a technológia hatására. A megkérdezettek 11,1 százaléka kismértékü, 6,7 százaléka pedig jelentős csökkenést tapasztalt. A munkaerö-felhasználásban a kisebb mértékü csökkenés volt számottevő, de ugyanennyi kitöltő szerint nem volt hatással a technológia a munkaerö-felhasználásra. Az egy hektárra jutó munkaóra költsége a mintagazdaságok 22,2 százalékánál jelentősen csökkent. A betakarított növénykultúrák hozamában történt változás értékelésekor kisebb mértékü növekedésről számoltak be legtöbben, nagyobb mértékü növekedés az üzemek 13,3 százalékánál volt megfigyelhető. A gazdálkodások 26,7 százaléka szerint a technológia bevezetése nincs hatással a hozamokra és elenyésző volt azon üzemek száma, amelyek kisebb mértékủ vagy akár jelentősebb hozamcsökkenést realizáltak. Az üzemek 42,2 százalékánál a minőségben kisebb mértékü növekedés következett be, 11,1 százalékánál pedig nagyobb mértékben javult a minőség. A kitöltők több mint egyharmada nem tapasztalt változást.

\section{4. ábra: Precíziós gazdálkodás bevezetésének hatása}

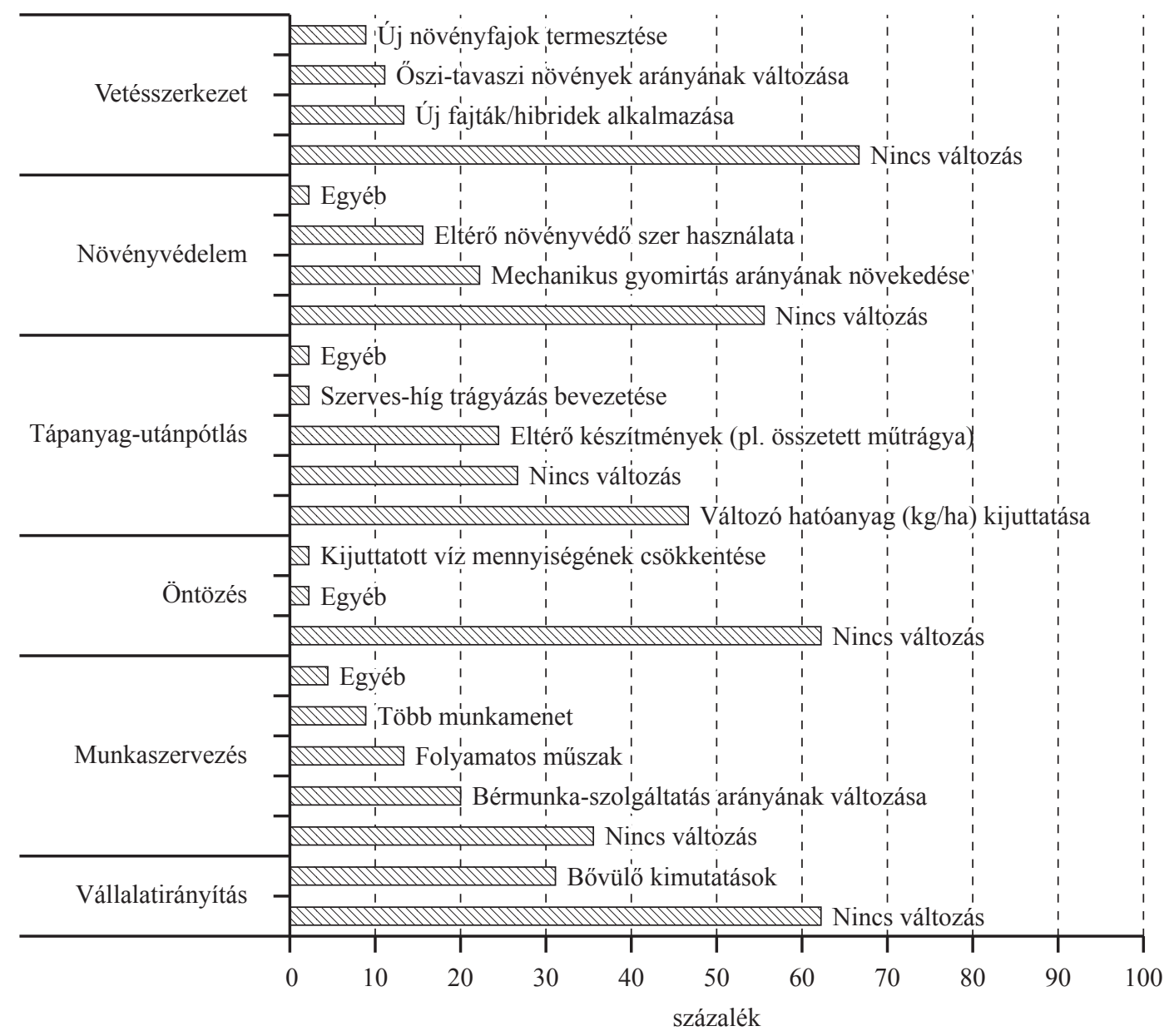

Forrás: Kérdőíves felmérés adatai alapján készült az AKI Horizontális Elemzési Osztályán

A precíziós gazdálkodást folytató üzemek többsége a vetésszerkezetben nem változtatott az új szántóföldi növénytermesztési módszer alkalmazásának hatására. A kitöltők több mint 13 százalékának új fajták, hibridek vagy új növényfajok termesztését eredményezte a technológia bevezetése, 
míg 11,1 százalékuk az őszi és a tavaszi növények arányán módosított (14. ábra). A növényvédelem gyakorlatában az általunk vizsgált gazdaságok több mint fele nem változtatott szokásain, a gazdaságok 22,2 százalékában a mechanikus gyomirtás aránya növekedett, 15,6 százalékuk pedig eltérő növényvédőszer-használatra tért át. A technológia a tápanyag-utánpótlásban az üzemek többségében változó mennyiségü hatóanyag-kijuttatást eredményezett, illetve többen áttértek eltérő készítmények használatára, míg a válaszadók 26,7 százaléka nem módosított a tápanyag-kijuttatási gyakorlatán. A növénykultúrájukat öntöző üzemek számottevő része a technológia bevezetését megelőző vízmennyiséget juttatja ki a termőterületére. A precíziós technológia alkalmazásának munkaszervezésre gyakorolt hatásai közül a bérmunka-szolgáltatás arányában tapasztalt változást a szántóföldi növénytermesztő gazdaságok 20,0 százaléka, míg 35,6 százalékuk nyilatkozott úgy, hogy a bevezetés nem volt hatással a munkaszervezésre. A technológiaváltás néhány üzemben folyamatos müszakban való munkavégzést és több munkamenetet eredményezett. A munkamenetek számának bővülése valószínủleg azon gazdaságok esetében következett be, amelyek nem rendelkeznek osztott tartályos önjáró géppel, ezáltal a tápanyag-utánpótlás monoelemeit több menetben juttatták ki. A bevezetés a gazdálkodók több mint felénél nem hozott változást a vállalatirányításban, míg közel egyharmaduk azt tapasztalta, hogy kimutatásaik bővültek.

Ahogy az már a fentiekben említésre került, vizsgálatunk tárgyát képezte a precíziós gazdálkodást folytatók mellett a talajkímélö müvelést alkalmazók köre is, illetve az általuk használt múvelési elemek és annak alkalmazásából származó hatások. A továbbiakban ezek eredményeit értékeljük.

\subsection{A talajkímélő művelési elemeket használó gazdaságok adatai}

A talajkímélő gazdálkodást végzők körében a legkedveltebb mủvelési elemnek a csökkentett menetszámú talajmüvelés bizonyult. Ez utóbbit a válaszadók 81,3 százaléka alkalmazta. Altalajlazítást és forgatás nélküli talajmüvelést végzett a kitöltők további számottevő hányada, előbbi esetében 68,8, utóbbinál 66,1 százaléka. Direktvetést a talajkímélő gazdálkodók 32,1 százaléka, mulcshagyó müvelést közel egynegyede alkalmazott (15. ábra). A sávos müvelés, a vetőkultivátoros vetés és a bakhátas mủvelés kevésbé volt elterjedt müvelési elem.

\section{5. ábra: Talajkímélő müvelési elemek használata}

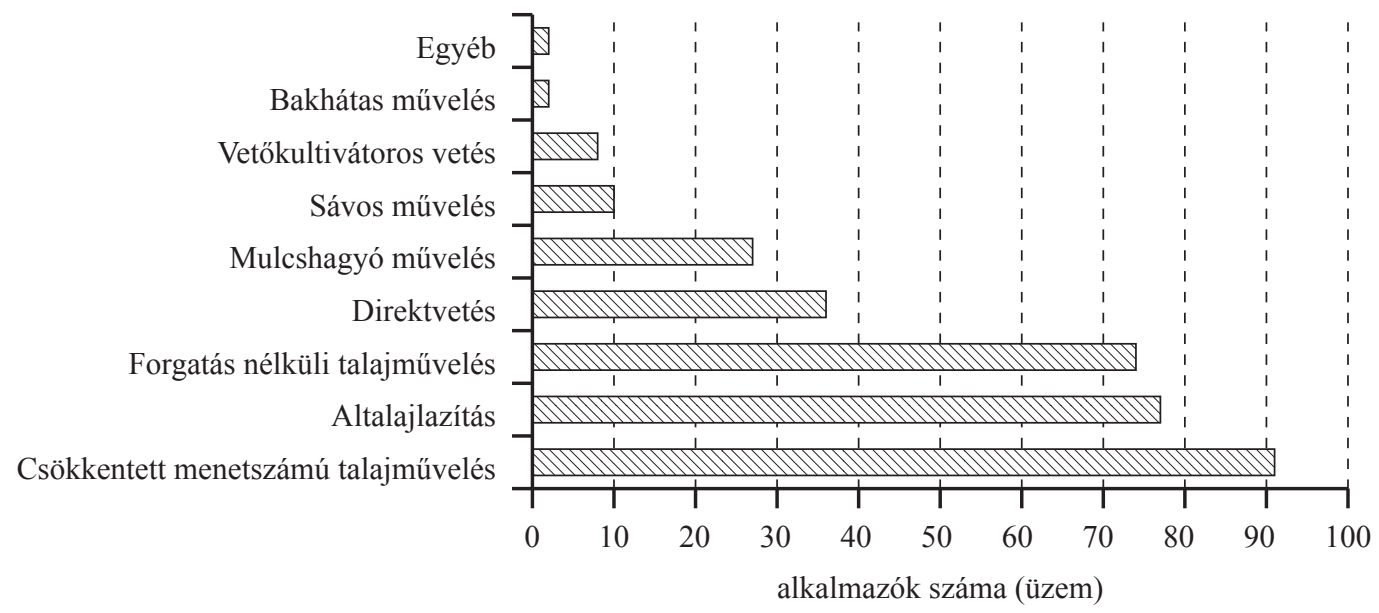

Forrás: Kérdőíves felmérés adatai alapján készült az AKI Horizontális Elemzési Osztályán

A talajkímélö müvelés a termés minőségére az alkalmazók közel fele szerint nincs hatással, mintegy negyede kisebb mértékü, 4,5 százaléka pedig jelentős mértékü növekedést tapasztalt (16. ábra). A termésminőség romlásáról kevés gazdaság számolt be. A hozam tekintetében a talajkímélő műve- 
lést végzők több mint egyharmada nem tapasztalt változást, 29,5 százaléka pedig kisebb mértékü növekedést figyelt meg. Viszonylag sokan számoltak be a hozam kisebb mértékü csökkenéséről is (a kitöltők 23,2 százaléka). A talajkímélő müvelés jövedelmezőségét a kitöltők 10,7 százaléka nem tudta felmérni. A válaszadók közel fele viszont a technológia jövedelmezőségéről adott számot, 22,3 százalékuk pedig nem észlelt javulást a jövedelmezőség tekintetében a müvelés hatására. A jövedelmezőségben kisebb mértékü csökkenést tapasztalt a gazdálkodók 13,4 százaléka, jelentős csökkenés viszont elenyésző volt. Az egy hektárra jutó költség (fajlagos költség) a gazdálkodók 44,6 százalékánál csökkent, 18,8 százalékánál pedig jelentős mértékü volt a ráfordításokban jelentkező megtakarítás. A müvelés munkaerő-felhasználásra gyakorolt hatásáról megoszlottak a vélemények. Közel azonos mértékben tapasztaltak kismértékü növekedést és változatlanságot. A válaszadók legnagyobb része (25,9 százaléka) jelentősen kevesebb munkaerővel gazdálkodott, 23,2 százalékánál kisebb mértékü csökkenés jelentkezett.

\section{6. ábra: Talajkímélő múvelés üzemre gyakorolt hatása}

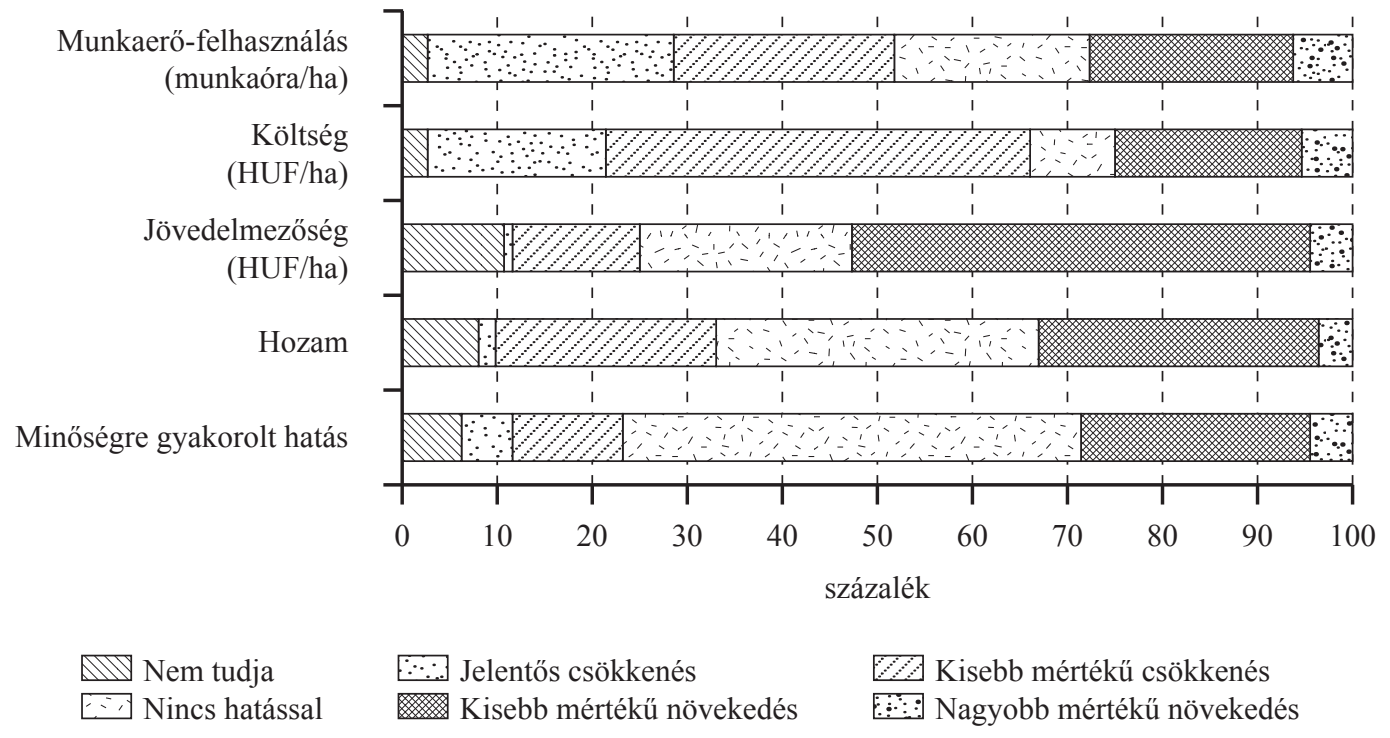




\section{A precíziós gazdálkodást végző és a hagyományosan gazdálkodó üzemek összehasonlítása}

A fejezet célja, hogy áttekintő képet nyújtson a precíziós és helyspecifikus gazdálkodást, illetve talajkímélő művelést végzö üzemek tevékenysége által elért hozamok, költségek és a jövedelmek alakulásáról a hagyományosan gazdálkodó üzemek mutatóinak tükrében. Az első részben a KITE Zrt. által rendelkezésünkre bocsátott referenciaadatok alapján a precíziós technológia által elméletben realizálható elönyök kerülnek számszerüen bemutatásra. A második részben a mélyinterjúk keretében megkérdezett gazdálkodók költség- és jövedelemmutatóit értékeljük hagyományosan gazdálkodó üzemek adataihoz viszonyítva.

\subsection{A precíziós technológia előnyei a KITE Zrt. adatai alapján}

A könyv 3. fejezetében már bemutatásra került, hogy milyen területeken jelentkezhetnek a precíziós technológia előnyei, úgymint a hozamnövekedés, a termés minőségének javulása, a hozamingadozások csökkenése, alacsonyabb inputfelhasználás (kevesebb mütrágya, vetőmag, növényvédő szer és üzemanyag), a munkaerő-felhasználás mérséklődése, alacsonyabb környezetterhelés és a magasabb jövedelem. A felsoroltak közül a technológia hozamokra és inputfelhasználásra gyakorolt hatásait a KITE Zrt. számítása szerint mutatjuk be. Az adatok tapasztalati átlagértékek, amelyek a technológia helyes és megfelelő színvonalú alkalmazása esetén jelentkeznek. A gyakorlatban jelentkező előnyök - mint azt a következő alfejezetben látni fogjuk - az időjárási feltételek, a technológiai körülmények, a vetésforgó, a talajtípus függvényében kisebb, de akár nagyobb mértékben is eltérhetnek az itt bemutatottaktól. A precíziós gazdálkodás hozadékait a négy fö növény (búza, kukorica, napraforgó, repce) esetében külön-külön mutatjuk be, összevetve a hagyományos intenzív gazdálkodással.

Az őszi búzánál a hagyományos technológia hektáronkénti 306,3 ezer forintos termelési költségéhez képest a precíziós gazdálkodás 10,6 ezer forinttal alacsonyabb, 295,7 ezer forintos termelési költséget eredményez. A megtakarítás teljes egészében az anyagköltségnél keletkezik. Felmerül ugyanakkor a precíziós szaktanácsadás 2,0 ezer forintos díja, amely a hagyományos technológiánál nem merül fel. Az anyagköltségeken belül a mütrágya-felhasználás csökken a fejlettebb eljárásnak köszönhetően, amely így az alaptrágyázásban 30 százalékos (9,5 ezer forint), a folyékony trágya esetében pedig 10 százalékos (2,1 ezer forint) költségmegtakarítást jelent. Összességében a hektáronkénti tápanyagköltség 22,0 százalékkal, vagyis egyötödével alacsonyabb, miközben a vetőmag- és növényvédőszer-felhasználás, valamint a gépi költségek nem módosulnak a technológiaváltás hatására. A precíziós gazdálkodás 3,5 százalékos költségmegtakarítást jelent. Az öszi búza hozama a modernebb technológiának köszönhetően a hektáronkénti 6,3 tonnáról 6,5 tonnára nőtt, vagyis 3,2 százalékkal emelkedett.

Azonos piaci árral (45,0 ezer forint) számolva hektáronként 283,5 ezer forint árbevétel keletkezik hagyományos gazdálkodásnál, miközben a helyspecifikus mủvelésnél 292,5 ezer forint. Az árbevételt - az alkalmazott technológiától függetlenül - 70,0 ezer forint területalapú támogatás egészíti ki, így ez utóbbi esetben 362,5 ezer forint termelési érték képződik, 9,0 ezer forinttal magasabb, mint a nem precíziós technológiánál. A termelési költség levonását követően a hagyományos technológiánál 47,2 ezer forint, a precíziós gazdálkodásnál 66,8 ezer forint jövedelem keletkezik, vagyis a modernebb technológia eredményeként az őszi búza termesztésében 14,5 százalékkal magasabb nyereség képződik (2. táblázat).

Amennyiben - tisztán a technológiai különbségek szemléltetése céljából - figyelmen kívül hagyjuk a földbérleti díjat és a támogatásokat, úgy a hagyományos technológiával 57,2 ezer forint, a precízióssal 76,8 ezer forint jövedelem realizálható, vagyis az őszi búza termesztésében a helyspecifikus 
eljárás 34,3 százalékkal több nyereséget eredményez. Ökonómiai szempontból kedvező továbbá, hogy a fedezeti pont már 6,6 tonnás hektáronkénti termés mellett elérhető, szemben a hagyományos technológia 6,8 tonnájával, illetve a költségarányos jövedelem is közel másfélszeres a hagyományos gazdaságokhoz képest.

2. táblázat: Az őszi búza költség- és jövedelemadatai a hagyományos intenzív és precíziós technológiáknál barna erdőtalaj esetén

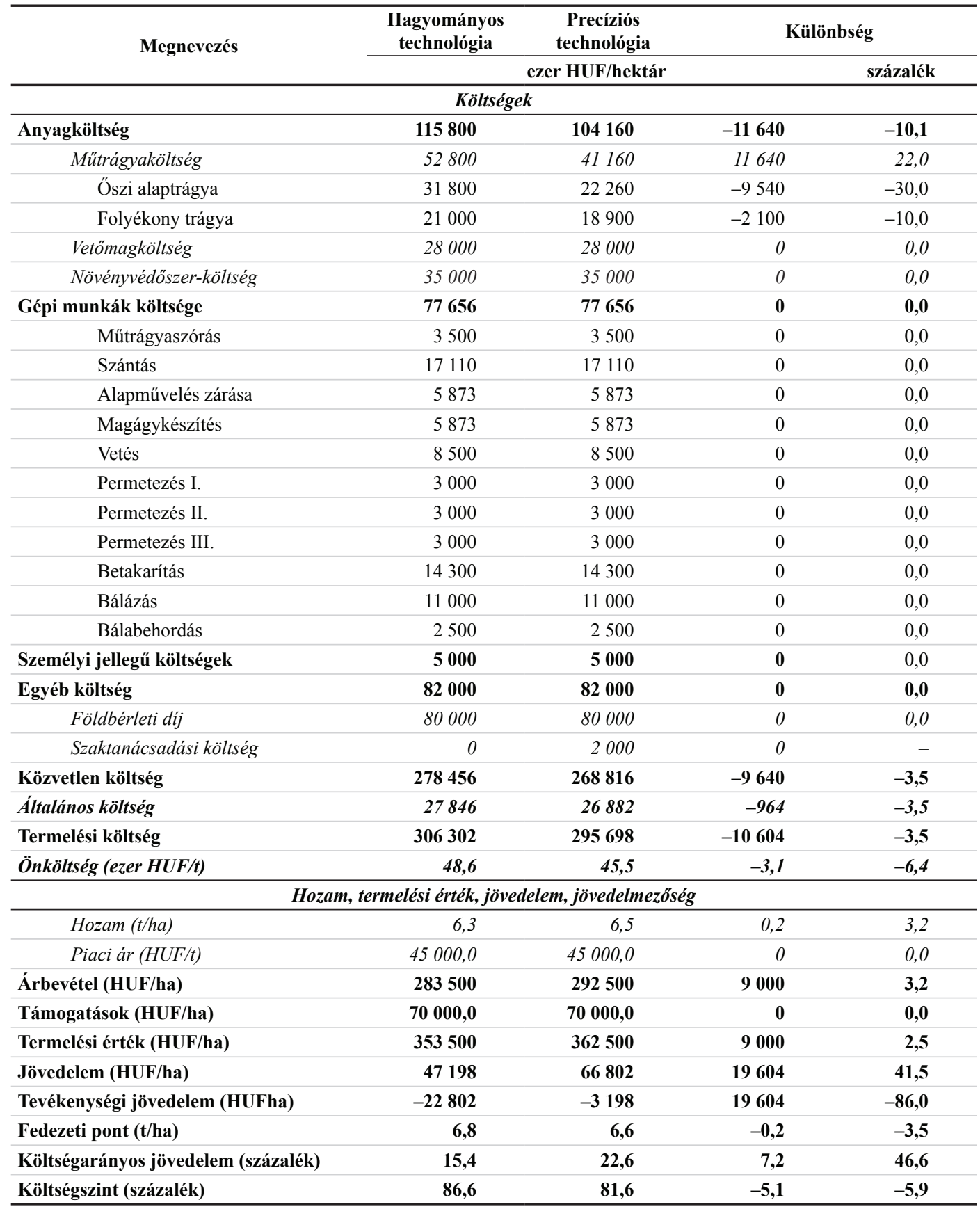

Forrás: KITE Zrt. 
A kukoricatermesztésben a precíziós technológia nemcsak a mütrágya és a gépi munkák költségében okoz eltéréseket a hagyományos technológiához képest, hanem a vetőmagnál is, igaz, számottevő előny az őszi búzához hasonlóan itt is a mütrágya-felhasználásnál jelentkezik. A kukorica hektáronkénti termelési költsége a helyspecifikus eljárásnál 367,2 ezer forint, földbérleti díjat is figyelembe véve. Ez a hagyományos technológia hektáronkénti 376,2 ezer forintos termelési költségéhez képest 8,9 ezer forinttal alacsonyabb. A megtakarítás nagyrészt az alacsonyabb alaptrágya- és folyékonytrágya-felhasználásnak köszönhetö, amely 12,0 ezer forinttal alacsonyabb költséget jelent, de a vetömag-felhasználás is mérséklődik 1,2 ezer forinttal. Nő ugyanakkor a gépi munkák költsége 3,0 ezer forinttal, mivel a helyspecifikus gazdálkodásnál eggyel többször kerül sor permetezésre, illetve felmerül a precíziós szaktanácsadás költsége. A növényvédőszer-felhasználás a kukoricánál is változatlan. A precíziós technológia az őszi búzához képest 1,3 százalékponttal alacsonyabb, 2,4 százalékos költségmegtakarítást jelent.

A hagyományos technológia eredményeként 9,0, a helyspecifikus gazdálkodásnál 9,4 tonnás termésátlag képződik, amely 4,4 százalékos hozambővülést jelent. A kukorica 45,0 ezer forintos piaci ára mellett 405,0, illetve 423,0 ezer forint a fajlagos árbevétel, amely a 70,0 ezer forintos támogatással együtt 475,0 és 493,0 ezer forint termelési értéket jelent. A különbség 18,0 ezer forint a precíziós gazdálkodás javára. A hagyományos technológia költség- és hozamszintje 98,8 ezer forint jövedelem realizálását teszi lehetővé, miközben a helyspecifikus technológiáé 27,3 százalékkal magasabbat, 125,8 ezer forintot (3. táblázat).

A földbérleti díjat és a támogatásokat nem számítva a hagyományos technológiával 108,8 ezer forint, a precízióssal 135,8 ezer forint nyereség érhető el, vagyis a kukoricánál a helyspecifikus eljárás 24,8 százalékkal magasabb jövedelemszintet eredményez. A fedezeti pontot jelentő termésátlag 6,6 tonna a helyspecifikus gazdálkodásnál, 6,8 tonna a hagyományosnál. A költségarányos jövedelem 8,0 százalékponttal magasabb, 34,3 százalék a precíziós eljárásnál.

A napraforgónál a hagyományos technológia 325,2 ezer forintos termelési költsége áll szemben a helyspecifikus müvelés 315,3 ezer forintos hektáronkénti értékével. A különbség abszolút értékben kevesebb mint 10,0 ezer forint, százalékosan pedig 3,0 százalék, amely magasabb, mint a kukoricánál tapasztalt költségelőny, de alacsonyabb, mint az őszi búzáé. A költségelőnyök megint csak a tápanyag-utánpótlásban a leginkább érzékelhetők, ott 11,0 ezer forintos megtakarítás keletkezik, amely a teljes mütrágyaköltség 23,2 százaléka. A növényvédő szer és a vetőmag felhasználása, valamint a gépi munkák költsége a napraforgónál is változatlan, ráfordításnövekedés egyedül a szaktanácsadási költségnél tapasztalható.

A hagyományos technológia esetében 3,0, a helyspecifikus gazdálkodásnál 3,2 tonnás hozamot realizálnak a gazdák, amely 5 százalékkal magasabb átlagtermést jelent. A napraforgó tonnánkénti önköltsége 108,4 ezer forint a hagyományos müvelésnél, és ennél 8,3 ezer forinttal alacsonyabb a helyspecifikus gazdálkodásnál.

A napraforgó-termesztésben 102,0 ezer forintos piaci ár mellett hektáronként 306,0 ezer forint árbevétel keletkezik a hagyományos technológia alkalmazásával, 321,3 ezer forint a modernebb eljárásnál, amelyhez hozzájön a 70,0 ezer forintos támogatás. Vagyis 391,3 ezer forint termelési érték keletkezik a precíziós gazdálkodás esetében, amely 15,3 ezer forinttal magasabb, mint a hagyományos technológiánál. Összességében a napraforgó jövedelme a pontosabb eljárásoknak köszönhetően 25,2 ezer forinttal magasabb hektáronként, 76,0 ezer forint. Az említett eltérés nagyságrendileg másfélszer nagyobb nyereséget jelent (4. táblázat). 
3. táblázat: A kukorica költség- és jövedelemadatai a hagyományos intenzív és a precíziós technológiáknál barna erdőtalaj esetén

\begin{tabular}{|c|c|c|c|c|}
\hline \multirow{2}{*}{ Megnevezés } & \multirow{2}{*}{$\begin{array}{c}\text { Hagyományos } \\
\text { technológia }\end{array}$} & \multirow{2}{*}{$\begin{array}{c}\begin{array}{c}\text { Precíziós } \\
\text { technológia }\end{array} \\
\text { ezer HUF/hektár }\end{array}$} & \multicolumn{2}{|c|}{ Különbség } \\
\hline & & & & százalék \\
\hline \multicolumn{5}{|c|}{ Költségek } \\
\hline Anyagköltség & 141304 & 128173 & -13131 & $-9,3$ \\
\hline Mütrágyaköltség & 69126 & 57173 & -11953 & $-17,3$ \\
\hline Öszi alaptrágya & 31200 & 21840 & -9360 & $-30,0$ \\
\hline Starter trágya & 12000 & 12000 & 0 & 0,0 \\
\hline Folyékony trágya & 25926 & 23333 & -2593 & $-10,0$ \\
\hline Vetömagköltség & 30178 & 29000 & -1178 & $-3,9$ \\
\hline Növényvédöszer-költség & 42000 & 42000 & 0 & 0,0 \\
\hline Gépi munkák költsége & 115663 & 118663 & 3000 & 2,6 \\
\hline Kémiai tarlóápolás & 3000 & 3000 & 0 & 0,0 \\
\hline Mütrágyaszórás & 3500 & 3500 & 0 & 0,0 \\
\hline Szántás & 17110 & 17110 & 0 & 0,0 \\
\hline Alapmüvelés zárása & 5873 & 5873 & 0 & 0,0 \\
\hline Vetés & 15000 & 15000 & 0 & 0,0 \\
\hline Permetezés I. & 3000 & 3000 & 0 & 0,0 \\
\hline Kultivátorozás I. & 9000 & 9000 & 0 & 0,0 \\
\hline Kultivátorozás II. & 9000 & 9000 & 0 & 0,0 \\
\hline Permetezés II. & 3000 & 3000 & 0 & 0,0 \\
\hline Permetezés III. & & 3000 & 3000 & - \\
\hline Betakarítás & 18830 & 18830 & 0 & 0,0 \\
\hline Szárítás & 28350 & 28350 & 0 & 0,0 \\
\hline Személyi jellegű költségek & 5000 & 5000 & $\mathbf{0}$ & $\mathbf{0 , 0}$ \\
\hline Egyéb költség & 82000 & 82000 & $\mathbf{0}$ & $\mathbf{0 , 0}$ \\
\hline Földbérleti díj & 80000 & 80000 & 0 & 0,0 \\
\hline Szaktanácsadási költség & 0 & 2000 & 0 & - \\
\hline Közvetlen költség & 341967 & 333836 & -8131 & $-2,4$ \\
\hline Általános költség & 34197 & 33384 & -813 & $-2,4$ \\
\hline Termelési költség & 376164 & 367220 & -8944 & $-2,4$ \\
\hline Önköltség (ezer HUF/t) & 41,8 & 39,1 & $-2,7$ & $-6,5$ \\
\hline \multicolumn{5}{|c|}{ Hozam, termelési érték, jövedelem, jövedelmezőség } \\
\hline $\operatorname{Hozam}(t / h a)$ & 9,0 & 9,4 & 0,4 & 4,4 \\
\hline Piaci ár $(H U F / t)$ & 45000,0 & 45000,0 & 0 & 0,0 \\
\hline Árbevétel (HUF/ha) & 405000 & 423000 & 18000 & 4,4 \\
\hline Támogatások (HUF/ha) & 70000,0 & 70000,0 & $\mathbf{0}$ & $\mathbf{0 , 0}$ \\
\hline Termelési érték (HUF/ha) & 475000 & 493000 & 18000 & 3,8 \\
\hline Jövedelem (HUF/ha) & 98836 & 125780 & 26944 & 27,3 \\
\hline Tevékenységi jövedelem (HUF/ha) & 28836 & 55780 & 26944 & 93,4 \\
\hline Fedezeti pont (t/ha) & 8,4 & 8,2 & $-0,2$ & $-2,4$ \\
\hline Költségarányos jövedelem (százalék) & 26,3 & 34,3 & 8,0 & 30,4 \\
\hline Költségszint (százalék) & 79,2 & 74,5 & $-4,7$ & $-\mathbf{5 , 9}$ \\
\hline
\end{tabular}

Forrás: KITE Zrt. 
A földbérleti díj és a támogatások nélkül 60,8 ezer forint nyereség képződik a hagyományos technológiával és 86,0 ezer forint a precízióssal. A helyspecifikus gazdálkodásnál 41,3 százalékkal érhető el nagyobb nyereség a napraforgó-termesztésben. A fedezeti pontot jelentő termésátlag 3,2 tonna a hagyományos gazdálkodásnál, ennél 0,1 tonnával alacsonyabb a helyspecifikus müvelésnél. A költségarányos jövedelem 8,5 százalékponttal magasabb, 24,1 százalék a precíziós eljárásnál.

4. táblázat: A napraforgó költség- és jövedelemadatai a hagyományos intenzív és a precíziós technológiáknál barna erdőtalaj esetén

\begin{tabular}{|c|c|c|c|c|}
\hline \multirow{2}{*}{ Megnevezés } & Hagyományos & Precíziós & \multicolumn{2}{|c|}{ Különbség } \\
\hline & \multicolumn{3}{|c|}{ ezer HUF/hektár } & százalék \\
\hline \multicolumn{5}{|c|}{ Költségek } \\
\hline Anyagköltség & 131274 & 120319 & -10955 & $-8,3$ \\
\hline Mütrágyaköltség & 47154 & 36199 & -10955 & $-23,2$ \\
\hline Öszi alaptrágya & 31200 & 21840 & -9360 & $-30,0$ \\
\hline Folyékony trágya & 15954 & 14359 & -1595 & $-10,0$ \\
\hline Vetömagköltség & 21120 & 21120 & 0 & 0,0 \\
\hline Növényvédőszer-költség & 63000 & 63000 & 0 & 0,0 \\
\hline Gépi munkák költsége & 79333 & 79333 & $\mathbf{0}$ & $\mathbf{0 , 0}$ \\
\hline Kémiai tarlóápolás & 3000 & 3000 & 0 & 0,0 \\
\hline Mủtrágyaszórás & 3500 & 3500 & 0 & 0,0 \\
\hline Szántás & 17110 & 17110 & 0 & 0,0 \\
\hline Alapmüvelés zárása & 5873 & 5873 & 0 & 0,0 \\
\hline Magágykészítés & 0 & 0 & 0 & - \\
\hline Permetezés I. & 3000 & 3000 & 0 & 0,0 \\
\hline Vetés & 14000 & 14000 & 0 & 0,0 \\
\hline Permetezés II. & 3000 & 3000 & 0 & 0,0 \\
\hline Kultivátorozás & 9000 & 9000 & 0 & 0,0 \\
\hline Permetezés, 3 alkalommal & 9000 & 9000 & 0 & 0,0 \\
\hline Betakarítás & 11850 & 11850 & 0 & 0,0 \\
\hline Szárítás & 0 & 0 & 0 & - \\
\hline Személyi jellegü költségek & 5000 & 5000 & 0 & $\mathbf{0 , 0}$ \\
\hline Egyéb költség & 80000 & 82000 & 2000 & 2,5 \\
\hline Földbérleti dij & 80000 & 80000 & 0 & 0,0 \\
\hline Szaktanácsadási költség & 0 & 2000 & 2000 & - \\
\hline Közvetlen költség & 295607 & 286652 & -8955 & $-3,0$ \\
\hline Altalános költség & 29561 & 28665 & -896 & $-3,0$ \\
\hline Termelési költség & 325168 & 315317 & -9851 & $-3,0$ \\
\hline Önköltség (ezer HUF/t) & 108,4 & 100,1 & $-8,3$ & $-7,6$ \\
\hline \multicolumn{5}{|c|}{ Hozam, termelési érték, jövedelem, jövedelmezőség } \\
\hline Hozam $(t / h a)$ & 3,0 & 3,2 & 0,2 & 5,0 \\
\hline Piaci ár $(H U F / t)$ & 102000 & 102000 & 0 & 0,0 \\
\hline Árbevétel (HUF/ha) & 306000 & 321300 & 15300 & 5,0 \\
\hline Támogatások (HUF/ha) & 70000 & 70000 & $\mathbf{0}$ & $\mathbf{0 , 0}$ \\
\hline Termelési érték (HUF/ha) & 376000 & 391300 & 15300 & 4,1 \\
\hline Jövedelem (HUF/ha) & 50832 & 75983 & 25151 & 49,5 \\
\hline Tevékenységi jövedelem (HUF/ha) & -19168 & 5983 & 25151 & $-131,2$ \\
\hline Fedezeti pont (t/ha) & 3,2 & 3,1 & $-0,1$ & $-3,0$ \\
\hline Költségarányos jövedelem (százalék) & 15,6 & 24,1 & $-8,5$ & 54,1 \\
\hline Költségszint (százalék) & 86,5 & 80,6 & $-5,9$ & $-6,8$ \\
\hline
\end{tabular}

Forrás: KITE Zrt. 
5. táblázat: A repce költség- és jövedelemadatai a hagyományos intenzív és precíziós technológiáknál barna erdőtalaj esetén

\begin{tabular}{|c|c|c|c|c|}
\hline \multirow{2}{*}{ Megnevezés } & \multirow{2}{*}{$\begin{array}{c}\text { Hagyományos } \\
\text { technológia }\end{array}$} & \multirow{2}{*}{$\begin{array}{c}\begin{array}{c}\text { Precíziós } \\
\text { technológia }\end{array} \\
\text { er HUF/hektál }\end{array}$} & \multicolumn{2}{|c|}{ Különbség } \\
\hline & & & & százalék \\
\hline \multicolumn{5}{|c|}{ Költségek } \\
\hline Anyagköltség & 142633 & 126592 & -16041 & $-11,2$ \\
\hline Mütrágyaköltség & 52200 & 36159 & -16041 & $-30,7$ \\
\hline Öszi alaptrágya & 31200 & 21800 & -9400 & $-30,1$ \\
\hline Folyékony trágya & 21000 & 14359 & -6641 & $-31,6$ \\
\hline Vetömagköltség & 30433 & 30433 & 0 & 0,0 \\
\hline Növényvédőszer-költség & 60000 & 60000 & 0 & 0,0 \\
\hline Gépi munkák költsége & 70223 & 70223 & 0 & 0,0 \\
\hline Kémiai tarlóápolás & 3000 & 3000 & 0 & 0,0 \\
\hline Mütrágyaszórás & 3500 & 3500 & 0 & 0,0 \\
\hline Forgatás nélküli alapmüvelés & 12500 & 12500 & 0 & 0,0 \\
\hline Magágykészítés & 5873 & 5873 & 0 & 0,0 \\
\hline Permetezés I. & 3000 & 3000 & 0 & 0,0 \\
\hline Vetés & 8500 & 8500 & 0 & 0,0 \\
\hline Permetezés II. & 3000 & 3000 & 0 & 0,0 \\
\hline Kultivátorozás & 9000 & 9000 & 0 & 0,0 \\
\hline Permetezés, 3 alkalommal & 9000 & 9000 & 0 & 0,0 \\
\hline Betakarítás & 12850 & 12850 & 0 & 0,0 \\
\hline Szárítás & 0 & 0 & 0 & - \\
\hline Személyi jellegü költségek & 5000 & 5000 & $\mathbf{0}$ & $\mathbf{0 , 0}$ \\
\hline Egyéb költség & 80000 & 82000 & 2000 & 2,5 \\
\hline Földbérleti díj & 80000 & 80000 & 0 & 0,0 \\
\hline Szaktanácsadási költség & 0 & 2000 & 2000 & - \\
\hline Közvetlen költség & 297856 & 283815 & -14041 & $-4,7$ \\
\hline Általános költség & 29786 & 28382 & -1404 & $-4,7$ \\
\hline Termelési költség & 327642 & 312197 & -15445 & $-4,7$ \\
\hline Önköltség (ezer HUF/t) & 109,2 & 99,1 & $-10,1$ & $-9,3$ \\
\hline \multicolumn{5}{|c|}{ Hozam, termelési érték, jövedelem, jövedelmezőség } \\
\hline Hozam $(t / h a)$ & 3,0 & 3,2 & 0,2 & 5,0 \\
\hline Piaci ár $(H U F / t)$ & 110000,0 & 110000,0 & 0 & 0,0 \\
\hline Árbevétel (HUF/ha) & 330000 & 346500 & 16500 & 5,0 \\
\hline Támogatások (HUF/ha) & 70000 & 70000 & $\mathbf{0}$ & $\mathbf{0 , 0}$ \\
\hline Termelési érték (HUF/ha) & 400000 & 416500 & 16500 & 4,1 \\
\hline Jövedelem (HUF/ha) & 72358 & 104304 & 31945 & 44,1 \\
\hline Tevékenységi jövedelem (HUF/ha) & 2358 & 34304 & 31945 & 1354,5 \\
\hline Fedezeti pont (t/ha) & 3,0 & 2,8 & $-0,1$ & $-4,7$ \\
\hline Költségarányos jövedelem (százalék) & 22,1 & 33,4 & 11,3 & 51,3 \\
\hline Költségszint (százalék) & 81,9 & 75,0 & $-7,0$ & $-8,5$ \\
\hline
\end{tabular}

Forrás: KITE Zrt.

A hektáronkénti termelési költség a repcénél hagyományos termelési mód mellett 327,6 ezer forint, miközben helyspecifikus gazdálkodással 312,2 ezer forint. A különbség abszolút értékben 15,4 ezer forint, a vizsgált négy növény közül a legmagasabb. A megtakarítás az egyes ráfordításele- 
mek közül megint csak a mütrágya-felhasználásban jelentkezik, ahol 16,0 ezer forint a költségelőny, a teljes tápanyag-utánpótlás 30,7 százaléka. A vetőmag és növényvédő szer, valamint a gépi munkák költsége azonos a kétféle müvelési mód esetében, növekedést a ráfordításokban a szaktanácsadás okoz. Összességében a költségek 4,7 százaléka „spórolható meg” a pontosabb gazdálkodással, amely arányszám a vizsgált növények körében - csakúgy, mint abszolút értékben - a repcénél a legmagasabb.

A repce termésátlaga 3,0 tonna hektáronként a hagyományos gazdálkodásnál, 3,2 tonna a modern technológiánál, az eltérés 5 százalék. Az árbevétel 110,0 ezer forintos piaci ár mellett hektáronként rendre 330,0 és 346,5 ezer forint. A 70,0 ezer forint összegü támogatással együtt 400,0 ezer forint termelési érték keletkezik a hagyományos gazdaságokban és ennél 16,5 ezer forinttal magasabb a precíziós technológiánál. A költségek levonása után a hagyományos termelésnél 72,4 ezer forint nyereség marad, a helyspecifikusnál 104,3 ezer forint. A fentiekből adódóan a jövedelemtöbblet abszolút értékben is a repcénél a legnagyobb, 32,0 ezer forint, százalékosan 44,1 százalék (5. táblázat).

A földbérleti díjat és a támogatásokat figyelmen kívül hagyva hagyományos technológiával 82,4 ezer forint, a precízióssal 114,3 ezer forint nyereség érhető el, vagyis a repcénél a helyspecifikus eljárás 38,8 százalékkal magasabb jövedelemszintet eredményez. A bevételek és ráfordítások 3,0 tonnás termésátlagnál egyeznek meg a hagyományos mủvelés esetében és ennél 0,2 tonnával alacsonyabb szinten a precíziós technológiánál. A költségarányos jövedelem 33,4 százalék a helyspecifikus művelésnél és 22,1 százalék a hagyományos termelésnél.

\subsection{A mintaüzemek föbb jellemzői és gazdálkodási tapasztalataik}

Kutatásunk keretében több olyan precíziós és helyspecifikus gazdálkodást végző üzemet felkerestünk, amelyek elvileg megfeleltek kutatási céljainknak. Az előzetes vizsgálatok és szakmai konzultációk eredményeképpen végül három üzemnél - ezeket hívjuk mintaüzemnek - készítettünk mélyinterjúkat:

- Bács-Kiskun megyei mintaüzem,

- Zala megyei mintaüzem, és

- Somogy megyei mintaüzem.

A kiválasztott mintaüzemek rendelkeztek azzal a potenciállal, amely alkalmassá tette őket kutatási céljaink eléréséhez. A mintaüzemek földrajzilag differenciáltan helyezkednek el Magyarország területén, azaz különböző gazdasági, környezeti és egyéb jellemzőkkel rendelkeznek, ami biztosítja a heterogenitást.

Az alfejezet célja, hogy röviden bemutassa a kiválasztott mintaüzemeket, koncentrálva a precíziós és helyspecifikus gazdálkodás tényezőire.

A Bács-Kiskun megyei mintaüzem a Dél-Alföldön található. Az egyéni vállalkozásként müködő gazdaságban 2010 és 2015 között átlagosan 335 hektáron folytattak mezőgazdasági termelést. A mezőgazdasági terület teljes egészét bérlőként használják. Az alkalmazott éves munkaerőegység 4,4 fö, ami alig több mint 1 föt jelent 100 hektáronként. A foglalkoztatottak valamennyien családtagok, akik számára nem jelentett problémát a modern eszközök alkalmazására való átállás.

Helyspecifikus gazdálkodással már 2004 óta foglalkoznak az üzemben. A 2014/2015-ös gazdálkodási évben a teljes terület több mint 60 százalékán, összesen 229 hektáron őszi káposztarepce, őszi árpa, őszi búza és egyéb szántóföldi növények termesztése során alkalmaztak precíziós technológiát. Legnagyobb területen, 90 hektáron öszi káposztarepcét termeltek helyspecifikusan. A növénytermesztés minden lépésénél, így vetés, tápanyag-utánpótlás, talajművelés, növényvédelem és betakarítás során is végeznek precíziós tevékenységet, melyhez saját tulajdonban lévő precíziós képességü erő-, vető-, betakarító- és szervestrágya-szóró gépeiket alkalmazzák. A közel 10 darab 
precíziós képességü gép mellett GPS-rendszert is üzemeltetnek, melyhez saját RTK-bázisállomással rendelkeznek.

A gazdaság vezetőjének szemléletére és ezáltal a gazdaság müködésére is általában jellemző az innovativitás. Ez a gyakorlatban megnyilvánul abban, hogy az üzem vetőmaggyártónak és gépgyártónak is referencia-, illetve bemutatógazdasága, valamint hogy a termelő maga is szívesen „kísérletezik" (pl. gabonavető géppel speciális homogenizált baromfitrágya kijuttatása, repce soronkénti vetése) a lehető legoptimálisabb termelési viszonyok elérése érdekében. Ez az újdonságokra való fogékonyság ösztönözte a precíziós technológia alkalmazását is, valamint a művelt terület és a táblák differenciáltsága, úgy a talajtípus, mint a domborzati viszonyok tekintetében.

A növénytermesztés során számos talajkímélő művelési elemet használnak: csökkentett menetszámú, illetve forgatás nélküli talajmüvelést, vetőkultivátoros és sávos vetést, direktvetést, bakhátas és mulcshagyó müvelést, altalajlazítást, illetve szükség esetén ezek kombinációját. A talajkímélő müvelés alkalmazását leginkább a talajnak mint erőforrásnak a hosszú távú megőrzése, fenntartása tette szükségessé, de szerepet játszott a nedvességtartalom megörzésének igénye is, mivel a területen az öntözési lehetőségek meglehetősen korlátozottak. Jellemző, hogy a mütrágyát igyekeznek természetes tápanyag-utánpótlással helyettesíteni, azonban ez a gazdaságban csak a nagyobb fajlagos termelési értékkel bíró növénykultúráknál térül meg. A szármaradványok miatt ugyan több növényvédő szerre van szükség, de még így is folyamatosan javul a talaj állapota, ami végső soron a stabilabb hozamokban mutatkozik meg. A mélyinterjús felmérésből az is kiderült, hogy mind a precíziós, mind pedig a talajkímélő technológia alkalmazásának sikere nagyban múlik azon, hogy a gazdálkodó birtokában van-e az azok alkalmazásához szükséges szakismereteknek.

A Zala megyei üzem Dél-Dunántúlon tevékenykedik. A társas vállalkozás átlagosan 1455 hektáron foglalkozott növénytermesztéssel 2010 és 2015 között, mely teljes egészében bérelt terület volt. Az első precíziós gazdálkodást is lehetővé tevő erőgépüket 2009-ben szerezték be, azonban ekkor még nem alkalmazták a technológiát. A következő években azonban egyre inkább elötérbe került a precíziós gazdálkodás, és 2011-től átálltak erre a müvelési módra. Ezt követően már csak olyan mezőgazdasági gépeket szereztek be, amelyek alkalmasak voltak a precíziós termelésre (keskeny sortávú vetőgép, széles sortávú vetőgép, mütrágyaszóró gépek, permetezőgépek). Az üzem ebböl a szempontból „túlgépesítettnek” tekinthető, de elsődleges szempont náluk a technológiai fegyelem, azaz a gazdálkodás során minden pontosan és időben történjen, technológiai akadály ne csökkentse a hatékonyságot.

A minél hatékonyabb gazdálkodás érdekében a területük 80 százalékán alkalmaztak és alkalmaznak jelenleg is precíziós talajminta-vételezést és talajtérképezést, a hozamtérképezés esetében ez az arány 100 százalék. A precíziós technológiával kukoricát, őszi árpát, őszi búzát, őszi káposztarepcét és szójababot termeltek, amelyeknél különböző mélységben alkalmazták a technológiát. A növénykultúrák közül kiemelkedett a kukorica termesztése, amelynél szinte minden munkafázisban ki- és felhasználták a precíziós technológia által biztosított előnyöket. A búza és a repce esetében leginkább a tápanyag-utánpótlás és a növényvédelem során alkalmazták a helyspecifikus gazdálkodás elemeit.

A Zala megyei üzem szemléletére is jellemző, hogy a precíziós technológia testreszabása, valamint az adott körülményeknek leginkább megfelelő „recept” érdekében szívesen „kísérleteznek”. Gyakran előfordul, hogy egy-egy táblán a talajmüvelést akár több alternatív eszközzel is el tudnák végezni, ilyenkor akár 2-3 változatot is kipróbálnak és az alapján határozzák meg, hogy melyiket alkalmazzák. A menedzsmentzónák szükségességéről a tábla mérete és heterogenitása alapján döntenek, homogén táblán nem differenciálnak. A megfelelő technológia kialakítása időigényes, például a napraforgónál 2-3 év is eltelt, mire bevezették a vetésszerkezetbe. A terméseredmények évröl évre történő folyamatos növekedése jól mutatja azt a folyamatot, ahogyan a technológia mind mélyebb elsajátítása megmutatkozik az eredményekben. 
A megfelelő képzettségü és minőségű munkaerő biztosításának problematikájával nem szembesült a vállalkozás. Alapvetően stabil munkaerö-állománnyal dolgoznak, akik nem feltétlen az agrárszakképzésből kerültek ki, hanem a cégnél szerezték meg a munkájukhoz szükséges ismereteket. Tapasztalataik szerint az alkalmazottak a kezdeti idegenkedés után többnyire jól fogadták és „,megszerették" a modern eszközöket, amelyek nagy könnyebbséget jelentenek a munkában.

A Somogy megyei mintaüzem a Dél-Dunántúlon folytatja gazdálkodását. A vizsgált időszakban - 2010 és 2015 között - átlagosan 309,7 hektáron folytattak növénytermesztést, mely terület teljes egészét bérlőként használtak. A gazdaságot 2003-ban alapították és a szükséges eszközöket, gépeket már ekkor beszerezték, az átgondolt jövőbeni céloknak megfelelően már ettől az évtől kezdődően alkalmaznak precíziós technológiát. Ekkor még csak egy sorvezető, kormányautomatika, fedélzeti számítógép és az ezeket kiegészítő berendezések jelentették a precíziós technológiát a vállalkozásnál. A kezdeti problémákat fokozatosan szüntették meg újabb eszközök és informatikai rendszerek beszerzésével. Az első években a permetezés során tudták kimagaslóan alkalmazni a technológia előnyeit. A magas színvonalú gépparkot 2-3 évente bővítették, s az újonnan beszerzett gépek szintén alkalmasak voltak a precíziós gazdálkodásban való alkalmazásra.

A hatékonyságot szem előtt tartva saját maguk állították össze kezdetektől fogva a precíziós talajminta-vételezést, a precíziós hozamtérképezést és a növényállapot-felvételezést. A tápanyagkijuttatási tervet külső cég készítette/készíti el számukra, így a kijuttatás szakmailag megalapozott és a korábbi „megszokáson alapuló döntések” minimálisra csökkent. A szolgáltatás igénybevétele magasabb költséget jelent, amelyet tovább növel az újonnan fejlesztett inputanyagok felhasználása is. A ráfordítások növekedését ellensúlyozta, hogy intenzívebbé vált a gazdálkodás és nőtt a hatékonyság. A mintaüzem 2007-ben jelentős fejlesztést hajtott végre, mivel a meglévő kormányautomatika-rendszert lecserélték hidraulikába épített robotpilótára, továbbá ettől az évtől GPS-rendszert üzemeltetnek és saját RTK-bázisállomással is rendelkeznek, illetve a kezelőfelületet is újabbra cserélték. A fejlesztések elősegítették a további fejlesztéseket és beruházásokat is. A beruházás eredményeképpen jelentősen csökkent a permetezés vegyszerköltsége, valamint megtakarítás képződött a vetőmag-felhasználás során is.

Helyspecifikus technológiával alapvetően őszi búzát, őszi árpát, őszi káposztarepcét, napraforgót és cukorrépát termesztenek (a vetésforgótól függően átlagosan 7-9 növénykultúrát termelnek precíziós tecnológiával). Mindegyik növény esetében már 2005 óta precíziós gazdálkodást folytatnak és kivétel nélkül a termelés minden fázisában jelen van ez a technológia. A mintaüzem tudatos hozzáállását tükrözi, hogy középpontban áll esetükben a fenntarthatóság, melyet a tápanyag kijuttatásakor, a növényvédelem során és a teljes termelési fázisban szem elött tartanak. Ez a tudatosság magasabb költséggel is jár, de kimutatható többlethozamot is generált az elmúlt időszakban. A költségeiket csökkenti, hogy vetömag-előállítással is foglalkoznak.

A mintaüzem véleménye szerint a mezőgazdaság jövőbeni fejlődésének és fejlesztésének egyik mérföldköve a precíziós technológia alkalmazásának térnyerése. Ebben nagy szerepük lehet az integrátoroknak, akiknek viszont az inputanyag felhasználásának csökkenése miatt jelenleg nem minden esetben állhat érdekükben a teljes elterjedés elösegítése. Támogathatná a jövőbeni alkalmazás növelését, ha a fejlesztési forrásokat célzottabban határoznák meg, illetve ha az agrár-környezetgazdálkodási programban kiemelt szerepet kapna a technológia alkalmazása. Az elterjedést az is akadályozza, hogy a jó minőségű mezőgazdasági területen gazdálkodók nem érdekeltek a precíziós technológia terjesztésében és alkalmazásában, hiszen anélkül is jó hozamokat képesek elérni. 


\subsection{A mintaüzemek és a kontrollcsoportok összehasonlítása}

A precíziós és helyspecifikus gazdálkodást végző mintaüzemek és a hagyományosan gazdálkodó üzemek összehasonlítása során az alábbi területekre fókuszáltunk:

- átlagos terményhozam (6 év);

- közvetlen költségek;

- termelési érték és

- ágazati eredmény.

Mind a négy dimenziónál megvizsgáltuk, hogy kimutatható-e eltérés a mintaüzemek és a kontrollcsoport között. Ezek figyelembevételével alakítottuk ki az egyes mintaüzemhez tartozó kontrollcsoportot. ${ }^{1}$

\subsection{1. Átlagos hozam és termelési érték alakulása}

Az átlagos hozam a vetésterületre vetített megtermelt mennyiséget jelenti. Kutatásunk során azon főbb mezőgazdasági növényeket vettük figyelembe, melyeknél a mintaüzemek precíziós gazdálkodást folytattak vagy folytatnak. A kiemelt mezőgazdasági növények a következők voltak:

- őszi búza;

- kukorica;

- napraforgó;

- őszi káposztarepce és

- cukorrépa.

Az egyes növények termesztése időben mintaüzemenként eltérő volt: vagy egyáltalán nem termelték az adott kultúrát, vagy a vetésforgó miatt az adott évben nem került vetésre. Az alfejezetben csak a búza és a kukorica átlagos hozamának alakulását mutatjuk be, mivel e két növényt mindhárom mintaüzem majdnem a teljes vizsgált időszakban termesztette. ${ }^{2}$

\section{7. ábra: A búza átlaghozamának alakulása a mintaüzemekben, 2010-2015}

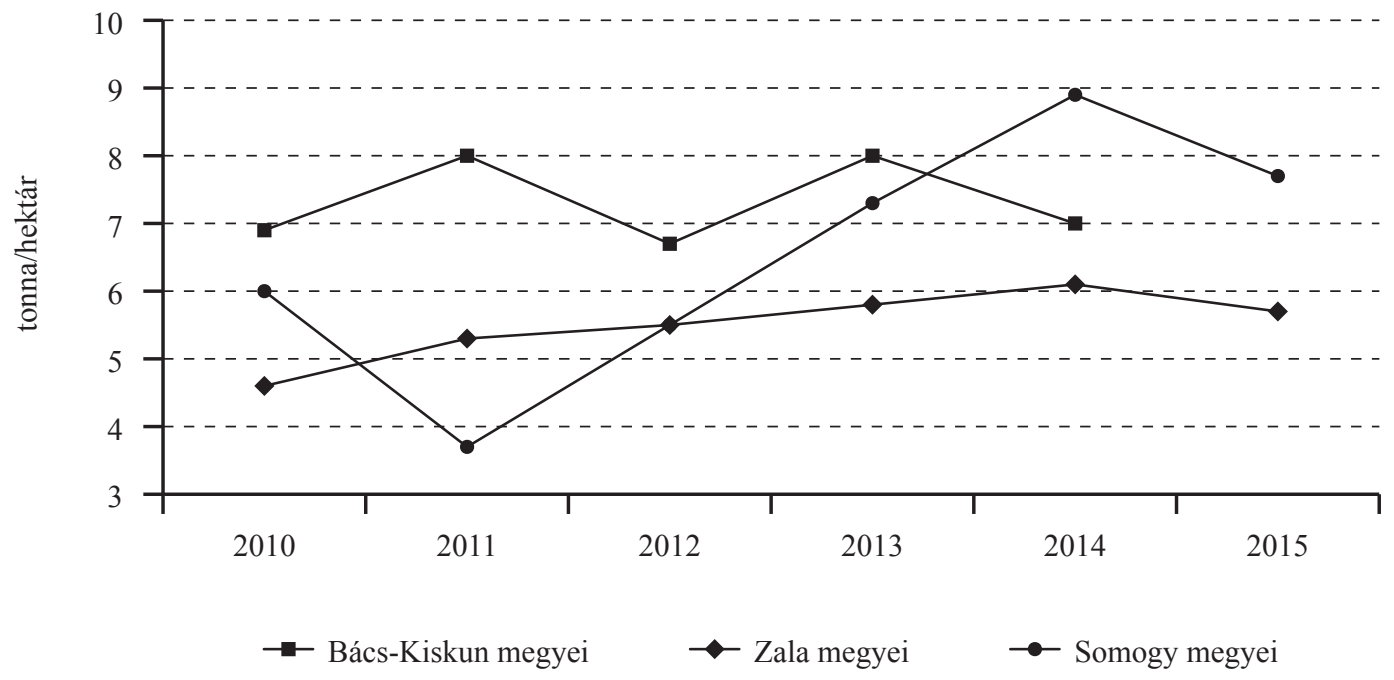

Forrás: AKI Horizontális Elemzési Osztály

A kapcsolódó módszertani leírások a 4. fejezetben találhatók.

A napraforgó, repce és cukorrépa átlaghozamának üzemenkénti alakulását bemutató ábrák az 3., 4. és 5. számú mellékletben találhatók. 
A mintaüzemek nem mutattak egységes képet a búza esetében. A Bács-Kiskun megyei mintaüzem átlaghozama igen hektikusan változott a vizsgált időszakban, de az még így is jelentősen meghaladta mind a Zala megyei, mind a Somogy megyei üzem hasonló értékeit. A Bács-Kiskun megyei termelő 2015-ben nem vetett búzát. A Zalai megyei mintaüzem átlagos búzatermés-eredménye folyamatos és egyenletes növekedést mutatott a vizsgált hat évben. Ennek oka, hogy a cég a mezőgazdasági gépparkját folyamatosan fejlesztette, illetve megfelelő szakismeretek birtokában alkalmazta a precíziós technológiát a tápanyag-utánpótlás, a növényvédelem és a betakarítás során. A Somogy megyei precíziós technológiát alkalmazó mintaüzem a búzatermesztés terén az előző két üzemmel szemben dinamikus és eröteljes hozamnövekedést tudott produkálni. A búza átlaghozama 2014-ben 8,9 tonna/ hektár volt, melyet az adott évben a másik két üzem meg sem tudott közelíteni. Ebben az évben 40 hektáron termeltek búzát, amely jelentősen elmaradt a másik két üzem vetésterületétől, tehát hozzájuk képest a Somogy megyei üzem koncentráltabban termelt búzát. A növekedés azonban nem folytatódott tovább, a másik két üzemhez hasonlóan az átlaghozam 2015-ben több mint 1 tonnával esett vissza hektáronként (0).

A kukoricánál a Zala megyei mintaüzem a búzatermesztéshez hasonlóan szintén stabil növekedést mutatott a vizsgált időszakban. Az átlagos hozam 2014-ben 10,7 tonna/hektár volt, amelyet csak a Bács-Kiskun megyei üzem termésátlaga múlt felül. A Bács-Kiskun és a Somogy megyei mintaüzem termésátlaga változóan alakult a vizsgált időszakban. Ennek oka - kiváltképpen a Somogy megyei üzemnél, de a Bács-Kiskun megyeinél is a vizsgált időszak első négy évében -, hogy a kukoricát a cukorrépa után vetették. A cukorrépa egy igényes szántóföldi kultúra, a talajban lévő - számára szükséges - nitrogénmennyiséget leköti, így az elvetett kukorica csak jelentős mütrágya-felhasználás mellett képes a kívánt hozamot biztosítani. Továbbá az időjárási viszonyok is jelentősen befolyásolták a kukorica hozamát (18. ábra).

\section{8. ábra: A kukorica átlaghozamának alakulása a mintaüzemekben, 2010-2015}

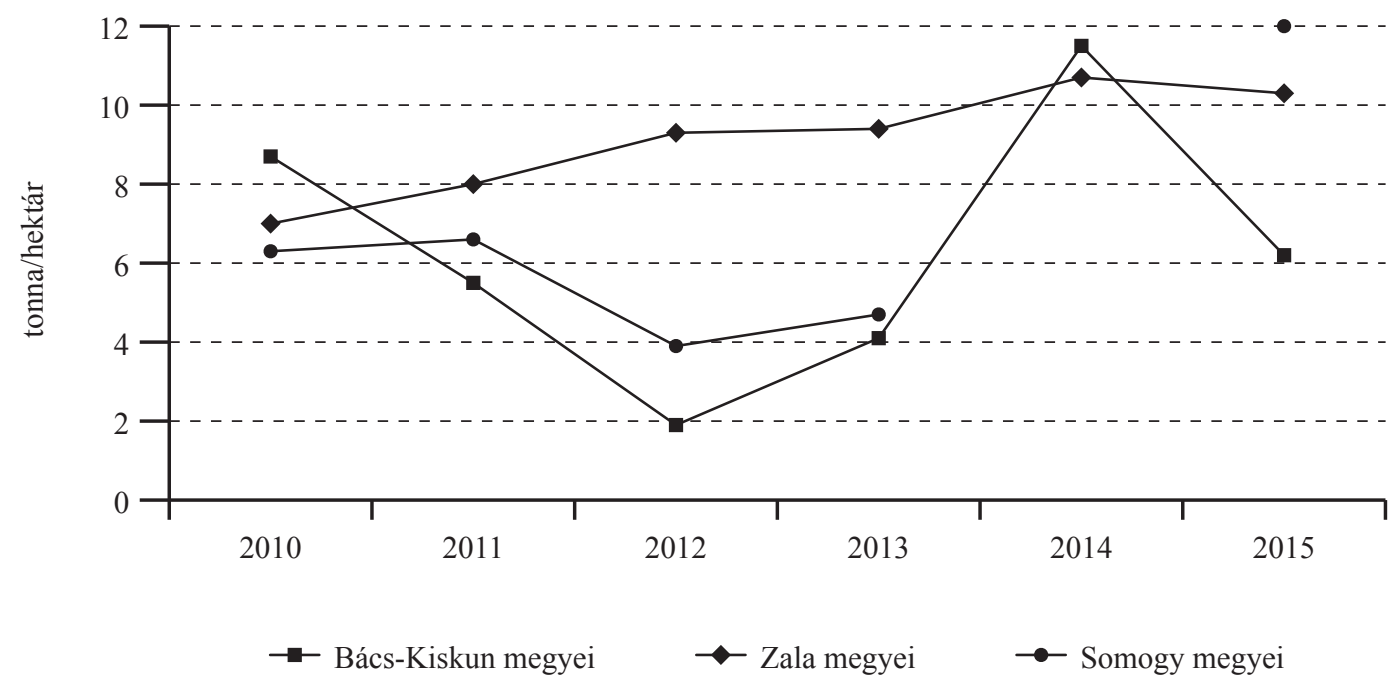

Forrás: AKI Horizontális Elemzési Osztály

Ha a mintaüzemek teljesítményét a kontrollcsoportba került üzemekhez hasonlítjuk, akkor megállapítható, hogy magasabb átlaghozamot értek el a mintaüzemek a legtöbb növénykultúra esetében. Ez alól kivételt csak a Bács-Kiskun megyei üzem kukorica-termésátlaga, valamint a Somogy megyei üzem napraforgó- és cukorrépa-termésátlaga képez (19. ábra). 
19. ábra: A mintaüzemek átlaghozamának nagysága a kontrollcsoporthoz viszonyítva, 2010-2015

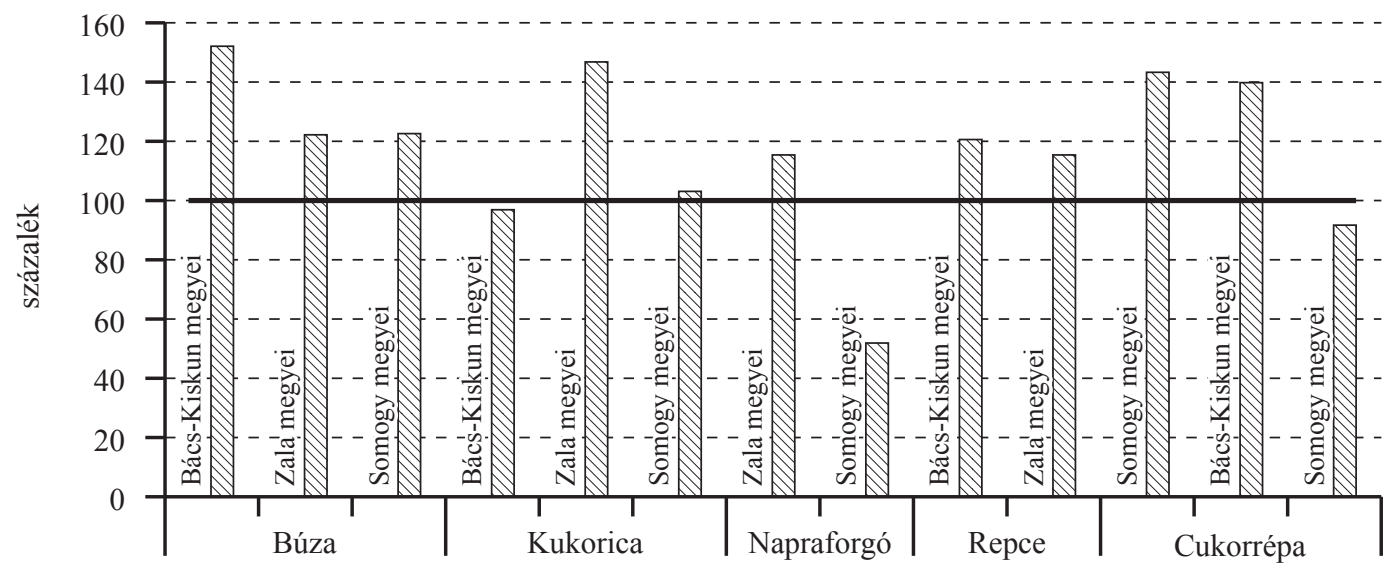

Eltérés - mintaüzem/kontroll (százalék)

Mintaüzem

Forrás: AKI Horizontális Elemzési Osztály

A búza esetében mindhárom mintaüzem átlaghozama meghaladta a kontrollcsoport által elért átlaghozamot. A legjelentősebb előnnyel a Bács-Kiskun megyei üzem rendelkezett, amely 52,1 százalékkal magasabb átlaghozamot ért el. Ehhez jelentősen hozzájárult, hogy a mintaüzem a búza esetében már 2004 óta folytat precíziós gazdálkodást. A Somogy és a Zala megyei mintaüzemek átlaghozama közel azonos mértékben haladta meg a saját kontrollcsoport átlaghozamának értékét (+22,2, illetve $+22,6$ százalékkal). A Zala megyei mintaüzem a búzatermesztés terén 2011 óta folytat precíziós gazdálkodást, míg a Somogy megyei üzem 2005-től müveli precíziós technológia alkalmazásával a búzával bevetett területet.

A kukorica átlaghozamának alakulása kissé vegyesebb képet mutat az egyes üzemeknél. Kitünik a Zala megyei mintaüzem által elért 46,8 százalékos többlethozam. A legutolsó lezárt gazdálkodási évben több mint 350 hektáron termeltek kukoricát, illetve e növény esetében is 2011 óta alkalmaznak precíziós technológiát. A Somogy megyei üzem által produkált átlaghozam „csupán” 3,1 százalékkal volt magasabb, mint a kontrollcsoport átlaghozama. A Bács-Kiskun megyei mintaüzem esetében az előző két üzemmel ellentétben az átlaghozam 3,1 százalékkal maradt el a kontrollcsoport értékétől. Ennek fő oka, hogy a Somogy megyei üzemhez hasonlóan a korábbi években a cukorrépát követte a kukorica a vetésforgóban, a rosszabb évek így jelentősen „lehúzták” az elért átlaghozam értékét a vizsgált években.

Napraforgó termesztésével a Somogy és a Zala megyei üzem foglalkozott. A Zala megyei üzem átlaghozama 15,4 százalékkal volt magasabb, mint a kontrollcsoporté, a Somogy megyei üzem termésátlaga pedig jelentősen - 48,1 százalékkal - elmaradt a nem precíziós gazdálkodást folytató üzemek értékétől, aminek oka, hogy a Somogy megyei mintaüzem alapvetően napraforgó-vetőmag termesztésével foglalkozott.

A repce esetében a búzához hasonlóan mindhárom mintaüzem átlaghozama meghaladta a kontrollcsoportok által elért értéket. A Somogy megyei üzem átlaghozama 43,3 százalékkal volt magasabb - több mint 10 éve precíziós technológiával mủvelik a repcével bevetett területüket, illetve az utolsó gazdálkodási évben több mint 50 hektáron termeltek repcét -, a Bács-Kiskun megyei mintaüzem hozama 20,6 százalékkal, míg a Zala megyeié 15,4 százalékkal volt több, mint a hozzájuk tartozó kontrollcsoport átlaghozamának értéke. 
A Bács-Kiskun megyei üzem jelentős (39,8 százalékos) többlethozamot ért el a cukorrépa termesztése terén, míg a Somogy megyei mintaüzem átlaghozama 8,3 százalékkal maradt el a kontrollcsoport értékétől.

A termelési érték néhány kivételtől eltekintve minden növénykultúra esetében a mintaüzemeknél volt magasabb. A búzánál a Somogy megyei üzem értéke maradt el a kontrollcsoportétól 11,4 százalékkal, miközben a Bács-Kiskun megyei precíziós gazdálkodást folytató mintaüzemnél 75,1 százalékkal meghaladta azt. A kukorica termelési értéke a Zala megyei üzemben 45,8 százalékkal magasabb értéket ért el, mint a kontrollcsoport üzemei, a Bács-Kiskun megyei mintaüzem viszont 7 százalékos elmaradást mutatott (19. ábra).

A napraforgó-termesztésben mind a Zala megyei, mind a Somogy megyei üzem jelentős többletet mutatott a termelési értéket illetően.

A Somogy megyei üzem a búzához hasonlóan a repcetermesztésben 9,3 százalékkal maradt el a kontrollcsoport termelési értékétől, míg a másik két üzem többletet mutatott.

A cukorrépánál a két mintaüzem 32,1 százalékos, illetve 4,1 százalékos többlet termelési értéket ért el.

20. ábra: A termelési értékek eltérése a mintaüzemek és a kontrollcsoportok esetében

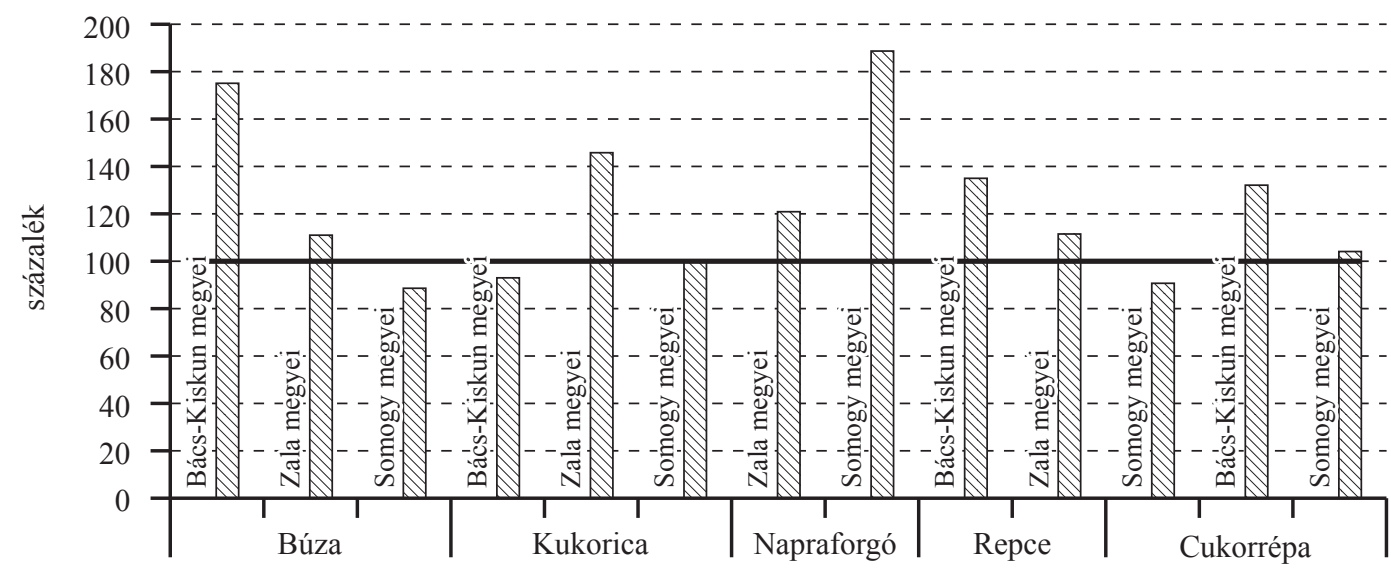

Eltérés - mintaüzem/kontroll (százalék)

— Mintaüzem

Forrás: AKI Horizontális Elemzési Osztály

\subsubsection{Költségek alakulása}

A precíziós gazdálkodást folytató három mintaüzemnél a vizsgált időszakban a fajlagos termelési költség nagysága - abban az esetben, ha a költségeket a vetésterület nagyságára vetítettük - kivétel nélkül magasabb volt, mint a kontrollcsoportoknál kimutatott érték (20. ábra). Ennek legfőbb oka, hogy a precíziós és helyspecifikus gazdálkodást végző mintaüzemeknél a technológia alkalmazása általában nagyobb költséggel jár. Ez természetesen függ attól is, hogy a technológiát milyen régóta alkalmazzák (megszerzett tapasztalatok), továbbá a vetésforgótól, az időjárási jellemzőktől, a kijuttatott növényvédő szerek, mütrágya szükséges és megtervezett mennyiségétől stb. A költségek áttekintése során az alábbi költségkategóriákat vettük figyelembe:

- vetömag, szaporítóanyag költsége,

- mütrágyaköltség, 
- növényvédőszer-költség,

- gépköltség, illetve

- összes termelési költség.

Külön kiemelendő, hogy a repce termesztésénél a vetőmagköltség mindhárom üzemben jelentősen alacsonyabb volt, mint a kontrollcsoport esetében. A búzánál a Bács-Kiskun megyei üzem a harmadát fizette a vetőmagért, míg a Somogy megyei mintaüzem 1,8 százalékkal kedvezőbb vetőmagköltséggel számolhatott, mint a kontrollcsoportba került üzemek. A kukoricánál, a napraforgónál és a cukorrépánál átlagosan 5-15 százalékkal volt magasabb a mintaüzemek vetőmagköltsége - kivéve a Somogy megyei üzemet a napraforgó, illetve a Bács-Kiskun megyei üzemet a cukorrépa esetében.

A mütrágyaköltség mindhárom üzemnél jelentős többletet mutatott a kontrollcsoporthoz viszonyítva. Ez nem kirívó eltérés, hiszen jobb és kedvezőbb hozamot csak úgy lehet elérni, ha a tápanyag-utánpótlás célzott és átgondolt kijuttatási terv alapján történik. Magyarországon nemzetközi összehasonlításban jellemzően alacsony a mütrágya-felhasználás, így a precíziós technológia bevezetése a mütrágya-felhasználás növekedését is többnyire maga után vonja. Az eltérés az öt növényt figyelembe véve 70 és 170 százalék között szóródott.

A növényvédőszer-költségek eltérése a mütrágya-felhasználáshoz hasonlóan alakult, habár ebben az esetben az eltérés nagysága már mérsékeltebb volt, a különbség 20 és 135 százalék között szóródott. Kivételt képezett a kukoricánál a Zala megyei és a Somogy megyei üzem, esetükben a kijuttatott növényvédő szer költsége 0,3 , illetve 24,2 százalékkal volt alacsonyabb, mint a kontrollcsoport ugyanezen értéke.

A gépköltség alakulása sokkal heterogénebb volt a három üzemnél. A Somogy megyei és a Zala megyei üzem gépköltsége a búza, a kukorica és a repce esetében is alacsonyabb volt, mint a kontrollcsoporté. A Bács-Kiskun megyei üzem gépköltsége mind az öt növénykultúránál meghaladta a kontrollcsoport gépköltségének értékét.

\section{1. ábra: Hektárra vetített termelési költség alakulása}

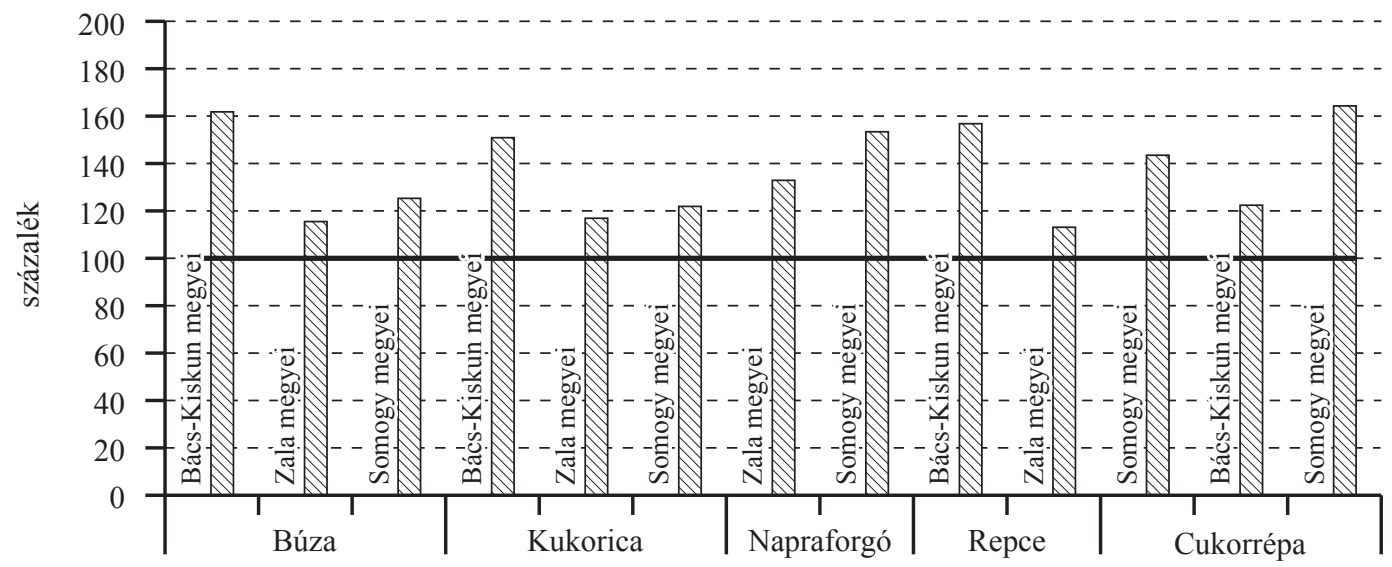

MUV Eltérés - mintaüzem/kontroll (százalék)

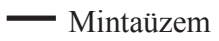

Forrás: AKI Horizontális Elemzési Osztály

Amennyiben a termelési költséget a megtermelt növény mennyiségére (tonna) vetítettük, differenciáltabb eredményt kaptunk, mint az előzőekben. A búza termesztése során csupán a somogyi mintaüzem termelési költsége haladta meg a kontrollcsoport értékét 2,9 százalékkal, a másik két 
üzem termelési költsége kedvezőbb volt az összehasonlításba bevont üzemekénél. A kukoricánál a zalai üzem termelési költsége 27,1 százalékkal kedvezőbb volt, mint a nem precíziós gazdálkodást folytató üzemeké. Jelentős eltérést mutatott a somogyi üzem a napraforgóhoz kapcsolódó termelési költségnél, de ahogy korábban is jeleztük, az egyik fő oka a jelentős többletnek, hogy a mintaüzem napraforgó-vetőmagot termesztett. A termelési költség eltérése a kontrollcsoporthoz viszonyítva a repcénél volt a legkiegyensúlyozottabb, az értékek 30 százalékos értékközben szóródtak (22. ábra).

\section{2. ábra: Termelési költség alakulása tonnánként}

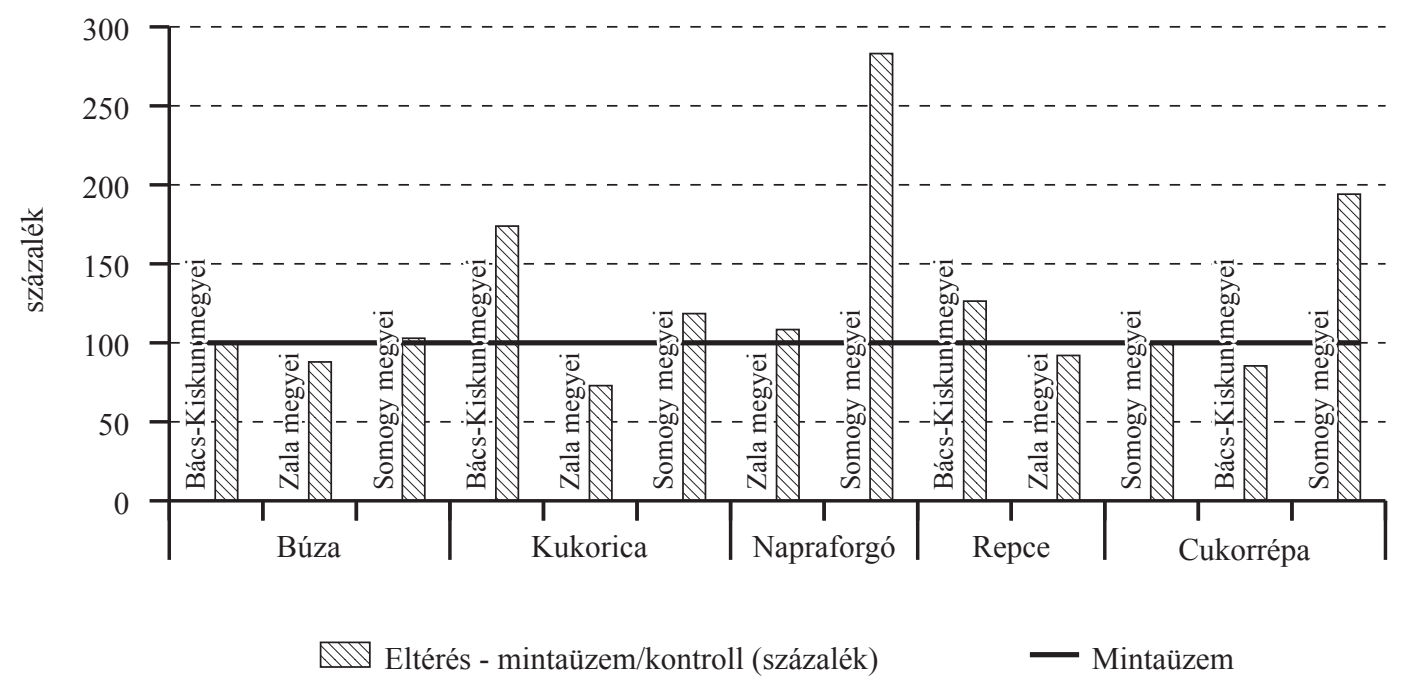

Forrás: AKI Horizontális Elemzési Osztály

A termelési költségen belül a vetőmag költségének eltérése volt a legkedvezőbb a mintaüzemek oldaláról nézve. A Bács-Kiskun megyei üzem kukoricavetőmag-költsége 25,6 százalékkal haladta meg a kontrollcsoport értékét, ami az egyik legmagasabb volt az összes növénykultúrát és az összes mintaüzemet alapul véve.

A mütrágya-felhasználás költsége tekintetében egységes képet mutattak a mintaüzemek, ugyanúgy, mint a vetésterületre (hektár) vetített költségek esetében, mivel minden növénykultúránál a mintaüzemek költsége volt a magasabb: az értékek 20 és 265 százalék között szóródtak. A búzánál a Bács-Kiskun megyei üzem értéke volt a legkedvezőbb +19,9 százalékkal, kukoricánál a zalai üzemé +26,6 százalékkal, a repcénél a három üzem értéke pedig +50-90 százalék között ingadozott. Itt is a korábban megfogalmazott indokok okozták a jelentős eltérést, miszerint jelentősebb hozamot koncentráltabb tápanyag-utánpótlással lehet elérni.

A növényvédő szer költsége szintén a legtöbb esetben a nem precíziós gazdálkodást folytató üzemeknél volt a kedvezőbb. A Zala megyei üzem ezen költsége búza esetében 1,6 százalékkal volt kedvezőbb, míg a kukoricánál már 34,4 százalékkal. Hasonló kedvező értéket ért el a somogyi mintaüzem a kukoricánál, ahol 27,7 százalékkal volt alacsonyabb a növényvédőszer-költség a kontrollcsoporthoz viszonyítva.

A vetésterületre vetített gépköltség értéke a búza esetében mindhárom mintaüzemnél 20-35 százalékkal kedvezőbb volt, mint a nem precíziós gazdálkodást folytatóknál. Ezt az előnyt a zalai és a somogyi üzem megtartotta a kukorica esetében 44,4, illetve 22,6 százalékkal. A Bács-Kiskun megyei üzem már 47,8 százalékos többletköltséggel bírt. A napraforgó termesztésénél a Zala megyei üzem 21,6 százalékkal alacsonyabb gépköltséget számolt el, míg a somogyi üzem 130,6 százalékkal többet, mint a kontrollcsoportba tartozó üzemek. Repce esetében a kukoricánál tapasztalt eltéréseket 
mutattunk ki a három üzemnél. Míg a Bács-Kiskun megyei üzem gépköltsége 2,1 százalékkal magasabb volt, addig a zalai üzemé 32,4 százalékkal, a somogyi üzemé pedig 49,5 százalékkal volt alacsonyabb a kontrollcsoporthoz viszonyítva. A cukorrépánál mind a Bács-Kiskun megyei, mind a Somogy megyei üzem gépköltsége magasabb volt 5,4, illetve 25,5 százalékkal.

\subsubsection{Jövedelem és jövedelmezőség alakulása}

A precíziós és nem precíziós gazdálkodást folytató üzemeknél a jövedelmet az egy hektárra vetített ágazati eredmény alapján határoztuk meg, amely a termelési érték és az összes költség különbözete egy hektárra vetítve.

A mintaüzemek jövedelme az egyes növénykultúráknál eltérő módon alakult a vizsgált időszakban a kontrollcsoporthoz viszonyítva. Ebben jelentős szerepet játszott a megtermelt termék mennyisége és értékesítési ára, illetve a termeléshez kapcsolódó felmerült költségek aránya is.

A Bács-Kiskun megyei üzem jövedelme a búza- és a cukorrépa-termelésben volt igen kedvező, 146,8, illetve 53,6 százalékkal haladta meg a nem precíziós gazdálkodást folytató üzemek hasonló értékeit. A kukorica termesztésénél negatív eredményt ért el a mintaüzem, ami más üzemekre nem volt jellemző egyik növénykultúra esetében sem. A repcénél 25,6 százalékkal maradt el a kontrollcsoport értékétől, köszönhetően annak, hogy költségeik több mint 50 százalékkal voltak magasabbak (23. ábra).

A Zala megyei mintaüzem a kukoricánál és a repcénél ért el többletjövedelmet a nem precíziós gazdálkodást folytató üzemekhez viszonyítva: a kukorica esetében több mint 2,5-szeres eredményt realizáltak. A búza és a napraforgó mérsékeltebb jövedelmet eredményezett, azok 8,1, illetve 15,4 százalékkal maradtak el a kontrollcsoporttól.

A Somogy megyei mintaüzem jövedelemtermelő képessége kiváló volt a búza, a napraforgó és a repce esetében is, a napraforgónál elért jövedelmük közel háromszorosa volt a kontrollcsoporténak. A kukoricánál a megtermelt jövedelem hektáronként 52,1 százalékkal volt alacsonyabb, mint a nem precíziós gazdálkodást folytató üzemeknél.

\section{3. ábra: Az ágazati eredmény eltérése a mintaüzemek és a kontrollcsoportok esetében}

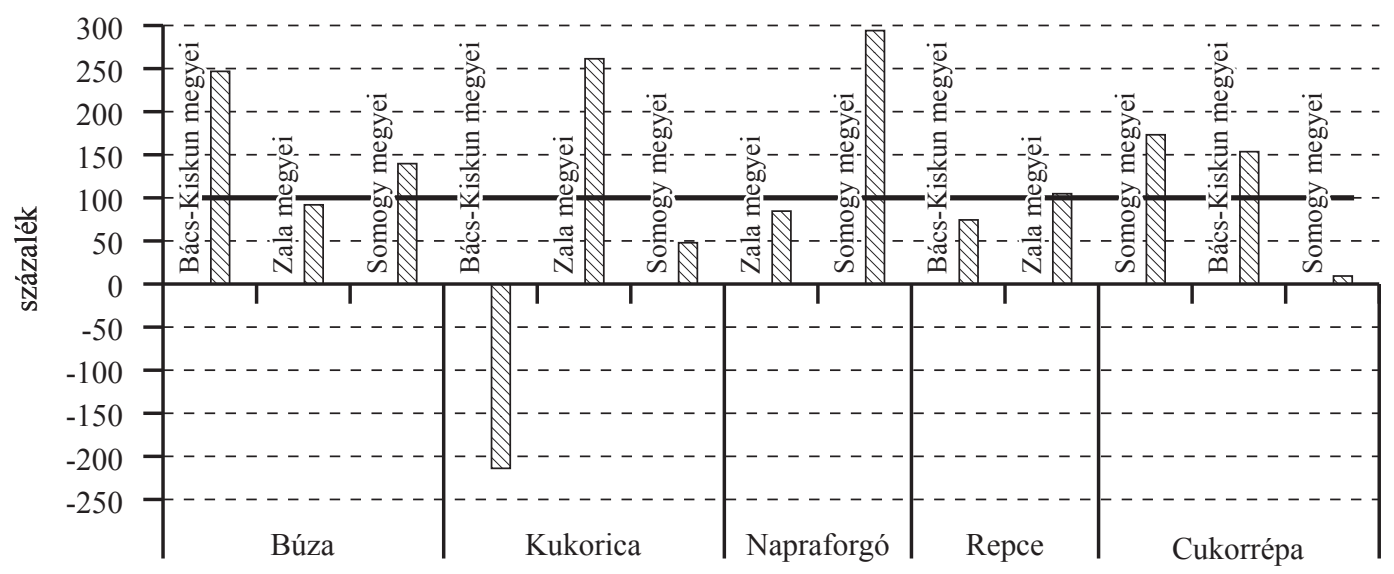


A mintaüzemek és a kontrollcsoport jövedelmezőségét összehasonlítottuk a költségarányos jövedelem vizsgálatával is, melynek során megvizsgáltuk, hogy az egyes üzemek egységnyi költségráfordítással mekkora jövedelmet értek el. Az eredményeink növénykultúránként és kultúrán belül is igen széles értékközben szóródtak (6. táblázat).

A Bács-Kiskun megyei mintaüzemnél a búza költségarányos jövedelme kedvezőbb volt a másik két mintaüzemnél és az egyes kontrollcsoportoknál is. Az elért 28,5 százalékos érték a magas értékesítési árakon keresztül realizált nagy árbevételnek is köszönhető. A három mintaüzem közül csak a Zala megyei üzem jövedelmezősége volt alacsonyabb (18,5 százalék), mint a kontrollcsoport által realizált érték (24,1 százalék).

A kukoricánál a Bács-Kiskun megyei mintaüzem elveszítette a búzánál kimutatott jelentős előnyét és a vizsgált időszakban a költségarányos jövedelme -28,3 százalék volt, szemben a kontrollcsoport 19,0 százalékos értékével. Ennek alapvető okát az előző alfejezetben már bemutattuk. Kiemelkedő jövedelmezőséget ért el a Zala megyei mintaüzem. A 9,1 tonna/hektáros kukoricatermésnek köszönhetően egységnyi költséggel 57,5 százalékos jövedelmet ért el a mintaüzem, ami több mint kétszerese volt a kontrollcsoportba tartozó üzemek átlagos értékének. A Somogy megyei mintaüzem a Bács-Kiskun megyeihez hasonlóan kedvezőtlenebb jövedelmezőséget ért el a kontrollcsoporthoz képest, de esetében még pozitív volt a mutató értéke.

\section{6. táblázat: A költségarányos jövedelem a mintaüzemeknél és a kontrollcsoportnál}

százalék

\begin{tabular}{llrr}
\hline \multirow{2}{*}{ Növénykultúra } & \multicolumn{1}{c}{ Mintaüzem } & Költségarányos jövedelem átlagos értéke \\
\cline { 2 - 4 } Búza & Bács-Kiskun megyei & mintaüzem & kontrollcsoport \\
\cline { 2 - 4 } & Zala megyei & 28,5 & 18,2 \\
\cline { 2 - 4 } & Somogy megyei & 18,5 & 24,1 \\
\hline \multirow{3}{*}{ Kukorica } & Bács-Kiskun megyei & 24,9 & 24,6 \\
\cline { 2 - 4 } & Zala megyei & $-28,3$ & 19,0 \\
\cline { 2 - 4 } Napraforgó & Somogy megyei & 57,5 & 27,2 \\
\hline \multirow{3}{*}{ Repce } & Zala megyei & 17,6 & 43,0 \\
\cline { 2 - 4 } & Somogy megyei & 20,8 & 35,3 \\
\hline \multirow{2}{*}{ Cukorrépa } & Bács-Kiskun megyei & 69,0 & 33,3 \\
\cline { 2 - 4 } & Zala megyei & 15,2 & 33,7 \\
\cline { 2 - 4 } & Somogy megyei & 23,1 & 26,5 \\
\hline
\end{tabular}

Forrás: AKI Horizontális Elemzési Osztály

A somogyi mintaüzem a napraforgó termesztése során érte el a legkiemelkedőbb költségarányos jövedelmet, a 69,0 százalékos eredményt sem a zalai mintaüzem, sem a kontrollcsoport nem tudta megközelíteni. Az öt növénykultúra tekintetében is ez volt a legkiemelkedőbb jövedelmezőségi érték.

A repcénél mindhárom mintaüzem pozitív jövedelmezöséget ért el, ugyanakkor egyedül a Somogy megyei üzem jövedelmezösége volt magasabb, mint a kontrollcsoport átlagos értéke.

A cukorrépa termesztése során a Bács-Kiskun megyei üzem 58,0 százalékos jövedelmezőséget ért el, ami 1,3-szorosa volt a kontrollcsoport átlagos jövedelmezőségének. A Somogy megyei üzem 3,5 százalékos jövedelmezősége töredéke volt a kontrollcsoport 67,3 százalékos értékének. 



\section{A precíziós és talajkímélő gazdálkodást folytató termelők körében végzett statisztikai vizsgálatok}

A fejezet a módszertani részben már ismertetett statisztikai vizsgálatok eredményeit mutatja be összesen négyféle változatban. Az egyes változatoknál a bevételt képező tételek közül a hozamok, a termelési érték, illetve az ágazat összes bevétele, míg a költségek közül az inputanyagköltségek - vetőmagköltség, növényvédőszer-költség, mütrágyaköltség, gépköltség és ebből traktorok költsége -, a fötermék termesztésének önköltsége, illetve a termelési költség került elemzésre, míg az eredménykategóriáknál a fedezeti hozzájárulás és az ágazati eredmény. A második alfejezetben azon számítási eredményeket, amelyek a legpontosabban szemléltetik a precíziós gazdálkodás üzemre gyakorolt hatását, statisztikai elemzéssel is igazoltuk.

\subsection{A precíziós technológia gazdasági hatásainak kimutatása a 45 üzem körében, a kontrollcsoport adataihoz viszonyítva}

Az első változatban a vállalkozások által precíziósan termesztett növénykultúrák 2015. évi ágazati költség- és jövedelemadatai képezték a vizsgálat tárgyát. A precíziós üzemek teljesítményét a hagyományos üzemekével vetettük össze úgy, hogy a kontrollcsoport kiválasztása kizárólag gazdasági forma (egyéni és társas) alapján történt.

Az eredmények a különböző növénykultúráknál számottevő eltérést mutattak a vetésterületnél. A precíziós üzemek átlagosan a kukoricánál több mint háromszoros, a repcénél 2,4-szeres, a napraforgónál közel kétszeres vetésterülettel bírtak a kontrollcsoporthoz képest, de a búzánál is magasabbnak bizonyult 51 százalékkal. Az öszi árpa vetésterülete mindössze 12 százalékos eltérést mutatott. A gazdaságok termőterületének minőségét meghatározó aranykorona-értékben nem volt számottevő az eltérés, a precíziós üzemek körében átlagosan maximum 10 százalékkal volt jobb minőségü a talaj, mint amelyen a kontrollcsoportban szereplö üzemek gazdálkodtak, azaz a talaj termőképességéből származó egyenlőtlenségek hatásával nem kellett számolnunk.

A precíziós gazdálkodás hozamai minden egyes növénykultúrában felülmúlták a kontrollcsoport által realizált értéket. A búzatermesztésben 7, a kukoricánál 9, a napraforgónál 10, az őszi káposztarepcénél 11, az őszi árpánál pedig 5 százalékkal takarítottak be nagyobb mennyiséget egy hektárról a precíziós termelök (7. táblázat). A hozamokhoz hasonlóan a termelési érték is nagyobb volumenü volt a helyspecifikus gazdálkodóknál, búza, kukorica, napraforgó, repce és őszi árpa esetében rendre 13, 16, 11, 24 és 13 százalékkal. Ennek eredményeképpen az ágazat átlagos összes bevétele a precíziós üzemekben a búza és a repce kivételével meghaladta a hagyományos gazdaságokét, kukoricánál 13, őszi árpánál 25, napraforgónál pedig 50 (!) százalékkal. Az őszi káposztarepce termesztése során a precíziós gazdaságok által realizált összes bevétel megegyezett a kontrollcsoportéval, a búzánál mindössze 3 százalékkal múlta alul azt. Az inputanyagköltségek közül a vetömagköltség a búza és a repce esetében elmaradt a kontrollcsoportétól előbbinél 14, utóbbinál pedig 3 százalékkal, míg a kukoricánál és a napraforgónál kedvezőtlenül alakult, 12, illetve 8 százalékkal meghaladta azt. A felhasznált mütrágya mennyisége és költsége egyaránt magasabb volt a precíziós gazdaságokban, viszont itt érdemes megemlíteni - amire már a szakirodalomban is találtunk példát -, hogy a technológia nem feltétlenül hordozza magában a termelési költségek csökkenését, sokkal inkább eredményezi a hatékonyság növekedését. Mütrágyára a precíziós árpatermesztők 23 százalékkal, a búza- és repcetermesztő üzemek közel 30 százalékkal, a kukoricatermesztők pedig 41 százalékkal fordítottak többet a hagyományos üzemeknél. Csökkenés egyedül a napraforgónál volt kimutatható, amely 9 százalékkal volt alacsonyabb a kontrollcsoportot jellemző értéknél. A növényvédő szer költsége szintén meghaladta a hagyományos termesztéstechnológiát alkalmazókét, az eltérés mértéke 8 és 56 százalék között változott. Kiugróan magas értéket (56 és 37 százalékkal) a kukorica és a repce ese- 
tében tapasztaltunk. Itt fontos hangsúlyozni, hogy - amint már a kérdőív kiértékelésénél is említésre került - a felmérésben részt vevő precíziós gazdaságok zöme talajkímélő müvelést is folytat, amely sok esetben vezet a növényvédő szer mennyiségének növekedéséhez a termőtalajban felszaporodott gyomnövények és kórokozók miatt.

\section{7. táblázat: A vizsgált ágazatok főbb mutatóinak eltérése a precíziós technológia alkalmazásának hatására a 45 üzemnél}

\begin{tabular}{|c|c|c|c|c|c|}
\hline Ágazati mutatók & Búza & Kukorica & Napraforgó & $\begin{array}{c}\text { Őszi } \\
\text { káposzta- } \\
\text { repce }\end{array}$ & Őszi árpa \\
\hline Hozam & +7 & +9 & +10 & +11 & +5 \\
\hline Termelési érték & +13 & +16 & +11 & +24 & +13 \\
\hline Ágazat összes bevétele & -3 & +13 & +50 & 0 & +25 \\
\hline \multicolumn{6}{|l|}{ Inputanyagköltségek } \\
\hline vetömagköltség & -14 & +12 & +8 & -3 & +14 \\
\hline mütrágyaköltség & +29 & +41 & -9 & +31 & +23 \\
\hline növényvédőszer-költség & +10 & +56 & +25 & +37 & +8 \\
\hline Gépköltség & +2 & -14 & -11 & 0 & -13 \\
\hline \multicolumn{6}{|l|}{ ebböl: } \\
\hline traktorok költsége & -4 & -25 & -15 & -3 & -22 \\
\hline Termelési költség & +9 & +23 & +3 & +19 & +9 \\
\hline Fedezeti hozzájárulás & +12 & +1 & +12 & +21 & +5 \\
\hline Ágazati eredmény & +23 & -17 & +28 & +40 & +30 \\
\hline Főtermék önköltsége & -7 & 0 & -10 & -1 & -6 \\
\hline Kölségarányos jövedelem & +10 & -36 & +23 & +2 & +24 \\
\hline
\end{tabular}

Forrás: Ágazati költség- és jövedelemelszámolási adatok alapján készült az AKI Horizontális Elemzési Osztályán

A gépköltség közel azonos (búza és repce) vagy kisebb volt a precíziós üzemeknél, a kukorica termesztése során 14, a napraforgónál 11, az árpánál pedig 13 százalékkal. Ebből a traktorok költsége minden esetben a precíziós gazdaságoknál volt alacsonyabb, a növénykultúráknál rendre $4,25,15$, 3 és 22 százalékkal. A termelési költség a búza és az árpa esetében 9, a napraforgónál 3 százalékkal volt magasabb a mintagazdaságokban. A termelés során felhasznált anyagok költségei szintén a kukoricánál és a repcetermesztésben voltak kiemelkedően magasak, előbbi 23, utóbbi pedig 19 százalékkal haladta meg a kontrollcsoport átlagát. Ezzel szemben a fedezeti hozzájárulás mértéke egyaránt felülmúlta a hagyományos gazdaságokét az összes vizsgált szántóföldi növénykultúra esetében. Az ágazati eredmények a kukoricától eltekintve szintén kedvezően alakultak, a búzatermesztés során 23 százalékos, napraforgónál 28 százalékos, árpánál 30 százalékos többletet eredményezett a technológia alkalmazása. A legmagasabb ágazati eredménybeli különbség az őszi káposztarepce termesztésében jelentkezett, átlagosan 40 (!) százalékkal nagyobb volt a bevételek és a költségek különbözeteként meghatározott eredmény. A kukoricánál ellenben 17 százalékkal kisebb ágazati eredményt értek el a precíziós termelők. A fötermék önköltsége minden növénynél alacsonyabb vagy egyenlő volt, a búzánál 7 százalékkal, napraforgónál 10 százalékkal és árpánál 6 százalékkal múlta alul az egységnyi termékre jutó elöállítási költség a hagyományos szántóföldi növénytermesztökét. A kukorica és a repce nem mutatott jelentős eltérést e tekintetben. A költségarányos jövedelem - szintén a kukorica kivételével - a főbb növénykultúráknál a precíziós gazdaságok esetében volt kedvezőbb 2-24 százalékkal. 


\subsection{A precíziós technológia gazdasági hatásainak kimutatása a 17 üzem körében a kontrollcsoport adataihoz viszonyítva}

Amennyiben kizárólag a precíziós technológiát legmagasabb szinten művelők képezték a vizsgálandó üzemek körét, szintén megállapítható volt, hogy a vetésterületek nagysága érdemben felülmúlta a hagyományos növénytermesztőkét, miközben a termőtalajok minőségében továbbra sem volt jelentős eltérés. A vetésterületnél tapasztalt számottevő méretkülönbség miatt az általuk elért eredmények szemléltetéséhez további feltételek megadására volt szükség a kontrollcsoport-képzésben. Másik problémaként jelentkezett, hogy a gazdaságok egy évre vonatkozó (2015) adatainak vizsgálata sem bizonyult elegendőnek, hiszen az évjárat hatását így nem lehetett kiszürni. Ebből következően a továbbiakban 3 év adatából számított átlagos értékekkel végeztük el a számításokat, amely 17 üzemnél állt rendelkezésre a precíziós gazdálkodás bevezetése előtt legalább 3 éves, utána legalább 2 éves időszakra. Vizsgálatunk a továbbiakban ezen üzemekre szükült.

A precíziós gazdálkodásban eltöltött idő alapján kiválasztott 17 üzem közül 12 búzát, 10 kukoricát, 8 napraforgót, 3 öszi árpát termesztett precíziós technológiával és mindössze 2 gazdaság foglalkozott repcével, így a kis elemszám miatt az őszi árpa és káposztarepce nem képezte a továbbiakban vizsgálatunk tárgyát. A gazdaságok által a növénykultúrákban alkalmazott technológiára jellemző, hogy leginkább menedzsmentzónás mủvelést végeznek. Az üzemeknél minden esetben a precíziós gazdálkodás bevezetésétől legtávolabb eső 3 év adatainak átlaga szerepel, hiszen minél hosszabb ideje végzik a növénytermesztést helyspecifikus módon, annál több tapasztalattal rendelkeznek a technológia alkalmazásáról. Továbbá az elemi kár miatt hozamkiesést elszenvedett évek nem képezték vizsgálatunk tárgyát.

A precíziós gazdaságok és a kontrollcsoportot képező hagyományos szántóföldi növénytermesztő üzemek vetésterülete között ismételten jelentős eltérés tapasztalható, ami a precíziós növénytermesztők javára írható. A hozamokat tekintve továbbra is minden esetben a precíziós gazdaságok bizonyultak jobbnak. A búzánál átlagosan 17, kukoricánál 2, napraforgónál pedig 6 százalékkal magasabb hozamokat produkáltak a precíziós termelők (8. táblázat), a termelési értéknél pedig ezek rendre 10, 11 és 3 százalék voltak. Mindhárom vizsgált ágazat összes bevétele a precíziós technológia bevezetését igazolja, amely a kukoricánál volt a legmeggyőzőbb, ennél a növénykultúránál átlagosan 27 százalékkal értek el több bevételt a termelök. Az inputanyagok-ráfordítások közül a vetőmagköltség a kukoricánál és a napraforgónál közel azonos volt, búza esetében pedig jelentősen, 25 százalékkal fordítottak kisebb összeget a vetőmagra. A mütrágyaköltség viszont változatosan alakult, a napraforgónál 4, a kukoricánál pedig 14 százalékkal alacsonyabb volt a hagyományos termesztéstechnológiát alkalmazókhoz képest, ezzel ellentétben a búzánál 37 százalékkal múlta felül azt. A precíziós szántóföldi növénytermesztők a kukorica és a napraforgó esetében 21, illetve 1 százalékkal kevesebb növényvédőszer-költséggel számolhattak a 2015. évben, a búzatermesztők viszont átlagosan 3 százalékkal nagyobb összeget fordítottak növényvédelemre. A gépköltség és ezen belül a traktorok költsége átlagosan 7 százalékkal tért el a kontrollcsoportétól a kukoricánál, míg 1-1 százalékkal a búza és a napraforgó esetében. A termelési költség ellenben az előző számításhoz képest módosult, a búzában 1 százalékkal, kukoricánál 5, a napraforgónál pedig 8 százalékkal volt kevesebb. A főtermék önköltsége minden növénynél alacsonyabb volt, rendre 17, 13 és 17 százalékkal. Minden esetben a precíziós növénytermesztési technológiát használók értek el magasabb fedezeti hozzájárulást és ágazati eredményt. A kukoricánál és a búzánál kimagasló volt az utóbbi értéke, átlagosan 44 és 59 (!) százalékkal nagyobb jövedelmet realizáltak a precíziós gazdaságok a kontrollcsoporthoz képest, míg a napraforgónál 34 százalékkal volt magasabb ez az érték. Az ágazati eredményhez hasonlóan a költségarányos jövedelem is jelentősen magasabb a precíziós gazdaságoknál, búza esetében 41, kukoricánál 70, napraforgónál pedig 34 százalékkal. 
8. táblázat: A vizsgált ágazatok fóbb mutatóinak átlagos eltérése a precíziós technológia alkalmazásának hatására a 17 kiemelt üzemnél

százalék

\begin{tabular}{lccc}
\hline \multicolumn{1}{c}{ Ágazati mutatók } & Búza & Kukorica & Napraforgó \\
\hline Hozam & +17 & +2 & +6 \\
\hline Termelési érték & $\mathbf{+ 1 0}$ & $+\mathbf{1 1}$ & $\mathbf{+ 3}$ \\
\hline Ágazat összes bevétele & +4 & +27 & +7 \\
\hline Inputanyagköltségek & & & 0 \\
\hline vetömagköltség & -25 & +2 & -4 \\
\hline mütrágyaköltség & +37 & -14 & -1 \\
\hline növényvédöszer-költség & +3 & -21 & -1 \\
\hline Gépköltség & -1 & +7 & -1 \\
\hline ebböl: & & & $-\mathbf{8}$ \\
\hline traktorok költsége & 0 & +2 & +7 \\
\hline Termelési költség & $-\mathbf{1}$ & $-\mathbf{5}$ & $+\mathbf{3 4}$ \\
\hline Fedezeti hozzájárulás & +10 & +24 & -17 \\
\hline Ágazati eredmény & $+\mathbf{4 4}$ & $+\mathbf{5 9}$ & +34 \\
\hline Főtermék önköltsége & -17 & -13 & +70 \\
\hline Költségarányos jövedelem & +41 & & \\
\hline
\end{tabular}

Forrás: Ágazati költség- és jövedelemelszámolási adatok alapján készült az AKI Horizontális Elemzési Osztályán

\subsection{A precíziós technológia gazdasági hatásainak kimutatása a 17 üzem körében a kontrollcsoport megválasztásának módosításával}

Mivel a vetésterület az előző számításban jelentős eltérést mutatott, ezért a további számításoknál igyekeztünk a kontrollcsoportot úgy lehatárolni, hogy ezeket az eltéréseket mérsékeljük. Az összehasonlítás alapjául szolgáló üzemek körét azon gazdaságokra szükítettük le, amelyeknél a vetésterület nagysága maximálisan \pm 20 százalékos eltéréssel bír a precíziós üzemekhez képest. Továbbá az intenzív üzemekhez a magasabb inputanyag-felhasználású gazdaságok, a kisebb termelési intenzitású üzemekhez pedig szintén a hozzájuk hasonló, azaz az alacsonyabb inputanyag-felhasználású gazdaságok kerültek kiválasztásra, melyek legfeljebb \pm 20 százalékos eltéréssel bírnak. A többi paraméter változatlan maradt az elemzés során.

A számítások eredményeképpen a búzaágazatban 14 százalékkal magasabb hozamokat, 8 százalékkal nagyobb termelési értéket tudhattak magukénak a precíziós üzemek a kontrollcsoportot képező gazdaságokhoz képest (9. táblázat). Az ágazat összes bevétele szintén felülmúlta a hagyományos növénytermesztő üzemekét, összességében 1 százalékkal. A búza termesztése során vetőmagra 26 százalékkal, növényvédő szerre pedig 6 százalékkal kisebb összeget fordítottak. Ezzel ellentétben 26 százalékkal többet költöttek mütrágyára a precíziós technológiát alkalmazók. A gépköltség 1 százalékos, ezen belül a traktorok költsége 2 százalékos eltérést mutatott a precíziós gazdálkodók rovására. A termelés során jelentkezö összes költség (termelési költség) átlagosan 3 százalékkal volt magasabb a hagyományos üzemekben, azaz az intenzitás alapján szinte teljesen azonos üzemek kerültek elemzésre a számítás során. A fedezeti hozzájárulás 11 százalékkal volt nagyobb a precíziós üzemeknél. Hasonlóan kedvezően alakult a bevételek és költségek különbözeteként számított jövedelem, amelyben szintén a precíziós üzemek bizonyultak eredményesebbnek, méghozzá 43 százalékkal magasabb ágazati eredményt értek el. Emellett a helyspecifikus termesztéstechnológiát alkalmazók átlagosan 17 százalékkal alacsonyabb önköltségen tudták előállítani terményüket, továbbá a költségarányos jövedelem 16 százalékponttal volt magasabb. 
9. táblázat: A búzaágazat főbb mutatóinak alakulása a precíziós gazdaságokban és a hagyományos növénytermesztő üzemekben

\begin{tabular}{|c|c|c|c|}
\hline Ágazati mutatók & $\begin{array}{c}\text { Precíziós } \\
\text { gazdaságok } \\
\text { (átlagos érték) }\end{array}$ & $\begin{array}{l}\text { Hagyományos növény- } \\
\text { termesztő üzemek } \\
\text { (átlagos érték) }\end{array}$ & $\begin{array}{l}\text { Átlagos eltérés, } \\
\text { százalék }\end{array}$ \\
\hline Hozam, tonna/hektár & 5,81 & 5,10 & +14 \\
\hline Termelési érték, HUF/ha & 262192 & 243175 & +8 \\
\hline Ágazat összes bevétele, HUF/ha & 227390 & 225902 & +1 \\
\hline \multicolumn{4}{|l|}{ Inputanyagköltségek } \\
\hline vetömagköltség, $H U F / h a$ & 14725 & 19970 & -26 \\
\hline mütrágyaköltség, HUF/ha & 58478 & 46314 & +26 \\
\hline növényvédöszer-költség, HUF/ha & 20951 & 22214 & -6 \\
\hline Gépköltség, HUF/ha & 37582 & 37248 & +1 \\
\hline \multicolumn{4}{|l|}{ ebböl: } \\
\hline traktorok költsége, HUF/ha & 26649 & 26207 & +2 \\
\hline Termelési költség, HUF/ha & 178081 & 184215 & -3 \\
\hline Fedezeti hozzájárulás, HUF/ha & 165452 & 149620 & +11 \\
\hline Ágazati eredmény, HUF/ha & 84111 & 58960 & +43 \\
\hline Főtermék önköltsége, HUF/tonna & 30917 & 37324 & -17 \\
\hline Költségarányos jövedelem, százalék & 50 & 34 & +49 \\
\hline
\end{tabular}

Forrás: Ágazati költség- és jövedelemelszámolási adatok alapján készült az AKI Horizontális Elemzési Osztályán

A kukoricaágazatban a precíziós technológiát alkalmazóknál szintén kedvezőbben alakultak a költség- és jövedelemelszámolási adatok. Azok a gazdálkodók, akik helyspecifikus módon termesztették a kukoricájukat, átlagosan 2 százalékkal növelték hozamaikat, 13 százalékkal a termelési értéküket és 34 százalékkal az összes bevételüket (10. táblázat). Az inputanyag-felhasználás a búzaágazatban megvalósult gyakorlattól eltérő volt, a vetőmagköltség 8 százalékkal nagyobb volt a precíziós gazdaságoknál, míg a mütrágya költsége 6 százalékkal, a növényvédő szeré 18 százalékkal kisebb volt. A ráfordításelemek közül a gépek költsége 7 százalékkal múlta felül a hagyományos szántóföldi növénytermesztőkét. A gépköltségeken belül a traktorok ráfordításai átlagosan 2 százalékkal magasabbak voltak a precíziós gazdaságokban. A precíziós üzemek termeléshez felhasznált költségei átlagosan azonos mértéküek voltak a kontrollcsoportban szereplö üzemekéhez viszonyítva, vagyis a precíziós kukoricatermesztő üzemek és azok kontrollcsoportja között az intenzitásbeli eltéréssel nem kell számolni. Mindezek eredményeképpen a termelési érték és a változó költségek különbözeteként meghatározott fedezeti hozzájárulás és az ágazati eredmény egyaránt ebben az ágazatban is meghaladta a hagyományos szántásos technológiával gazdálkodó termelőkét 22, illetve 44 százalékkal. Ezáltal az egységnyi főtermékre eső költséget 8 százalékkal mérsékelni tudták a precíziós technológia hatására, emellett a költségarányos jövedelem 22 százalékponttal volt magasabb a precíziós gazdaságoknál. 
10. táblázat: A kukoricaágazat főbb mutatóinak alakulása a precíziós gazdaságokban és a hagyományos növénytermesztő üzemekben

\begin{tabular}{|c|c|c|c|}
\hline Ágazati mutatók & $\begin{array}{c}\text { Precíziós } \\
\text { gazdaságok } \\
\text { (átlagos érték) }\end{array}$ & $\begin{array}{l}\text { Hagyományos növény- } \\
\text { termesztő üzemek } \\
\text { (átlagos érték) }\end{array}$ & $\begin{array}{c}\text { Átlagos eltérés, } \\
\text { százalék }\end{array}$ \\
\hline Hozam, tonna/hektár & 7,06 & 6,93 & +2 \\
\hline Termelési érték, HUF/ha & 330796 & 293448 & +13 \\
\hline Ágazat összes bevétele, HUF/ha & 327226 & 243932 & +34 \\
\hline \multicolumn{4}{|l|}{ Inputanyagköltségek } \\
\hline vetömagköltség, $H U F / h a$ & 35101 & 32455 & +8 \\
\hline mütrágyaköltség, $H U F / h a$ & 33446 & 35699 & -6 \\
\hline növényvédöszer-költség, HUF/ha & 16617 & 20247 & -18 \\
\hline Gépköltség, HUF/ha & 44575 & 41787 & +7 \\
\hline \multicolumn{4}{|l|}{ ebböl: } \\
\hline traktorok költsége, HUF/ha & 31802 & 31049 & +2 \\
\hline Termelési költség, HUF/ha & 208419 & 208273 & $\mathbf{0}$ \\
\hline Fedezeti hozzájárulás, HUF/ha & 224481 & 184187 & +22 \\
\hline Ágazati eredmény, HUF/ha & 122377 & 85175 & +44 \\
\hline Főtermék önköltsége, HUF/tonna & 30204 & 32661 & -8 \\
\hline Költségarányos jövedelem, százalék & 66 & 44 & +50 \\
\hline
\end{tabular}

Forrás: Ágazati költség- és jövedelemelszámolási adatok alapján készült az AKI Horizontális Elemzési Osztályán

A napraforgó-termesztés gyakorlatában precíziós technológiát használó üzemek átlagosan 9 százalékos hozamtöbbletet értek el a szántásos művelést végzőkhöz képest (11. táblázat), ami termelési értékben 7 százalékos többletet jelentett. A napraforgó-ágazat bevétele összességében 11 százalékkal múlta felül a hagyományos üzemekét. A termelés költségei együttesen 2 százalékkal tértek el, amely alátámasztja, hogy hasonló intenzitású üzemek kerültek kiválasztásra a kontrollcsoport meghatározása során. A ráfordításokon belül a vetőmagköltség ( 2 százalékos), a mütrágya (14 százalékos) és a növényvédő szer költségének ( 8 százalékos) átlagos növekedése volt jellemző. A magas ráfordítási összegek ellenére az állandó költségek térítésére felhasználható összeg, azaz a fedezeti hozzájárulás 8 százalékkal nagyobb volt, továbbá ebben az ágazatban is a precíziós technológia alkalmazásával lehetett - 29 százalékkal - magasabb eredményt elérni. A vizsgált helyspecifikus technológiát alkalmazók egyértelműen hatékonyabban gazdálkodtak a 2015. évben, amelyet a hozamegységre jutó költség (önköltség) 14 százalékkal alacsonyabb mértéke is alátámaszt. Emellett egységnyi költséggel magasabb jövedelmet tudtak elérni, összességében 13 százalékponttal. 
11. táblázat: A napraforgóágazat fôbb mutatóinak alakulása a precíziós gazdaságokban és a hagyományos növénytermesztő üzemekben

\begin{tabular}{|c|c|c|c|}
\hline Ágazati mutatók & $\begin{array}{l}\text { Precíziós gazdaságok } \\
\text { (átlagos érték) }\end{array}$ & $\begin{array}{l}\text { Hagyományos növény- } \\
\text { termesztő üzemek } \\
\text { (átlagos érték) }\end{array}$ & $\begin{array}{l}\text { Átlagos eltérés, } \\
\text { százalék }\end{array}$ \\
\hline Hozam, tonna/hektár & 2,76 & 2,54 & +9 \\
\hline Termelési érték, HUF/ha & 266722 & 249725 & +7 \\
\hline Ágazat összes bevétele, HUF/ha & 267907 & 240904 & +11 \\
\hline \multicolumn{4}{|l|}{ Inputanyagköltségek } \\
\hline vetömagköltség, $H U F / h a$ & 23393 & 23045 & +2 \\
\hline mütrágyaköltség, $H U F / h a$ & 28572 & 25084 & +14 \\
\hline növényvédöszer-költség, HUF/ha & 26821 & 24734 & +8 \\
\hline Gépköltség, HUF/ha & 43197 & 44917 & -4 \\
\hline \multicolumn{4}{|l|}{ ebböl: } \\
\hline traktorok költsége, HUF/ha & 33256 & 34796 & -4 \\
\hline Termelési költség, HUF/ha & 171017 & 175252 & -2 \\
\hline Fedezeti hozzájárulás, HUF/ha & 184994 & 170630 & +8 \\
\hline Ágazati eredmény, HUF/ha & 95705 & 74474 & +29 \\
\hline Főtermék önköltsége, HUF/tonna & 62636 & 73188 & -14 \\
\hline Költségarányos jövedelem, százalék & 57 & 44 & +28 \\
\hline
\end{tabular}

Forrás: Ágazati költség- és jövedelemelszámolási adatok alapján készült az AKI Horizontális Elemzési Osztályán

Összességében megállapítható, hogy a magasabb ráfordítások jóval magasabb ágazati jövedelmet eredményeznek, vagyis az erőforrás-felhasználás a precíziós üzemeknél volt hatékonyabb. A kutatás eredménye alapján a költségekben nem lehetett egyértelmüen csökkenésre számítani, hiszen ahogy azt Schieffer és Dillon (2014) a vizsgálataik során kimutatta, a gazdaságok ráfordításai nem minden esetben mérséklődtek a technológiának köszönhetően. Ennek oka, hogy amennyiben az üzemek a korábbi inputfelhasználásukat növelik, és az megtérül a hozamok emelkedésében, akkor az egyértelmúen arra ösztönzi a gazdaságokat, hogy tovább növeljék az inputanyag-mennyiséget a termelés során. Ezt támasztják alá a felmérési eredmények, miszerint a precíziós gazdaságok hozamai és inputanyag-ráfordításai egyaránt felülmúlták a hagyományos szántóföldi növénytermesztőkét. A bevételek növekedése viszont túlszárnyalta a költségek emelkedését, így az ágazati eredmény szinte minden esetben a precíziós technológiát alkalmazóknál volt magasabb. Ennek értelmében a hatékonyság növekedését sikerült igazolni a számításaink során.

\subsection{Eredmények igazolása statisztikai módszerekkel}

A kutatás során feltételeztük, hogy a precíziós gazdálkodás bevezetése egyértelmü hozamtöbbletet, költségmegtakarítást és jövedelmezőségi előnyt eredményez a szántóföldi növénytermesztők számára (H2). A hipotézis ellenőrzését statisztikai módszerekkel végeztük el. A búza esetében a vizsgálat 12 precíziós üzemre és 12 hagyományosan gazdálkodó üzemre terjedt ki. Az elemzés 3 év adatait tartalmazza az egyes növénykultúrák esetében, így a minta sokasága 36, illetve 35. A két csoport különbsége abból adódik, hogy egy precíziós búzatermesztő gazdaság egy évéhez nem lehetett kontrollüzemeket párosítani a megadott feltételek mellett. A kukoricánál 8-8 kultúra képezte a vizsgálandó sokaság körét, azaz 24 esetet lehetett elemezni, míg a napraforgónál a búzához hasonlóan egy esetben nem volt összehasonlításra alkalmas adat, így 8 precíziós technológiával termesztett növény esetén 24 , illetve 23 érték statisztikai elemzése valósult meg. 
Az eloszlásvizsgálat során három esetben az interkvartilis terjedelem legalább másfélszeresénél is nagyobb az abszolút eltérés, de akár a háromszorosát is meghaladja. A kiugró érték magyarázata az alacsony hozamszint esetében valószínűleg elemi kár miatti hozamkiesés, amely nem került bejelentésre, vagy akár egy nagyobb tápanyagmennyiséget igénylő elővetemény is okozhatta. Azon kontrollcsoportok is kizárásra kerültek a sokaságból, amelyek az adott évre kevés elemszámmal rendelkeznek, így a vizsgálandók köre szükítésre került, melyre vonatkozó alapadatokat a 12. táblázat tartalmazza.

12. táblázat: Csoporton belüli adatok

\begin{tabular}{|c|c|c|c|c|c|c|c|}
\hline \multirow{3}{*}{ : } & \multirow{3}{*}{ Kategória } & \multirow{3}{*}{$\mathbf{N}$} & Hozamátlag & $\begin{array}{c}\text { Termelési } \\
\text { érték }\end{array}$ & $\begin{array}{c}\text { Termelési } \\
\text { költség }\end{array}$ & $\begin{array}{c}\text { Ágazati } \\
\text { eredmény }\end{array}$ & Önköltség \\
\hline & & & átlag & átlag & átlag & átlag & átlag \\
\hline & & & tonna/hektár & HUF/hektár & HUF/hektár & HUF/hektár & HUF/hektár \\
\hline \multirow{3}{*}{$\stackrel{\widetilde{N}}{\tilde{n}}$} & Precíziós & 36 & 5,52 & 252174 & 183189 & 68986 & 33626 \\
\hline & Nem precíziós & 33 & 5,05 & 236609 & 179376 & 57233 & 36656 \\
\hline & Összesen & 69 & 5,30 & 244730 & 181365 & 63365 & 35075 \\
\hline \multirow{3}{*}{$\begin{array}{l}. \frac{0}{0} \\
\frac{0}{\overrightarrow{0}} \\
\frac{\vec{a}}{4}\end{array}$} & Precíziós & 24 & 7,56 & 335352 & 208134 & 127218 & 28288 \\
\hline & Nem precíziós & 24 & 6,74 & 286519 & 206001 & 80518 & 33267 \\
\hline & Összesen & 48 & 7,15 & 310935 & 207068 & 103868 & 30777 \\
\hline \multirow{3}{*}{ 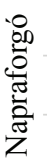 } & Precíziós & 23 & 2,90 & 292299 & 168728 & 123572 & 58550 \\
\hline & Nem precíziós & 23 & 2,54 & 246379 & 168988 & 77391 & 70761 \\
\hline & Összesen & 46 & 2,72 & 269339 & 168858 & 100481 & 64656 \\
\hline
\end{tabular}

Forrás: Ágazati költség- és jövedelemelszámolási adatok alapján SPSS program segítségével készült az AKI Horizontális Elemzési Osztályán

A változók Shapiro-Wilk-teszttel történő normalitásvizsgálata során a nullhipotézis, azaz a változók normalitásának teljesülése elfogadásra került (7. melléklet). Mivel a változók normáleloszlást követnek a csoporton belül, így lehetőség adódott a varianciaelemzés elvégzésére. Az ANOVA-teszt (ANalysis Of VAriance) segítségével a precíziós és nem precíziós sokaságok közötti szignifikáns összefüggés vizsgálata valósult meg az alábbi változók esetén: hozamátlag, termelési érték, termelési költség, önköltség és ágazati eredmény.

Az ANOVA-modell lefuttatásával megállapítható, hogy a precíziós termesztési technológia búza esetén a hozamra és az önköltségre, illetve kukorica és napaforgó esetén a hozamra, a termelési értékre, az ágazati eredményre és az önköltségre való hatása szignifikáns (13. táblázat). Ennek értelmében a búza esetén a precíziós technológia alkalmazása egyértelműen hatással van a hozamok és az önköltség alakulására, míg a kukoricánál és a napraforgónál a hozam, a termelési érték, az ágazati eredmény és az önköltség változására egyaránt.

A modell által megmagyarázott hányadot a 14. táblázat éta-értékei tartalmazzák. Összességében kimutatható, hogy mind a három növénykultúrában a hozam és az önköltség a precíziós technológia alkalmazásának függvényében eltérő, míg a termelési költség esetén azért nem mutatható ki szignifikáns eltérés egyetlen növénykultúrában sem, mert a vizsgálat során \pm 20 százalékos intervallum került meghatározásra a kontrollcsoport kiválasztásánál annak érdekében, hogy az intenzitások megegyezőek legyenek. 
13. táblázat: ANOVA-teszt eredménye

\begin{tabular}{|c|c|c|c|c|c|c|c|c|c|c|}
\hline \multirow[t]{2}{*}{ Növény } & \multicolumn{2}{|c|}{ Hozamátlag } & \multicolumn{2}{|c|}{ Termelési érték } & \multicolumn{2}{|c|}{$\begin{array}{c}\text { Termelési } \\
\text { költség }\end{array}$} & \multicolumn{2}{|c|}{$\begin{array}{c}\text { Ágazati } \\
\text { eredmény }\end{array}$} & \multicolumn{2}{|c|}{ Önköltség } \\
\hline & $\mathbf{F}$ & Szig. & $\mathbf{F}$ & Szig. & $\mathbf{F}$ & Szig. & F & Szig. & F & Szig. \\
\hline Búza & 5,17 & 0,03 & 2,057 & 0,16 & 0,18 & 0,68 & 1,52 & 0,22 & 3,99 & 0,05 \\
\hline Kukorica & 4,24 & 0,05 & 13,902 & 0,00 & 0,03 & 0,86 & 9,96 & 0,00 & 6,86 & 0,01 \\
\hline Napraforgó & 14,02 & 0,00 & 8,56 & 0,01 & 0,00 & 0,97 & 11,08 & 0,00 & 21,33 & 0,00 \\
\hline
\end{tabular}

Forrás: Ágazati költség- és jövedelemelszámolási adatok alapján SPSS program segítségével készült az AKI Horizontális Elemzési Osztályán

14. táblázat: A modell által magyarázott hányad (éta)

\begin{tabular}{lccccccccccc}
\hline \multirow{2}{*}{ Növény } & \multicolumn{2}{c}{ Hozamátlag } & \multicolumn{2}{c}{ Termelési érték } & \multicolumn{2}{c}{$\begin{array}{c}\text { Termelési } \\
\text { költség }\end{array}$} & \multicolumn{2}{c}{$\begin{array}{c}\text { Ágazati } \\
\text { eredmény }\end{array}$} & \multicolumn{2}{c}{ Önköltség } \\
\cline { 2 - 12 } & éta & $\begin{array}{c}\text { éta- } \\
\text { négyzet }\end{array}$ & éta & $\begin{array}{c}\text { éta- } \\
\text { négyzet }\end{array}$ & éta & $\begin{array}{c}\text { éta- } \\
\text { négyzet }\end{array}$ & éta & $\begin{array}{c}\text { éta- } \\
\text { négyzet }\end{array}$ & éta & $\begin{array}{c}\text { éta- } \\
\text { négyzet }\end{array}$ \\
\hline Búza & 0,27 & 0,07 & 0,17 & 0,03 & 0,05 & 0,00 & 0,15 & 0,02 & 0,24 & 0,06 \\
\hline Kukorica & 0,29 & 0,08 & 0,48 & 0,23 & 0,03 & 0,00 & 0,42 & 0,18 & 0,36 & 0,13 \\
\hline Napraforgó & 0,49 & 0,24 & 0,40 & 0,16 & 0,01 & 0,00 & 0,45 & 0,20 & 0,57 & 0,33 \\
\hline
\end{tabular}

Forrás: Ágazati költség- és jövedelemelszámolási adatok alapján SPSS program segítségével készült az AKI Horizontális Elemzési Osztályán

A 15. táblázat a csoportátlagokat és a csoportátlagok fóátlagtól való eltérését tartalmazza. Jól látható, hogy a precíziós búzatermesztő gazdaságok a hagyományos üzemekhez képest egyértelmúen magasabb fajlagos hozamot realizálnak, illetve egységnyi termésmennyiség előállítására kevesebb költséget fordítanak. Azok a gazdaságok, amelyek a kukorica és a napraforgó termesztése során precíziós technológiát alkalmaznak, szignifikánsan nagyobb termésmennyiséget takarítanak be egy hektárról, illetve magasabb jövedelmezőséget érnek el a hagyományos szántóföldi növénytermesztő üzemekhez képest. Az önköltség ezen növénykultúrák esetében szintén alacsonyabb, azaz hatékonyabban gazdálkodnak a hagyományos müvelést végzőkhöz képest.

\section{5. táblázat: A csoportátlag fóátlagtól való eltérése}

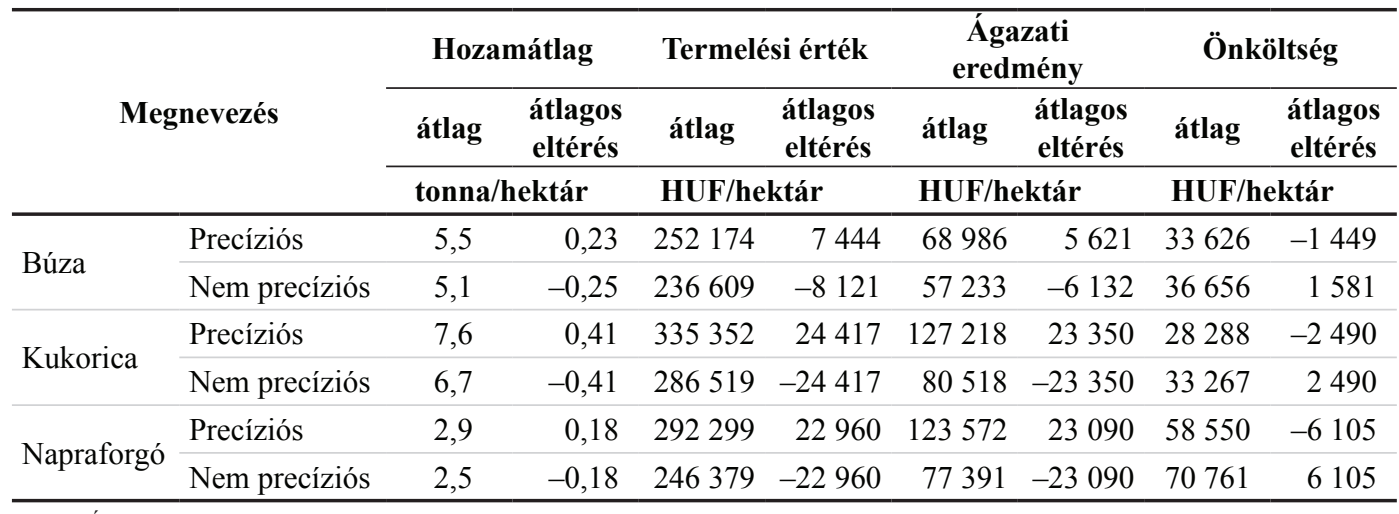

Forrás: Ágazati költség- és jövedelemelszámolási adatok alapján SPSS program segítségével készült az AKI Horizontális Elemzési Osztályán

Összességében az állítás, miszerint a precíziós technológia egyértelmű többlethozamot és magasabb jövedelmet eredményez, mindemellett növeli a termelés hatékonyságát azáltal, hogy egységnyi költséggel magasabb hozamokat érnek el, a napraforgó és kukorica esetében teljes mértékben igazolható a fenti számítások alapján. A búzatermesztésben magasabb hozamok és az önköltség csökkenése mutatható ki, az ágazati eredmény viszont nem növekedett szignifikánsan, így a magasabb jövedelemre vonatkozó hipotézis elvetésre került. 


\subsection{A precíziós technológia gazdasági hatásainak kimutatása a 17 üzem körében 6 év (3 precíziós elötti, 3 utáni) adatai alapján}

Kizárólag a precíziós szántóföldi növénytermesztés gazdasági előnyeit a hagyományos termesztéshez képest úgy célszerü kimutatni, hogy a müvelési módtól eltekintve minden más tényező azonos az összehasonlítandó üzemek esetében, így például a természeti adottságok (domborzat, talajadottságok stb.), a táblaméret, az üzemméret stb. Ezt szem előtt tartva mindenképpen indokolt a precíziós technológiára áttért üzemek önmagukkal való összehasonlítása. Meg kell azonban jegyezni, hogy az időbeli összehasonlításnál az időjárási hatások kiszürésére csak korlátozottan adódik lehetőség. Követve az egyes üzemek évről évre történő fejlődését összehasonlítottuk a hosszabb ideje (legalább három éve) precíziós gazdálkodást végző 17 üzem technológiaváltást megelőző adatait a bevezetés utáni évek értékeivel. A számítások az éves adatok mellett az egyes növénykultúrák precíziós termesztésben töltött utolsó 3 évi költség- és jövedelemelszámolási adatai átlagának, illetve az alkalmazás előtti három év átlagának hányadosát is tartalmazzák. Az üzemeket az ABC betűivel különböztetjük meg.

A 17 üzem közel fele (8 üzem) 50 és 250 hektár közötti termőterületet mủvelt precíziós technológiával, 29,4 százaléka 50 hektárnál kisebb területen gazdálkodott, 23,5 százalékának vetésterülete pedig a 250 hektárt is meghaladta (24. ábra).

\section{4. ábra: A 2015. évben precíziósan müvelt területek megoszlása az üzemek között}

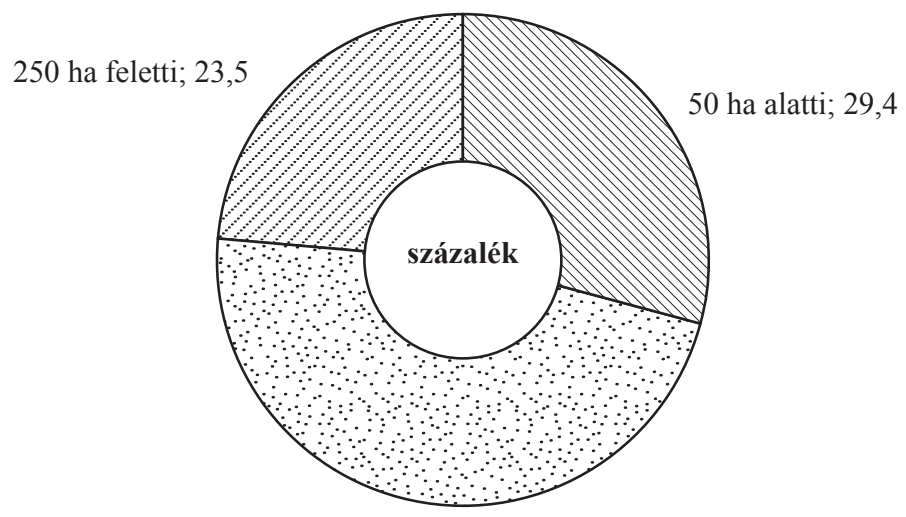

50-250 ha közötti; 47,1

Forrás: Kérdőíves felmérés adatai alapján készült az AKI Horizontális Elemzési Osztályán

A vizsgált precíziós gazdaságok több mint háromnegyede a vetésterület teljes egészén vagy megközelítőleg 100 százalékán végzi a helyspecifikus technológiát, míg 17,6 százalékuk azon növénykultúrában, amelyet precíziós gazdálkodással mủvel, a teljes vetésterület több mint felén alkalmazza a technológiát. Mindössze egy üzem gazdálkodására volt jellemző, hogy precíziós technológiával a vetésterületének kevesebb mint 50 százalékán termeszti az adott növénykultúrát (25. ábra).

A 17 üzem által termesztett növények közül 16 növényt, összesen 4-féle növénykultúrát (búza, kukorica, napraforgó, őszi árpa) műveltek precíziós technológiával 50 hektárnál kisebb területen. A 16 növény közül 11 esetben magasabb ágazati eredményt értek el a modernebb technológia alkalmazásával. Azok az üzemek, amelyek az egyes növénykultúrákat 50-250 hektár közötti vetésterületen müvelték, ágazati szinten 8 növény esetében ${ }^{3}$ gazdálkodtak eredményesebben a technológia

\footnotetext{
3 Magasabb ágazati eredményt a következö növénykultúrák termesztésében értek el a gazdálkodók: búza, kukorica, csemegekukorica és napraforgó.
} 
segítségével. A 250 hektár feletti vetésterület-méreteknél egyértelmüen kimutatható volt az üzemek által realizált ágazati eredménytöbblet, amelyet a helyspecifikus növénytermesztés eredményezett (26. ábra). Összességében az üzemek által termesztett 35 növény közül 23 esetben növekedett az ágazati eredmény, 12 esetben pedig nem volt kimutatható a jövedelembővülés a technológia alkalmazásának hatására (8. melléklet).

\section{5. ábra: A 2015. évben precíziósan múvelt területek aránya a vetésterülethez képest az egyes növénykultúrákban}

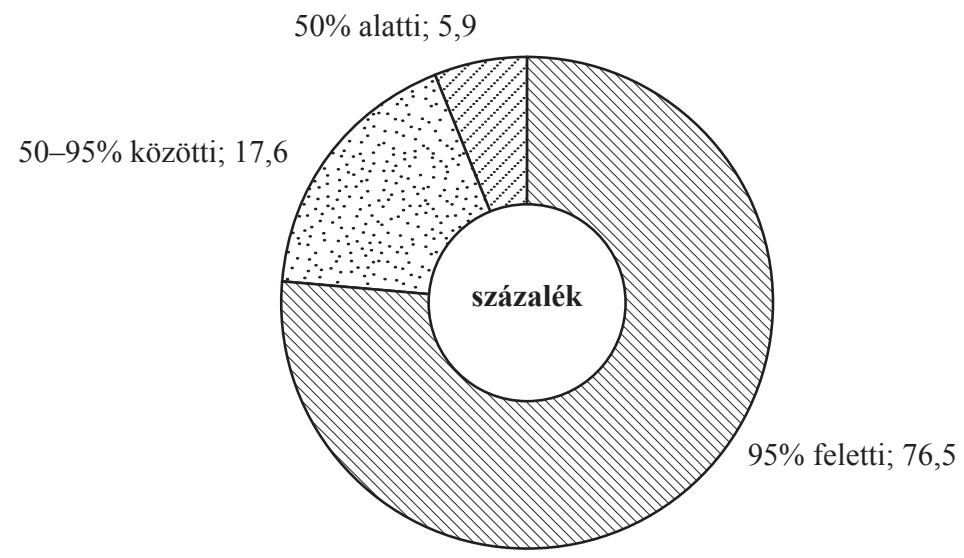

Forrás: Ágazati költség- és jövedelemelszámolási adatok és a kérdőíves felmérés adatai alapján készült az AKI Horizontális Elemzési Osztályán

26. ábra: Az ágazati eredmények változása a 2015. évben precíziósan múvelt vetésterületméretkategóriákban

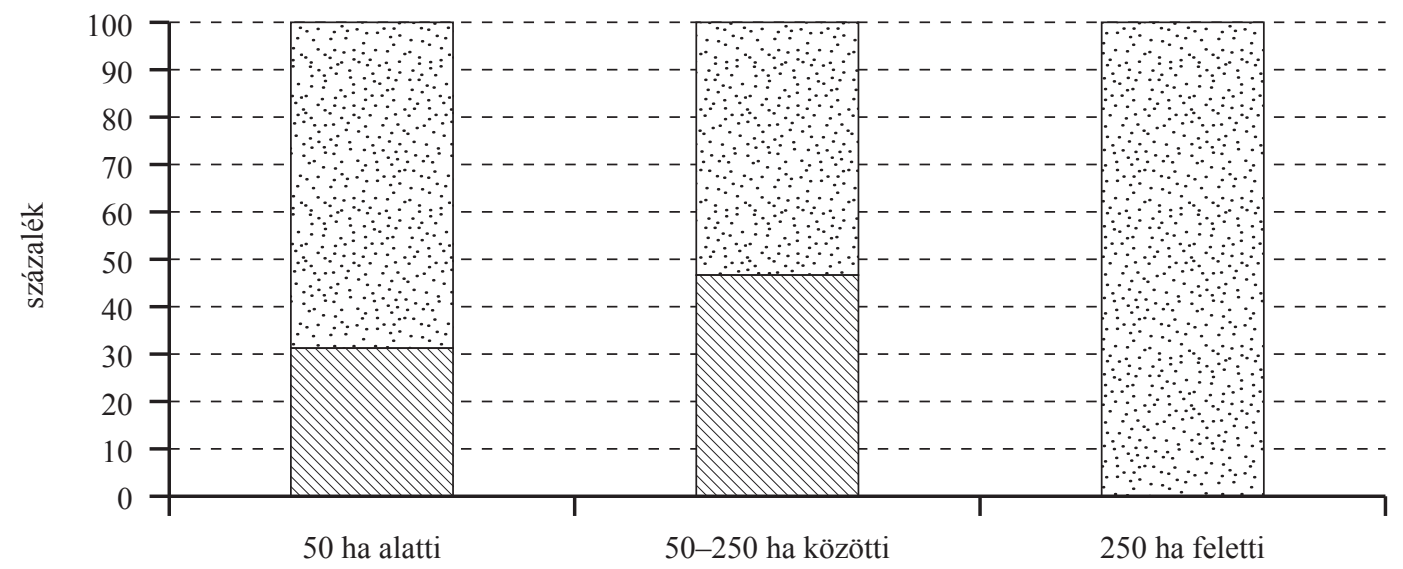

Csökkent

Nött

Forrás: Ágazati költség- és jövedelemelszámolási adatok és a kérdőíves felmérés adatai alapján készült az AKI Horizontális Elemzési Osztályán 
Az egységnyi ráfordítással előállított termelési érték az 50 hektárnál kisebb területen termesztett növények többségében (62,5 százalékában), az 50-250 hektár közötti vetésterület esetében az üzemek 53,3 százalékában nőtt a precíziós technológia bevezetése utáni években (27. ábra). A 250 hektáros területméret felett ugyanakkor már a növények 75 százalékában nagyobb hatékonyságot értek el az üzemek a technológia alkalmazásának hatására.

Itt fontos megemlíteni, hogy a termelési költség részét képezi az értékcsökkenési leírás is, amely a technológia bevezetéséhez szükséges eszközberuházás miatt az alkalmazott években magasabb, amely a termelési költséget jelentősen megnöveli.

Összességében a 35 precíziósan termesztett növénykultúra közül 17 növény esetében, azaz kevesebb mint 50 százalékában sikerült kimutatni hatékonyságnövekedést a technológia alkalmazásának eredményeképpen (9. melléklet).

\section{7. ábra: A termelési érték és a termelési költség hányadosának alakulása a 2015. évben precíziósan múvelt vetésterület-méretkategóriákban}

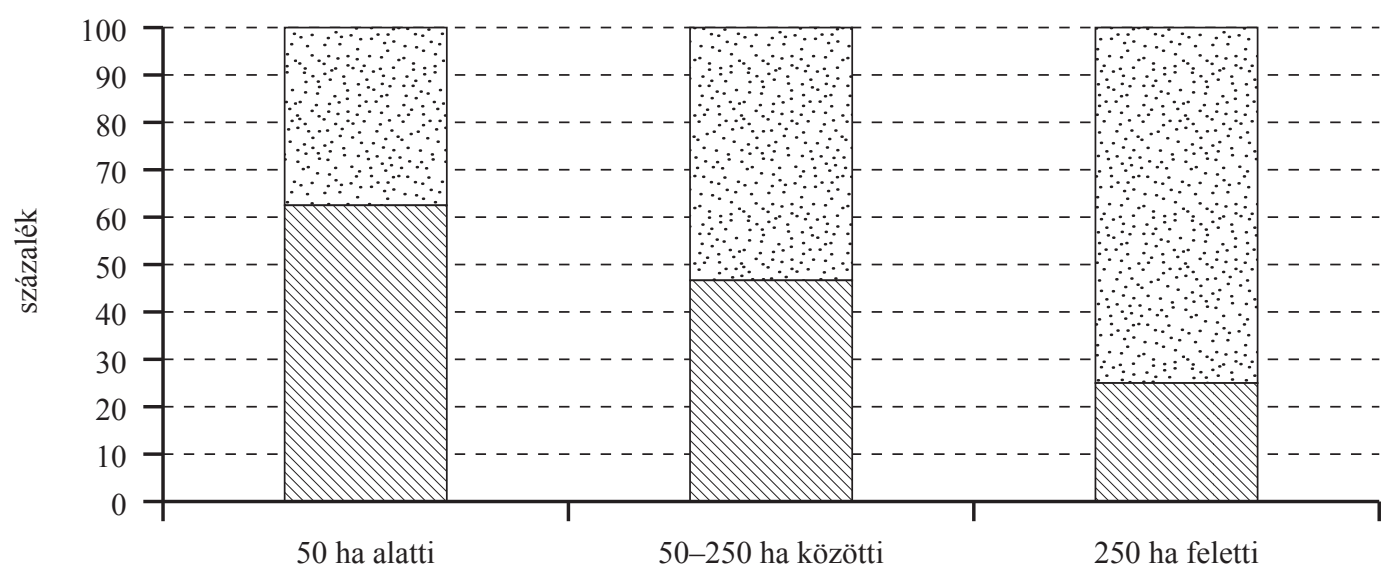

MIV Csökkent $\quad \therefore \because$ Nött

Forrás: Ágazati költség- és jövedelemelszámolási adatok és a kérdőíves felmérés adatai alapján készült az AKI Horizontális Elemzési Osztályán

A 35 növény hozamátlagainak vizsgálatakor az ágazati költség- és jövedelemadatok lehetőséget adtak azoknak az éveknek a kiszürésére, amelyek során elemi kár okozta hozamkiesést szenvedett el a gazdaság, ezáltal lehetővé vált a technológia hozamokra gyakorolt hatásának pontosabb kimutatása. Így az időjárás okozta hozamcsökkenést elszenvedett üzemek károsult évi adatai nem kerültek figyelembevételre az elemzéskor. A vizsgált évek szelektálása után az „A” üzem és a „P” üzem kukorica növénykultúrájánál kevesebb mint 3 évre állt rendelkezésre adat a precíziós technológia bevezetését követően, így ezen gazdaságok hozamátlagainak alakulását nem lehetett vizsgálni.

Az inputanyag növelésének köszönhetően mindössze 7 növény hozama volt alacsonyabb a precíziós technológia bevezetése elötti három év átlagában az alkalmazást követő évekhez viszonyítva (28. ábra), míg az üzemek a precíziósan termesztett növények 80,0 százalékánál átlagosan 16,5 százalékkal tudták növelni a hozamokat a helyspecifikus technológia hatására. Azok körében tehát, akik precíziós technológiát alkalmaztak a termesztési gyakorlatukban, sikerült igazolni a hagyományostól eltérő gazdálkodás hozamnövelő hatását. 
28. ábra: Hozamátlagok alakulása a precíziós üzemeknél a technológia bevezetése előtti és az alkalmazást követő 3 év átlagában

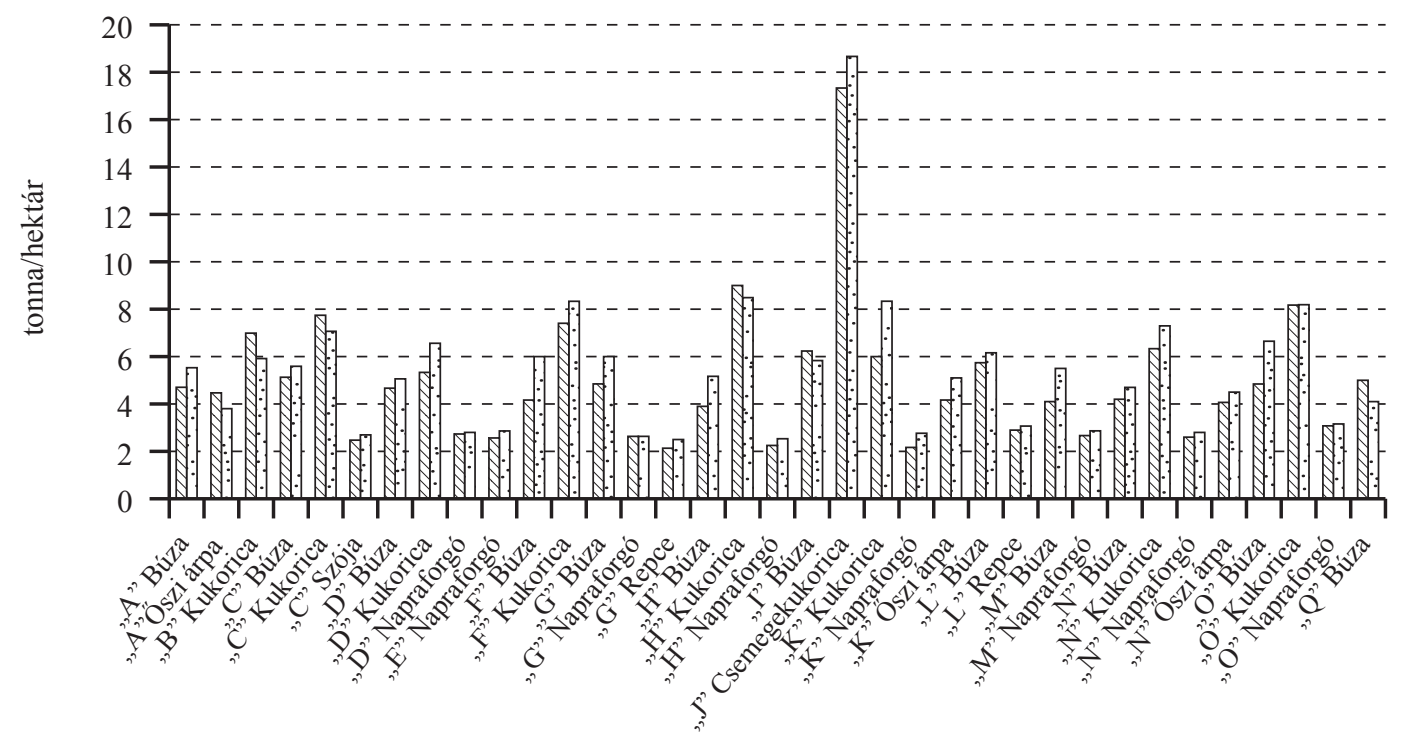

MV Precíziós gazdálkodás bevezetése előtt $\quad \because$ Precíziós gazdálkodás bevezetése után

Forrás: Ágazati költség- és jövedelemelszámolási adatok alapján készült az AKI Horizontális Elemzési Osztályán

29. ábra: Vetőmagköltség a precíziós technológia alkalmazása előtti és az alkalmazást követő 3 év átlagában

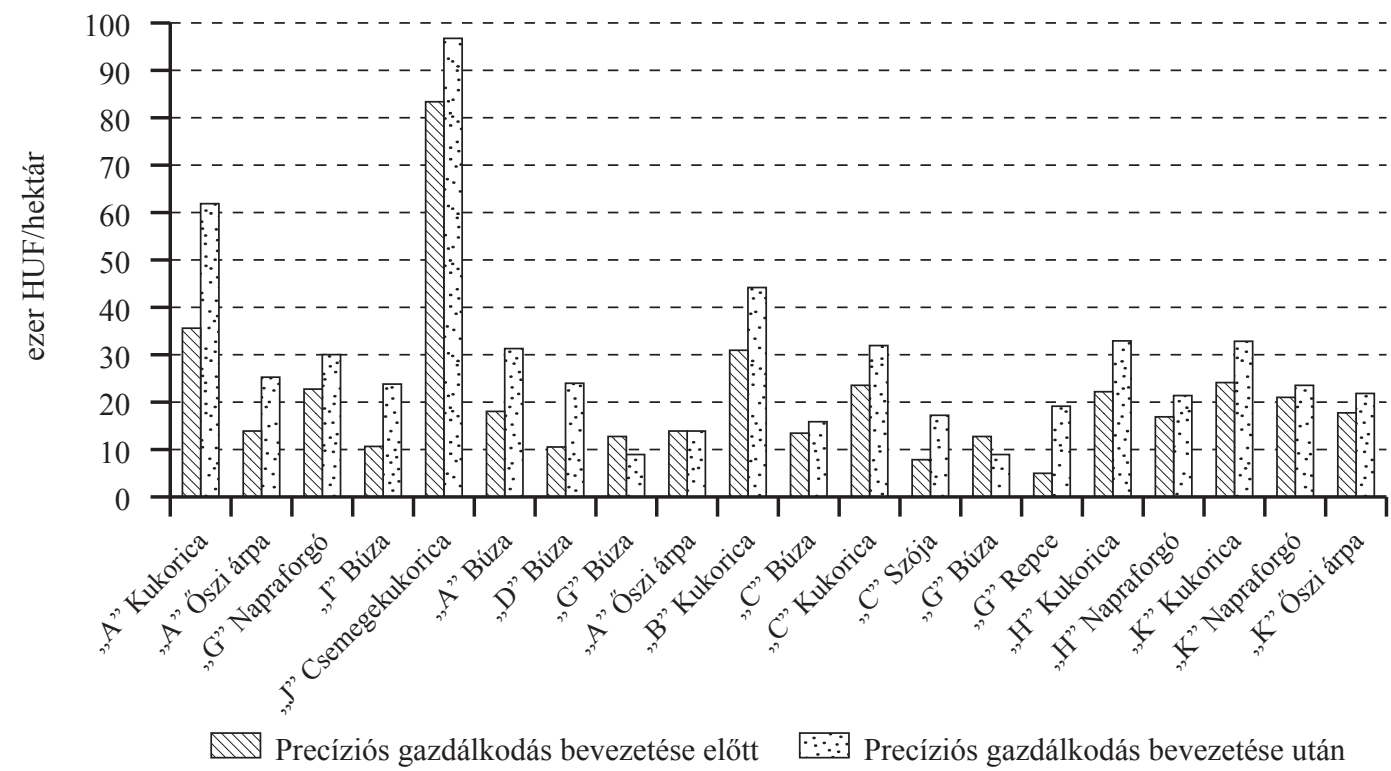

Forrás: Ágazati költség- és jövedelemelszámolási adatok alapján készült az AKI Horizontális Elemzési Osztályán

A fentiekben már említésre került, hogy a 17 üzemből 12 magas szinten mủveli a technológiát, azaz menedzsmentzónákra osztja a tábláit annak megfelelően, hogy milyen adottságokkal rendelkeznek az egyes területek, majd a tulajdonságokhoz mérten juttatja ki az inputanyagokat. Attól függően 
viszont, hogy a gazdaságok mely növénytermesztési fázisban alkalmazzák a technológiát, eltérnek az elemszámok a 12 üzem körében. A növényvédelmet majdnem minden magas technológiai színvonalat képviselő gazdaság precíziósan végzi (11 gazdaság), emellett a tápanyag-utánpótlásban 8 üzem, a vetésben pedig 9 gazdaság alkalmazta azt. A továbbiakban a növényvédelmet helyspecifikusan megvalósító üzemeknél a növényvédőszer-költség, a tápanyag-utánpótlás esetén a mütrágyamennyiség, a precíziós vetésnél pedig a vetőmagköltség kerül elemzésre.

A vetés során sorművelést alkalmazó és tőszámot változtató 9 üzem a precíziós technológia bevezetése elött átlagosan 56 százalékkal kevesebbet fordított vetőmagra és mindössze 3 gazdaság csökkentette a vetőmagköltségét a precíziós gazdálkodás során, azaz a technológia vetőmagköltségcsökkentő hatását nem sikerült igazolni (29. ábra). A vetőmag-ráfordítás növelése főként abból adódik, hogy a gazdaságok jobb minőségü vetőmagot vásároltak. A vetőmag mennyiségének változását erre vonatkozó adatok hiányában nem tudtuk vizsgálni.

A precíziós gazdaságok között 10 üzem helyspecifikusan valósította meg a talaj tápanyag-utánpótlását. Ezen üzemeknél az adatbázis lehetőséget biztosított a kijuttatott mütrágya mennyiségének vizsgálatára is, amely a költségadatoknál pontosabban tükrözi a technológia mütrágya-felhasználásra gyakorolt hatását, még akkor is, ha a ráfordítás korrigálásra került az áringadozással. A technológia átvétele, ahogy az a fentiekben már említésre került, egyes üzemeknél jellemzően nem jár az inputanyag-mennyiség mérséklésével, hiszen előfordulhat, hogy a gazdálkodó a szükségesnél kevesebb mütrágyát szórt ki a technológia bevezetése előtt a területére, erre azonban fény derül a talajminta-vételezés során. Abban az esetben javasolt a mennyiség növelése, amennyiben a hozamok kompenzálni képesek a megnövekedett költséget. A tíz üzem átlagosan 4,7 százalékkal növelte a kijuttatott mütrágya mennyiségét a technológia bevezetését követően (30. ábra).

\section{0. ábra: Kijuttatott mütrágya mennyiségének alakulása a precíziós üzemeknél a technológia bevezetése előtti és az alkalmazást követő 3 év átlagában}

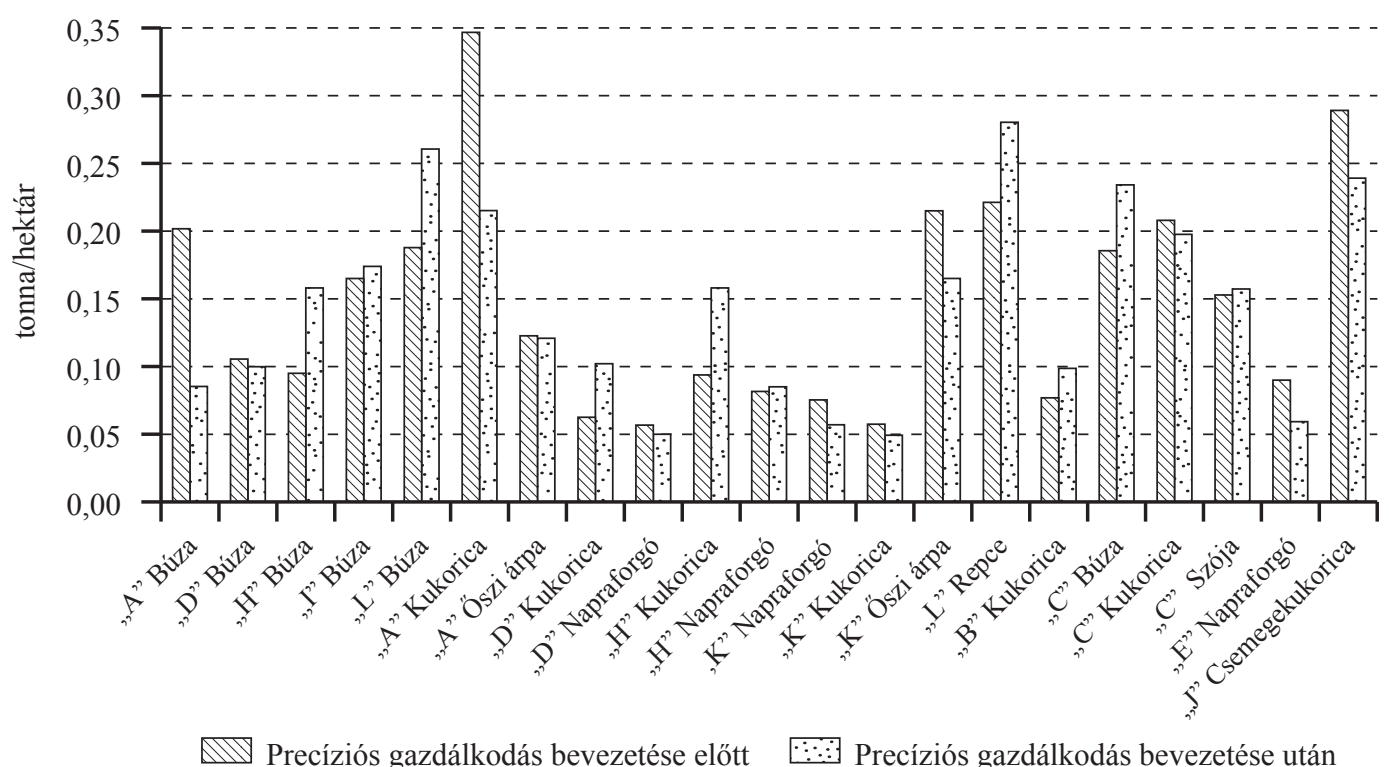

Forrás: Ágazati költség- és jövedelemelszámolási adatok alapján készült az AKI Horizontális Elemzési Osztályán

A tíz üzem precíziósan termesztett növénykultúráiban a 21 esetböl összesen 11 alkalommal kevesebb volt a mütrágya-felhasználás mértéke, vagyis az üzemek fele a kijuttatott mütrágya mennyiségét csökkentette (30. ábra). Nem meglepő módon azok az üzemek mérsékelték a felhasznált mennyisé- 
get, amelyek a technológia alkalmazása előtt jelentős mennyiségủ műtrágyát szórtak ki, azaz náluk a mennyiségi csökkentés a gazdaságosság szempontjából is szükségszerü volt.

A vizsgált precíziós gazdaságok növényvédőszer-költsége szintén emelkedett a technológia bevezetése előtti három év középértékéhez képest átlagosan 37,2 százalékkal. A kijuttatott mütrágyától eltérően a növényvédő szer mennyiségére vonatkozóan nem állt rendelkezésre adat. A költségnövekedést befolyásolja, hogy a gazdaságok zöme talajkímélő müvelést is végez a precíziós tevékenység mellett, amely magasabb növényvédőszer-mennyiség felhasználását eredményezi, vagyis a növényvédőszer-költség növekedésének fő mozgatórugója a talajkímélő gazdálkodásra való áttérés. Az üzemek számottevő része minden precíziósan termesztett növénykultúrában növelte a növényvédő szerre fordított költségét. Mindösszesen 4 gazdaság növényvédőszer-ráfordítása csökkent a helyspecifikusan müvelt növényeik közül egyetlen kultúra esetében (31. ábra).

\section{1. ábra: Növényvédőszer-költség alakulása a precíziós üzemeknél a technológia bevezetése előtti és az alkalmazást követő 3 év átlagában}

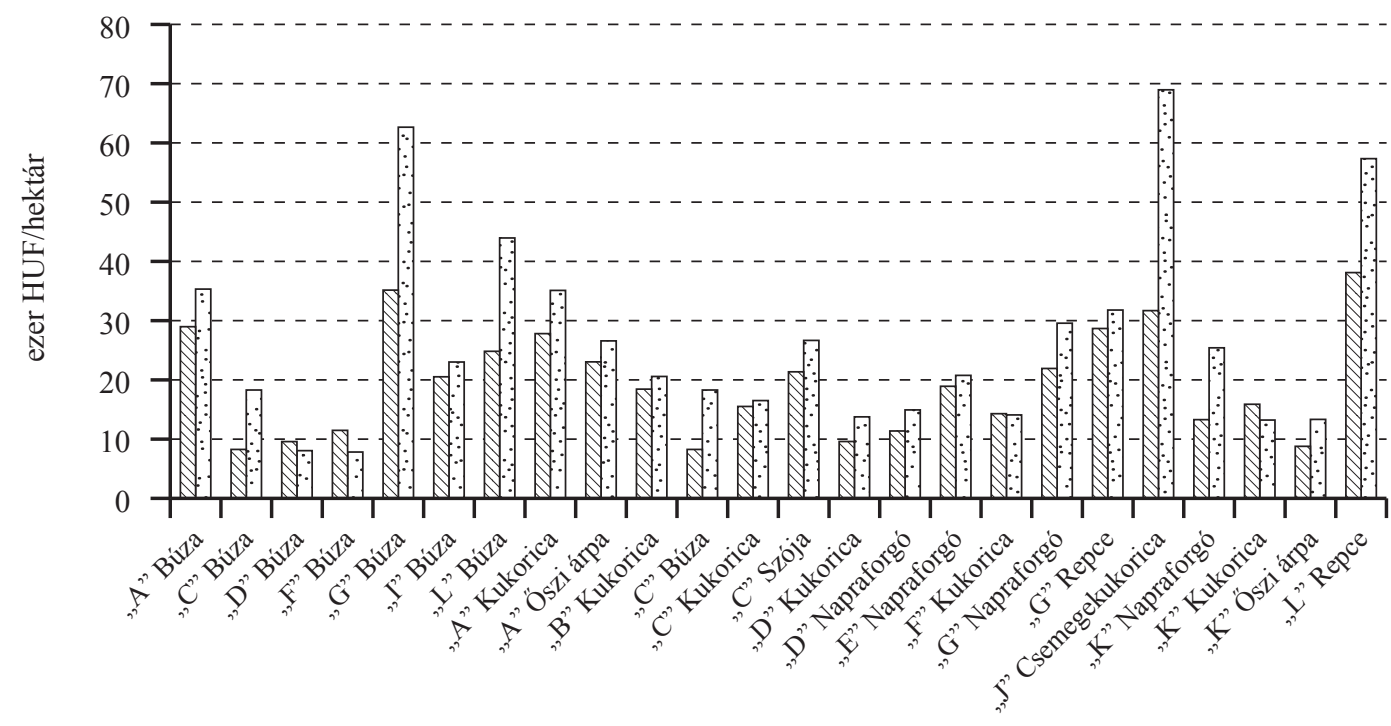

Precíziós gazdálkodás bevezetése előtt

Forrás: Ágazati költség- és jövedelemelszámolási adatok alapján készült az AKI Horizontális Elemzési Osztályán

Összességében elmondható, hogy a vizsgált üzemeknél a technológia nem csökkentette a termelés ráfordításait, viszont nagymértékben növelte a hozamokat, ami a költségek emelkedéséhez képest magasabb termelési értéket eredményezett. Az eredmények növekedése ágazati szinten a növények mintegy 66 százalékánál volt megfigyelhető. Ezzel szemben az egységnyi költséggel elóállított termelési érték már kevésbé alakult kedvezően, ágazati szinten 48,6 százalékot tett ki azon növények száma, amelyek termesztése során a precíziós technológia bevezetése egyértelmüen növelte a ráfordításokkal elérhető termelési értéket. 



\section{A precíziós gazdálkodás becsült makrogazdasági hatásai}

Az eddig bemutatott szakirodalmakból és saját számításainból egyértelmüen kiderült, hogy a precíziós technológia egyaránt hatással van a hozamokra, a termelési értékre, a termelési költségre, az önköltségre és az ágazati eredményre. Hogy ez a hatás pontosan mekkora, abban már kisebbnagyobb eltéréseket jeleznek a különböző információs források. A fejezet első részében áttekintjük az előbbiekben felsorolt tényezőket, hogy rendszerezzük és összegezzük az eddig bemutatott számítási eredményeket, valamint hogy behatároljuk a precíziós technológia által elérhető különbséget az egyes növénykultúráknál a hagyományos üzemekhez képest. Amint azt korábban már több helyen leírtuk, a precíziós technológia bevezetése által elérhető többlet nagyban függ az adott gazdaság adottságaitól. Ezt a bizonytalanságot a fejezet második részében úgy kívánjuk számszerüsíteni, hogy a számítások során a korábban üzemszinten kimutatott minimális és maximális értékek alapján végezzük el a becsléseket.

\subsection{A precíziós gazdálkodást folytató üzemek és a kontrollcsoport vizsgálatának eredményei}

Első lépésben a hozam tekintetében a gazdák által érzékelt hatásokat összesítettük. Mivel kérdéseink során nem kötöttük időszakhoz a hatásra adott válaszokat, ezért alapvetően azt feltételezzük, hogy a válaszokban az áttérés utáni átlagos értékek jelennek meg. Ugyanakkor a technológiát rövidebb ideje alkalmazók esetében még torzíthatják a képet az áttéréshez kapcsolódó nehézségek. A kérdőívekre adott válaszok alapján megállapítottuk, hogy a napraforgó kivételével valamennyi növénykultúránál 5-15 százalékos hozamemelkedést tapasztalnak a megkérdezettek. A napraforgónál ez az intervallum az 5 százalékos hozamcsökkenéstől a 15 százalékos hozamnövekedésig terjed.

A KITE Zrt. adatai ugyancsak hozamnövekedést számszerüsítenek a precíziós tecnológia bevezetésének hatására. A legnagyobb mértékü többlet az őszi káposztarepce és őszi árpa esetében (+5 százalék) jelentkezett, de a kukorica és a búza is mindössze 1, illetve 2 százalékponttal marad el az előbbiektöl.

16. táblázat: A precíziós gazdálkodás hozamra gyakorolt hatása

százalék

\begin{tabular}{|c|c|c|c|c|c|c|c|c|c|}
\hline \multirow[b]{2}{*}{ Növény } & \multirow[b]{2}{*}{ Hipotézis } & \multirow{2}{*}{$\begin{array}{c}\text { Kérdőív } \\
\text { alapján }\end{array}$} & \multirow{2}{*}{$\begin{array}{l}\text { KITE } \\
\text { Zrt. } \\
\text { adatai }\end{array}$} & \multicolumn{3}{|c|}{$\begin{array}{c}\text { Kontrollcsoporthoz } \\
\text { viszonyítva }\end{array}$} & \multirow{2}{*}{$\begin{array}{c}\begin{array}{c}\text { Üzemen } \\
\text { belül }\end{array} \\
17 \text { üzem } \\
\text { (3 precízi- } \\
\text { ós előtti, } \\
3 \text { utáni év) }\end{array}$} & \multicolumn{2}{|c|}{$\begin{array}{c}\text { Eltérés } \\
\text { a számítások } \\
\text { alapján }\end{array}$} \\
\hline & & & & $\begin{array}{c}45 \\
\text { üzem } \\
(1 \text { év) }\end{array}$ & $\begin{array}{c}17 \\
\text { üzem } \\
\text { (3 év) }\end{array}$ & $\begin{array}{l}17 \text { üzem } \\
\text { (3 év, kont- } \\
\text { rollcsoport- } \\
\text { szúkítés) }\end{array}$ & & $\begin{array}{l}\text { Mini- } \\
\text { mum }\end{array}$ & $\begin{array}{l}\text { Maxi- } \\
\text { mum }\end{array}$ \\
\hline Öszi búza & Nagyobb & $+5-+15$ & +3 & +7 & +17 & +14 & +17 & +7 & +17 \\
\hline Kukorica & Nagyobb & $+5-+15$ & +4 & +9 & +2 & +2 & +8 & +2 & +9 \\
\hline Napraforgó & Nagyobb & $-5-+15$ & +5 & +10 & +6 & +9 & +9 & +6 & +10 \\
\hline $\begin{array}{l}\text { Öszi } \\
\text { káposztarepce }\end{array}$ & Nagyobb & $+5-+15$ & +5 & +11 & - & - & - & - & - \\
\hline Öszi árpa & Nagyobb & $+5-+15$ & - & +5 & - & - & - & - & - \\
\hline
\end{tabular}

Megjegyzés: Nem egyértelmüen igazolható, _ Számításokkal igazolható, _ Statisztikailag igazolható.

Forrás: A KITE Zrt. adatai, a kérdőíves értékek és az FADN-adatok alapján készült az AKI Horizontális Elemzési Osztályán 
Az általunk végzett vizsgálatok közül háromnál a kontrollcsoport (lásd 4. fejezet módszertan) értékeit vetettük össze a 2015. évtől precíziósan gazdálkodók hozamadataival (45, illetve 17 üzem). A precíziósan gazdálkodó üzemek esetében a hozamnövekedés minden növénynél meghaladta az 5 százalékot, legmagasabb értéke az őszi káposztarepcénél volt 11 százalékkal.

Annál a 17 üzemnél, akik legalább három éve áttértek a precíziós gazdálkodásra, a váltás után a kontrollcsoporthoz képest 17 százalékos többlet keletkezett a búzánál, 2-6 százalékos bővülés pedig a kukorica és napraforgó esetében. ${ }^{4}$ Az eredmények statisztikai módszerekkel is igazolhatók voltak. Ezeknél az üzemeknél a technológiai váltás miatt fellépő különbségek markánsabb kidomborítása érdekében tovább szigorítottuk a kontrollcsoport kiválasztásának feltételeit (lásd 4. fejezet). Ennek eredményeként a kimutatható különbségek erősödtek, a 17 üzem hozamértékei 2-14 százalékkal múlták felül a kontrollcsoport hozamértékeit az egyes szántóföldi növények esetében.

A vizsgálat utolsó lépésében azt elemeztük, hogy az üzemek hozameredményei önmagukhoz képest is javultak-e a precíziós technológiára való áttérés hatására, amihez az üzemek precíziós gazdálkodás elötti és utáni hároméves hozamértékeit vetettük össze. A hipotézis ez esetben is igaznak bizonyult, ugyanis búza esetében 17, kukoricánál és napraforgónál 8-9 százalékos hozamemelkedés igazolódott.

Összességében a minimum- és maximumértékeket nézve megállapítható, hogy a precíziós gazdálkodást végzők körében a búzánál 7-17 százalékban, a kukoricánál 2-9 százalékban, a napraforgónál 6-10 százalékban emelkedtek meg a hozamok (16. táblázat) a precíziós technológiát alkalmazók körében.

Az eredmények összegzését a termelési értéknél is elvégeztük. A 17. táblázatban jól látható, hogy a termelési értékek valamennyi információs forrás szerint egyértelmủen nőttek. A gazdák várakozásai szerint a termelési érték a precíziós technológiát alkalmazók körében 5-15 százalékkal növekedhet mind az öt nagy szántóföldi kultúránál. A KITE Zrt. adatai szerint a precíziós gazdálkodás hatása a búzatermesztésnél 3 százalékos termelésiérték-növekedést jelent a hagyományos gazdálkodással szemben. A kukoricánál, a napraforgónál és az őszi káposztarepcénél ez az eltérés 4 százalék volt.

\section{7. táblázat: A precíziós gazdálkodás termelési értékre gyakorolt hatása}

\begin{tabular}{|c|c|c|c|c|c|c|c|c|c|}
\hline \multirow[b]{2}{*}{ Növény } & \multirow[b]{2}{*}{ Hipotézis } & \multirow{2}{*}{$\begin{array}{c}\text { Kérdőív } \\
\text { alapján }\end{array}$} & \multirow{2}{*}{$\begin{array}{c}\text { KITE } \\
\text { Zrt. } \\
\text { adatai }\end{array}$} & \multicolumn{3}{|c|}{$\begin{array}{l}\text { Kontrollcsoporthoz } \\
\text { viszonyítva }\end{array}$} & \multirow{2}{*}{$\begin{array}{c}\begin{array}{c}\text { Üzemen } \\
\text { belül }\end{array} \\
17 \text { üzem } \\
\text { (3 precízi- } \\
\text { ós elötti, } \\
3 \text { utáni év) }\end{array}$} & \multicolumn{2}{|c|}{$\begin{array}{c}\text { Eltérés } \\
\text { a számítások } \\
\text { alapján }\end{array}$} \\
\hline & & & & $\begin{array}{c}45 \\
\text { üzem } \\
(1 \text { év) }\end{array}$ & $\begin{array}{c}17 \\
\text { üzem } \\
\text { (3 év) }\end{array}$ & $\begin{array}{l}17 \text { üzem } \\
\text { (3 év, kont- } \\
\text { rollcsoport- } \\
\text { szúkítés) }\end{array}$ & & $\begin{array}{l}\text { Mini- } \\
\text { mum }\end{array}$ & $\begin{array}{l}\text { Maxi- } \\
\text { mum }\end{array}$ \\
\hline Öszi búza & Nagyobb & $+5-+15$ & +3 & +13 & +10 & +8 & +38 & +8 & +38 \\
\hline Kukorica & Nagyobb & $+5-+15$ & +4 & +16 & +11 & +13 & +42 & +11 & +42 \\
\hline Napraforgó & Nagyobb & $+5-+15$ & +4 & +11 & +3 & +7 & +32 & +3 & +32 \\
\hline $\begin{array}{l}\text { Öszi } \\
\text { káposztarepce }\end{array}$ & Nagyobb & $+5-+15$ & +4 & +24 & - & - & - & - & - \\
\hline Öszi árpa & Nagyobb & $+5-+15$ & - & +13 & - & - & - & - & - \\
\hline
\end{tabular}

Megjegyzés: Számításokkal igazolható, Statisztikailag igazolható.

Forrás: A KITE Zrt. adatai, a kérdőíves értékek és az FADN-adatok alapján készült az AKI Horizontális Elemzési Osztályán

\footnotetext{
Az őszi káposztarepcére és az őszi árpára az üzemek nem rendelkeztek elegendő adattal a számításhoz.
} 
Annál a 45 üzemnél, amely legalább egy éve végez precíziós gazdálkodást, a búza, a kukorica, a napraforgó és az őszi árpa termelési értéke 11-16 százalékkal volt magasabb, mint a hagyományos üzemeknél. A termelési értéknél jelentkező többlet az őszi káposztarepcénél volt a legmagasabb arányú, 24 százalék a viszonyítási alaphoz képest. A három éve precíziós gazdálkodást végzőknél a termelési érték búzánál 10, kukoricánál 11 és napraforgónál 3 százalékkal nőtt a kontrollcsoporthoz viszonyítva. Ugyanezen üzemek előnye mind a szükített kontrollcsoporthoz képest, mind pedig a három éve precíziós gazdálkodást folytatókhoz mérten jelentősen nagyobbnak bizonyult. A kukorica és a napraforgó esetében 7-13 százalékos statisztikailag is igazolható növekedés mutatható ki, búzánál a precíziós gazdálkodás 8 százalékos termelésiérték-többletet jelentett.

A precíziós gazdálkodást folytató üzemek termelési értékei önmagukhoz képest is javultak, a búza esetében 38, a kukoricánál 42 és a napraforgónál 32 százalékos termelésiérték-emelkedés igazolódott.

Összességében a minimum- és maximumértékeket nézve megállapítható, hogy a precíziós gazdálkodást végzők körében a búzánál 8-38 százalékkal, a kukoricánál 11-42 százalékkal, a napraforgónál 3-32 százalékkal nőtt a termelési érték (17. táblázat).

Hipotézisünk szerint a precíziós gazdálkodást folytató üzemeknél a termelési költség alacsonyabb, mint a hagyományos termesztési technológiát alkalmazóknál. A 18. táblázatból leolvasható, hogy ez a feltételezés a legtöbb esetben igazolást nyert.

A gazdák várakozásai szerint a precíziós technológia alkalmazása a termelési költségben 5-15 százalékos csökkenést jelent az egyes növénykultúráknál, kivéve a napraforgót. A KITE Zrt. tapasztalati eredményei szerint a precíziós gazdálkodás bevezetése a búza és a napraforgó termesztésénél 3 százalékos termelési költségelőnnyel bír a hagyományos gazdálkodáshoz képest, kukoricánál ez az eltérés 2 százalék.

A 45 precíziós gazdálkodást folytató üzem termelési költségének kontrollcsoporthoz viszonyított alacsonyabb értékét nem tudtuk kimutatni, mivel ezeknél az üzemeknél mind az öt növény esetében 3-23 százalékos termelésiköltség-emelkedés következett be. Ez részben az intenzív gazdálkodásra való áttérés okozta magasabb inputigénynek tulajdonítható. Legnagyobb mértékben, több mint 15 százalékkal a kukorica és az őszi káposztarepce termesztőinek termelési költsége nőtt, míg a napraforgó termelési költsége változott legkevésbé (+3 százalék). A legalább három éve precíziós gazdálkodást végzőknél a termelési költség búzánál 1, kukoricánál 5 és napraforgónál 8 százalékkal maradt el a kontrollcsoporthoz viszonyítva.

\section{8. táblázat: A precíziós gazdálkodás termelési költségre gyakorolt hatása}

\begin{tabular}{|c|c|c|c|c|c|c|c|c|c|}
\hline \multirow[b]{2}{*}{ Növény } & \multirow[b]{2}{*}{ Hipotézis } & \multirow{2}{*}{$\begin{array}{c}\text { Kérdőív } \\
\text { alapján }\end{array}$} & \multirow{2}{*}{$\begin{array}{c}\text { KITE } \\
\text { Zrt. } \\
\text { adatai }\end{array}$} & \multicolumn{3}{|c|}{$\begin{array}{c}\text { Kontrollcsoporthoz viszo- } \\
\text { nyítva }\end{array}$} & \multirow{2}{*}{$\begin{array}{c}\begin{array}{c}\text { Üzemen } \\
\text { belül }\end{array} \\
17 \text { üzem } \\
\text { (3 precízi- } \\
\text { ós előtti, } \\
3 \text { utáni év) }\end{array}$} & \multicolumn{2}{|c|}{$\begin{array}{c}\text { Eltérés } \\
\text { a számítások } \\
\text { alapján }\end{array}$} \\
\hline & & & & $\begin{array}{c}45 \\
\text { üzem } \\
\text { (1 év) }\end{array}$ & $\begin{array}{c}17 \\
\text { üzem } \\
\text { (3 év) }\end{array}$ & $\begin{array}{l}17 \text { üzem } \\
\text { (3 év, kont- } \\
\text { rollcsoport- } \\
\text { szúkítés) }\end{array}$ & & $\begin{array}{l}\text { Mini- } \\
\text { mum }\end{array}$ & $\begin{array}{l}\text { Maxi- } \\
\text { mum }\end{array}$ \\
\hline Öszi búza & Kisebb & $-15--5$ & -3 & +9 & -1 & -3 & +47 & -3 & +47 \\
\hline Kukorica & Kisebb & $-15--5$ & -2 & +23 & -5 & 0 & +30 & -5 & +30 \\
\hline Napraforgó & Kisebb & $-15-+15$ & -3 & +3 & -8 & -2 & +26 & -8 & +26 \\
\hline $\begin{array}{l}\text { Öszi } \\
\text { káposztarepce }\end{array}$ & Kisebb & $<-5$ & - & +19 & - & - & - & - & - \\
\hline Öszi árpa & Kisebb & $-15--5$ & - & +9 & - & - & - & - & - \\
\hline
\end{tabular}

Megjegyzés: Nem egyértelmüen igazolható, Számításokkal igazolható, \ámításokkal nem igazolható.

Forrás: A KITE Zrt. adatai, a kérdőíves értékek és az FADN-adatok alapján készült az AKI Horizontális Elemzési Osztályán 
Ugyanezen üzemeknél a szükített kontrollcsoporthoz képest vizsgálva az eredményeket, a kukorica termelési költségében jelentős különbség nem volt kimutatható a hagyományos üzemekhez képest. Búzánál és napraforgónál a termelési költségek 2-3 százalékkal csökkentek a precíziós gazdálkodást folytatók körében.

A 18. táblázatból látható az is, hogy a precíziós gazdálkodást folytató üzemek termelési költségei önmagukhoz képest jelentősen nőttek. Búza esetében 47, a kukoricánál 30 és a napraforgónál 26 százalékos termelésiköltség-bővülés mutatható ki. Itt szintén az optimális technológiára való áttérés okán megnövekedett inputanyagköltség volt meghatározó.

Összességében a minimum- és maximumértékeket nézve megállapítható, hogy a precíziós gazdálkodást végzők körében egyértelmüen nem jelenthető ki, hogy a termelési költségek csökkennének, hiszen a búzánál -3 és +47 , a kukoricánál -5 és +30 , a napraforgónál -8 és +26 százalék között változtak a termelési költségek (18. táblázat). Azonban látható az is, hogy ha valaki extenzív technológiával gazdálkodik, akkor a termelési költségek jóval nagyobb mértékben emelkedhetnek (maximum százalékos értékek), míg az intenzív technológiát folytatóknál - növénykultúrától függően - a termelési költségek 3-8 százalékban csökkenhetnek.

Az önköltséggel kapcsolatban azzal az előfeltevéssel éltünk, hogy a precíziós gazdálkodást folytató üzemek önköltsége alacsonyabb, mint a hagyományos termesztési technológiát alkalmazóké. A 19. táblázatból leolvasható, hogy az esetek többségében ezt igazolni is tudtuk.

A kérdőíves megkérdezés nem tartalmazta az önköltségre vonatkozó kérdést. A KITE Zrt. adatai szerint a precíziós gazdálkodás a búza- és a kukoricatermesztésnél 6 százalékos önköltségcsökkenést jelent a hagyományos gazdálkodással szemben. A napraforgó és az őszi káposztarepce termesztésének önköltsége 8 százalékkal alacsonyabb, mint a hagyományos gazdaságoké.

A legalább 1 éve precíziós gazdálkodást folytató 45 üzem és a kontrollcsoport önköltségadatai között a kukoricánál nem jelentkezett különbség, búzánál és őszi árpánál azonban 6-7, őszi káposztarepcénél 1 százalékos önköltségcsökkenést lehetett kimutatni. A 19. táblázatból látható, hogy a precíziós technológiát alkalmazó üzemeknél legjobban a napraforgó önköltsége mérséklődött (-10 százalék). A három éve precíziós gazdálkodást végzőknél az önköltség búzánál és napraforgónál 17, kukoricánál 13 százalékkal csökkent a kontrollcsoporthoz viszonyítva.

19. táblázat: A precíziós gazdálkodás önköltségre gyakorolt hatása

százalék

\begin{tabular}{|c|c|c|c|c|c|c|c|c|c|}
\hline \multirow[b]{2}{*}{ Növény } & \multirow[b]{2}{*}{ Hipotézis } & \multirow{2}{*}{$\begin{array}{c}\text { Kérdőív } \\
\text { alapján }\end{array}$} & \multirow{2}{*}{$\begin{array}{c}\text { KITE } \\
\text { Zrt. } \\
\text { adatai }\end{array}$} & \multicolumn{3}{|c|}{$\begin{array}{l}\text { Kontrollcsoporthoz } \\
\text { viszonyítva }\end{array}$} & \multirow{2}{*}{$\begin{array}{c}\begin{array}{c}\text { Üzemen } \\
\text { belül }\end{array} \\
17 \text { üzem } \\
\text { (3 precízi- } \\
\text { ós előtti, } \\
3 \text { utáni év) }\end{array}$} & \multicolumn{2}{|c|}{$\begin{array}{c}\text { Eltérés } \\
\text { a számítások } \\
\text { alapján }\end{array}$} \\
\hline & & & & $\begin{array}{c}45 \\
\text { üzem } \\
\text { (1 év) }\end{array}$ & $\begin{array}{c}17 \\
\text { üzem } \\
\text { (3 év) }\end{array}$ & $\begin{array}{l}17 \text { üzem } \\
\text { (3 év, kont- } \\
\text { rollcsoport- } \\
\text { szúkítés) }\end{array}$ & & $\begin{array}{l}\text { Mini- } \\
\text { mum }\end{array}$ & $\begin{array}{l}\text { Maxi- } \\
\text { mum }\end{array}$ \\
\hline Öszi búza & Kisebb & - & -6 & -7 & -17 & -17 & +29 & -17 & +29 \\
\hline Kukorica & Kisebb & - & -6 & 0 & -13 & -8 & +22 & -13 & +22 \\
\hline Napraforgó & Kisebb & - & -8 & -10 & -17 & -14 & +20 & -17 & +20 \\
\hline $\begin{array}{l}\text { Őszi } \\
\text { káposztarepce }\end{array}$ & Kisebb & - & -8 & -1 & - & - & - & - & - \\
\hline Öszi árpa & Kisebb & - & - & -6 & - & - & - & - & - \\
\hline
\end{tabular}

Megjegyzés: Számításokkal igazolható, _ Statisztikailag igazolható, _ Számításokkal nem igazolható.

Forrás: A KITE Zrt. adatai, a kérdőíves értékek és az FADN-adatok alapján készült az AKI Horizontális Elemzési Osztályán 
A szűkített kontrollcsoporthoz képest is jelentős különbségek adódtak az önköltségben. Búzánál a precíziós gazdálkodás 17 százalékkal alacsonyabb önköltséget jelentett. A kukorica- és a napraforgótermesztők között 8-14 százalékkal mérsékeltebb önköltségértékek jelentkeztek a hagyományosan gazdálkodókkal szemben, ami statisztikailag is igazolható volt.

A precíziós gazdálkodást folytató üzemek önköltsége a technológiaváltást követően nőtt. Ennek oka leginkább az lehet, hogy e gazdaságok korábban is extenzíven gazdálkodtak. A precíziós gazdálkodásra való áttérés intenzív gazdálkodást hozott, ami az inputanyagköltségeket, így az önköltséget is megemelte. Búza esetében 29, a kukoricánál 22 és a napraforgónál 20 százalékos önköltségemelkedés történt, vagyis ebben az esetben a hipotézisünk nem igazolódott.

Összességében a minimum- és maximumértékeket nézve megállapítható, hogy a precíziós gazdálkodást végzők körében az önköltség búzánál és napraforgónál akár 17 százalékkal, kukoricánál akár 13 százalékkal csökkenhet, de növekedhet is 20-29 százalékkal.

Hipotézisünk alapján azt vártuk, hogy vizsgálataink a precíziós gazdálkodást folytató üzemek esetében magasabb ágazati eredményt igazolnak a hagyományos termesztési technológiát alkalmazókhoz képest. A 20. táblázatból leolvasható, hogy ez a várakozásunk a legtöbb esetben teljesült. Ráadásul az is megállapítható, hogy a korábbi tényezőkhöz képest az ágazati eredményeknél jelentkezik százalékosan a legnagyobb előny.

A kérdőíves felmérésben nem tértünk ki az ágazati eredmény kérdésére. A KITE Zrt. adatai szerint a precíziós gazdálkodás búza esetében 42, kukoricánál 27, napraforgónál 50 és őszi káposztarepcénél 44 százalékos többletet jelent az ágazati eredményben. A 45 precíziós gazdálkodást folytató üzem eredményei a kontrollcsoporthoz viszonyítva egyedül a kukorica esetében csökkentek (-17 százalék). Búzánál és napraforgónál a precíziós üzemek 23-28 százalékkal, míg az őszi káposztarepcénél és az őszi árpánál 30-40 százalékkal realizáltak magasabb ágazati eredményt.

\section{0. táblázat: A precíziós gazdálkodás ágazati eredményre gyakorolt hatása}

százalék

\begin{tabular}{|c|c|c|c|c|c|c|c|c|c|}
\hline \multirow[b]{2}{*}{ Növény } & \multirow[b]{2}{*}{ Hipotézis } & \multirow{2}{*}{$\begin{array}{c}\text { Kérdőív } \\
\text { alapján }\end{array}$} & \multirow{2}{*}{$\begin{array}{c}\text { KITE } \\
\text { Zrt. } \\
\text { adatai }\end{array}$} & \multicolumn{3}{|c|}{$\begin{array}{c}\text { Kontrollesoporthoz viszo- } \\
\text { nyítva }\end{array}$} & \multirow{2}{*}{$\begin{array}{c}\begin{array}{c}\text { Üzemen } \\
\text { belül }\end{array} \\
17 \text { üzem } \\
\text { (3 precízi- } \\
\text { ós előtti, } \\
3 \text { utáni év) }\end{array}$} & \multicolumn{2}{|c|}{$\begin{array}{c}\text { Eltérés } \\
\text { a számítások } \\
\text { alapján }\end{array}$} \\
\hline & & & & $\begin{array}{c}45 \\
\text { üzem } \\
(1 \text { év })\end{array}$ & $\begin{array}{c}17 \\
\text { üzem } \\
(3 \text { év) }\end{array}$ & $\begin{array}{l}17 \text { üzem } \\
\text { (3 év, kont- } \\
\text { rollcsoport- } \\
\text { szúkítés) }\end{array}$ & & $\begin{array}{l}\text { Mini- } \\
\text { mum }\end{array}$ & $\begin{array}{l}\text { Maxi- } \\
\text { mum }\end{array}$ \\
\hline$\overline{\text { Búza }}$ & Kisebb & - & +42 & +23 & +44 & +43 & +133 & +23 & +133 \\
\hline Kukorica & Kisebb & - & +27 & -17 & +59 & +44 & +105 & -17 & +105 \\
\hline Napraforgó & Kisebb & - & +50 & +28 & +34 & +29 & +52 & +28 & +52 \\
\hline $\begin{array}{l}\text { Öszi } \\
\text { káposztarepce }\end{array}$ & Kisebb & - & +44 & +40 & - & - & - & - & - \\
\hline Öszi árpa & Kisebb & - & - & +30 & - & - & - & - & - \\
\hline
\end{tabular}

Megjegyzés: Számításokkal igazolható, _ Statisztikailag igazolható, — Számításokkal nem igazolható.

Forrás: A KITE Zrt. adatai, a kérdőíves értékek és az FADN-adatok alapján készült az AKI Horizontális Elemzési Osztályán

A három éve precíziós gazdálkodást végző 17 üzemnél az ágazati eredmény búzánál 44, kukoricánál 59 és napraforgónál 34 százalékkal nőtt a kontrollcsoporthoz képest. A szükített kontrollcsoporthoz viszonyítva a kukorica és a búza ágazati eredménye 43-44 százalékkal meghaladta a hagyományos üzemekét, ami kukorica esetében statisztikailag is igazolható volt. Napraforgónál az ágazati eredménytöbblet 29 százalék volt a kontrollcsoporthoz viszonyítva. 
A 20. táblázatból leolvasható az is, hogy a precíziós gazdálkodásra áttért üzemek ágazati eredménye önmagukhoz képest megtöbbszöröződött. Búza esetében 133, a kukoricánál 105 és a napraforgónál 52 százalékos ágazatieredmény-növekedés volt kimutatható.

Összességében a minimum- és maximumértékeket nézve megállapítható, hogy a precíziós gazdálkodást végzők körében a kukoricatermesztés kivételével az ágazati eredmények emelkedtek, azaz búzánál 23-133 százalékban, napraforgónál pedig 28-52 százalékban növekedtek az ágazati eredmények (20. táblázat).

\subsection{A precíziós gazdálkodás hatásai ágazati szinten}

A fejezet második részében azt vizsgáljuk meg, hogy ha az üzemek egy csoportja - amelyekre igazolni tudtuk a technológia hatásait - áttérne a precíziós gazdálkodásra, akkor ágazati szinten hogyan változnának meg a gazdálkodást jellemző mutatók (hozamok, ágazati eredmény, termelési érték, termelési költség, valamint a vetőmag-, mütrágya- és növényvédőszer-költség). Az eredményekhez tartozó alapadatok a 10-18. mellékletekben kaptak helyet.

A 4.3 alfejezetben leírtak alapján és a tesztüzemi adatok szerint a precíziós technológiára való áttérés a búzánál 7130, a kukoricánál 6601, a napraforgónál 5273, az árpánál 2131, a repcénél 338 gazdaságot érint. Az összes üzemet tekintve ez búzánál a gazdaságok 20 százalékát, kukoricánál 13 százalékát, napraforgónál 24 százalékát, őszi árpánál 16 százalékát, őszi káposztarepcénél pedig kevesebb mint 10 százalékát jelentené (32. ábra).

\section{2. ábra: Precíziós és nem precíziós üzemek aránya a technológiai váltás után}

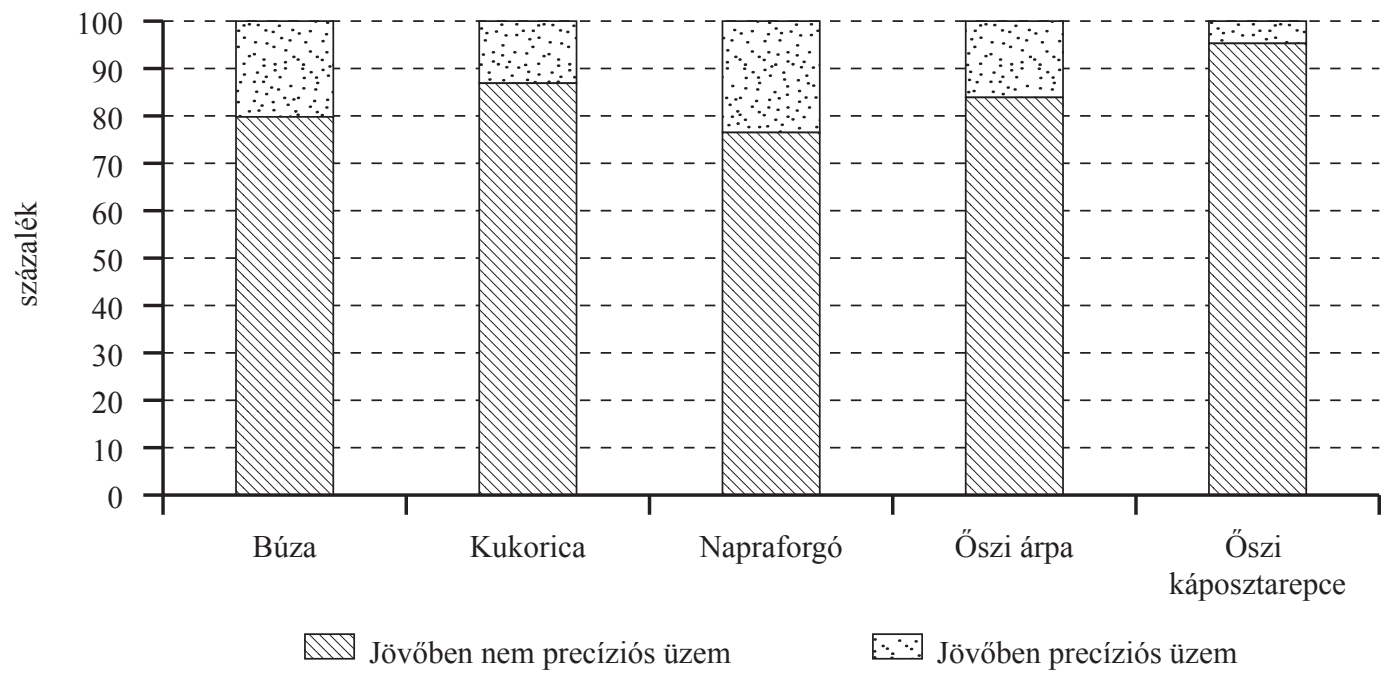

Forrás: Az AKI Horizontális Elemzési Osztályán készült számítások

Amennyiben az általunk kiválasztott, a becslés alapjául szolgáló üzemcsoport áttérne a precíziós gazdálkodásra, akkor a búza esetében a precíziós területek a teljes (937 ezer hektár 2015-ben) búzatermő terület 59,0 százalékát (553 ezer hektár), a kukoricánál a teljes (933 ezer hektár) kukoricatermő terület 39,8 százalékát (371 ezer hektár), a napraforgónál a teljes (585 ezer hektár) napraforgó-terület 58,4 százalékát (341 ezer hektár) tennék ki. Az őszi árpa és őszi káposztarepce precíziós technológiával müvelt területe (93 ezer hektár) külön-külön 19-23 százalékát adná a két ágazat összes vetésterületének (33. ábra). 
33. ábra: A vetésterület megoszlása a vizsgált üzemek precíziós gazdálkodásra való áttérése esetén

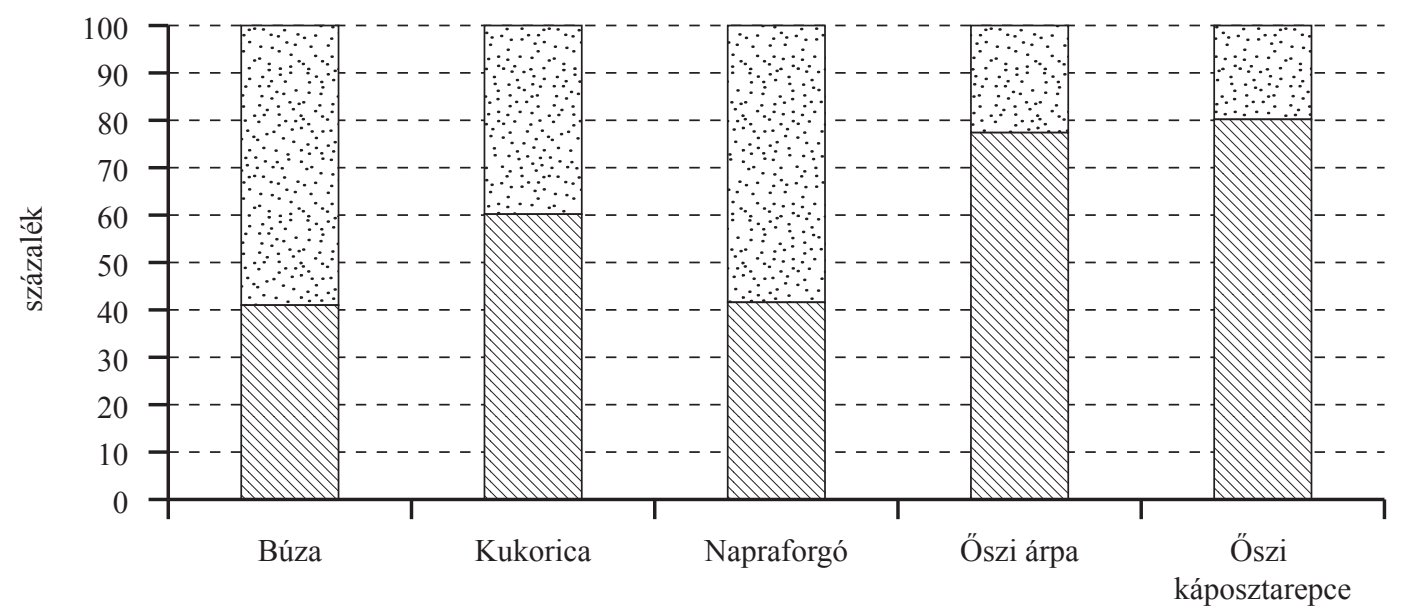

MV Jövőben nem precíziós terület

Forrás: Az AKI Horizontális Elemzési Osztályán készült számítások

\section{4. ábra: A termésmennyiség változása a precíziós gazdálkodásra való áttérés hatására}

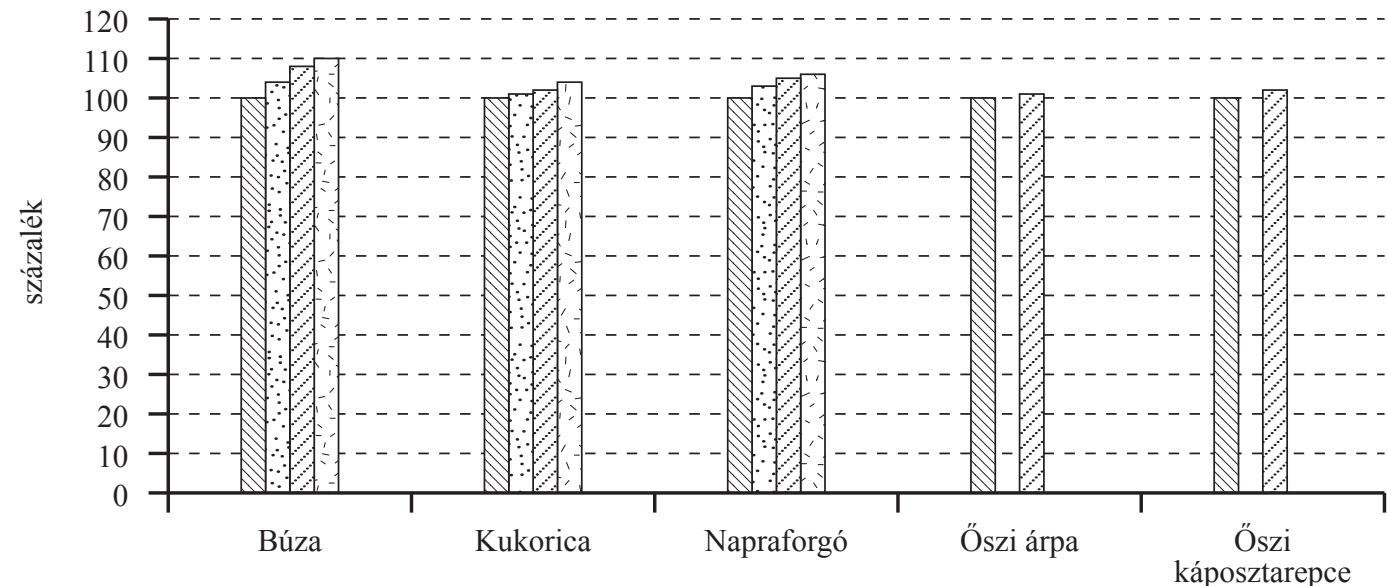

Termésmennyiség precíziós technológia nélkül

Termésmennyiség a precíziós technológia bevezetésével, minimumszorzó használatával

Termésmennyiség a precíziós technológia bevezetésével, átlagos szorzó használatával

i. Termésmennyiség a precíziós technológia bevezetésével, maximumszorzó használatával

Forrás: Az AKI Horizontális Elemzési Osztályán készült számítások

A termésmennyiséget elemezve megállapítható, hogy a kiválasztott üzemek precíziós gazdálkodásra való áttérése hatására búzánál 4-10 százalékos, azaz minimálisan 212,4 ezer tonna, maximálisan 515,9 ezer tonna termésmennyiség-bővülésre lehet számítani országos szinten. Kukoricánál 1-4 százalékkal, vagyis minimálisan 50,7 és maximálisan 228,2 ezer tonnával növekedne a termés. Napraforgónál átlagosan 5 százalékos hozamnövekedés lenne realizálható, ami a termésmennyiséget nézve 53,0-88,3 ezer tonnás emelkedést jelenthet makroszinten. Öszi árpánál 11,8, őszi káposztarep- 
cénél 14,7 ezer tonna termésnövekedés keletkezhet, ami országosan 1-2 százalékkal haladja meg az egyébként elérhető hozamokat (34. ábra).

A makroszintủ termelési érték a technológiaváltás hatására a búzánál 5-23 százalékkal, azaz minimálisan 12,0 milliárd forinttal, maximálisan pedig 56,9 milliárd forinttal emelkedhet. Kukoricánál ez 5-18 százalékos bővülést, azaz 12,1-46,1 milliárd forint többletet jelenthet. Napraforgónál 2-18 százalék, minimálisan 3,0 és maximálisan 31,6 milliárd forintnyi termelésiérték-emelkedés várható. Öszi árpánál és őszi káposztarepcénél a precíziós gazdálkodásra való áttérés a 3-5 százalékos növekedés mellett 1,3-3,7 milliárd forint közötti gyarapodást hozhat országosan (35. ábra).

\section{5. ábra: A termelési érték változása a precíziós gazdálkodásra való áttérés hatására}

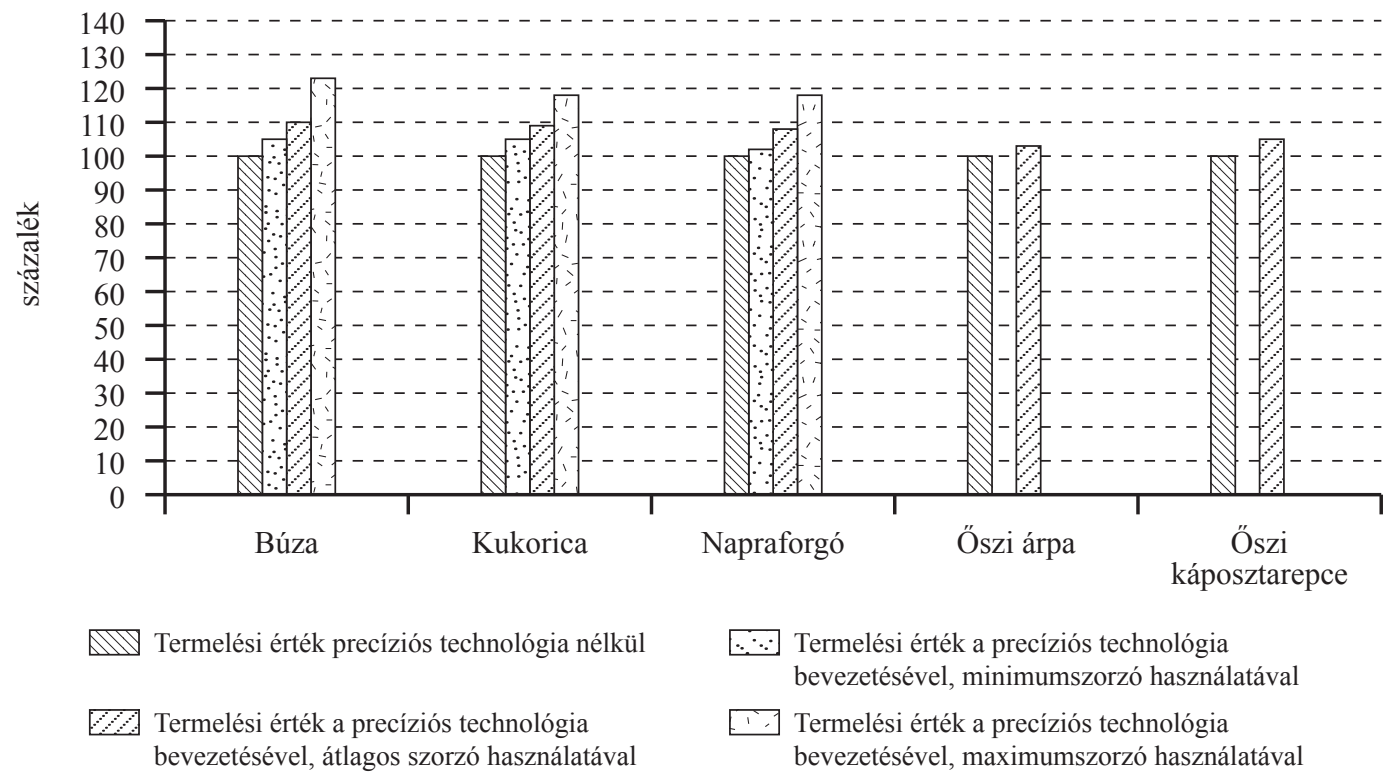

Forrás: Az AKI Horizontális Elemzési Osztályán készült számítások

A precíziós gazdálkodás hatására - abban az esetben, ha a gazdálkodó már intenzív technológiát alkalmaz - búzánál, kukoricánál és napraforgónál 2-5 százalékos, vagyis mintegy 3,3-5,7 milliárd forint termelésiköltség-csökkenés érhető el országos szinten. Az extenzív technológiáról való áttérés után kezdetben 13-28 százalék, azaz 18,6-51,5 milliárd forint termelésiköltség-emelkedés várható összességében a fentebb említett három növény esetében. Számításaink szerint az extenzív technológiáról a precíziós gazdálkodásra való áttérés búza esetében növeli meg a legjobban a termelési költségeket (+51,5 milliárd forint) és napraforgónál a legkevésbé (18,6 milliárd forint). Öszi árpánál 2 százalékos ( $+0,7$ milliárd forint), őszi káposztarepcénél 5 százalékos ( $+2,5$ milliárd forint) emelkedéssel lehet számolni (36. ábra).

A precíziós gazdálkodásra való áttérés országosan 14-80 százalékban növelné a búzatermesztők ágazati eredményét, azaz minimálisan 9,2 milliárd forinttal, maximálisan pedig 53,5 milliárd forinttal bővülne az ágazati eredmény a precíziós gazdálkodásra való áttérés esetében. Ugyanez napraforgónál 14-27 százalékkal (+7,6-14,0 milliárd forint) növelné, őszi árpánál és őszi káposztarepcénél 4-8 százalékkal (+0,6-0,9 milliárd forint) emelné az országos ágazati eredményt a precíziós technológiára történő áttérés után. Figyelemreméltó, hogy kukorica esetében nem ilyen kedvező a kép, hiszen az ágazati eredmény 3,1 milliárd forinttal maradhat el, de akár 19,2 milliárd forinttal (8-47 százalék) növekedhet is a nem precíziósan gazdálkodók ágazati eredményéhez képest (37. ábra). 
36. ábra: A termelési költség változása a precíziós gazdálkodásra való áttérés hatására

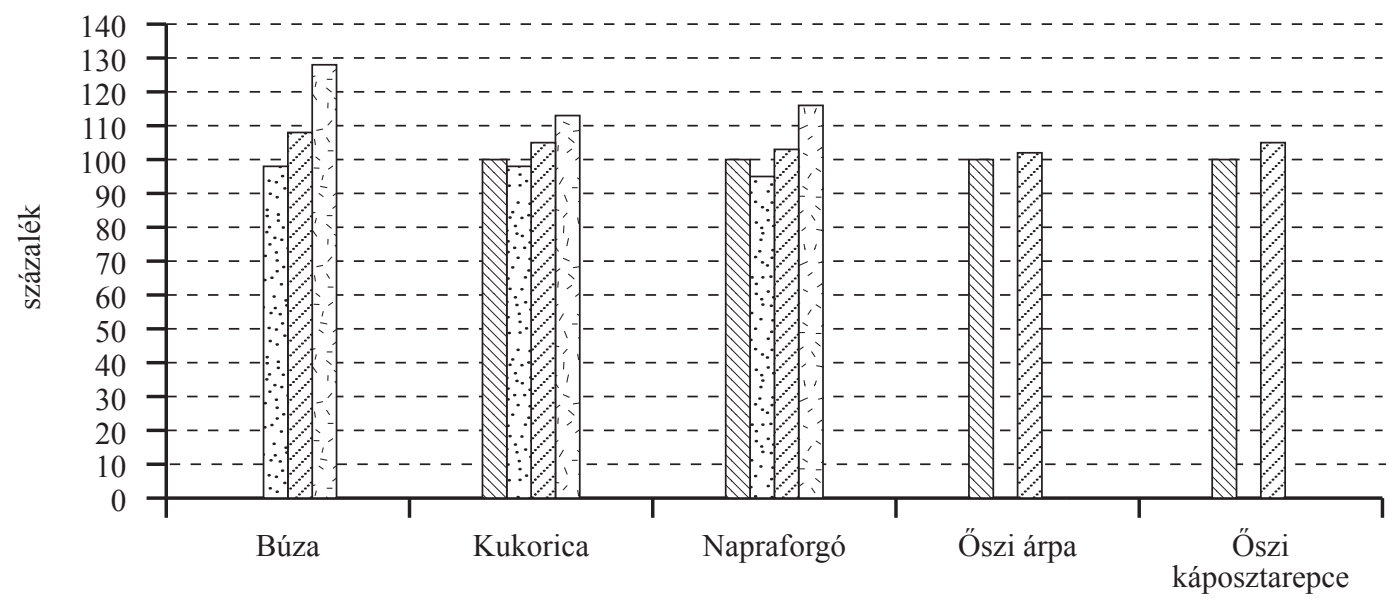

MU Termelési költség precíziós technológia nélkül

Termelési költség a precíziós technológia bevezetésével, minimumszorzó használatával

Termelési költség a precíziós technológia bevezetésével, átlagos szorzó használatával

Termelési költség a precíziós technológia bevezetésével, maximumszorzó használatával

Forrás: Az AKI Horizontális Elemzési Osztályán készült számítások

\section{7. ábra: Az ágazati eredmény változása a precíziós gazdálkodásra való áttérés hatására}

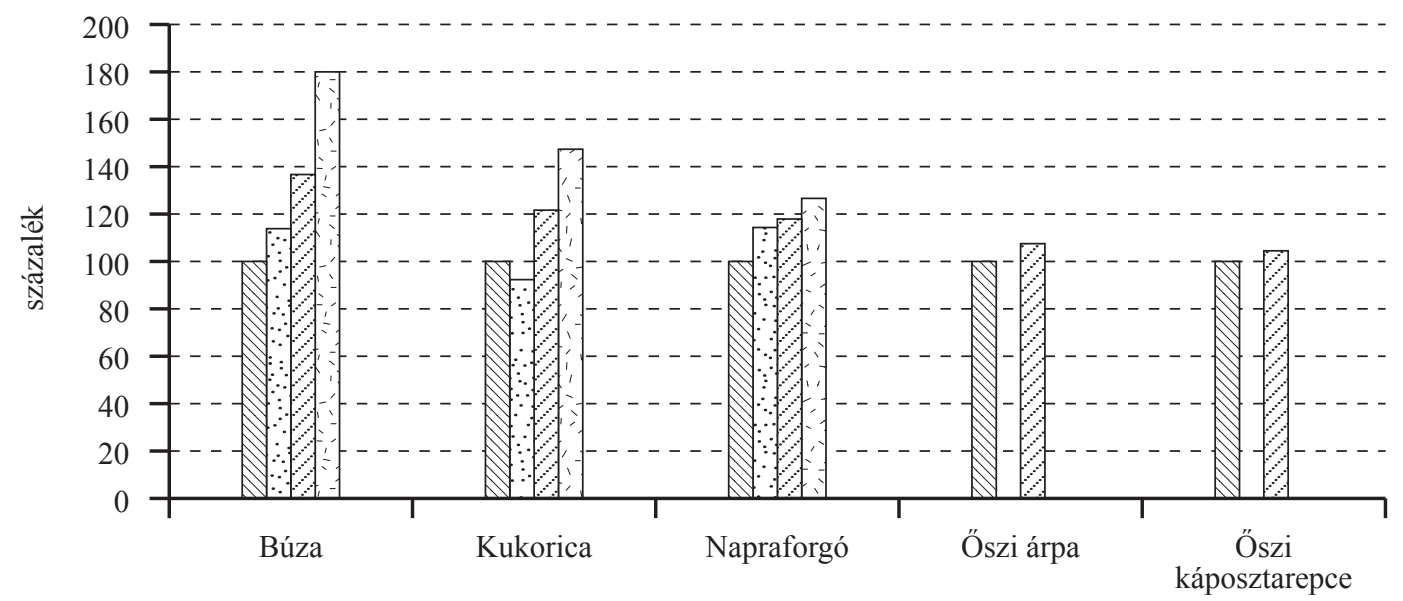

MW Ágazati eredmény precíziós technológia nélkül

Ágazati eredmény a precíziós technológia bevezetésével, minimumszorzó használatával

2 Ágazati eredmény a precíziós technológia bevezetésével, átlagos szorzó használatával

Ágazati eredmény a precíziós technológia bevezetésével, maximumszorzó használatával

Forrás: Az AKI Horizontális Elemzési Osztályán készült számítások

A vetőmagköltség a precíziós gazdálkodás hatására kukoricánál 1-20 százalékkal, azaz minimálisan 0,3 milliárd, maximálisan 6,3 milliárd forinttal növekedne makroszinten. Napraforgónál 0-14 százalékkal (+1,8 milliárd forint), őszi árpánál 3 százalékkal ( 0,1 milliárd forint) haladná meg a vetőmagköltség a korábbi értéket, amennyiben az üzemek áttérnének a precíziós technológiára. 
Búzánál a vetőmagköltség akár 15 százalékkal (2,7 milliárd forinttal) csökkenhet országosan. Ennek hátterében az áll, hogy búzánál a nagyobb hozamú búzafajták vetőmagját használják, ebben az esetben még a magasabb ár mellett is kisebb mennyiséget vetnek el. Ugyanakkor az is elöfordulhat, hogy 5,0 milliárd forinttal (+28 százalék) növekszik a vetőmag költsége. Az öszi árpánál a precíziós gazdálkodásra való átállás hatására makroszinten 0,1 milliárd forinttal, azaz 3 százalékkal emelkedhetnek a vetőmagköltségek. Öszi káposztarepcénél mérsékelten, 282 millió forinttal (-1 százalék) csökkenhet a vetőmag költsége országos szinten (38. ábra).

\section{8. ábra: A vetőmagköltség változása a precíziós gazdálkodásra való áttérés hatására}

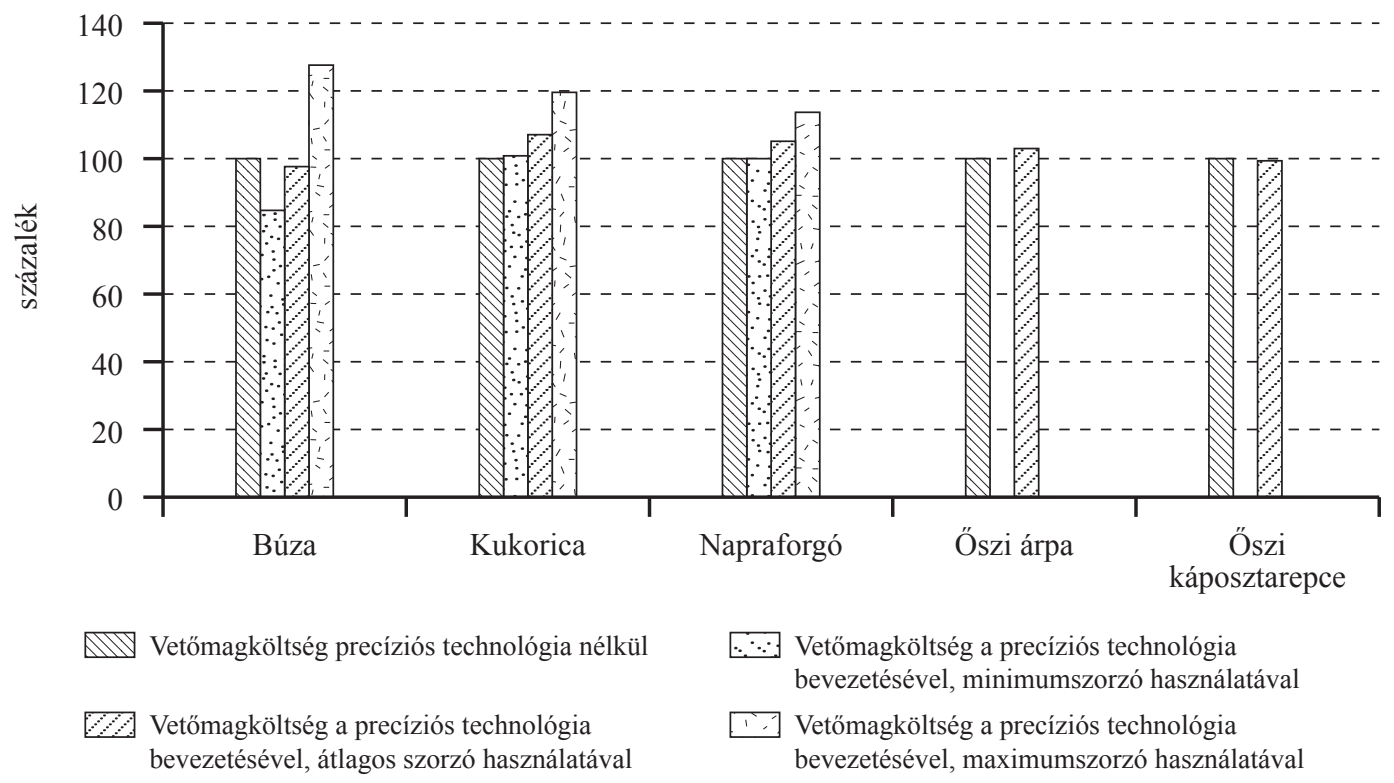

Forrás: Az AKI Horizontális Elemzési Osztályán készült számítások

Intenzív technológia mellett búzánál és kukoricánál akár 4-9 százalékos megtakarítást is eredményezhet a helyspecifikus gazdálkodás a növényvédőszer-költségben országosan, ami forintban kifejezve 0,8-1,9 milliárd forintot jelent. Extenzív technológiáról való áttérés esetén a növényvédöszer-költségek a két növény esetében 23-30 százalékos ( $+5,2-6,4$ milliárd forintnyi) többletköltséget is jelenthetnek makroszinten. Napraforgónál 26 százalékkal (+4,9 milliárd forint), őszi árpánál 2 százalékkal ( $+0,1$ milliárd forint) és őszi káposztarepcénél 9 százalékkal ( $+1,0$ milliárd forint) emelkedhetnek a növényvédő szerre fordított összegek (39. ábra).

A mütrágyaköltség a precíziós gazdálkodás hatására búzánál országosan 15-27 százalékkal, azaz minimálisan 6,3 milliárd forinttal, maximálisan 11,2 milliárd forinttal emelkedhet. Öszi árpánál és őszi káposztarepcénél 0-6 százalékos ( $+0,1-0,4$ milliárd forint) növekedést jelenthet a technológiai váltás. Kukoricánál és napraforgónál makroszinten 5-6 százalékos (-0,9-2,1 milliárd forint) csökkenés is bekövetkezhet, ugyanakkor 21-34 százalékos (+6,0-7,5 milliárd forint) mütrágyaköltségemelkedés is elképzelhető (40. ábra). 
39. ábra: A növényvédőszer-költség változása a precíziós gazdálkodásra való áttérés hatására

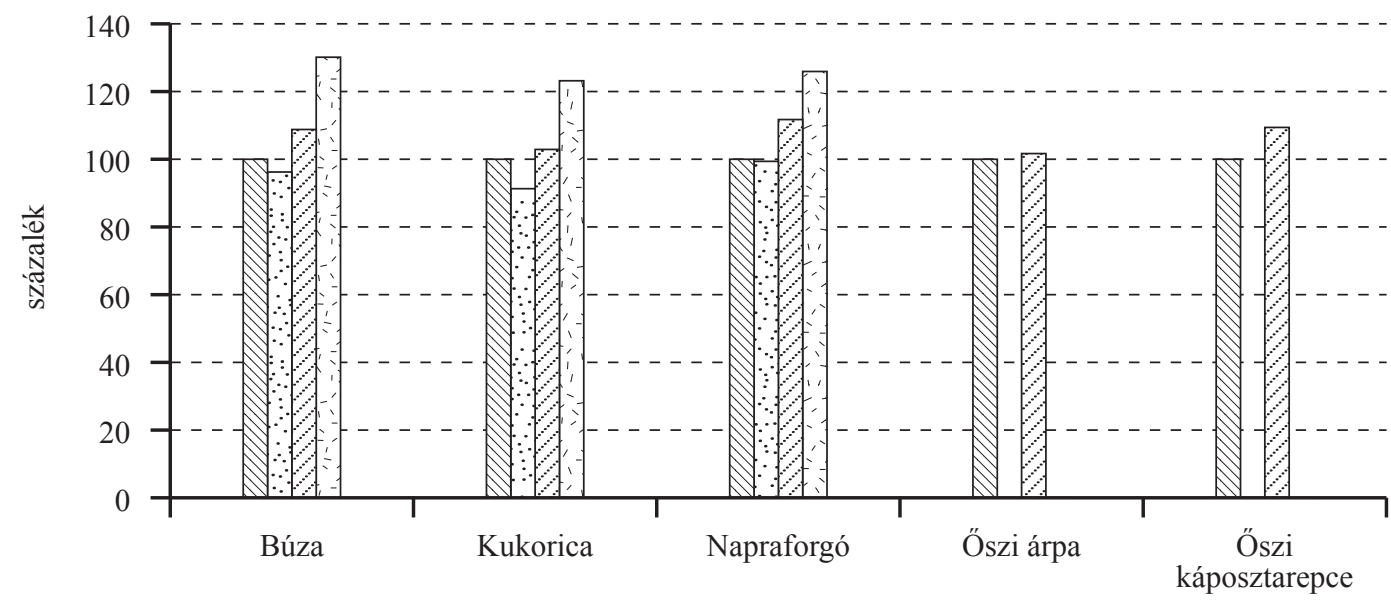

WV̈vényvédőszer-költség precíziós technológia nélkül

Növényvédőszer-költség a precíziós technológia bevezetésével, átlagos szorzó használatával $\therefore$ Növényvédőszer-költség a precíziós technológia bevezetésével, minimumszorzó használatával

19 Növényvédőszer-költség a precíziós technológia bevezetésével, maximumszorzó használatával

Forrás: Az AKI Horizontális Elemzési Osztályán készült számítások

40. ábra: A mütrágyaköltség változása a precíziós gazdálkodásra való áttérés hatására

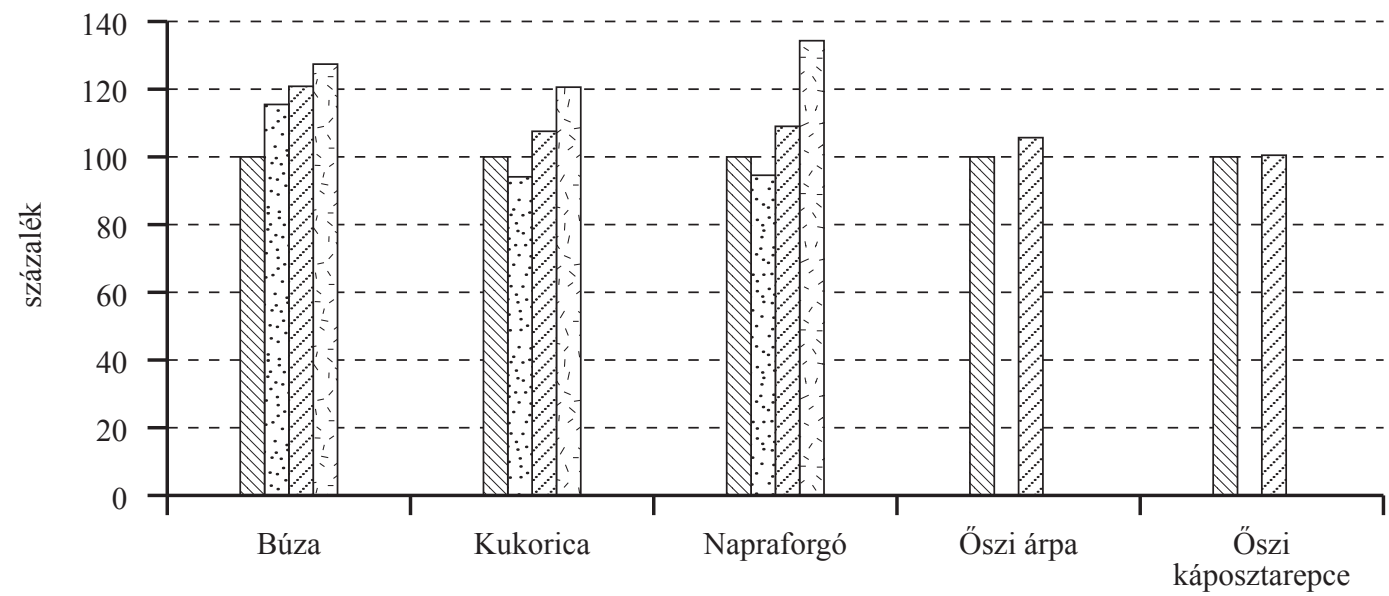

Mütrágyaköltség precíziós technológia nélkül

Mütrágyaköltség a precíziós technológia bevezetésével, minimumszorzó használatával

Mütrágyaköltség a precíziós technológia bevezetésével, átlagos szorzó használatával

I.7 Mütrágyaköltség a precíziós technológia bevezetésével, maximumszorzó használatával

Forrás: Az AKI Horizontális Elemzési Osztályán készült számítások

A precíziós technológiára való áttérés a vizsgált növénykultúrák termésmennyiségében jelentős, legalább 342,6, legfeljebb 858,9 ezer tonna többletet eredményezne. A termelési érték a hozamokhoz hasonlóan növekedne, összességében mintegy 32-140 milliárd forinttal. A termelési költség több mint 10 milliárd forinttal csökkenhet, de akár 100,7 milliárd forinttal is emelkedhet annak megfelelően, hogy intenzíven vagy extenzíven gazdálkodó üzemek térnek át a precíziós technológiák 
alkalmazására. Az inputanyagköltségek szintén változatosan alakulnak, amely alól a mütrágya képez kivételt, ahol minden esetben növekedést lehet kimutatni. A vizsgált ágazatok eredménye viszont összességében számottevően, legalább 15,2, legfeljebb 88,2 milliárd forinttal meghaladná a hagyományos technológiával elérhető jövedelmet (21. táblázat).

\section{1. táblázat: A technológiaváltás becsült hatása a termelési tényezőkre}

\begin{tabular}{lcc}
\hline \multicolumn{1}{c}{ Termelési tényezők } & \multicolumn{2}{c}{ Változás összesen } \\
\cline { 2 - 3 } & Minimum & Maximum \\
\hline Termésmennyiség, ezer tonna & 342,6 & 858,9 \\
\hline Termelési érték, milliárd HUF & 32,1 & 139,6 \\
\hline Termelési költség, milliárd HUF & $-10,4$ & 100,7 \\
\hline Ágazati eredmény, milliárd HUF & 15,2 & 88,2 \\
\hline Vetömagköltség, milliárd HUF & $-2,3$ & 13,2 \\
\hline Mütrágyaköltség, milliárd HUF & 3,8 & 25,2 \\
\hline Növényvédőszer-költség, milliárd HUF & $-1,7$ & 17,6 \\
\hline
\end{tabular}

Forrás: Az AKI Horizontális Elemzési Osztályon készült számítások

\subsection{A precíziós gazdálkodás beruházási költségei}

Az eddigiekben már bemutattuk, hogy milyen hatással járna a precíziós technológia bevezetése a termelés mennyiségére, értékére, illetve a költségekre és az eredményre. Jelen fejezetben azt vizsgáljuk, hogy a vázolt hatások eléréséhez milyen beruházások szükségesek üzemi és makroszinten, azok mekkora beruházási költséggel járnak, és hogy a technológia bevezetésének forrásigénye hogyan viszonyul a realizálható előnyökhöz.

Amennyiben azon üzemek, amelyekre vonatkozóan igazolni tudtuk a technológia előnyeit, végrehajtanák a technológiaváltást az öt növény termelésében, akkor összesen 21473 üzem foglalkozna precíziós gazdálkodással együttesen 1,36 millió hektáron.

A precíziós technológiára való áttérés beruházási költségét illetően nem mindegy, hogy

- a beruházásnál teljes gépparkcserét kell-e végrehajtani,

- a meglévő gépparkot szükséges precíziós eszközökkel felszerelni, vagy

- csak szerkezeti elemeket, illetve szoftvereket kell beszereznie az üzemnek.

A teljes gépparkcsere a gyakorlatban ritkán fordul elő, inkább a folyamatos átállás a jellemző. E három szcenárió költségére vonatkozóan a KITE Zrt. által rendelkezésre bocsátott adatok alapján végeztünk becslést.

Annak megítéléséhez, hogy az egyes üzemeknél a háromféle szcenárió közül melyiket vegyük figyelembe a számításnál, a precíziós gazdálkodásra áttérö üzemeket eszközállományuk elhasználódottsága alapján három csoportra bontottuk. Az első csoportba azon üzemek kerültek, ahol a bruttó és a nettó eszközállomány értékének különbsége több mint 70 százalék, tehát a gépek, eszközök értékének több mint 70 százaléka leírásra került. Ezen üzemek esetében feltételeztük, hogy a géppark avultsága miatt nem alkalmas a precíziós gazdálkodásra, és a teljes eszközállomány cseréje szükséges a technológia bevezetéséhez. A második csoportba a 40 és 70 százalék közötti elhasználódottságú eszközállománnyal rendelkező gazdák kerültek. Itt feltételeztük, hogy az eszközök felszerelhetők olyan kiegészítőkkel, amelyek alkalmassá teszik azokat a precíziós gazdálkodásra. A harmadik csoportba a 40 százaléknál alacsonyabb elhasználódottságú gépparkkal rendelkező üzemek kerültek. Itt feltételeztük, hogy a géppark alkalmas a precíziós gazdálkodásra és már csak 
a precíziós gazdálkodáshoz szükséges szoftverek, GPS-jelkorrekció és szaktanácsadás szükséges a helyspecifikus gazdálkodás elindításához (20-26. melléklet). A fenti csoportosításon túl az üzemeket méretük alapján 1000 hektár alatti és 1000 hektár feletti területeken gazdálkodókra osztottuk.

Első esetben azon üzemeknél vizsgáltuk a beruházási költségeket, amelyek ha áttérnének a precíziós gazdálkodásra, akkor komplett gépparkcserét hajtanának végre. A 21473 üzemből 8955 azon gazdaságok száma, amelyek 1000 hektár alatt gazdálkodnának precíziósan a jövőben, az 1000 hektár feletti üzemek száma ennél lényegesen kevesebb, 790 lenne. A vetésterület az 1000 hektár alatti üzemeknél összágazati szinten 370 ezer hektár körül, az 1000 hektár felettieknél 300 ezer hektár körül alakulna (22. táblázat).

A beruházási költségek makroszinten az 1000 hektár alatt gazdálkodóknál több mint kétszeresét tennék ki az 1000 ha felettiekének a teljes géppark cseréje esetében, míg az ágazati eredmények precíziós gazdálkodásból fakadó többlete egyaránt 10 milliárd forint felett alakulna a kis- és nagyüzemeknél. Üzemszinten átlagosan a kisüzemek 40 hektáron, a nagyüzemek 380-430 hektáron végeznének precíziós termelést, a beruházási költségek a kisebb gazdaságokban egy hektárra vetítve 500 ezer forint felett alakulnának, a nagyüzemeknél ugyanezen érték alacsonyabb, 328 ezer forint lenne. A beruházási költségek üzemszinten az 1000 hektárnál kisebb gazdaságok esetében 22 millió forint felett, az 1000 hektár felettieknél 125-139 millió forint között változnának számításaink szerint.

\section{2. táblázat: Becslések a géppark teljes (komplett) cseréjét igénylő üzemekre vonatkozóan}

\begin{tabular}{|c|c|c|c|}
\hline & Megnevezés & 1000 ha alatti üzemek & 1000 ha feletti üzemek \\
\hline \multirow{4}{*}{ 竞 } & Precíziós üzemek száma a jövőben, db & 8955 & 790 \\
\hline & Precíziós vetésterület a jövőben, ha & 366958 & 301647 \\
\hline & Beruházási költség, millió HUF & 199148 & 98955 \\
\hline & Ágazati eredménytöbblet, millió HUF & 11204 & 10502 \\
\hline \multirow{5}{*}{ 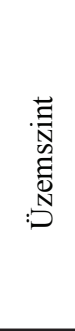 } & $\begin{array}{l}\text { Precíziós terület átlagos nagysága üzemenként, } \\
\text { ha/üzem }\end{array}$ & 41 & 382 \\
\hline & Beruházási költség, HUF/ha & 542700 & 328050 \\
\hline & Beruházási költség, HUF/üzem & 22238118 & 125221125 \\
\hline & $\begin{array}{l}\text { Jövedelemtermelö képesség becsült növekedése, } \\
\text { HUF/ha }\end{array}$ & 30532 & 34815 \\
\hline & $\begin{array}{l}\text { Nettó jelenérték } 7 \text { éves megtérülés és } \\
3 \text { százalékos kamat esetén, HUF/ha }\end{array}$ & -352477 & -111143 \\
\hline
\end{tabular}

Forrás: A KITE Zrt. adatai és az FADN-adatbázis alapján készült az AKI Horizontális Elemzési Osztályán

A precíziós gazdálkodás többletjövedelmét az egyes ágazatok többletjövedelméből számoltuk ki, amelynek során úgy kalkuláltunk, hogy búza esetében 61, kukoricánál 48, napraforgónál 35, őszi káposztarepcénél 40 és őszi árpánál 30 százalékkal nő a jövedelem. Ezeket az arányokat úgy alkalmaztuk a jövedelemtermelő képesség becsült növekedésének meghatározásakor, hogy a technológiaváltást végrehajtó üzemek növénykultúránkénti vetésterületének méretét is figyelembe vettük.

Üzemszinten a beruházási költség és az átlagos jövedelemnövekedés egy hektárra vetített értékei alapján vizsgáltuk a beruházás megtérülését. A nettó jelenérték alapján a teljes gépparkcsere - 3 százalékos kamat és 7 éves megtérülési idő esetén - sem a kisüzemek, sem a nagyüzemek esetében nem térülne meg (22. táblázat).

Megjegyzendő azonban, hogy a magas beruházási költségek nemcsak a precíziós technológiára való áttérés költségét jelentik a komplett csere esetében, hanem az elavult gépek cseréjét is magukban foglalják, amely abban az esetben is jelentkezne, ha az üzem nem térne át a precíziós gaz- 
dálkodásra. Éppen ezért azt is megvizsgáltuk, hogy hogyan alakulna az előbbi üzemek esetében a megtérülés, ha a gazdálkodók csak a géppark precíziós eszközökkel való felszerelését végeznék el (23. táblázat).

\section{3. táblázat: Becslés a géppark teljes (komplett) cseréjét igénylő üzemekre vonatkozóan, amennyiben a gazdaságoknak ,csak” a precíziós eszközökkel való felszerelésére kerül sor}

\begin{tabular}{|c|c|c|c|}
\hline & Megnevezés & 1000 ha alatti üzemek & 1000 ha feletti üzemek \\
\hline \multirow{4}{*}{ 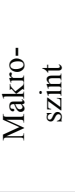 } & Precíziós üzemek száma a jövőben, db & 8955 & 790 \\
\hline & Precíziós vetésterület a jövőben, ha & 366958 & 301647 \\
\hline & Beruházási költség, millió HUF & 22091 & 8235 \\
\hline & Ágazati eredménytöbblet, millió HUF & 11204 & 10502 \\
\hline \multirow{5}{*}{ 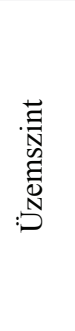 } & $\begin{array}{l}\text { Precíziós terület átlagos nagysága üzemenként, } \\
\text { ha/üzem }\end{array}$ & 41 & 382 \\
\hline & Beruházási költség, HUF/ha & 60200 & 27300 \\
\hline & Beruházási költség, HUF/üzem & 2466804 & 10420779 \\
\hline & $\begin{array}{l}\text { Jövedelemtermelö képesség becsült növekedése, } \\
\text { HUF/ha }\end{array}$ & 30532 & 34815 \\
\hline & $\begin{array}{l}\text { Nettó jelenérték } 7 \text { éves megtérülés } \\
\text { és } 3 \text { százalékos kamat esetén, HUF/ha }\end{array}$ & 130023 & 189607 \\
\hline
\end{tabular}

Forrás: A KITE Zrt. adatai és az FADN-adatbázis alapján készült az AKI Horizontális Elemzési Osztályán

Az eredmények azt jelzik, hogy ez esetben a nettó jelenérték 130,0 ezer és 189,6 ezer forint hektáronként, vagyis megtérül a beruházás mind az 1000 hektárnál kisebb, mind pedig az 1000 hektárnál nagyobb gazdaságoknál.

A harmadik esetben azokra az üzemekre vonatkozóan végeztünk becslést, amelyeknek az eszközállománya 40-70 százalékos elhasználódással bírt, vagyis nincs szükségük a géppark teljes cseréjére, „,csak” precíziós eszközökkel történő felszerelésére. Ez a kitétel összesen 8323 üzemet érintett azon üzemek közül, amelyekre tudtuk igazolni a technológiaváltás elönyeit, ezek zöme (7853 gazdaság) 1000 hektárnál kisebb területtel bír, 470 pedig 1000 hektár felettivel. A vetésterület előbbieknél mintegy 350 ezer hektár, utóbbiaknál 184 ezer hektár körül alakult. A beruházási költségek makroszinten az 1000 hektár alatt gazdálkodóknál több mint négyszeresét tennék ki a nagyüzemek hasonló értékének, míg az ágazati jövedelem precíziós gazdálkodásból származó többlete 10 milliárd forint felett alakulna a kisüzemeknél és 5 milliárd forint felett az 1000 hektárnál nagyobb üzemeknél.

Üzemszinten a kisüzemek átlagosan 44 hektáron, a nagyüzemek 390 hektáron végeznének precíziós termelést, a beruházási költség a kisebb gazdaságokban nagyságrendileg 60 ezer forint lenne hektáronként, a nagyüzemeknél ennek kevesebb mint fele, 27 ezer forint. A precíziós gazdálkodásra történő áttérés beruházási költsége 1000 hektár alatt gazdálkodók esetében 2,6 millió forint környékén, nagyüzemeknél 10,6 millió forint körül alakulna.

Összevetve a beruházás költségeit és az azoknak tulajdonítható többletjövedelmet elmondható, hogy a meglévő géppark precíziós eszközökkel történő felszerelése mindkét esetben megtérülne. A kisüzemeknél 134,2, a nagyüzemeknél 156,6 ezer forint az egy hektárra vetített nettó jelenérték (24. táblázat).

Végül, de nem utolsósorban azon üzemeknél vizsgáltuk a precíziós gazdálkodásra való átállás megtérülését, amelyeknél az eszközállomány elhasználódottsága 40 százaléknál alacsonyabb volt. A vizsgálatba bevont ilyen gazdaságok száma 3406 volt, amelyek közül 3300 üzem 1000 hektárnál kisebb területen gazdálkodott. A müvelésükbe vont precíziós terület a jövőben a kisebb méretü 
üzemeknél együttesen 125,4 ezer hektár, míg a nagyobbaknál 34,5 ezer hektár lenne. A technológiaváltás beruházási költségei makroszinten az 1000 hektár alatti területen gazdálkodóknál közel hatszorosát tennék ki a nagyüzemekhez képest (25. táblázat).

\section{4. táblázat: Becslések azon üzemekre vonatkozóan, amelyeknél a géppark} precíziós eszközökkel való felszerelése lenne indokolt

\begin{tabular}{|c|c|c|c|}
\hline & Megnevezés & 1000 ha alatti üzemek & 1000 ha feletti üzemek \\
\hline \multirow{4}{*}{ 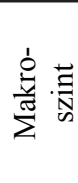 } & Precíziós üzemek száma a jövőben, db & 7853 & 470 \\
\hline & Precíziós vetésterület a jövőben, ha & 348571 & 183383 \\
\hline & Beruházási költség, millió HUF & 20984 & 5006 \\
\hline & Ágazati eredménytöbblet, millió HUF & 10877 & 5412 \\
\hline \multirow{5}{*}{ 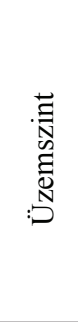 } & $\begin{array}{l}\text { Precíziós terület átlagos nagysága üzemenként, } \\
\text { ha/üzem }\end{array}$ & 44 & 390 \\
\hline & Beruházási költség, HUF/ha & 60200 & 27300 \\
\hline & Beruházási költség, HUF/üzem & 2672260 & 10655675 \\
\hline & $\begin{array}{l}\text { Jövedelemtermelö képesség becsült növekedése, } \\
\text { HUF/ha }\end{array}$ & 31204 & 29510 \\
\hline & $\begin{array}{l}\text { Nettó jelenérték } 7 \text { éves megtérülés } \\
\text { és } 3 \text { százalékos kamat esetén, HUF/ha }\end{array}$ & 134210 & 156556 \\
\hline
\end{tabular}

Forrás: A KITE Zrt. adatai és az FADN-adatbázis alapján készült az AKI Horizontális Elemzési Osztályán

\section{5. táblázat: Becslések azon üzemekre vonatkozóan, amelyeknél a géppark szoftverekkel, illetve szerkezeti elemekkel való felszerelése lenne indokolt}

\begin{tabular}{|c|c|c|c|}
\hline & Megnevezés & 1000 ha alatti üzemek & 1000 ha feletti üzemek \\
\hline \multirow{4}{*}{ 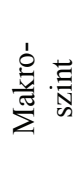 } & Precíziós üzemek száma a jövőben, db & 3300 & 106 \\
\hline & Precíziós vetésterület a jövőben, ha & 125397 & 34453 \\
\hline & Beruházási költség, millió HUF & 752 & 123 \\
\hline & Ágazati eredménytöbblet, millió HUF & 4474 & 1780 \\
\hline \multirow{5}{*}{ 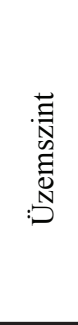 } & $\begin{array}{l}\text { Precíziós terület átlagos nagysága üzemenként, } \\
\text { ha/üzem }\end{array}$ & 38 & 326 \\
\hline & Beruházási költség, HUF/ha & 6000 & 3563 \\
\hline & Beruházási költség, HUF/üzem & 227994 & 1162724 \\
\hline & $\begin{array}{l}\text { Jövedelemtermelö képesség becsült növekedése, } \\
\text { HUF/ha }\end{array}$ & 35678 & 51653 \\
\hline & $\begin{array}{l}\text { Nettó jelenérték } 7 \text { éves megtérülés } \\
\text { és } 3 \text { százalékos kamat esetén, HUF/ha }\end{array}$ & 216284 & 201791 \\
\hline
\end{tabular}

Forrás: A KITE Zrt. adatai és az FADN-adatbázis alapján készült az AKI Horizontális Elemzési Osztályán

Az ágazati eredmények tekintetében a precíziós gazdálkodás révén mintegy 4,5 milliárd forint többlet keletkezne a kisüzemeknél és 1,8 milliárd forint az 1000 hektár feletti gazdaságoknál. A kisüzemek átlagosan 38 hektáron, a nagyüzemek 326 hektáron végeznének precíziós termelést, a beruházási költség a kisebb gazdaságokban hektáronként 6 ezer forintra becsülhető, a nagyüzemeknél 3,6 ezer forintra. A precíziós gazdálkodásra történő áttérés után a beruházási költség az 1000 hektár alatti gazdálkodók esetében 227 ezer forint körül, a nagyüzemeknél 1,2 millió forint körül alakulna.

A beruházás költségét és a többletjövedelmeket szembeállítva megállapítható, hogy üzemszinten a beruházás szoftverbeszerzése mindkét méretkategóriánál megtérülne. Számításaink szerint a kisüzemek hektáronként 216,3 ezer forintot, a nagyüzemek 201,8 ezer forint nettó eredményt realizálhatnának a precíziós technológiára való áttérés eredményeként (25. táblázat). 
Összességében megállapítható, hogy a gazdálkodóknak - az 1000 ha alatti és feletti területtel rendelkezőknek egyaránt - mind a szerkezeti elemekkel és szoftverekkel történő felszerelés, mind pedig a precíziós eszközökkel való felszerelés megéri, mert annak költsége bőven megtérül a technológia eredményeként keletkező többletjövedelmekben. A teljes gépparkcserénél a megtérülés nem igazolódott. Ennek kapcsán azonban meg kell jegyezni, hogy mivel a gépek az üzem teljes területén használatosak, illetve nem csak a többleteredmények elérésében játszanak szerepet, így nem is várható a beruházási költségüknek a precíziós többletjövedelmekben való megtérülése. 


\section{A precíziós gazdálkodás elterjedését befolyásoló tényezők és a korlátok megszüntetésére tett javaslatok}

\subsection{Az elterjedést korlátozó, illetve segítő tényezők}

Az élelmiszer-biztonság és a fenntarthatóság iránti növekvő igény, valamint a környezetvédelmi szempontok a mezőgazdasági források hatékony felhasználására hívják fel a figyelmet (Tey és Brindal, 2012). Ennek egyik eszköze lehet a precíziós gazdálkodás, ami Magyarországon is több mint másfél évtizedes múltra tekint vissza, sokak előtt azonban még ma is ismeretlen. Lassú terjedésének okai közt legtöbbször a magas beruházási költségeket, a rendszer bonyolultságát és az ismeretek hiányát említik, de számos egyéb tényező is befolyásolja azt. A technológia bevezetéséből származó elméleti előnyök gyakorlati megvalósulása nagymértékben függ a terület heterogenitásától és a gazdálkodó képességeitől is (Lencsés et al., 2014).

\subsubsection{Agroökológiai tényezők és gazdaságméret}

Egy gazdaságnak akkor érdemes bevezetnie a precíziós, helyspecifikus gazdálkodást, ha a müvelt területeire nagyfokú heterogenitás jellemző, ugyanis minél heterogénebb a tábla, annál nagyobb mértékủ változások érhetők el a hagyományos növénytermelési technológiához viszonyítva. Egy adott terület heterogenitása a különböző agrotechnológiai elemek szempontjából sem egyforma, ezért nem adható meg egyértelmüen, hogy mekkora terület (pl. 100, 250 vagy 1000 ha) felett éri meg a precíziós gazdálkodásra való átállás. Magyarországon a polarizált és fragmentált gazdaságszerkezet a precíziós mezőgazdaságot gátló tényezők közé sorolható (Lencsés et al., 2014). Kisméretü egyéni vagy családi gazdaságokban a precíziós növénytermelés közös géphasználattal vagy szolgáltatások igénybevételével valósítható meg gazdaságosan (Kuttler, 2011; Takácsné György, 2015).

A klímaváltozás több szempontból is ösztönzőleg hathat a precíziós gazdálkodás terjedésére. Az egyre gyakoribb szélsőséges időjárási viszonyok miatt legtöbbször rövid idő áll rendelkezésre egy-egy munkafolyamat elvégzésére, ilyenkor a GPS-es jármü-navigáció, valamint a nem teljes táblán végzett műveletek jelentős segítséget nyújtanak. A klímaváltozás felerősítheti az évek közötti eltéréseket, valamint a táblán belüli heterogenitásokat is. A kiegyenlített hozamok eléréséhez a helyspecifikus, valamint a talajkímélő gazdálkodás nagymértékben hozzájárulhat.

\subsubsection{Technikai tényezők}

A szükséges gépek, szenzorok és vezérlők ma már széles körben elérhetők, sőt, Takácsné György (2015) szerint a technológiai nyomás a gyártó-forgalmazó szervezetek részéröl erős. A precíziós gazdálkodás beruházási igénye nagy, de nem szükséges minden elemet egyszerre bevezetni, lehetőség van a hagyományos gazdálkodás, valamint a teljesen precíziós megoldásokra alapozott rendszer közötti fokozatos átállásra.

Évente több szakmai bemutató kerül megszervezésre, melyeken lehetőség van az új technológia, illetve az új gépek és eszközök megismerésére. A KITE Zrt. technológiai gépbérletnek nevezett programjával olyan gazdálkodók is kipróbálhatják a precíziós gazdálkodás lehetőségeit - alapmüvelés, vetés, növényápolás, betakarítás -, akik nem akarnak rögtön egy komolyabb beruházásba belevágni.

A helyspecifikus gazdálkodás fontos eleme a pontos helymeghatározás. A GPS-eszközök ára az utóbbi években folyamatosan csökken, és a tendencia folytatása várható, így ez már nem tekinthető korlátozó tényezőnek.

Az Informatikai, Távközlési és Elektronikai Vállalkozások Szövetsége (IVSZ, 2016b) szerint problémát jelent, hogy a precíziós technológiákat és eszközöket a magyar gazdálkodók nagyrészt 
azokon az integrátorokon keresztül érik el, akik az RTK-jeleket szolgáltatják. Mivel az integrátorok erősen kötődnek egy-egy nagy gépgyártóhoz, ez hosszú távú elköteleződést jelent a gépgyártók felé is.

Több tanulmány kiemeli, hogy a szabványok hiánya, az eszközök gyors változása, a köztük lévő inkompatibilitás és néhány esetben a nem eléggé felhasználóbarát eszközök mind gátolják a technológia terjedését, illetve növelik a kockázatot (Aubert et al., 2012; EIP-AGRI, 2015; BIS Research, 2016; Erickson és Widmar, 2015; IVSZ, 2016b). A kompatibilitási problémák megoldására jelentős lépés volt az ISOBUS-protokoll bevezetése, ami standardizált kommunikációt tesz lehetővé a munkagép, a mezőgazdasági eszközök, valamint a vezérlést ellátó terminál között. Ezáltal egyetlen terminállal megoldható bármely gyártó ISOBUS-t támogató eszközének vezérlése.

Az erőgépek CAN-bus rendszeréről gyüjtött gépüzemeltetési adatok - például motor müködése, sebesség, üzemanyag-fogyasztás - hasznos információt szolgáltatnak nemcsak a szervizeléshez, hanem a munkafegyelem ellenőrzéséhez is. Ez ma még egy kevesbé kihasznált lehetőség, pedig hozzájárulhat a hatékonyság növeléséhez.

A sokféle adatformátum megnehezíti a különböző szenzorokból származó adatok feldolgozását és együttes értékelését, valamint a gazdálkodók, szaktanácsadók és kutatók közti adatmegosztást is (EIP-AGRI, 2015). Új kihívást jelent a nagy mennyiségü adat (,,Big Data”) feldolgozása is. Tamás (2016) szerint 1000 hektár precíziós mezőgazdasági területen egy év alatt 25 millió mérési adat keletkezik - Sulyok (2016) szerint ez az adatszám jóval nagyobb is lehet -, amiket integrálni kell, és speciális adatbányászati technológiák szükségesek a feldolgozásukhoz.

Ugyanakkor egyre több olyan szoftver jelenik meg a piacon, amely a munkafolyamatok során gyüjtött adatokból képes előállítani a jogszabályok által előírt táblatörzskönyvet, gazdálkodási vagy permetezési naplót, ezzel jelentősen segítve a gazdálkodót.

Összességében az eddigi erőfeszítések (pl. ISOBUS) ellenére az jelenti a legnagyobb technikai problémát, hogy az általános iparági sztenderdek hiánya miatt az egyes gépgyártók eszközei és az azokat müködtető szoftverek között gyakran nincs vagy alig létezik kombatibilitás, illetve nem elsődleges gyártói szempont ezen kompatibilitásra való törekvés. Ennek oka az, hogy így egy-egy nagy, teljes gépportfóliót gyártó vállalat idővel kikényszerítheti a teljes gépsora (a vezértraktortól az ekéig) megvételét, mivel csak ezen a gépsoron válik müködőképessé a precíziós technológia.

\subsubsection{Gazdasági tényezők}

A gazdálkodók profitorientáltak, így elsősorban olyan újdonságokat vezetnek be, amelyek egyértelmüen jövedelemtöbbletet eredményeznek. A nemzetközi szakirodalom és a hazai felmérés alapján is az egyik legfontosabb gátló tényező a magas beruházási költség, valamint az, hogy a technológia bevezetéséből származó költségcsökkenés, illetve magasabb jövedelmezőség nem kellően alátámasztott.

A gépek beruházási költségei a 22-25. táblázatban bemutatásra kerültek, a fontosabb eszközökre vonatkozóan a 26. táblázat ad áttekintést. Az árak egy eszköztípuson belül is széles tartományban mozognak az eszköz képességeitől függően. A forgalmazók gyakran nem külön eszközöket, hanem csomagokat ajánlanak a gazdálkodóknak, melyek az eszközök mellett tartalmazhatnak RTKelöfizetést, szoftvert vagy oktatást is. 
26. táblázat: A fontosabb precíziós eszközök várható költsége

\begin{tabular}{|c|c|}
\hline Eszköz & Nettó ár, ezer HUF \\
\hline GPS-antenna & $290-2500$ \\
\hline RTK-bázisállomás & $2400-3400$ \\
\hline GPS-es területmérő & $170-350$ \\
\hline Sorvezető (antenna + monitor) & $280-4000$ \\
\hline Kormányautomatika & $630-3800$ \\
\hline Robotpilóta & $2600-4400$ \\
\hline Kijuttatásvezérlő & $630-750$ \\
\hline Növényszenzor (kézi - 4 szenzoros, fronthidraulikára szerelhető) & $86-6300$ \\
\hline Hozamtérképező rendszer & $950-1200$ \\
\hline
\end{tabular}

Forrás: Forgalmazók katalógusai

\subsubsection{Társadalmi tényezők}

A korábban említett problémák ellenére sok üzemben nem a technikai háttér biztosítása, hanem az információk interpretálási nehézsége, valamint a szemléletváltás akadályozzák a precíziós gazdálkodásra való áttérést.

Az új technológiák bevezetésére általában a magasabb iskolai végzettségü fiatal gazdálkodók vállalkoznak (Kalmár, 2010; Antolini et al., 2015), de néhány tanulmány szerint a kor nem jelentős vagy éppen pozitív korrelációt mutató tényező a precíziós gazdálkodás bevezetése során (Aubert et al., 2012; Tey és Brindal, 2012). Magyarországon a gazdaságvezetők és a foglalkoztatottak esetében is jellemző az elöregedés és a szakképzettség hiánya. A 2013-as gazdaságszerkezeti összeírás alapján (KSH, 2015) a gazdálkodók 60 százaléka 55 év feletti és 31 százaléka 65 év feletti volt. Felsőfokú végzettséggel kevesebb mint 3 százalék rendelkezett, a döntő többség (közel 80 százalék) csak a gyakorlati tapasztalatára támaszkodott. A 2016. évi összeírás alapján a gazdálkodók 31 százaléka továbbra is 65 év feletti, míg a 35 év alattiak aránya 6 százalék. A gazdálkodók mezőgazdasági végzettség szerinti összetétele az elmúlt években kicsit kedvezőbbé vált, a felsőfokú végzettséggel rendelkezők aránya 3,4 százalékra, a középfokú végzettséggel rendelkezőké 10 százalékra emelkedett, de a gazdálkodók háromnegyede továbbra is kizárólag a gyakorlati tapasztalatára támaszkodik (KSH, 2016).

A rendszer összetettsége miatt (lásd 1. fejezet) a technológia bevezetéséhez mindenképpen szükség van a gazdálkodó, valamint a gazdálkodásban részt vevő minden munkavégző szaktudására, elkötelezettségére, nyitottságára és a szaktanácsadók iránymutatására (Lencsés et al., 2014; ZarcoTejada et al., 2014). Erickson és Widmar (2015) szerint a technológia terjedéséhez fontosabb a jó mezőgazdasági tudás, mint a technikai ismeretek. Az IVSZ (2016b) szerint a hazai mezőgazdaságban az informatikai megoldások terjedésének legfőbb korlátja a humán erőforrás felkészületlensége, nem megfelelő készségei és attitűdje. Megfelelő szaktudás és az elkötelezettség hiányában a termelők nem képesek a precíziós eszközök adta gazdasági lehetőségek kihasználására (Lencsés et al., 2014; Takácsné György, 2015). Az elmúlt években azonban számos jó példát láthatunk Magyarországon is (Sinka és Mesterházi, 2014; Sulyok, 2016). Az Év Agrárembere Díj növénytermesztés kategóriájának győztese 2014-ben a hazai precíziós gazdálkodás egyik ,úttörője”, Farkas László lett, és a díj 2016. évi jelöltjei közül is többen kapcsolódtak a precíziós gazdálkodáshoz.

A precíziós gazdálkodás kapcsán - elsősorban a kis gazdaságok esetén - együttmüködésre lehet szükség a gépek közös beszerzése, a bevezetéshez szükséges szolgáltatások igénybevétele, valamint az adatok feldolgozása és értelmezése kapcsán (Kutter et al., 2011). Lencsés et al. (2014) szerint Magyarországon jelentős gátló tényező a vállalkozókedv hiánya, valamint a gazdák együttmükö- 
désre való hajlandóságának alacsony szintje. Ugyanakkor Takács és Baranyai (2010) tanulmánya szerint a fiatalabbak közt nagyobb az együttmüködés elfogadottsága, ami az agráriumban várható generációváltás bekövetkeztével esélyt ad az együttmüködési formák megerősödésére.

A világ nagy mezőgazdasági és élelmiszeripari vállalatait tömörítő Global Harvest Initiative szerint a gazdálkodók többsége szeretné igénybe venni egy program vagy szaktanácsadó segítségét az adatelemzésben (Zeigler és Steensland, 2015), ugyanakkor vonakodnak megosztani az adataikat másokkal. Sokan félnek attól - az American Farm Bureau (2014) felmérése szerint 77,5 százalék -, hogy a nagy mennyiségü adatuk a tudtuk és engedélyük nélkül eljuthat a hatóságokhoz vagy a saját érdekeik ellen használják fel azokat (EIP-AGRI, 2015).

\subsubsection{Oktatás, szaktanácsadás}

A precíziós gazdálkodás alkalmazásához egyaránt szükségesek az agrotechnológiai, a műszaki, az informatikai és a menedzsmentismeretek.

A középfokú mezőgazdasági képzések tematikájában nincs nevesítve a precíziós gazdálkodás, de két szakképző iskola (Galamb József Mezőgazdasági Szakképző Iskola Makón és Csukás Zoltán Mezőgazdasági Szakképző Iskola Csornán) honlapjáról kiderül, hogy ezzel is megismertetik a diákokat. Jelentős előrelépést jelent, hogy a Mezőgazdasági Gépforgalmazók Országos Szövetsége (MEGFOSZ) és az FM Agrárszakképzésért felelős helyettes államtitkárságának 2014-ben elindult együttműködése nyomán az FM fenntartásában működő mezőgazdasági szakiskolákban lehetővé vált a duális képzés, ahol a mezögépész tanulók a termelésben, a gazdálkodóktól sajátíthatják el a modern gépek használatát, müködtetését - egyes esetekben a precíziós gazdálkodás elemeit.

A hazai agrár-felsőoktatási intézményekben már mindenhol szerepel a tananyagban a precíziós gazdálkodás témakör, de ez legtöbbször csak pár órát jelent egy-egy tárgy keretében. Önálló tárgyként a Debreceni Egyetemen, a Nyíregyházi Egyetemen, a Miskolci Egyetemen, a Pannon Egyetemen, valamint a Széchenyi István Egyetemen oktatják. A Szent István Egyetemen a 2017/18. tanévtől a Precíziós kertészeti technológiák mint szakdolgozat-készítés szempontjából választható specializáció jelenik meg a Kertészmérnök BSc-képzésen. A duális képzések keretében a hallgatók jelentős gyakorlati tapasztalatot is szerezhetnek a képzési idő alatt. Ilyen képzést hirdet a Miskolci Egyetem Müszaki Földtudományi Kara a KITE Zrt.-vel és hasonló együttműködésben vesz részt az AXIÁL Cégcsoport a Nyíregyházi Egyetem Műszaki és Agrártudományi Intézetével, a Szegedi Tudományegyetem Mérnöki Karával, valamint a Szent István Egyetem Gépészmérnöki Karával. Az utóbbi helyen idén készült el a Helmut Claas Precision Agriculture Laboratory, ahol a gépészmérnök hallgatók megismerkedhetnek a technológiával.

Az Eszterházy Károly Egyetem Gyöngyösi Károly Róbert Campusa folytat Precíziós mezőgazdasági szakmérnök/szaktanácsadó szakirányú továbbképzést, míg a Szent István Egyetem a Mühold alapú helymeghatározás alkalmazása a mezőgazdaságban, valamint az Intelligens járműirányítás a mezőgazdaságban címü 4 napos felnőttképzési kurzusokat hirdeti meg.

A gazdálkodók továbbképzésére a Dr. Szabó Agrokémiai Kft. és az Agromatic Automatizálási Kft. 2015-ben „Döntéstámogatás a precíziós gazdálkodásban” témájú vezetői tréninget szervezett, 2017-ben pedig a KITE Zrt. rendezett „Precíziós gazdálkodás” címmel továbbképzést az érdeklődő szakemberek, a partnergazdaságok vezetői és dolgozói számára, valamint az Agromatic Automatizálási Kft. is indít „Precíziós gazdálkodás a gyakorlatban” címü tanfolyamot. 2017-ben harmadik alkalommal került megrendezésre a PREGA Konferencia és Kiállítás, ahol a vezető vállalatok, valamint hazai és külföldi szakértő előadók mutatták be a precíziós gazdálkodás lehetőségeit és trendjeit.

A 73/2015. (XI. 6.) FM rendelet 1. és 2. melléklete tartalmazza a szaktanácsadás szakterületeit, illetve az azokon belüli támogatható tevékenységeket. Sem az agrárinformatika, sem a precíziós 
gazdálkodás nincs nevesítve, legfeljebb más tevékenységek (pl. szántóföldi növénytermesztés vagy farmmenedzsment) keretében lehet ilyen jellegű szaktanácsadást folytatni.

A szaktanácsadók szerepe meghatározó az új technológiák terjedésében, és ehhez fontos a szaktanácsadók rendszeres képzése is. Hazánkban a névjegyzéki tanácsadóknak a 73/2015. (XI. 6.) FM rendelet szerint kötelező a Nemzeti Agrárgazdasági Kamarához bejelentett és elfogadott szakmai rendezvényeken való részvétel az erre vonatkozó Irányító Hatósági közleményben meghatározottak szerint. A NAK által közzétett szakmai rendezvények listáján 2015-ben 156-ból csupán egy, 2016ban 175-ből három rendezvény kapcsolódott a precíziós mezőgazdaság témakörhöz.

Magyarországon több cég is nyújt szaktanácsadási szolgáltatást a precíziós termesztéssel kapcsolatban, elsősorban a KITE Zrt., az AXIÁL Kft., az IKR Agrár Kft., a Dr. Szabó Agrokémiai Kft. (Jó Gazda Program ${ }^{\circledR}$ ), az Agromatic Kft., a Tomelilla Kft. és a Timac AGRO Hungária Kft. A szaktanácsadás fontosabb témakörei közé sorolható az alapadatbázisok (táblák, inputanyagok, gépadatok) kialakítása, talajmintavétel és tápanyag-gazdálkodási terv elkészítése, a kijuttatási, hozam- és jövedelemtérképek elkészítése, a gépüzemeltetési adatok kiértékelése, helyszíni gépbeállítások és távdiagnosztika használata.

A gépforgalmazók szántóföldi bemutatókat tartanak, illetve általában oktatást is nyújtanak az általuk forgalmazott eszközökhöz. Több cég összefogásával készül az Agronaplóban megjelenő „Zérótól a precíziós gazdálkodásig" cikksorozat, ami szemléletesen mutatja be a precíziós gazdálkodás bevezetésének folyamatát.

A KITE Zrt. kezdeményezésére 2015. novemberében a Debreceni Egyetem Agrártudományi Központja, a Miskolci Egyetem, a John Deere, az Orthman Manufacturing Inc., a Dow AgrosSiences Hungary Kft., a Bayer Hungária Kft., a Pannonia Ethanol Zrt. és a Holstein Genetika Kft. együttmúködési megállapodást írt alá, melynek célja a precíziós gazdálkodás terjesztése Magyarországon. Szintén konzorciumi formában, GINOP-támogatással fejleszti tovább a KITE Zrt. a jelenlegi szaktanácsadási rendszerét, melynek célja egy „üzemmérettől független komplex precíziós szaktanácsadási rendszer kialakítása”. Ennek során a szaktanácsadási folyamatok automatizálását és online, valós idejü szakértői rendszer kialakítását szeretnék megvalósítani (Sulyok, 2016).

\subsubsection{Szabályozás, támogatás}

A precíziós mezőgazdaság szélesebb körü alkalmazása segítheti az élelmiszer-termelés növelését, a környezetkímélö gazdálkodást, az éghajlatváltozáshoz való alkalmazkodást, valamint a mezőgazdasági eredetü üvegházhatású gázok kibocsátásának csökkentését (Underwood et al., 2013) és hozzájárulhat a termésminőség javításához is (Tey és Brindal, 2012).

Phil Hogan (2016), az Európai Bizottság mezőgazdasági biztosa az év elején bejelentette, hogy mintegy 64 millió euró áll majd rendelkezésre a Horizon 2020 2016-2017. évi munkaprogramjában a precíziós gazdálkodás és a digitális mezőgazdasági technológiák támogatására. Ezen belül 30 millió eurót „A mezőgazdaság digitalizációja és az élelmiszer-biztonság” pilotprojekt megvalósítására szánnak. A Horizon 2020 program (EC, 2016) elsősorban a kutatás-fejlesztést támogatja, de mintagazdaságok hálózatával kapcsolnák össze a kutatást és a gyakorlatot.

A gazdálkodók számára jelenleg nincsenek olyan támogatási jogcímek vagy programok, amelyek ösztönöznék a technológia alkalmazását (IVSZ, 2016b). Takácsné György (2015) szerint a 2014-2020 közötti támogatási rendszer jövedelemkompenzációja miatt sok termelő nem is tekinti hangsúlyos kérdésnek a költséghatékonyság növelését. Kiemeli azt is, hogy amíg a helyspecifikus vegyszerkijuttatás környezetterhelés csökkentésében megnyilvánuló előnye nem realizálódik a termelönél és azt nem erősíti a támogatási rendszer, nem várható a tömeges átállás. 
Az Európai Parlament 2016. június 7-i állásfoglalása „Az innováció és a gazdasági fejlődés előmozdításáról a jövőbeli európai mezőgazdasági gazdálkodásban” (2015/2227(INI)) csalódottságának ad hangot a GPS-technológiák lassú terjedése miatt és rámutat arra, hogy az új technológiákat jelentőségteljessé kell tenni a mezőgazdasági termelők számára. Ösztönzi a precíziós mezőgazdaság elterjedését és felszólítja a Bizottságot, hogy számolja fel a precíziós mezőgazdaság alkalmazása előtt álló akadályokat, különösen a bonyolult és nem egységes IKT-rendszerekkel és a beruházási szinthez füződő kérdésekkel kapcsolatosakat.

A pilóta nélküli légi jármüvek - drónok - alkalmazása iránt nagy az érdeklődés, hiszen jól alkalmazhatók a területek heterogenitásának felmérésében. Használatuk jogi szabályozása sehol sem megoldott Európában, de az Európai Repülésbiztonsági Ügynökség megfogalmazott javaslatokat a közös európai szabályozás létrehozására (EASA, 2015), ami várhatóan 2018-ra születik meg. A 150 kg feletti pilóta nélküli légi jármüvek szabályozása európai uniós hatáskörbe tartozik, e súlyhatár alatt a jogszabály kidolgozása tagállami feladat. Magyarországon 2016 decemberében elkészült a drónokkal kapcsolatos kormányrendelet tervezete, ami 2017. július 1-től lépne életbe. A rendelet méret alapján három kategóriába sorolja a drónokat, meghatározza használatuk alapvető feltételeit, az egyes kategóriákhoz kapcsolódóan pedig további részletes szabályokat tartalmaz. Eszerint nyilvántartásba kell venni azokat az eszközöket, amelyek felszálló tömege meghaladja a 2 kg-ot vagy amellyel ellenszolgáltatás fejében végeznek tevékenységet. A drónok müködtetését képzéshez és vizsgához is kötik, valamint kötelező lenne a felelősségbiztosítás. A felhasználás egyszerübbé tétele érdekében a jövőben mobiltelefonos applikáció jelzi a vezető számára, hogy a repülés az adott területen, légtérben és időszakban engedélyezett-e (NFM, 2016). Jelenleg a drónhasználat csak egyedi tevékenységi engedély és eseti légtérengedély birtokában lehetséges, amelyet a Nemzeti Közlekedési Hatóság Légügyi Hivatala ad ki. A három hónapra érvényes tevékenységi engedély díja 19 ezer forint, az eseti légtérengedély pedig háromezer forintba kerül (Neuwald és Tuzson, 2016). Az engedélyezési eljárás normál ügyintézési határideje 21 nap, ami mezőgazdasági alkalmazásoknál sok esetben (pl. kárfelmérés) túl hosszú. Mérökamerás - térképészeti célra is alkalmas - távérzékelés esetén kérelmet kell benyújtani a Magyar Honvédség Geoinformációs Szolgálatához is.

\subsection{Javaslatok}

Ha a közoktatásban nagyobb szerepet kap a környezettudatosság és megnő a lakosság fenntarthatóság iránti elkötelezettsége, az nyomást gyakorol a gazdálkodókra, hogy a precíziós gazdálkodást alkalmazzák. De ez a társadalmi nyomás nem elég, szükséges mellé az ösztönzés is. Ehhez kedvező áron elérhető, személyre szabott információ szükséges a falugazdászokon, illetve szaktanácsadókon keresztül. Számos pénzügyi intézkedés is ösztönző lehet, például beruházástámogatások, kamatcsökkentés és a kiegészítő támogatások (Tey és Brindal, 2012). Aubert et al. (2012) vizsgálata szerint a növényvédőszer- és a mütrágyahasználatra vonatkozó megfelelő szabályozás is erősen képes ösztönözni a precíziós technológia alkalmazását.

A precíziós mezőgazdaság előmozdítása a KAP révén gazdasági, környezetvédelmi és szociális szempontból is indokolható, de el kell kerülni a technológiai nyomást azokon a területeken, ahol az várhatóan nem lenne sikeres (Zarco-Tejada et al., 2014).

\subsubsection{Kutatás, fejlesztés}

A mezőgazdaság termelékenységét és fenntarthatóságát célzó Európai Innovációs Partnerség (EIP-AGRI) keretében egyes prioritást élvezö területeken szakmai csoportokat hoztak létre annak érdekében, hogy hatékony megoldásokat találjanak a felmerülö problémák kezelésére. A 13 fókuszcsoport egyike a precíziós gazdálkodással foglalkozik. Véleményük szerint (EIP-AGRI, 2015):

- A precíziós gazdálkodás során keletkező nagy mennyiségü adat feldolgozásához szükség van a felhasználóbarát információs rendszerek további fejlesztésére. 
- A döntéstámogató rendszerek, valamint technikai megoldások kutatásában nagyobb szerepet kell kapnia a gazdáknak és szövetkezeteknek.

- A precíziós gazdálkodás gazdaságosságának bemutatására kalkulátorokat kell fejleszteni, melyek figyelembe veszik az adott régió, a növénytermesztés és állattenyésztés, valamint a szocioökonómiai jellemzők sajátosságait.

- A kis- és közepes gazdaságok számára olyan eszközök szükségesek, amelyek egyszerüen használhatók, megfizethetők és robusztusak.

A Horizont 2020 program keretében érdemes pályázni a precíziós gazdálkodással kapcsolatos kutatás-fejlesztési lehetőségekre, valamint a mintagazdaságok hálózatában való részvételre. Fontos, hogy a gyakorlatban is hasznosítható kutatási eredményekröl a gazdálkodók folyamatosan értesüljenek.

További fontos lépést jelenthetne, ha a hazai forrású alapkutatási pályázatokban (pl. OTKA) kiemelt szerepet és különálló pályázati forrást kaphatnának a precíziós gazdálkodással, annak egyes elemeivel (pl.: tápanyag-utánpótlás, növényvédelem, talajtan, gépészet) foglalkozó témakörök.

\subsubsection{Oktatás, szaktanácsadás}

A precíziós mezőgazdaság fogalmával a közép- és felsőfokú mezőgazdasági oktatásban minden hallgatónak találkoznia kellene, amire építve további posztgraduális képzéseket lehet indítani. Jó gyakorlat a duális képzések megvalósítása mind középiskolai, mind egyetemi szinten. Jelentős problémát jelent azonban, hogy a mezőgazdasági szakiskolák, de még az agrárképzést folytató egyetemek sem rendelkeznek megfelelő gépparkkal és ahhoz kapcsolódó precíziós és szenzoros technológiákkal, sem olyan szakértőkkel, akik ezen gépek és technológiák müködtetéséhez értenének. Kulcskérdést jelent tehát egyrészt a szakiskolák és egyetemek modern gépekkel, eszközökkel való felszerelése, de még fontosabb, hogy a szakiskolai és egyetemi oktatói gárdának legyen lehetősége a profi, piaci értékesítést végző precíziós szaktanácsadóktól elsajátítani a precíziós géphasználat és az ahhoz kapcsolódó gazdálkodás alapjait.

A gazdálkodóknak rövid kurzusokat kell szervezni egy-egy konkrét témakörre vonatkozóan. Erre jó példa az angliai Harper Adams University, ahol a Nemzeti Precíziós Gazdálkodás Központ keretében egynapos bevezető kurzusokat tartanak. Hasonló kurzusokat szervez - részben az említett egyetemmel közösen - az ARTIS képzési központ is. A teljesítésről igazolást állítanak ki, valamint továbbképzési pontok szerezhetők, amik egyes szakmai szervezetekben a tagok számára kötelezőek.

Az i-Cell (2016) felmérése szerint a hazai gazdák 50 százaléka lenne hajlandó technológiai képzéseken részt venni, további 38 százalékuk pedig csak akkor, ha mindez nem járna komolyabb költségekkel. Ezért szükség lenne a humánerőforrás fejlesztését támogató programokra (IVSZ, 2016b).

Magyarországon is rengeteg cikk és előadás található az interneten a precíziós gazdálkodás témakörében, de könnyü elveszni az információk közt. Érdemes lenne egy olyan oldalt létrehozni, ahol egy helyen, hivatalos forrásból juthat információhoz az érdeklődő. Az oldal létrehozását és működtetését célszerüen a Nemzeti Agrárgazdasági Kamarának kellene koordinálni. Jó példa az alabamai szaktanácsadási rendszer, amit az Alabama A\&M University és az Auburn University müködtet. A szabadon elérhető kilenc videotananyag az alabamai szójatermesztők, valamint a búza- és takarmánygabona-termesztők szövetségének támogatásával készült, ezen kívül a szaktanácsadók számos publikációja és előadásának anyaga is elérhető.

A technológia terjedésében nagy szerepe van a jól képzett, független tanácsadóknak. A szaktanácsadók továbbképzési listáján több precíziós gazdálkodáshoz kapcsolódó rendezvényt lehetne szerepeltetni, és nemcsak előadásokat, hanem technikai, illetve gépbemutatókat is. 
A 73/2015. (XI. 6.) FM rendeletet módosítani kell, hogy az agrárinformatika, illetve precíziós gazdálkodás önálló tevékenységi területként szerepeljen. Ennek megfelelően a szaktanácsadási területekhez kapcsolódó végzettségeket is át kell gondolni.

Az európai mezőgazdasági vállalkozók és szövetkezetek érdekvédelmi szervezete, a Copa Cogeca kiemeli, hogy a megfelelő informatikai képzések nemcsak az új technológiai lehetőségek kihasználásában segítik a gazdálkodókat, hanem ezáltal megértik a jogaikat és felelősségüket az új digitális világban. Ha megismerik a lehetséges előnyöket és kockázatokat, akkor nyitottabbá válnak az adatok megosztására is (Copa - Cogeca, 2016a).

\subsubsection{Támogatások}

Az Európai Mezőgazdasági Gépforgalmazók Szövetsége (CEMA, 2015) azt javasolja, hogy a KAP I. és II. pillére legyen rugalmasabb és tegye lehetővé a precíziós mezőgazdaság támogatását. A CEMA arra ösztönzi az uniós döntéshozókat, hogy újra hozzanak létre a korábbi KAP (20072013) 68-69-es cikkéhez hasonló mechanizmust, ami lehetővé teszi a tagállamoknak, hogy az I. pillér költségvetési keretének 10 százalékát a mezőgazdasági üzemek termelékenységének javítását célzó projektekre használják fel. Javasolják egy mezőgazdasági termelékenységbónusz bevezetését is, vagyis azok jutalmazását, akik a kölcsönös megfeleltetés követelményeinek szigorú betartása mellett képesek növelni termelékenységüket. Ez az új zöldítési rendszer része lehetne.

A precíziós gazdálkodás lehetőségeit áttekintő EU-s tanulmány (Zarco-Tejada et al., 2014) rámutat, hogy az Európai Parlament és a Tanács 1305/2013/EU (2013. december 17.) rendelete szerint a II. pillér is több lehetőséget biztosít a tagállamok számára a precíziós gazdálkodás támogatására a Vidékfejlesztési Programon keresztül:

- 17. cikk - Beruházások tárgyi eszközökbe. Az intézkedés célja a mezőgazdasági üzemek korszerüsítése és hatékonyabbá tétele, társfinanszírozás révén segítheti a precíziós technológiát.

- 28. cikk - Agrár-környezetvédelmi és éghajlattal kapcsolatos müveletek. Olyan gazdálkodóknak ítélhető oda, akik önkéntes alapon vállalják az agrár-környezetvédelmi és az éghajlatváltozáshoz kapcsolódó kötelezettségvállalások közül egy vagy több teljesítéséböl álló mủveletek elvégzését, ezzel környezeti szempontból fenntarthatóbb gazdálkodási rendszer folytatását. A precíziós gazdálkodás megfelelő indoklás az intézkedéshez.

- 35. cikk - Együttmüködés. Legalább két szereplő részvételével megvalósuló együttmüködési formák támogatása. Az együttmüködés többek közt lehet kísérleti projekt, új gyakorlatok és technológiák fejlesztése, kis gazdasági szereplők között az eszközök és források megosztása, az éghajlatváltozáshoz való alkalmazkodás vagy a hatékony vízgazdálkodásra irányuló közös megközelítés. A precíziós mezőgazdaság hozzájárulhat ezeknek a követelményeknek a teljesítéséhez, a közös géphasználat pedig elősegítheti a beruházási költségek csökkentését.

A II. pillér lehetőséget nyújt a versenyképesség javítására a szaktanácsadási rendszeren, valamint képzési és innovációs programokon keresztül is. Ez különösen fontos a precíziós gazdálkodás szempontjából.

- 14. cikk - Tudásátadás és tájékoztatási tevékenységek. A szakképzéshez és a készségek elsajátításához kapcsolódó tevékenységek magukban foglalhatnak tanfolyamokat, szakmai találkozókat, üzemlátogatásokat és személyre szabott szaktanácsadást is. Ez megkönnyítheti a precíziós gazdálkodással kapcsolatos tapasztalatok megosztását és előmozdíthatja a technológia terjedését.

- 15. cikk - Tanácsadási szolgáltatások, üzemvezetési és helyettesítési szolgáltatások. Az intézkedés lehetővé teszi, hogy a termelők a gazdasági és környezeti teljesítmény javítása érdekében tanácsadási szolgáltatást vegyenek igénybe. A precíziós gazdálkodás e célokat is szolgálja, így az ehhez kapcsolódó szaktanácsadás, valamint a tanácsadók továbbképzése beilleszthető a támogatott tevékenységek közé. 
Fontos lenne, hogy beruházási támogatást ne csak gépbeszerzésre lehessen igénybe venni, hanem a precíziós gazdálkodáshoz szükséges eszközök, szenzorok beszerzésére is.

Támogatási példaként szolgálhat az amerikai Mezőgazdasági Minisztérium (USDA) által létrehozott Precíziós Gazdálkodást Ösztönző Rendszer, ami a Környezeti Minőséget Ösztönző Program (EQIP) része. A programban azok vehetnek részt, akik még nem alkalmazzák a differenciált tápanyagkijuttatást vagy növényvédelmet, vagy a 4 meghatározott szint közül az első három valamelyikénél tartanak, és szeretnének magasabb szintre lépni. A precíziós tápanyag-kijuttatást és növényvédelmet ugyanazon területen használók esetén 200 acre (kb. 80 ha), külön-külön alkalmazva összesen 400 acre területre kapható két évre támogatás. A szerződéseket azonban 3 évre kötik, a két év támogatás után egy év fenntartás szükséges. A támogatás mértéke a gyakorlat szintjétől függően 8-22 USD/acre (kb. 5600-15 $400 \mathrm{Ft} / \mathrm{ha}$ ). A megvalósítást a kijuttatási tervekkel és a rögzített kijuttatási adatokkal kell igazolni.

Kis gazdaságok esetén a megfelelő fedezeti méret eléréséhez együttmüködésre van szükség. Takács és Baranyai (2010) szerint a kormányzatnak ösztönöznie kell a közös géphasználat szervezeti kereteit biztosító úgynevezett virtuális üzemek létrehozását és működését.

\subsubsection{Adatpolitika}

A Digitális Agrár Stratégia (IVSZ, 2016b) javaslatai közt szerepel a nemzeti adatvagyonhoz való hozzáférés korlátozásának feloldása. A termelők számára szükséges adatokhoz (időjárás, növényvédelem, térképészet, piaci információk stb.) való hozzáférés a termelői döntéshozás javítását szolgálja, így közvetlen hatékonyságnövelő eszköz, az ilyen adatokat elöállító szervek állami finanszírozása pedig egyfajta termelői támogatásként fogható fel. A precíziós gazdálkodás szempontjából a térinformatikai alapadatok (pl. kataszter) és a környezeti adatok elérhetősége lenne kiemelten fontos.

A precíziós gazdálkodáshoz kapcsolódó szoftverek lehetővé teszik a munkafolyamatok és a felhasznált anyagok dokumentálását és azokból a gazdálkodási napló létrehozását. Az automatikus adatrögzítés biztosítja, hogy a gazdálkodók valós adatokat szolgáltatnak a szakigazgatási szerveknek. A szenzorok adataira támaszkodó, a növény aktuális állapotának megfelelő helyspecifikus müvelésmód környezetkímélő hatása bizonyított. Ezek alapján szóba jöhet egyes tápanyag-gazdálkodási szabályok - például maximálisan kijuttatható nitrogén - felülvizsgálata, és indokolt esetben a precíziós gazdálkodók számára nagyobb dózis vagy eltérő időpont engedélyezése.

A precíziós gazdálkodás során rengeteg olyan georeferált parcellaszintủ adat képződik, amelyeket a környezeti kutatásokban, a növénytermesztési modellek fejlesztésében, a hozam-elörejelzésben, illetve az agrár-szakigazgatási ügyintézésben és döntéshozatalban is hasznosítani lehetne. Például a 61/2009. (V. 14.) FVM rendelet az agrár-környezetgazdálkodási támogatások igénybevételének feltételei közt meghatározza a talajmintavétel során betartandó követelményeket, beleértve a mintavételi helyek kiválasztását is. Ha a rendelet kiegészülne azzal, hogy a mintavételi helyeket pontos koordinátákkal kell megadni (precíziós mintavétel), könnyebben ellenőrizhető lenne a követelmények betartása. A pontos mintavételi helyek és a hozzájuk kapcsolódó talajvizsgálati eredmények jól kiegészíthetnék a Talajvédelmi Információs és Monitoring (TIM) rendszert is.

Egy ilyen jellegű adatgyüjtés, tárolás és feldolgozás módszertanát azonban még ki kell dolgozni, tisztázni kell, hogy ki ellenőrzi az adatokat és ki a tulajdonosuk (Zarco-Tejada et al., 2014; EIPAGRI, 2015). Olyan adatpolitikára van szükség, ami szem elött tartja a gazdálkodók és adataik védelmét, ugyanakkor lehetővé teszi az adatok megosztását és felhasználását. Ehhez az adatelemzéssel foglalkozó vállalatoknak, a döntéshozóknak és a gazdálkodóknak együtt kell müködniük (Zeigler és Steensland, 2015). 
Az American Farm Bureau (2016) kezdeményezésére 37 vállalat és termelői szervezet - köztük a Dow AgroScience, a DuPont Pioneer, a John Deere és a Syngenta - 2016 márciusában már aláírt egy állásfoglalást a precíziós gazdálkodás során keletkező adatok használatáról. E szerint a termelés során keletkező adatok tulajdonosa a gazdálkodó, az ő felelőssége, hogy megegyezzen az adatok megosztásáról és felhasználásáról a többi érintett féllel, mint például bérlö, szövetkezet, hardver- és szoftverszolgáltatók. A szolgáltatók csak a termelő kifejezett hozzájárulása esetén használhatják fel az adatokat, amit szerződés formájában rögzíteni kell. Az adatok gyüjtéséről és felhasználási módjáról értesíteni kell a termelőket, valamint meg kell adni, hogy kivel vehetik fel a kapcsolatot, ha bármilyen kérésük vagy panaszuk van az adathasználattal kapcsolatban. El kell magyarázni, hogy mi a hatása annak, ha engedélyezi vagy nem engedélyezi a felkínált szolgáltatásokat. A szolgáltató nem adhat tovább és nem hozhat nyilvánosságra egyedi adatokat a termelő engedélye nélkül. Lehetővé kell tenni, hogy a gazdálkodó az adatgyüjtés szüneteltetését kérje, illetve kérésére biztosítani kell a meglévő adatok eltávolítását, megsemmisítését.

A Copa - Cogeca (2016a) is nagy kihívásnak tartja a növekvő adatmennyiség kezelését, mivel a különböző típusú mezőgazdasági adatok eltérő tulajdonosi és adatvédelmi szintekhez vezetnek. Egyetért abban, hogy a gazdálkodó által gyüjtött adat a gazdálkodóé, fontosnak tartja az adatok tulajdonjogának védelmét, valamint azt, hogy a gazdálkodó korrekt részesedést kapjon az adatainak felhasználásával keletkező értékekből. Elismeri, hogy az adatokat nem lehet ugyanúgy birtokolni, mint a fizikai eszközöket, ezért alapvető fontosságú, hogy rögzítsék a mezőgazdasági adatok elérésére és felhasználására vonatkozó alapelveket. Az amerikai farmerszervezethez hasonlóan úgy gondolja, hogy az adatok gyüjtése és felhasználása csak a gazdálkodók engedélyével és a velük kötött, érthetően megfogalmazott szerződések alapján történhet. Az elemzésekhez szükség van az egyedi adatokra, de biztosítani kell a gazdálkodókat arról, hogy az adataik az engedélyük nélkül nem kerülnek ki harmadik félhez, például biztosítótársaságokhoz vagy a hatóságokhoz.

Bármilyen adatcsere során a rendszerek ki vannak téve támadásoknak. A Copa - Cogeca felszólítja a Bizottságot és a tagállamokat, hogy az informatikai cégekkel együttmüködve vegyenek részt az adattárolás és a hálózati biztonság módszereinek kidolgozásában. A gazdálkodók egyre nagyobb mértékben használják a felhőszolgáltatásokat, ezért szorgalmazzák az ezzel kapcsolatos EU-s szabályozási környezet kialakítását is.

A drónok használata nemcsak repülésbiztonsági, hanem adatvédelmi problémákat is felvet. A Copa - Cogeca (2016b) szerint a vidéki nyílt területeken a biztonsági és/vagy adatvédelmi kockázat jóval alacsonyabb, mint a városokban, míg a technológia potenciális előnye jelentős, ezért egyszerü intézkedések bevezetését javasolják. Ugyanakkor elismerik, hogy a növény- vagy állatállományról illetéktelen személy által készített felvételek adatvédelmi aggályokra adnak okot, és például tisztességtelen árszabályozáshoz vezethetnek, ami ellen fel kell lépni a szabályozáson keresztül.

Az EU nemrég módosította a személyes adatok védelméről szóló rendeletet (EU, 2016), és vannak irányelvek a számítógépes programok védelméröl is (EK, 2009). Szükség lenne a termelés során keletkező adatok felhasználásával és védelmével kapcsolatos szabályozás megalkotására és bevezetésére is. 


\section{0. Összefoglalás}

\section{A precíziós szántóföldi növénytermesztés összehasonlító vizsgálata}

Kemény Gábor (szerk.), Lámfalusi Ibolya (szerk.) és Molnár András (szerk.)

\subsection{Megállapítások}

1. A precíziós és a talajkímélő gazdálkodás szántóföldi növénytermesztésben való elterjedtségére és alkalmazásuk körülményeinek vizsgálata céljából kérdőíves felmérést végeztünk, amely az AKI tesztüzemi rendszerben szereplő közel 1000 szántóföldi növénytermesztő üzem körében valósult meg. A kérdöívre 656 üzem adott választ, az AKI tesztüzemi rendszerben nyilvántartott szántóföldi növénytermesztő üzemek mintegy 70 százaléka, mely mintavétel reprezentatívnak minősül.

2. A válaszadók szinte valamennyien hallottak a precíziós és a talajkímélő technológiákról, előbbinél a legjelentősebb kommunikációs csatornának a nyomtatott szakmai lap bizonyult, míg utóbbiról elsősorban más gazdálkodótól hallottak a megkérdezettek. A gazdálkodók többnyire (86 százalékuk) elismerik a technológiák környezeti és gazdasági fenntarthatósághoz való hozzájárulását.

3. A gazdálkodói percepciók kimutatása érdekében folytatott kérdőíves felmérés eredményei igazolták azt a hipotézisünket, hogy a termelök mindkét technológia terjedésének legnagyobb gátját a magas beruházási költségekben látják. A válaszadók szerint elterjedésüket leginkább az alkalmazás hatására realizálható magasabb jövedelmezőség segítené elő, de a termelők számára nyújtott több, illetve részletesebb információ is nagy jelentőséggel bírna, valamint ha a technológia alkalmazását az agrárirányítás valamilyen formában támogatná.

4. A precíziós technológiát az első üzem (a válaszadók körében) 2004-ben kezdte el alkalmazni. A technológia terjedését kezdetben lassú felfutás jellemezte 2012-ig, azt követöen lényegesen dinamikusabbá vált a folyamat, különösen 2014-ben és 2015-ben vezették be egyre többen a precíziós technológiát. Általában véve az alkalmazott technológiai elemek közül a precíziós talajminta-vételezés, valamint a tápanyag-kijuttatási terv készítése a leggyakoribb.

5. A kérdőíves felmérés alapján a növénykultúrák közül az őszi búza mind a müvelt terület mérete, mind a termesztők száma tekintetében élen jár a precíziós technológia alkalmazásában, majd azt követi a kukorica, a napraforgó és a repce.

6. A precíziós technológia hatásaival összefüggésben a betakarított növénykultúrák hozamában történt változás értékelésekor legtöbben kisebb mértékü növekedésről számoltak be, nagyobb mértékü növekedésről mindössze az üzemek 13,3 százaléka nyilatkozott. A válaszadók 31,1 százaléka szerint a precíziós technológia a fajlagos költségben kismértékü csökkenést eredményezett, további 20,0 százalékuk jelentősebb mértékü csökkenést realizált, míg szintén 20,0 százalékuk kisebb mértékü növekedésről számolt be. A jövedelmezőség tekintetében egyértelmübb volt a pozitív hatás, a válaszadók több mint fele a fajlagos jövedelmezőség kismértékü növekedéséről adott számot, míg 8,9 százalékánál nagyobb mértékü növekedés következett be a technológia hatására. A válaszadók 11,1 százaléka kismértékü, 6,7 százaléka pedig jelentős csökkenést tapasztalt.

7. A talajkímélő művelés hatásai a megkérdezettek szerint korlátozottabbak a precíziós gazdálkodásénál. A hozam tekintetében a talajkímélő müvelést végzők több mint egyharmada nem tapasztalt változást, 29,5 százaléka pedig kisebb mértékü növekedést figyelt meg, továbbá 
viszonylag sokan számoltak be a hozam kisebb mértékü csökkenéséröl is. A jövedelmezőséget illetően a válaszadók csak kevesebb mint fele támasztja alá annak növekedését, 22,3 százalékuk nem észlelt változást a művelés hatására, kisebb mértékü csökkenést a gazdálkodók 13,4 százaléka tapasztalt. Az egy hektárra jutó költség (fajlagos költség) a gazdálkodók 44,6 százalékánál csökkent, 18,8 százalékánál pedig jelentős mértékü volt a ráfordításokban jelentkező megtakarítás.

8. A művelés munkaerő-felhasználásra gyakorolt hatásáról megoszlottak a vélemények. Közel azonos mértékben tapasztaltak kismértékü növekedést és változatlanságot. A válaszadók legnagyobb része (25,9 százaléka) jelentősen kevesebb munkaerővel gazdálkodott, 23,2 százalékánál kisebb mértékben jelentkezett a csökkenés.

9. A precíziós technológia elönyeinek igazolását többféle módon is igyekeztünk elvégezni, ezek között a kérdöíves felmérésre adott válaszokon túl szerepelt a precíziós eszközök egyik meghatározó hazai forgalmazójának, a KITE Zrt.-nek a megkérdezése, illetve a technológiákat alkalmazók adatainak a hagyományos üzemekkel való összehasonlítása összesen négyféle változatban.

10. A tanulmány egyik fontos erénye, hogy a precíziós technológia előnyei a Közös Agrárpolitika eredményességének bemutatására használt, ötvenéves múltra visszatekintő FADN-adatbázison kerülnek kimutatásra. Ez lényeges elem úgy szakpolitikai szempontból, mint a termelői döntéshozatal oldaláról, mivel a tesztüzemi rendszerben szereplő gazdaságok olyan mintaként tekinthetők, amelyek megfelelően képesek reprezentálni a meghatározó árutermelő gazdálkodókat.

11. A vizsgálatok eredményeit összegezve megállapítható, hogy a búza hozamánál 7-17 százalékos, a kukoricánál 2-9 százalékos, a napraforgónál 6-10 százalékos többletet eredményez a technológiaváltás, miközben a repcénél és az őszi árpánál nem sikerült a rendelkezésre álló adatok birtokában ilyen megállapítást tenni.

12. A termelési érték tekintetében magasabbak az említett arányszámok, a búzánál 8-38 százalékos, a kukoricánál 11-42 százalékos, a napraforgónál 3-32 százalékos többletérték mutatkozik. A többletértéket jellemző, esetenként széles intervallumokat az magyarázza, hogy a precíziós technológia előnyei nagyban függenek az adott év időjárásától, a talajadottságoktól, valamint a gazdálkodás színvonalától. A helyspecifikus gazdálkodás előnyei elsősorban a kedvezőtlenebb adottságú időszakokban és területeken mutathatók ki, ahol a hagyományos müveléssel a hozampotenciálhoz viszonyítva csak korlátozott eredmények érhetők el.

13. A precízebb technológia, a ráfedés- és kihagyásmentes müvelés eredményeként általában véve azt várnánk, hogy az áttéréssel csökken az inputfelhasználás. Vizsgálataink ennek éppen az ellenkezőjét támasztották alá, a hozamokhoz hasonlóan az inputfelhasználás szintjében is jellemzően többlet mutatkozott. A búzánál -3 és +47 százalék, a kukoricánál -5 és +30 százalék, a napraforgónál -8 és +26 százalék között változott az egy hektárra vetített termelési költség a hagyományos technológiához képest.

14. Az önköltség tekintetében már valamivel alacsonyabbak a precíziós technológia többletráfordításai, sőt a ráfordítások csökkenése is nagyobb eséllyel következhet be. Ez magától értetődő, hiszen hozamnövekedés történik, amelynek eredménye, hogy a termékegységre eső költség mérséklődik. A búzánál -17 és +29 , a kukoricánál -13 és +22 , a napraforgónál -17 és +20 százalék közötti különbség mutatható ki a szántásos müveléshez képest.

15. Amennyiben a ráfordítások növekedését a termelési érték növekedése meghaladja, úgy javul az ágazat jövedelme. A búzánál és a napraforgónál vizsgálataink szerint ez egyértelműen így alakul, előbbinél 23-123 százalékos többletjövedelem, utóbbinál 28-52 százalékkal nagyobb eredmény realizálható. A kukoricánál nem minden esetben következett be jövedelemnöve- 
kedés, így itt előfordulhat akár a 17 százalékos kiesés, de akár a 105 százalékkal magasabb jövedelem is.

16. A rendelkezésünkre álló adatok birtokában ágazati szinten becsléseket végeztünk a precíziós tevékenységre való áttérés makroszintü hatásaira. Megnéztük, hogy hogyan alakul ágazati szinten a hozam, a termelési érték, a termelési költség és az ágazati eredmény, amennyiben a vizsgált üzemekhez hasonló paraméterekkel (termelési költség, vetésterület mérete) bíró üzemek - amelyeknél igazolni tudtuk az előnyöket - végrehajtják a technológiaváltást.

17. A kiválasztott üzemek áttérésével a jövőbeni precíziós területek a vizsgálatba vont szántóföldi növények teljes 2,9 millió hektárnyi vetésterületéből 1,4 millió hektárt, azaz 46,9 százalékot tennének ki. A búza esetében a precíziós területek a teljes búzatermő terület 59 százalékát, kukoricánál a teljes kukoricatermő terület 40 százalékát, napraforgónál a teljes napraforgó-terület 38 százalékát jelentenék. Az őszi árpa és az őszi káposztarepce precíziós technológiával művelt területe külön-külön 15-17 százalékát adná a két ágazat összes vetésterületének.

18. A precíziós gazdálkodásra áttért több mint 21 ezer üzem 2,4-6,0 százalékkal nagyobb (+342,7858,9 ezer tonna) termésmennyiséget produkálna a vizsgált növényeknél az országos 14,3 millió tonna termésmennyiséghez képest. A termelési érték az öt növénykultúránál együttesen a jelenlegit 32,0-142,0 milliárd forinttal múlná felül, azaz az értékük 826,2-936,2 milliárd forintot jelentene.

19. A termelési költségek összességében 606,2 milliárd forintról 10,4 milliárd forinttal 595,9 milliárd forintra csökkennének, amennyiben az általunk kiválasztott üzemek precíziós gazdálkodásra váltanának. Ezen belül a vetőmagköltség 2,4 milliárd forinttal csökkenne, a mütrágyaköltség 3,8 milliárd forinttal emelkedne, a növényvédőszer-költség 1,8 milliárd forinttal mérséklődne.

20. Az ágazati eredmény a precíziós gazdálkodásra váltók esetében jelentősen, 15,2-88,5 milliárd forinttal bővülne, azaz 187,9 milliárd forintról 203,1-276,4 milliárd forintra emelkedne.

21. A becslés zárásaként azt is megvizsgáltuk, hogy hogyan alakulna a beruházási költség a technológiát váltó üzemeknél. Az eszközállomány elhasználódottsága alapján egyes üzemeknél komplett gépparkcserét feltételeztünk, másoknál a precíziós eszközökkel való felszerelést láttuk indokoltnak, megint másoknál szerkezeti elemek és precíziós szoftverek beszerzését. A beruházási költség a három kategóriában együttesen mintegy 325 milliárd forint, melynek legnagyobb részét (mintegy 300 milliárd forintot) a teljes gépparkcsere adja.

22. A másik két kategóriánál számításaink igazolták, hogy a gazdálkodóknak - az 1000 ha alatti és feletti területtel rendelkezőknek egyaránt - mind a szerkezeti elemekkel és szoftverekkel történő felszerelés, mind pedig a precíziós eszközökkel való felszerelés megéri, mert annak költsége bőven megtérül a technológia eredményeként keletkező többletjövedelmekben. A megtérülés egyedül a teljes gépparkcserénél nem igazolódott. Ennek kapcsán azonban meg kell jegyezni, hogy mivel a gépek az üzem teljes területén használatosak, illetve nemcsak a többleteredmények elérésében játszanak szerepet, így nem is várható a beruházási költségüknek a precíziós többletjövedelmekben való megtérülése. Ugyanezen üzemeknél a precíziós eszközökkel való felszerelés már gazdaságosnak bizonyult.

\subsection{Következtetések}

1. A technológia elterjedésének legfőbb gátjaként a kutatásban részt vevő precíziós gazdálkodók a jelentős beruházásigényt azonosították. Ezt követte a tudás, az ismeretek hiánya, illetve az új ismeretek elsajátításától való félelem. Ennek jelentőségét jól mutatja, hogy a technológia elterjedését támogató tényezők között az információk, ismeretek megosztása a többletjövedelem mellett másodikként szerepelt a válaszok száma alapján. A megfelelő ismeretek, a technológia 
biztos kezelésének képessége a mélyinterjúkban is kulcstényezőként szerepelt a precíziós technológia sikeres alkalmazásának kritériumai között. Figyelembe véve a technológia által realizálható makrogazdasági hatásokat - úgymint a többlettermés, többlethozam és -jövedelem -, a precíziós technológia elterjedését az agrárirányításnak is érdemes volna prioritásként kezelnie.

2. A precíziós technológia eredményes alkalmazásához nem elegendő a precíziós képességekkel rendelkező erő- és munkagépek beszerzése, illetve a megfelelő inputanyagok felhasználása. Nem homogén technológiáról van szó, amely bármely körülmények között ugyanúgy müködik, hanem az egyes technológiai müveleteket a helyi természeti adottságokhoz (pl.: talajadottságok, domborzati viszonyok) szükséges adaptálni. A kívánatos eredmények eléréséhez komoly szakismeretekre van szükség, mindenképpen szaktanácsadás mellett javasolt a technológia bevezetése. A remélt előnyök megjelenése is a technológia megfelelő alkalmazását követően várható.

3. A technológia hatására növekvő inputfelhasználás - amely a szakirodalommal egyébként összecsengő megállapítás - magyarázata, hogy Magyarországon az inputfelhasználás szintje egyébként is jellemzően alacsony, így modern müvelési módra való áttéréssel a kívánatos hozamok elérése érdekében az inputfelhasználás intenzitását növelni szükséges. Ez egyben azt is jelenti, hogy az inputforgalmazóknak is érdeke a technológia terjesztése.

4. A kutatás során arra a megállapításra jutottunk, hogy jelenleg nincs egységesen kialakult szabályrendszer a technológia alkalmazását illetően, amelyet ha a gazdálkodó adaptál, úgy mindenképpen realizálja a várt előnyöket. Kellő tapasztalat hiányában még nincsenek meg a környezeti és gazdasági optimumok: meddig érdemes növelni az inputanyag-felhasználás mértékét a jobb minőségü talajokon, illetve miként juttassák ki az inputanyagokat a rosszabb termőképességgel rendelkező területekre, azaz növeljék-e az inputok mennyiségét, avagy a minimálisra csökkentsék azt. Az egységes ,,szabály” kialakítása az elkövetkező kutatások témája.

\subsection{Javaslatok}

1. A precíziós gazdálkodás alapja a megfelelő humán tőke. A növénytermesztésben már most olyan munkavállalókra van szükség, akik megfelelő képzettséggel rendelkeznek és képesek a precíziós eszközöket működtetni, ez azonban a jövőben még inkább így lesz. Mivel Magyarországon a növénytermesztésben tevékenykedő munkavállalók képzettsége jellemzően alacsony, ezáltal célszerủ az oktatást a jövőben várható nagyfokú magas képzettségü munkaerö-szükségletnek megfelelően változtatni. Ennek érdekében javasolt a mezőgazdasági szakiskolák és az agrárképzést is nyújtó egyetemek oktatóinak képzése piaci szolgáltatást nyújtó precíziós szaktanácsadók által. Fontos a szakiskolák és az egyetemek felszerelése a precíziós gazdálkodásra alkalmas gépekkel, szenzorokkal és szoftverekkel, amelyek működtetéséhez szintén igénybe kell venni a piaci precíziós szaktanácsadási segítséget. Tovább kell erősíteni a duális képzés szerepét, ahol kiemelt figyelmet kell kapniuk a precíziós gazdálkodást végző termelőknek.

2. Nemzeti forrásból elkülönített alapot kell biztosítani a precíziós gazdálkodással foglalkozó, azt témájául választó alap- és alkalmazott kutatási témáknak, mely utóbbiak esetében törekedni kell a technológiát a gyakorlatban használó kulcsszereplők (termelők, szaktanácsadók, gépgyártók, informatikai vállalkozások) szoros bevonására. Ezáltal biztosítható, hogy a kutatási források gyakorlati problémák megoldását segítsék elő, és a hazai agrár- és gépipari, valamint informatikai vállalkozások növekedésnek indulva képesek legyenek betörni a jövőben várhatóan drasztikusan bővülő, a mezőgazdasági digitalizációhoz köthető réspiacokra.

3. Jogszabályi háttérrel kell biztosítani a precíziós gazdálkodás minél zökkenőmentesebb fejlödését. Ezen belül biztosítani kell, hogy a precíziós gazdálkodás során keletkező adatállományokról a termelők rendelkezhessenek, azokat a gépgyártóktól, illetve az adatok rögzítőitől megkaphassák, és azokat hazai kutatási célokra is fel lehessen használni. Lehetővé kell tenni 
a modern technológiák életszerü használatát (pl. drónok repülésének engedélyezése), illetve kötelezővé kell tenni a technológia alapját képező talajminta-vételezés precíziós helymeghatározását, illetve külső szakértő általi validálását. Ki kell alakítani az állami adatbázisokban tárolt termelöi, illetve táblaszintű adatok jogosultságkezelését (pl.: örökös, vevő vagy új bérlő hozzáférhessen a tábla korábbi adataihoz).

4. A nagyobb inputfelhasználás és a környezeti fenntarthatóság nem áll ellentétben egymással, ugyanis precíziós kijuttatással (a megfelelő inputot a megfelelő kultúrának, a megfelelő időpontban és fizikai helyen) a tápanyagot a növény teljes egészében képes felvenni és hasznosítani, ezáltal környezeti károsodás nélkül folyhat a termelés. Ezt figyelembe véve a precíziós gazdaságok számára a környezeti határértékek is megemelhetök lehetnének oly módon, hogy aki igazoltan precíziós gazdálkodást végez, az magasabb hatóanyagdózisokkal dolgozhasson, mivel a pontos inputanyag-kijuttatás hatékonyabb hasznosulással és kisebb káros kimosódással jár.

5. Amennyiben a hazai és/vagy az uniós támogatási rendszer - szubvenciók vagy akár visszatérítendő támogatás, kamattámogatott hitel formájában - forrást biztosítana a gazdák számára a precíziós technológiai elemek adaptálására, a helyspecifikus módon végzett gazdálkodás vélhetően intenzívebb terjedésnek indulna Magyarországon. Mivel a precíziós gazdálkodás hozzájárul a környezeti fenntarthatósághoz, akár a Vidékfejlesztési Program Agrár-környezetgazdálkodási Programján keresztül is igényelhetnének a gazdálkodók a technológia bevezetéséhez szükséges forrást.

6. A kérdőíves felmérések, valamint a kapcsolódó vizsgálatok megismétlése szükségszerü néhány éven belül, hiszen a technológiát bevezető üzemek száma folyamatosan nő, illetve az alkalmazás „mélysége” is várhatóan javul. A jelenlegi kutatási eredmények a technológia felfutási szakaszában keletkeztek, így könnyen előfordulhat, hogy néhány év múlva markánsabb eredmények mutathatók ki. 



\section{Summary}

\section{Comparative study of precision arable crop production}

KEMÉNY, Gábor (eds.), LÁMFALUSI, Ibolya (eds.) and MOLNÁR, András (eds.)

\subsection{Findings}

1. The aim of our questionnaire was to examine the penetration and the conditions of precision and conservation tillage farming. This survey was completed among almost 1000 arable Farm Accountancy Data Network (FADN) system farms run by the Research Institute of Agricultural Economics (AKI). Respond was given by 656 farms which is about 70 per cent of the total registered arable crop plants in the FADN system so the sampling can be considered as representative.

2. Almost all respondents heard about precision and conservation tillage technologies. In case of precision farming printed professional journals proved to be the most important communication channel, while in case of conservation tillage farming the interviewed mostly heard about it from other farmers. Farmers mainly ( 86 per cent) acknowledge the technologies contribution to environmental and economic sustainability.

3. The results of survey which was conducted to establish farmers' perceptions proved our hypothesis that greatest barrier to the spread of both technologies is high investment costs. According to the respondents the uptake of these technologies could be increased mainly by proven higher profitability of application. Besides this more or detailed information to the farmers would be important and if the technologies would be supported by agricultural management in some form that could result widespread adaption.

4. The first farm (among respondents) started to use precision technology in 2004. The uptake of this technology is initially characterized by a slow growth until 2012. After that the rise became significantly more dynamic, particularly in 2014 and 2015 started to introduce precision technology. Generally precision soil sampling and nutrient application maps were the most common among technological elements used.

5. On the basis of the questionnaire among arable crops winter wheat is most frequently subject of the use of precision technology both from the point of size of cultivated area and number of producers, which is followed by corn, sunflower and rape.

6. Farms applying precision technology reported minor yield increase and only 13.3 per cent reported larger increase. According to 31.1 per cent of the respondents, precision technology resulted slight decrease in unit cost. Further 20.0 per cent of them realized more significant decrease, while also 20.0 per cent gave an account of slight increase. In case of profitability the positive impact was more unequivocal, more than half of the respondents reported on slight rise of unit profitability, while greater increase was occurred by impact of the technology by 8.9 per cent of the farmers. 11.1 per cent of the respondents experienced slight, 6.7 per cent significant decline in profitability.

7. According to the respondents the impacts of conservation tillage farming is more limited than the effects of precision farming. More than third of them reported no change in yields, while 29.5 per cent of respondents observed slight increase. Moreover, relatively large number of farmers gave an account of slight decline of yield. Considering profitability, less than half of respondents gave countenance to increase that, 22.3 per cent did not realized any change and 
slight decrease was experienced by 13.4 per cent of the farmers. The costs per hectare (unit cost) decreased by 44.6 per cent of the producers. Input savings was significant by further 18,8 per cent of the farmers.

8. Opinions varied about the effect of precision cultivation on labour use. Those Almost equally farms experienced a slight increase and no change. Most respondents (25.9 per cent) used significantly less labour, by 23.2 per cent decline was slightly.

9. In order to reveal advantages of precision technology several approaches were used. Beyond the questionnaire survey answers we interviewed the KITE Zrt. which is one of the leading domestic distributor company of precision machinery, and technology users' data compared to control group of conventional farms selected in four different ways.

10. One of the important virtue of this study that the advantages of precision technologies were demonstrated using FDAN data, an EU wide data collection established fifty-years ago for the assessment of the Common Agricultural Policy (CAP). This is a significant element both from the point of view of policy and producers' decision making, because farms in FADN system be considered a sample which represents the market oriented farms.

11. Summarising the results of the research we can conlude that technology change results 7-17 per cent excess yield in case of winter wheat, 2-9 per cent for corn and 6-10 per cent for sunflower while it could not make such an estimate for rapeseed and winter barley according to the data was used in this study.

12. The increase of output was greater than the figures of yield change: 8-38 per cent value excess was experienced by winter wheat, 11-42 per cent by corn and 3-32 per cent by sunflower. Advantages of precision technology mainly depends on the seasonal weather, the soil conditions and the quality of management which explains that the range of output has wide intervals. Advantages of site-specific farming can be revealed during more adverse periods and/or areas, where only limited results can be achieved by conventional cultivation relative to yield potential.

13. Opposed to the expectations of more precise technology and variable-rate technology (VRT) our results show increased input use. The production cost - used as a proxy of input use - per hectare varied between -3 and +47 per cent in case of winter wheat, -5 and +30 per cent by corn and -8 and +26 per cent in case of sunflower compare to conventional technology.

14. In case of unit cost, additional inputs of precision technology have been slightly lower, decline in inputs is more likely to occur. This is not a surprise, because yield increase occur which result decrease in cost per unit output. We found -17 and +29 per cent difference in case of winter wheat, -13 and +22 per cent for corn and -17 and +20 per cent for sunflower compared to conventional cultivation.

15. If the growth of the gross output exceeds the growth of costs, the sectors' profit or income improves. According to our researches it happened unequivocally this way for winter wheat and sunflower. In case of winter wheat farmers reported 23-123 per cent additional income and in case of sunflower 28-52 per cent increase. Income growth for corn is less certain. We received report of 17 per cent decrease and increase by 105 per cent as well.

16. We developed sector level projections using existing data to demonstrate effects of adaption of precision farming. We studied possible changes of yield, gross output, production cost. We assumed the adaptation of precision technology is done by farms with similar characteristics to those already apply precision technology with positive outcome.

17. If the selected farms would apply precision technology with the same results, the total PA cultivated may reach 1.4 million hectares, which is 46.9 per cent of the total 2.9 million hectare (area 
of the relevant arable crops. The largest increase would occur in case of winter wheat, which means 59 per cent of the total wheat area, in case of corn it means 40 per cent and by sunflower 38 per cent. Winter barley and winter rape area which cultivated by precision technology may get 15-17 per cent of the total sown area of two sectors.

18. The macro effect than the additional 21 thousand PA farms could cause is 2.4-6 per cent growth of total yield (+342.7-+858.9 thousand tons) for all crops studied compared to the total domestic production of 14.3 million tons. Gross output would exceed the current value by HUF 32.0142.0 billion in case of the five arable crops which means in total HUF 826.2-936.2 billion.

19. Production cost would decrease by HUF 10.4 billion, from HUF 606.2 billion to HUF 595.9 billion, if the selected farms would introduce precision farming. The cost of seeds may decline by HUF 2.4 billion, the cost of fertilizers may increase by HUF 3.8 billion and the cost of pesticides may decrease by HUF 1.8 billion.

20. Sectors' total output may expand significantly in case of farms which switch to precision technology by HUF 15.2-88.5 billion so the total figure could rise from HUF 187.9 billion to HUF 203.1-276.4 billion.

21. Finally we also calculated the possible investment impact of such a change towards PA. Based on the assets value we formed three possible groups: 1 . the complete machinery change 2 . existing machinery requires specific updates with precision equipment, 3 . only supply of minor elements and precision software. For all three groups the investment costs would reach almost HUF 325 billion, largest part of these costs (about HUF 300 billion) would come from those require total machinery change.

22. We presented that if no complete machinery/asset change is needed the investment cost of PA - regardless of farm size - pays back. investment by farms which introduce the technology. However, the complete machinery change is not too realistic option, as these assets also used by other activities of the farm.

\subsection{Conclusions}

1. According to our survey significant investment costs was identified as a main barrier of the diffusion of precision technology. The lack of knowledge and the fear to learn new knowledge was also often mentioned as a barrier. Appropriate knowledges and skill of the use of precision technology were key factors among the criteria for the successful application of the technology. This was also in confirmed by the responses during the in-depth interviews. Considering the possible macroeconomic impacts of the technology, like output increase, better quality, higher yields and additional income, the agricultural policy should treat it as a priority.

2. Precision technology capable machinery is not enough to apply precision technology successfully. PA technology by far not homogeneous. Every operations have to be adapted to the local conditions (for example soil conditions and topography) and specific circumstances. Thoughtful skills are needed to reach the expected results, therefore it is very advisable to use external consultancy especially during the introduction phase. The targeted - positive - results can only be expected when technology is applied appropriately.

3. Compared to other EU countries with similar natural endowments input (especially fertilizer) use intensity in Hungary is typically low. Therefore, when PA as a more efficient technology is introduced we face with two parallel effects. First, due to better utilization, the input use rate usually increases compared to the baseline situation and often there is a changing of seed variety with higher yield potential. This also means that the input distributors are also interested in the diffusion of precision technology in arable farming. 
4. We came to the conclusion that there is not any universal rule or strategy for the introduction of PA technology that can guarantee success and lead to profit/income improvement. Due to lack of appropriate experience, the environmental and economical optimum is rarely known: What is the optimal input rate for different soils? Establishing the unified „rule" should be the topic of future research.

\subsection{Recommendations}

1. The core building block of precision farming is appropriate human capital or knowledge. In case of arable farming it is recommended to hire employees, who already has appropriate PA relevant qualification and able to apply precision technology. And even soon, this will be a must not only recommended! Current qualification level among arable farm employees are typically low. Altogether this foster the urgent need of change of agriculture education. In order to provide practical knowledge, it is advisable to train the teachers themselves by practitioners of the consultancy market. It is important to equip agricultural schools and universities with upto-date machineries and software's which able to apply precision farming and to operate these on a daily basis. This should be also supported to specialized consultants. It is recommended to continue to strengthen the role of dual training where precision farmers should be given a prominent role.

2. We recommend to establish a specific Fund to support fundamental and applied research topics which deal with precision farming. Applied research activities should involve key stakeholders (producers, consultants, machine manufacturer, IT companies) who gained experience of the use of PA technology in practice. This can guarantee that research sources help solving practical or real problems and the national agro-industrial, engineering and IT companies can grow and break into the digitalization of agricultural-related niche markets which will dramatically grow in the future.

3. Appropriate legal background should support smooth development of precision farming. In particular, farmers should get access to all data generated by precision farming and they will be able to get those from machine manufacturers and data recorders. Moreover, data - with proper licensing - should be used for public research purposes as well. The regulatory environment should provide realistic conditions to the use of modern technologies (e.g.: flight of drones) and soil sampling which can be considered as the core of precision technology. The soil sampling protocol should compulsory include geocoding of the samples. It is necessary to develop appropriate authorisation of existing and future public data (e.g.: perpetual, buyer or new tenants will be able to access to previous data of the board).

4. The increase of input use intensity and environmental sustainability is not a controversial, because with precision application (the right input to the right culture at the right time and location) crops can fully utilize nutrients, thus farmers will be able to product with less negative environmental impact. Taking this into account, related environmental barriers or limits could be even more strict for precision farms. In other words, those who carry out certified precision farming may can apply higher doses of agents because the exact input application causes more efficient uptake and less negative impact.

5. If the national or EU subsidy system - in form of subventions or repayable assistance, subsidized loans/interest - may provide funding for farmers to adapt precision technology elements, the of site-specific farming in Hungary may grow in a faster manner. Because precision farming tend to support environmental sustainability, farmers may be able to use PA as one optional element even through the Agro-Environmental Management Program of the Rural Development Program. 
6. We propose to repeat the similar surveys and analysis in the next few years, because the number of farms which introduce the technology continuously rising and the ,depth" of application of technology is also expected to improve. The current research results have been completed in the early start-up of the technology, so it can easily happen that a few years from now even more significant impacts can be found. 



\section{Kivonat}

\section{A precíziós szántóföldi növénytermesztés összehasonlító vizsgálata}

Kemény Gábor (szerk.), Lámfalusi Ibolya (szerk.) és Molnár András (szerk.)

A precíziós technológia alkalmazása a magyarországi szántóföldi növénytermesztésben jelenleg még kevésbé elterjedt, azonban a technológiát alkalmazó termelők számának növekedése az utóbbi két-három évben felgyorsult. A precíziós szántóföldi növénytermesztés összehasonlító vizsgálata" című tanulmányban a magyarországi tesztüzemi hálózat szántóföldi növénytermesztő üzemeinek bevonásával kérdőíves felmérés és mélyinterjúk keretében megvizsgáltuk a precíziós, valamint talajkímélő gazdálkodás magyarországi elterjedtségét, illetve felmértük az alkalmazott technológia színvonalát. A felmérés eredményei és a tesztüzemi rendszerben rendelkezésre álló adatok felhasználásával összehasonlító vizsgálatokat végeztünk a precíziós gazdálkodás előnyeinek/hátrányainak kimutatására a hozamváltozás, inputanyag-felhasználás, termelési érték, önköltség és jövedelem vonatkozásában öt növénykultúra esetében. Az eredmények a hozamok, a termelési érték valamint az ágazati eredmény növekedését, illetve az önköltség csökkenését támasztották alá. A várakozásokkal ellentétben vizsgálataink az inputköltségek tekintetében is növekedést jeleztek, amely azzal magyarázható hogy Magyarországon az inputfelhasználás szintje jellemzően alacsony, így modern mủvelési módra való áttéréssel a kívánatos hozamok elérése érdekében az inputfelhasználás intenzitását növelni szükséges. A rendelkezésünkre álló adatok birtokában ágazati szinten becsléseket végeztünk a precíziós tevékenységre való áttérés makroszintü hatásaira. Majd a becslés zárásaként azt is megvizsgáltuk, hogy hogyan alakulna a beruházási költség a technológiát váltó üzemeknél. 


\section{Abstract}

\section{Comparative study of precision arable crop production}

KEMÉNY, Gábor (eds.), LÁMFALUSI, Ibolya (eds.) and MOLNÁR, András (eds.)

The use of precision technology among arable crop farms is still less widespread in Hungary but increase of the number of producers using the technology has been accelerated in the last two-three years. In the study entitled „Comparative study of precision arable crop production” the incidence of precision and no tillage farming in Hungary and the level of used technology was examined among arable crop farms of the Hungarian Farm Accountancy Data Network system by a questionnaire survey and in-depth interviews. Using the results of the survey and the data available in the FADN system, comparative assessment was completed to explore the benefits / disadvantages of precision farming regarding attainable yield, input use, output, unit cost and income for the five most dominant arable crops in Hungary. The results confirmed that application of precision technology leads increasing yields, output, per hectare profit and unit costs. In contrast to expectations, our investigations showed also increase in input costs, which can be explained by the low initial level of input use, quite common among arable farms in Hungary. The change towards to modern technology means that intensity of input use needs to be increase in order to achieve optimaleconomic performance, that is attainable with higher yields. With the available data, we carried out sector-level estimates of the macroeconomic effects, assuming farms with similar structural characteristics introduce precision farming. Finally, the cost-benefit of investment needed for the introduction of precision technology was assessed. 


\section{Mellékletek}

\subsection{Mellékletek jegyzéke}

1. melléklet: A talajkímélő művelés elterjedését gátló tényezők 144

2. melléklet: A talajkímélő művelés elterjedését elősegítő tényezők 144

3. melléklet:Az átlagos hozam alakulása a precíziós mintaüzemeknél a napraforgó esetében 145

4. melléklet: Az átlagos hozam alakulása a mintaüzemeknél a repce esetében 145

5. melléklet: Az átlagos hozam alakulása a mintaüzemeknél a cukorrépa esetében 146

6. melléklet: Technológiai szintek lehatárolása. 147

7. melléklet: Shapiro-Wilk-teszt eredménye. 148

8. melléklet: Az ágazati eredmény alakulása a precíziós tevékenység bevezetése előtti és az alkalmazást követő 3 év átlagában

9. melléklet: A termelési érték és a termelési költség hányadosának alakulása a precíziós technológia alkalmazása előtti és az azt követő 3 év átlagában

10. melléklet: Az egyes növények termelési költség- és területi korlátai

11. melléklet: A precíziós gazdálkodás és a hagyományos termelés különbségei a hagyományos gazdálkodást jellemző értékek százalékában kifejezve.

12. melléklet: Az üzemek számának és területének változása a precíziós gazdálkodás hatására... 151

13. melléklet: A termésmennyiség változása a precíziós gazdálkodás hatására ............................ 152

14. melléklet: A termelési érték változása a precíziós gazdálkodás hatására................................ 152

15. melléklet: Az ágazati eredmény változása a precíziós gazdálkodás hatására 153

16. melléklet: A termelési költség változása a precíziós gazdálkodás hatására 153

17. melléklet: A vetőmagköltség változása a precíziós gazdálkodás hatására 154

18. melléklet: A mütrágyaköltség változása a precíziós gazdálkodás hatására. 154

19. melléklet: A növényvédőszer-költség változása a precíziós gazdálkodás hatására 155

20. melléklet: Komplett gépparkcsere eszközei és költségei 2000 hektárra 155

21. melléklet: Komplett gépparkcsere eszközei és költségei 500 hektárra 156

22. melléklet: Precíziós elemekkel történő felszerelés eszközei és költségei 2000 hektárra 156

23. melléklet: Precíziós elemekkel történő felszerelés eszközei és költségei 500 hektárra 157

24. melléklet: Szoftveres felszereltség elemei és költségei 2000 hektárra 157

25. melléklet: Szoftveres felszereltség elemei és költségei 500 hektárra 


\section{1. melléklet: A talajkímélő múvelés elterjedését gátló tényezők}

Nem vehetők igénybe a hiányzó technológiai elemek szolgáltatáskén Egyéb Elérhető szaktanácsadás hiánya

Bizalmatlanság az új technológiákkal szemben Megfelelö finanszírozás hiánya Alkalmazáshoz szükséges szaktudás hiánya Új technológia bevezetéséhez szükséges idő Nem illeszkedik a gazdaság méretéhez Üzemeltetési tapasztalat hiánya Beruházás többletköltsége
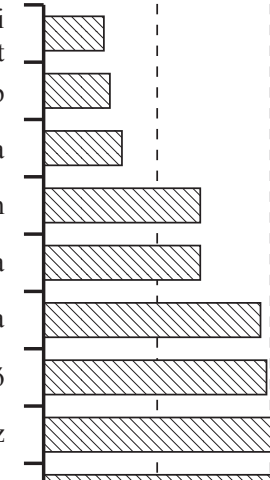

$$
\text { Beruházás többletköltsége }
$$

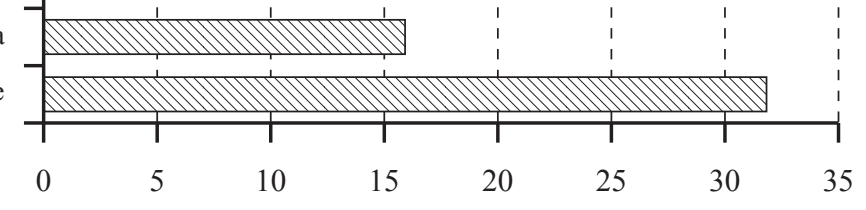

százalék

Forrás: Kérdőíves felmérés alapján készült az AKI Horizontális Elemzési Osztályán

\section{2. melléklet: A talajkímélő múvelés elterjedését elősegítő tényezők}

Adatrögzítésre alkalmas mobilapplikáció megléte

Egyéb

Feltételek mellett bekerülne az AKG-támogatásba

Közösen használt eszközök támogatása (pl. gépkör)

Bekerülne a zöldítési támogatásba

(bizonyos kötelezettség automatikus teljesítése)

Beruházási támogatás a Vidékfejlesztési Programban

Kompatibilitás a technológiák között

Több és/vagy részletesebb információ

Magasabb felvásárlási ár (pl. előnyöket biztosító tanúsítvány)

Bekerülne az egységes területalapú (SAPS) támogatásba (éves kifizetés)

Magasabb jövedelmezőség

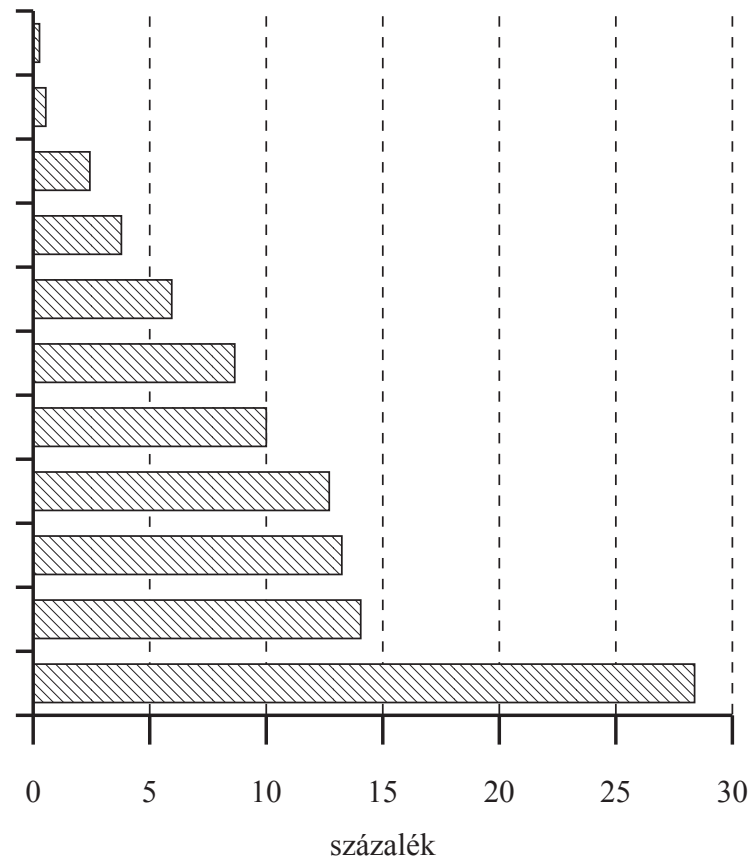

Forrás: Kérdőives felmérés alapján készült az AKI Horizontális Elemzési Osztályán 
3. melléklet: Az átlagos hozam alakulása a precíziós mintaüzemeknél a napraforgó esetében

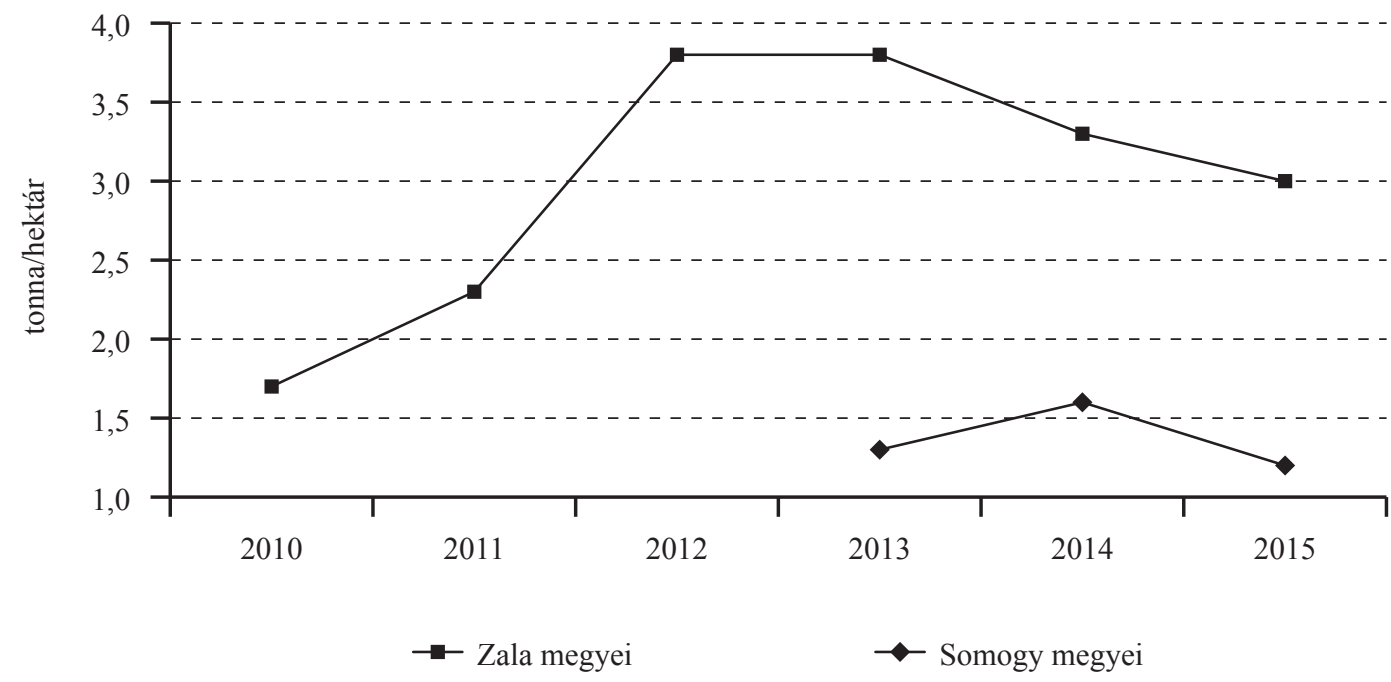

Forrás: AKI Horizontális Elemzési Osztály

4. melléklet: Az átlagos hozam alakulása a mintaüzemeknél a repce esetében

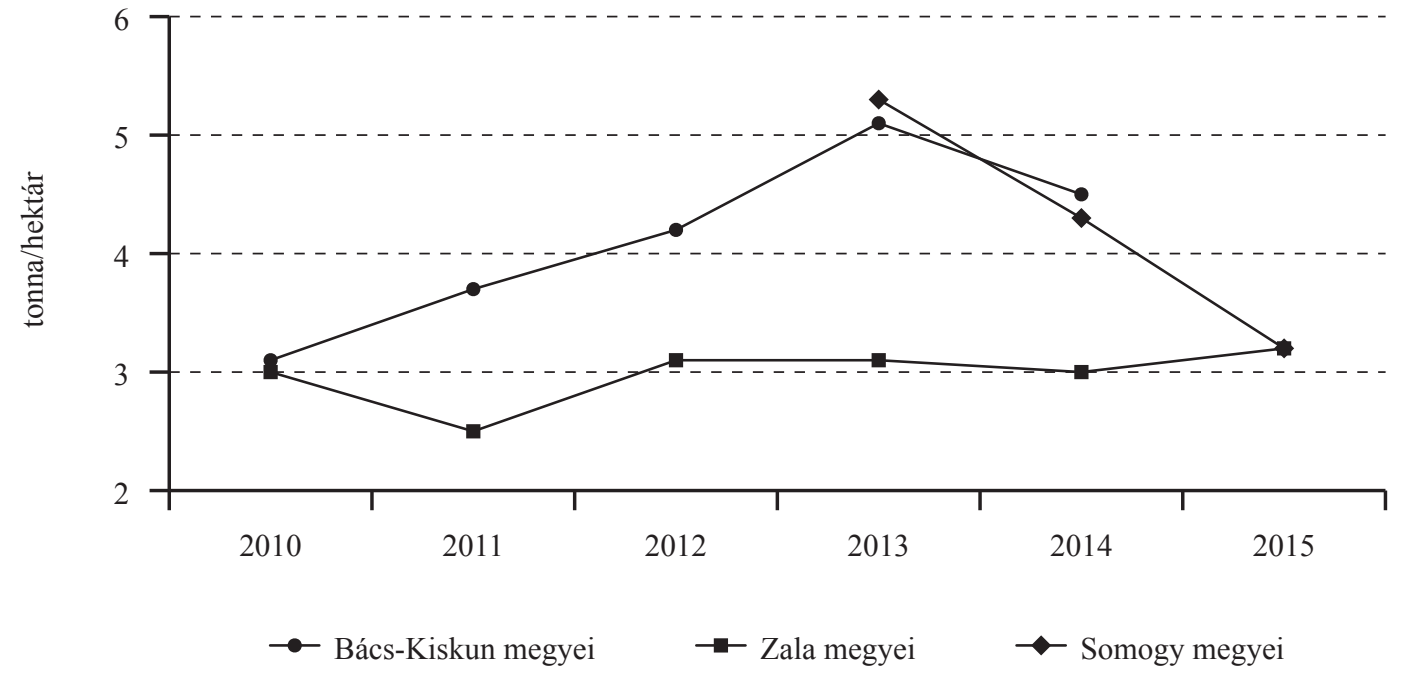

Forrás: AKI Horizontális Elemzési Osztály 
5. melléklet: Az átlagos hozam alakulása a mintaüzemeknél a cukorrépa esetében

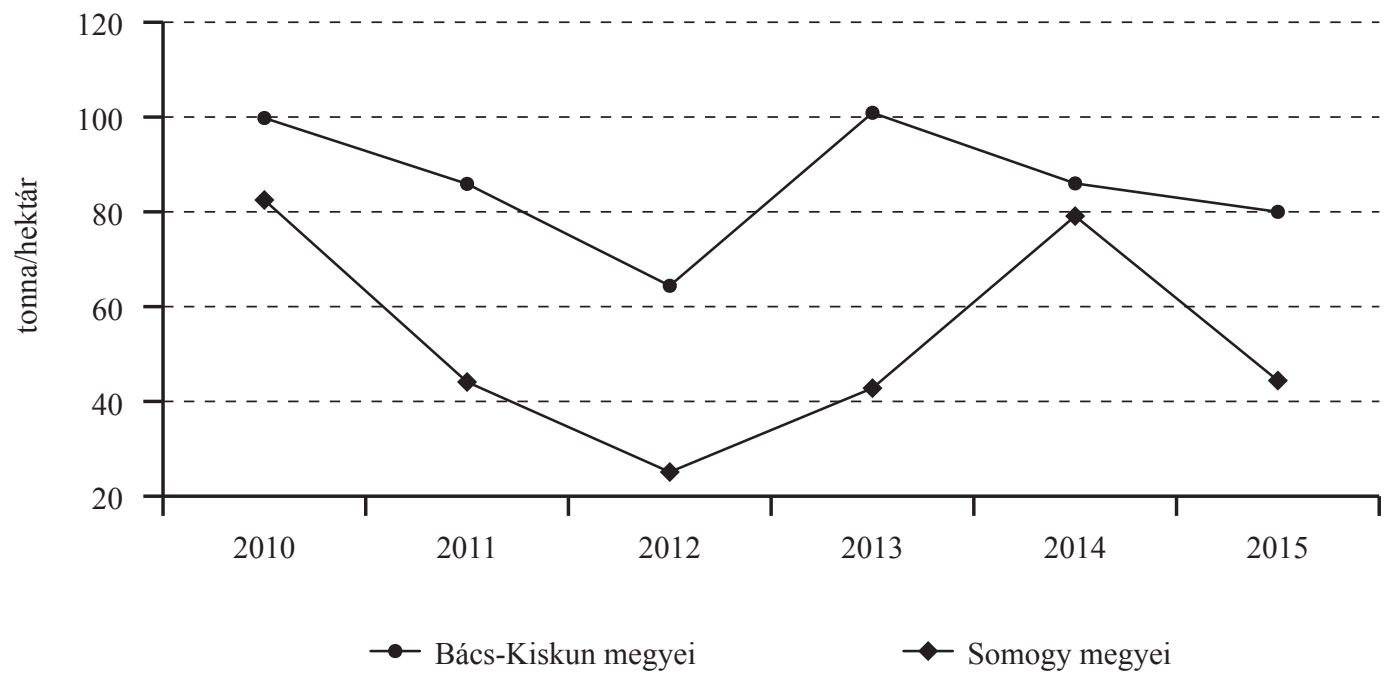

Forrás: AKI Horizontális Elemzési Osztály 


\section{6. melléklet: Technológiai szintek lehatárolása}

Ahogy az már az anyag és módszertan leírásánál említésre került, a számítási eredmények 4 lépést tettek szükségessé. Elsődlegesen a precíziós gazdaságok különböző technológiai szintekbe kerültek besorolásra, melyek a következők: csak sormüvelést végző üzemek (I. kategória), csak kombinált tevékenységet folytató gazdaságok (II. kategória) - például alapmüveléssel egybekötött tápanyagkijuttatás -, változó tőszámú vetésre és menet közben módosítható müvelésmélységre képesek (III. kategória), menedzsmentzónánként differenciált kijuttatást alkalmazók (IV. kategória), illetve egyéb technológiai elemben precíziós technikát folytató vállalkozások (V. kategória). Az egyéb technológia esetében a válaszadók nem jelölték meg, hogy mit alkalmaznak, ezáltal a csoport adatai további elemzésekre nem alkalmasak.

A búzatermesztésben a 32 üzem csaknem fele (14 gazdaság) alakít ki menedzsmentzónákat és azok igényeinek megfelelő mennyiségben, helyspecifikusan juttatja ki a növényvédő szert és/vagy a tápanyagot. Közülük 4 precíziós gazdaság a tőszám és a müvelésmélység változtatására is képes a mủvelés során. A termesztők közül mindössze 2 gazdaság kombinálja az agrotechnikai elemeket, illetve 11 gazdaság kizárólag sormüvelést alkalmaz a termesztési gyakorlat során. A fennmaradó üzemek a felsorolásban nem szereplő technológiát alkalmaztak.

A kukorica esetében a 32 gazdaság 43,8 százaléka (14 üzem) foglalkozik magas színvonalon a precíziós termesztéstechnológia alkalmazásával, melyből szintén négyen tartoznak a III., hárman pedig a IV. kategóriába. A precíziós gazdaságok további egyharmada csakis sormüvelést végez az egyes agrotechnikai elemekben.

A 27 napraforgót termesztő gazdaság egyharmada műveli a kultúrnövényét a precíziós technológia legmagasabb szintjén. Ebből mindössze 2 gazdaság változtatja vetés közben a tőszámot és/vagy a talaj mủvelésének mélységét és 3 üzem végzi összevontan a növénytermesztés bizonyos mủveleteit. A napraforgó termesztésében a legjellemzőbb a sormüvelés volt, a precíziós üzemek közel fele alkalmazta ezt a technológiát.

Öszi káposztarepcét 16 gazdaság termesztett a 2015. évben, melyből 8 üzem tartozott a IV. kategóriába, 3 gazdaság pedig a III. kategóriába került besorolásra. A müvelési elemek kombinációját mindössze 1 üzem választotta, ezzel szemben az összes precíziós repcetermesztő 37,5 százaléka sormüvelést végzett. 
7. melléklet: Shapiro-Wilk-teszt eredménye

\begin{tabular}{|c|c|c|c|c|c|}
\hline \multirow{2}{*}{ Kategória } & \multirow{2}{*}{ Növény } & & \multicolumn{3}{|c|}{ Shapiro-Wilk } \\
\hline & & & statisztika & df & szignifikancia \\
\hline \multirow{15}{*}{ Nem precíziós gazdaság } & \multirow{5}{*}{ Búza } & Hozamátlag & 0,981 & 33 & 0,805 \\
\hline & & Termelési érték & 0,973 & 33 & 0,574 \\
\hline & & Termelési költség & 0,951 & 33 & 0,140 \\
\hline & & Ágazati eredmény & 0,972 & 33 & 0,549 \\
\hline & & Önköltség & 0,979 & 33 & 0,742 \\
\hline & \multirow{5}{*}{ Kukorica } & Hozamátlag & 0,935 & 24 & 0,124 \\
\hline & & Termelési érték & 0,960 & 24 & 0,438 \\
\hline & & Termelési költség & 0,952 & 24 & 0,302 \\
\hline & & Ágazati eredmény & 0,947 & 24 & 0,231 \\
\hline & & Önköltség & 0,957 & 24 & 0,380 \\
\hline & \multirow{5}{*}{ Napraforgó } & Hozamátlag & 0,945 & 23 & 0,224 \\
\hline & & Termelési érték & 0,968 & 23 & 0,650 \\
\hline & & Termelési költség & 0,917 & 23 & 0,057 \\
\hline & & Ágazati eredmény & 0,922 & 23 & 0,074 \\
\hline & & Önköltség & 0,883 & 23 & 0,012 \\
\hline \multirow{15}{*}{ Precíziós gazdaság } & \multirow{5}{*}{ Búza } & Hozamátlag & 0,980 & 36 & 0,749 \\
\hline & & Termelési érték & 0,956 & 36 & 0,165 \\
\hline & & Termelési költség & 0,969 & 36 & 0,393 \\
\hline & & Ágazati eredmény & 0,970 & 36 & 0,416 \\
\hline & & Önköltség & 0,957 & 36 & 0,170 \\
\hline & \multirow{5}{*}{ Kukorica } & Hozamátlag & 0,973 & 24 & 0,729 \\
\hline & & Termelési érték & 0,974 & 24 & 0,774 \\
\hline & & Termelési költség & 0,934 & 24 & 0,119 \\
\hline & & Ágazati eredmény & 0,941 & 24 & 0,168 \\
\hline & & Önköltség & 0,923 & 24 & 0,067 \\
\hline & \multirow{5}{*}{ Napraforgó } & Hozamátlag & 0,927 & 23 & 0,092 \\
\hline & & Termelési érték & 0,937 & 23 & 0,158 \\
\hline & & Termelési költség & 0,933 & 23 & 0,130 \\
\hline & & Ágazati eredmény & 0,949 & 23 & 0,276 \\
\hline & & Önköltség & 0,985 & 23 & 0,968 \\
\hline
\end{tabular}

Forrás: Ágazati költség- és jövedelemelszámolási adatok alapján SPSS program segítségével készült az AKI Horizontális Elemzési Osztályán 
8. melléklet: Az ágazati eredmény alakulása a precíziós tevékenység bevezetése előtti és az alkalmazást követő 3 év átlagában

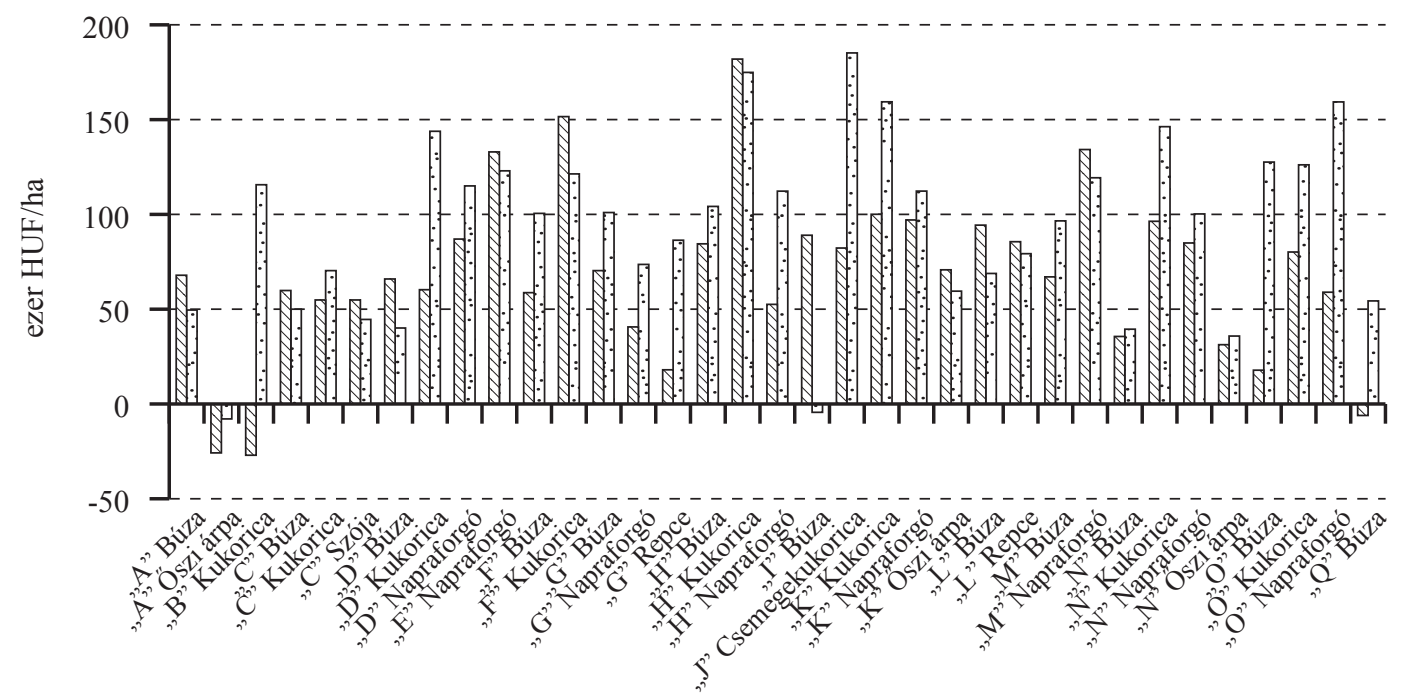

Precíziós gazdálkodás bevezetése előtt $\square$ Precíziós gazdálkodás bevezetése után

Forrás: Ágazati költség- és jövedelemelszámolási adatok alapján készült az AKI Horizontális Elemzési Osztályán

9. melléklet: A termelési érték és a termelési költség hányadosának alakulása a precíziós technológia alkalmazása előtti és az azt követő 3 év átlagában

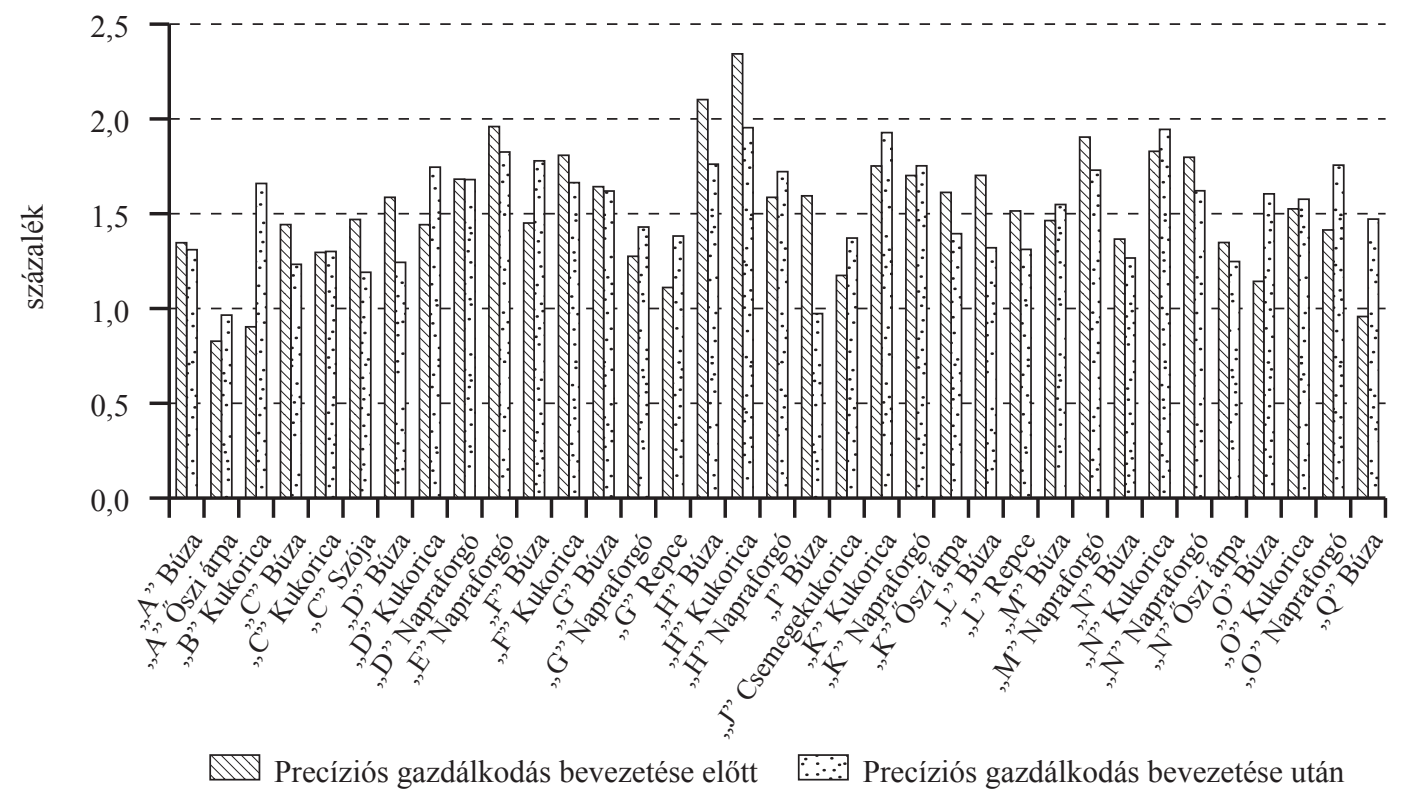

Forrás: Ágazati költség- és jövedelemelszámolási adatok alapján készült az AKI Horizontális Elemzési Osztályán 


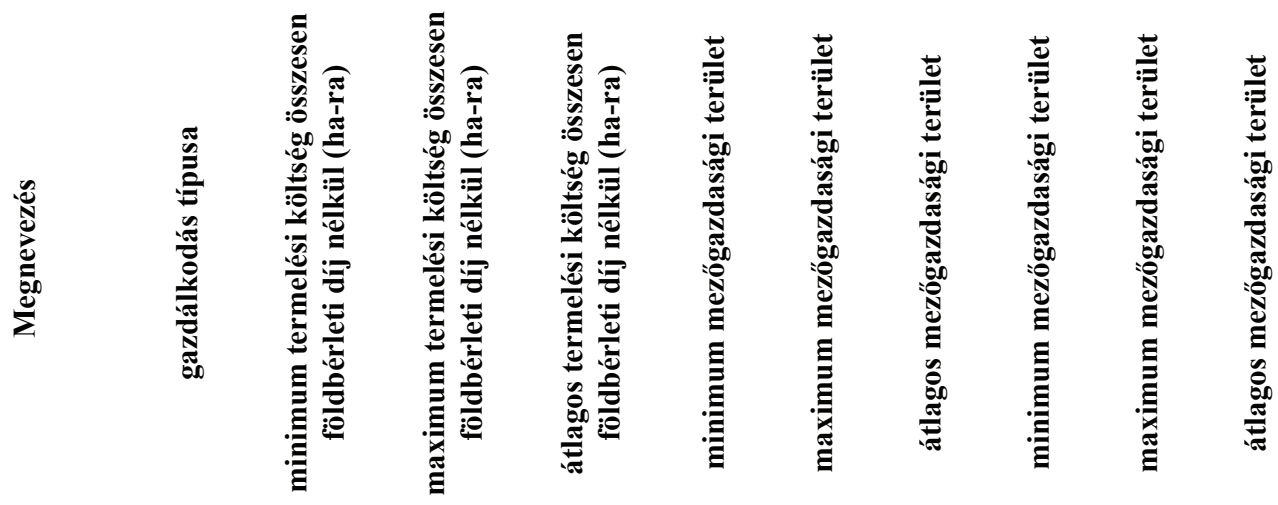

\begin{tabular}{|c|c|c|c|c|c|c|c|c|c|c|}
\hline & & & HUF & & & & h & & & \\
\hline \multirow{2}{*}{ Búza } & egyéni & 107023 & 285591 & 177304 & 65 & 450 & 207 & 65 & 450 & 207 \\
\hline & társas & 157687 & 254670 & 200843 & 488 & 2300 & 1279 & 488 & 2300 & 1279 \\
\hline \multirow{2}{*}{ Kukorica } & egyéni & 143424 & 282026 & 197295 & 65 & 583 & 227 & 65 & 583 & 227 \\
\hline & társas & 244759 & 340006 & 284011 & 488 & 514 & 497 & 488 & 514 & 497 \\
\hline \multirow{2}{*}{ Napraforgó } & egyéni & 127416 & 228357 & 166249 & 65 & 583 & 262 & 65 & 583 & 262 \\
\hline & társas & 153519 & 213062 & 175190 & 2300 & 2300 & 2300 & 488 & 2300 & 2300 \\
\hline $\begin{array}{l}\text { Öszi } \\
\text { káposztarepce }\end{array}$ & társas & 251483 & 255246 & 253140 & 958 & 1091 & 1040 & 65 & 583 & 284 \\
\hline Öszi árpa & egyéni & 130193 & 202602 & 158254 & 121 & 583 & 284 & 488 & 1091 & 1040 \\
\hline
\end{tabular}

Megjegyzés: Szín a módosítást jelöli az eredetihez képest.

Forrás: Az AKI Horizontális Elemzési Osztályán készült számítások 
11. melléklet: A precíziós gazdálkodás és a hagyományos termelés különbségei a hagyományos gazdálkodást jellemző értékek százalékában kifejezve

százalék

\begin{tabular}{|c|c|c|c|c|c|c|c|c|c|c|c|c|c|c|c|c|c|c|c|c|c|}
\hline \multirow[b]{2}{*}{ Megnevezés } & \multicolumn{3}{|c|}{ Hozam } & \multicolumn{3}{|c|}{$\begin{array}{c}\text { Ágazati } \\
\text { eredmény }\end{array}$} & \multicolumn{3}{|c|}{$\begin{array}{c}\text { Termelési } \\
\text { érték }\end{array}$} & \multicolumn{3}{|c|}{$\begin{array}{c}\text { Termelési } \\
\text { költség }\end{array}$} & \multicolumn{3}{|c|}{$\begin{array}{l}\text { Vetőmag- } \\
\text { költség }\end{array}$} & \multicolumn{3}{|c|}{$\begin{array}{c}\text { Növényvédő- } \\
\text { szer-költség }\end{array}$} & \multicolumn{3}{|c|}{$\begin{array}{l}\text { Múttrágya- } \\
\text { költség }\end{array}$} \\
\hline & 音 & $\stackrel{\Xi}{\Xi}$ & 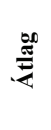 & $\stackrel{\Xi}{.}$ & 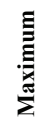 & $\frac{\sqrt[5]{5}}{\dot{E}}$ & 音 & 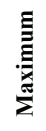 & $\frac{\sqrt[5]{\tilde{J}}}{\frac{E}{4}}$ & $\stackrel{\Xi}{E}$ & 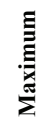 & 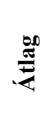 & 声 & 䍜 & $\frac{500}{\sqrt[E]{E}}$ & 声 & $\stackrel{\Xi}{\Xi}$ & 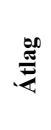 & 㤩 & 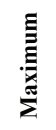 & $\frac{20}{\sqrt{\frac{\pi}{2}}}$ \\
\hline Búza & 107 & 117 & 114 & 123 & 233 & 161 & 108 & 138 & 117 & 97 & 147 & 113 & 74 & 147 & 96 & 94 & 148 & 114 & 126 & 146 & 135 \\
\hline Kukorica & 102 & 109 & 105 & 83 & 205 & 148 & 111 & 142 & 120 & 95 & 130 & 112 & 102 & 147 & 117 & 79 & 156 & 107 & 86 & 149 & 118 \\
\hline Napraforgó & 106 & 110 & 108 & 128 & 152 & 135 & 103 & 132 & 113 & 92 & 126 & 105 & 100 & 124 & 109 & 99 & 142 & 119 & 91 & 157 & 115 \\
\hline $\begin{array}{l}\text { Őszi } \\
\text { káposztarepce }\end{array}$ & 111 & 111 & 111 & 140 & 140 & 140 & 124 & 124 & 124 & 119 & 119 & 119 & 97 & 97 & 97 & 137 & 137 & 137 & 131 & 131 & 131 \\
\hline Öszi árpa & 105 & 105 & 105 & 130 & 130 & 130 & 113 & 113 & 113 & 109 & 109 & 109 & 114 & 114 & 114 & 108 & 108 & 108 & 123 & 123 & 123 \\
\hline
\end{tabular}

Forrás: Az AKI Horizontális Elemzési Osztályán készült számítások

12. melléklet: Az üzemek számának és területének változása a precíziós gazdálkodás hatására

\begin{tabular}{lcccc}
\hline Megnevezés & $\begin{array}{c}\text { Üzemek száma } \\
\text { összesen, } \\
\text { darab }\end{array}$ & $\begin{array}{c}\text { Precíziós gazdál- } \\
\text { kodásra áttérő } \\
\text { üzemek száma, } \\
\text { darab }\end{array}$ & $\begin{array}{c}\text { Összes üzem } \\
\text { területe, } \\
\text { ezer hektár }\end{array}$ & $\begin{array}{c}\text { Precíziós gazdál- } \\
\text { kodásra áttérö } \\
\text { üzemek precíziós } \\
\text { területe, } \\
\text { ezer hektár }\end{array}$ \\
\hline Búza & 35372 & 7129 & 937,5 & 553,1 \\
\hline Kukorica & 50251 & 6601 & 933,3 & 371,8 \\
\hline Napraforgó & 22402 & 4574 & 585,3 & 221,2 \\
\hline Öszi árpa & 13210 & 1150 & 203,5 & 34,0 \\
\hline Öszi káposztarepce & 7157 & 210 & 241,0 & 37,3 \\
\hline
\end{tabular}

Megjegyzés: Az üzemek száma összesen a magyarországi összes üzemszámot jelöli az adott kultúra vonatkozásában.

Forrás: Az AKI Horizontális Elemzési Osztályán készült számítások 
13. melléklet: A termésmennyiség változása a precíziós gazdálkodás hatására
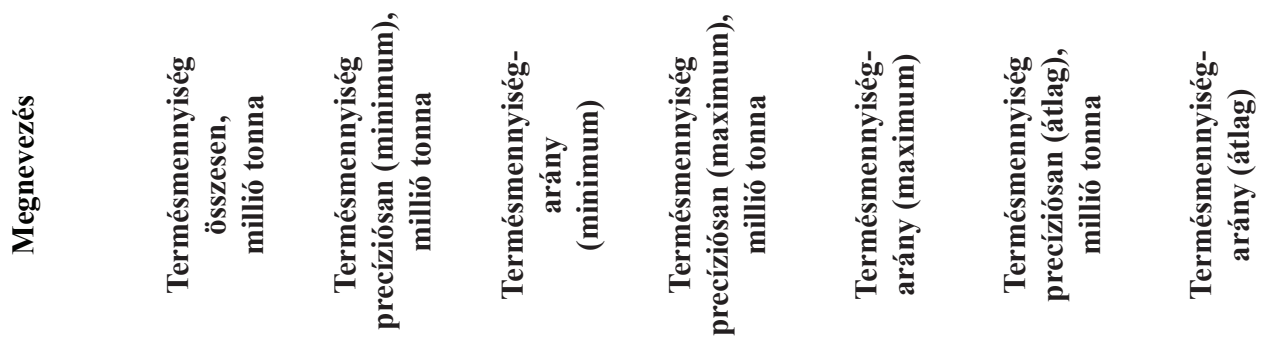

\begin{tabular}{llllllll}
\hline Búza & 5,1 & 5,3 & 1,04 & 5,6 & 1,10 & 5,5 & 1,08 \\
\hline Kukorica & 6,0 & 6,0 & 1,01 & 6,2 & 1,04 & 6,1 & 1,02 \\
\hline Napraforgó & 1,5 & 1,6 & 1,02 & 1,6 & 1,04 & 1,6 & 1,03 \\
\hline Őszi árpa & 1,0 & 1,0 & 1,01 & 1,0 & 1,01 & 1,0 & 1,01 \\
\hline Őszi & 0,7 & 0,7 & 1,02 & 0,7 & 1,02 & 0,7 & 1,02 \\
káposztarepce & 0,7 &
\end{tabular}

Megjegyzés: A termésmennyiség összesen az országos termésmennyiséget jelöli.

Forrás: Az AKI Horizontális Elemzési Osztályán készült számítások

14. melléklet: A termelési érték változása a precíziós gazdálkodás hatására

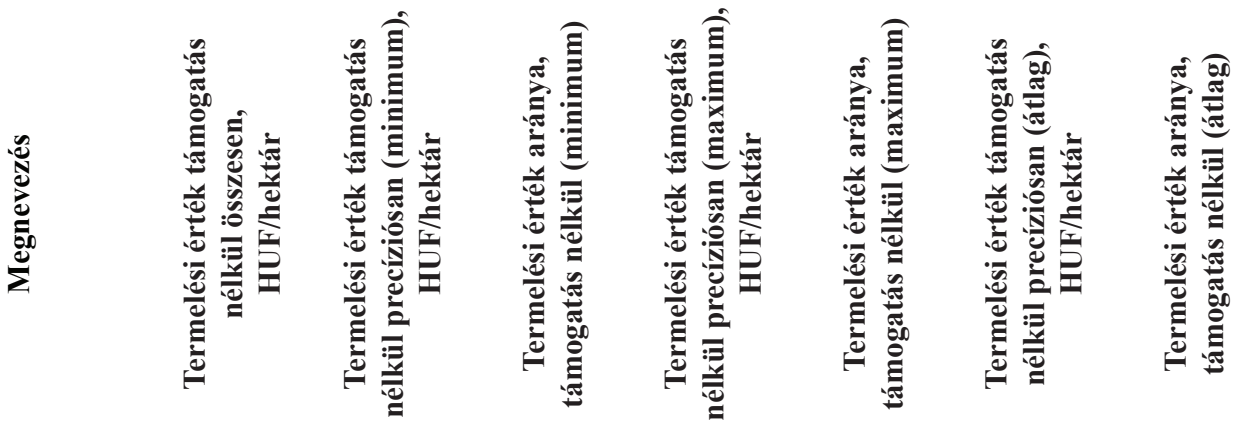

\begin{tabular}{lrrrrrrr}
\hline Búza & 247505 & 259486 & 1,05 & 304413 & 1,23 & 272964 & 1,10 \\
\hline Kukorica & 256176 & 268242 & 1,05 & 302248 & 1,18 & 278115 & 1,09 \\
\hline Napraforgó & 170822 & 172761 & 1,01 & 191506 & 1,12 & 179225 & 1,05 \\
\hline Öszi árpa & 44045 & 44992 & 1,02 & 44992 & 1,02 & 44992 & 1,02 \\
\hline Öszi káposztarepce & 75591 & 78477 & 1,04 & 78477 & 1,04 & 78477 & 1,04 \\
\hline
\end{tabular}

Megjegyzés: A termelési érték támogatás nélkül összesen az országos termelési értéket jelöli az érintett növénykultúrák vonatkozásában.

Forrás: Az AKI Horizontális Elemzési Osztályán készült számítások 

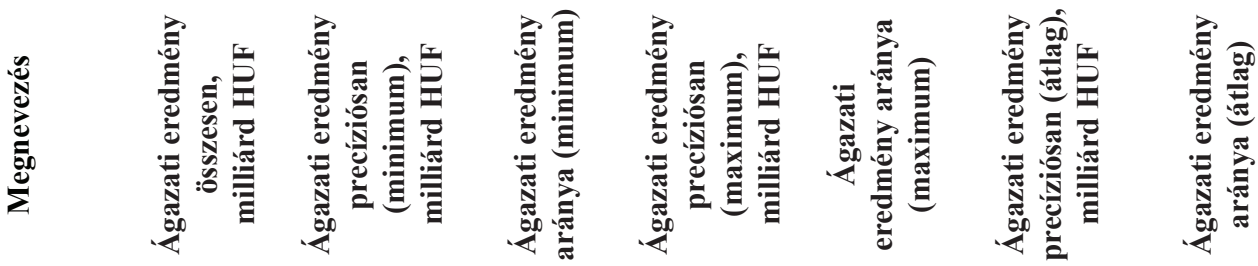

\begin{tabular}{lrrrrrrr}
\hline Búza & 66,8 & 76,1 & 1,14 & 120,3 & 1,80 & 91,3 & 1,37 \\
\hline Kukorica & 40,5 & 37,4 & 0,92 & 21,3 & 0,53 & 49,3 & 1,22 \\
\hline Napraforgó & 52,7 & 58,5 & 1,11 & 63,4 & 1,20 & 59,9 & 1,14 \\
\hline Öszi árpa & 8,4 & 8,9 & 1,05 & 8,9 & 1,05 & 8,9 & 1,05 \\
\hline Öszi & 19,4 & 20,1 & 1,04 & 20,1 & 1,04 & 20,1 & 1,04 \\
káposztarepce & 1904
\end{tabular}

Megjegyzés: Az ágazati eredmény összesen az országos ágazati eredményt jelöli az egyes növénykultúrák vonatkozásában.

Forrás: Az AKI Horizontális Elemzési Osztályán készült számítások

16. melléklet: A termelési költség változása a precíziós gazdálkodás hatására
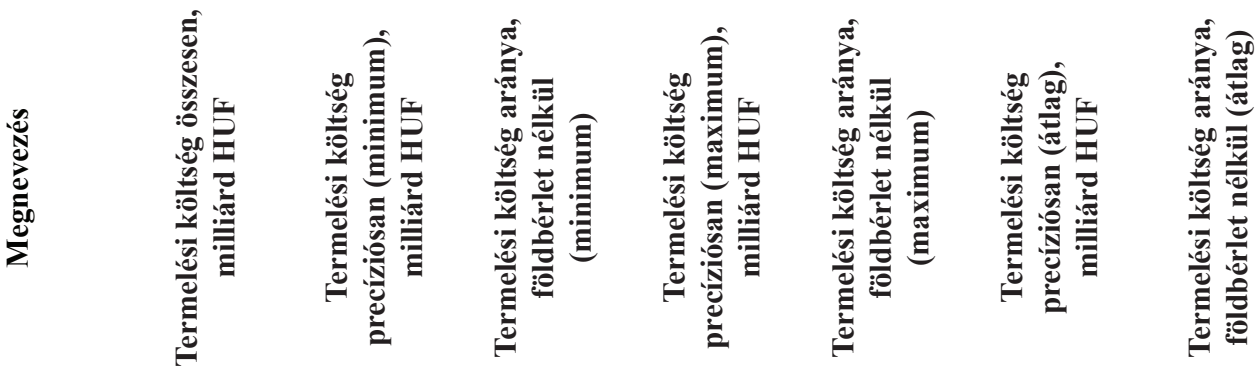

\begin{tabular}{lrrrrrrr}
\hline Búza & 180,7 & 177,4 & 0,98 & 232,2 & 1,28 & 194,9 & 1,08 \\
\hline Kukorica & 215,6 & 211,1 & 0,98 & 243,1 & 1,13 & 226,6 & 1,05 \\
\hline Napraforgó & 118,1 & 114,6 & 0,97 & 129,6 & 1,10 & 120,3 & 1,02 \\
\hline Öszi árpa & 35,6 & 36,1 & 1,01 & 36,1 & 1,01 & 36,1 & 1,01 \\
\hline $\begin{array}{l}\text { Öszi } \\
\text { káposztarepce }\end{array}$ & 56,2 & 58,1 & 1,03 & 58,1 & 1,03 & 58,1 & 1,03 \\
\hline
\end{tabular}

Megjegyzés: A termelési költség összesen az egyes ágazatok országos szintü termelési költségét jelenti.

Forrás: Az AKI Horizontális Elemzési Osztályán készült számítások 
17. melléklet: A vetőmagköltség változása a precíziós gazdálkodás hatására

\begin{tabular}{|c|c|c|c|c|c|c|c|}
\hline 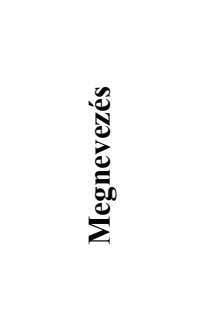 & 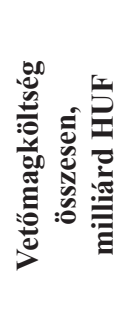 & 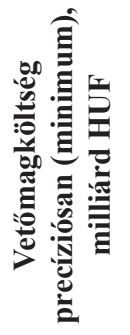 & 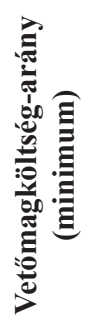 & 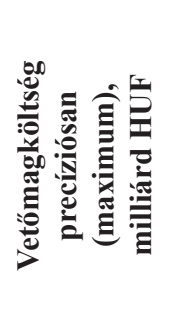 & 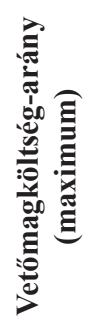 & 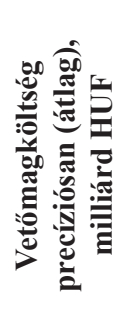 & 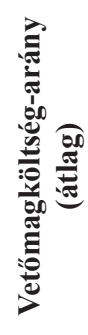 \\
\hline Búza & 17,935 & 15,194 & 0,85 & 22,89 & 1,28 & 17,51 & 0,98 \\
\hline Kukorica & 32,360 & 32,629 & 1,01 & 38,70 & 1,20 & 34,65 & 1,07 \\
\hline Napraforgó & 13,333 & 18,270 & 1,37 & 14,52 & 1,09 & 13,78 & 1,03 \\
\hline Öszi árpa & 3,631 & 3,711 & 1,02 & 3,71 & 1,02 & 3,71 & 1,02 \\
\hline $\begin{array}{l}\text { Öszi } \\
\text { káposztarepce }\end{array}$ & 4,458 & 4,435 & 0,99 & 4,44 & 0,99 & 4,44 & 0,99 \\
\hline
\end{tabular}

Megjegyzés: A vetőmagköltség összesen az országos vetömagköltséget jelenti az egyes növénykultúrák vonatkozásában. Forrás: Az AKI Horizontális Elemzési Osztályán készült számítások

18. melléklet: A mütrágyaköltség változása a precíziós gazdálkodás hatására

\begin{tabular}{|c|c|c|c|c|c|c|c|}
\hline 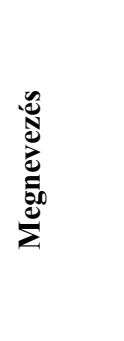 & 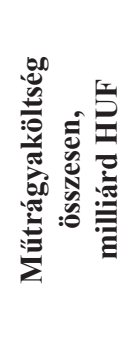 & 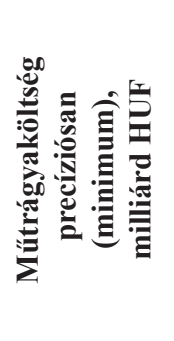 & 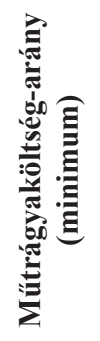 & 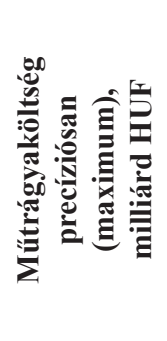 & 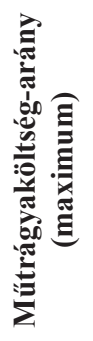 & 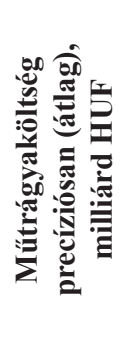 & 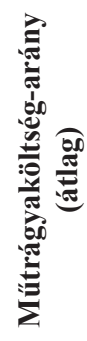 \\
\hline & 40,9 & 47,3 & 1,15 & 52,1 & 1,27 & 49,5 & 1,21 \\
\hline rica & 36,2 & 34,1 & 0,94 & 43,7 & 1,21 & 39,0 & 1,08 \\
\hline aforgó & 17,5 & 16,9 & 0,97 & 21,0 & 1,20 & 18,4 & 1,05 \\
\hline árpa & 7,5 & 7,8 & 1,04 & 7,8 & 1,04 & 7,8 & 1,04 \\
\hline epce & 13,7 & 14,4 & 1,05 & 14,4 & 1,05 & 14,4 & 1,05 \\
\hline
\end{tabular}

Megjegyzés: A műtrágyaköltség összesen az országos mütrágyaköltséget jelenti.

Forrás: Az AKI Horizontális Elemzési Osztályán készült számítások 
19. melléklet: A növényvédőszer-költség változása a precíziós gazdálkodás hatására

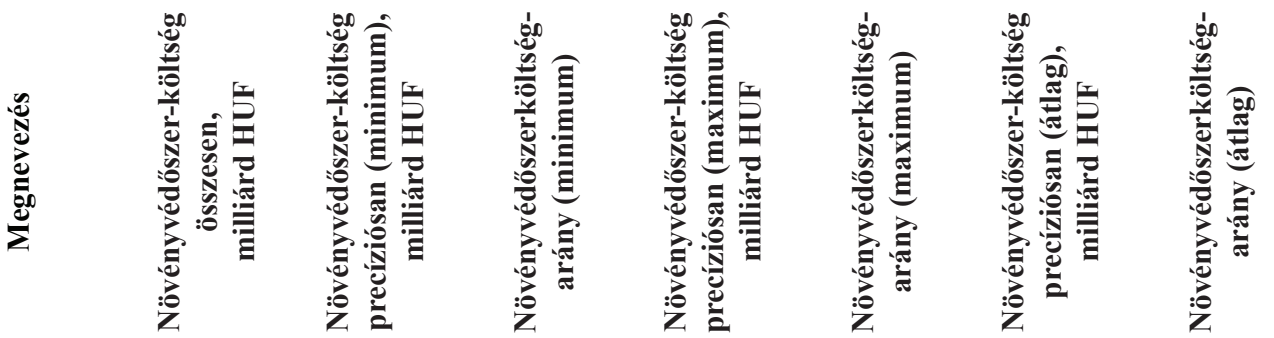

\begin{tabular}{lrrrrrrr}
\hline Búza & 21,1 & 20,3 & 0,96 & 27,5 & 1,30 & 23,0 & 1,09 \\
\hline Kukorica & 22,4 & 20,5 & 0,91 & 27,6 & 1,23 & 23,1 & 1,03 \\
\hline Napraforgó & 18,8 & 18,8 & 1,00 & 21,6 & 1,15 & 20,1 & 1,07 \\
\hline Öszi árpa & 3,8 & 3,8 & 1,01 & 3,8 & 1,01 & 3,8 & 1,01 \\
\hline $\begin{array}{l}\text { Öszi } \\
\text { káposztarepce }\end{array}$ & 10,1 & 10,9 & 1,07 & 10,9 & 1,07 & 10,9 & 1,07 \\
\hline
\end{tabular}

Megjegyzés: A növényvédőszer-költség összesen az országos növényvédőszer-felhasználást jelenti.

Forrás: Az AKI Horizontális Elemzési Osztályán készült számítások

20. melléklet: Komplett gépparkcsere eszközei és költségei 2000 hektárra

\begin{tabular}{|c|c|c|c|c|c|}
\hline \multirow{2}{*}{\multicolumn{2}{|c|}{ Megnevezés }} & \multirow{2}{*}{$\begin{array}{c}\text { Mennyiség } \\
\text { darab }\end{array}$} & & \multirow{2}{*}{$\begin{array}{l}\text { Ár, átlag } \\
\text { millió HUF } \\
\end{array}$} & \multirow[t]{2}{*}{$\begin{array}{c}\text { Beszerzési } \\
\text { költség }\end{array}$} \\
\hline & & & & & \\
\hline \multirow{2}{*}{ Erőgép } & $300 \mathrm{LE}$ traktor & 2 & $50-60$ & 55 & 110 \\
\hline & 100-150 LE traktor & 2 & $20-40$ & 30 & 60 \\
\hline Önjáró permetező & & 1 & $40-100$ & 70 & 70 \\
\hline Kombájn & & 2 & $40-130$ & 85 & 170 \\
\hline Eke & & 3 & $6-10$ & 8 & 24 \\
\hline Lazító & & 2 & $3-5$ & 4 & 8 \\
\hline Kultivátor & & 2 & $10-15$ & 12,5 & 25 \\
\hline Elmunkáló & & 1 & $8-15$ & 11,5 & 11,5 \\
\hline Kukoricavető & & 2 & $20-45$ & 32,5 & 65 \\
\hline Gabonavető & & 1 & $10-20$ & 15 & 15 \\
\hline Tartálykocsi & & 2 & $5-10$ & 7,5 & 15 \\
\hline Bálázó & & 1 & $15-40$ & 27,5 & 27,5 \\
\hline Rakodógép & & 1 & $15-30$ & 22,5 & 22,5 \\
\hline Átrakókocsi & & 2 & $10-15$ & 12,5 & 25 \\
\hline Szaktanácsadás & & 2000 & & 0,002 & 4 \\
\hline Szoftverek & & & & & 3,6 \\
\hline Összesen & & & & & 656,1 \\
\hline
\end{tabular}

Forrás: KITE Zrt. 
21. melléklet: Komplett gépparkcsere eszközei és költségei 500 hektárra

\begin{tabular}{lccccc}
\hline \multirow{2}{*}{ Megnevezés } & Mennyiség & Ár, tól-ig & Ár, átlag & $\begin{array}{c}\text { Beszerzési } \\
\text { költség }\end{array}$ \\
\cline { 2 - 6 } & darab & & millió HUF & \\
\hline \multirow{2}{*}{ Erőgép } & 300 LE traktor & 1 & $50-60$ & 55 & 55 \\
\cline { 2 - 6 } & 100-150 LE traktor & 2 & $20-40$ & 30 & 60 \\
\hline Vontatott permetező & 1 & $5-20$ & 12,5 & 12,5 \\
\hline Kombájn (nem mindenkinek van) & 1 & $40-130$ & 85 & 85 \\
\hline Eke & 1 & $6-10$ & 8 & 8 \\
\hline Lazító & 1 & $3-5$ & 4 & 4 \\
\hline Magágykészítő & 1 & $8-15$ & 11,5 & 11,5 \\
\hline Kultivátor & 1 & $3-8$ & 5,5 & 5,5 \\
\hline Vetőgép (kukorica) & 6 soros & 1 & $10-25$ & 11,75 & 11,75 \\
\hline Gabonavetögép & 1 & $6-15$ & 10,5 & 10,5 \\
\hline Emelővilla kistraktorra (rakodóra nem költ) & 1 & 3 & 3 & 3 \\
\hline Szaktanácsadás & 500 & & 0,002 & 1 \\
\hline Összesen & & & & 267,75 \\
\hline
\end{tabular}

Forrás: KITE Zrt.

22. melléklet: Precíziós elemekkel történő felszerelés eszközei és költségei 2000 hektárra

\begin{tabular}{lcccc}
\hline \multirow{2}{*}{ Megnevezés } & Mennyiség & Ár, tól-ig & Ár, átlag & $\begin{array}{c}\text { Beszerzési } \\
\text { költség }\end{array}$ \\
\cline { 2 - 5 } & darab & & millió HUF & \\
\hline Antenna+monitor nagytraktorra & 2 & $4-5$ & 4,5 & 9 \\
\hline $\begin{array}{l}\text { Hozamtérképezö + } \\
\text { automata kormányzás kombájnra }\end{array}$ & 2 & $\begin{array}{c}1,5 \text { millió + 4-5 } \\
\text { millió }\end{array}$ & 6 & 12 \\
\hline Vetögép (árkülönbség) & 3 & $5-10$ & 7,5 & 22,5 \\
\hline Pótkocsi keréknyomásos rendszer & 2 & $1,5-2$ & 1,75 & 3,5 \\
\hline Szaktanácsadás & 2000 & & 0,002 & 4 \\
\hline Szoftverek & & & & 3,6 \\
\hline Összesen & & & & 54,6 \\
\hline
\end{tabular}

Forrás: KITE Zrt. 
23. melléklet: Precíziós elemekkel történő felszerelés eszközei és költségei 500 hektárra

\begin{tabular}{lcccc}
\hline \multicolumn{1}{c}{ Megnevezés } & Mennyiség & Ár, tól-ig & Ár, átlag & $\begin{array}{c}\text { Beszerzési } \\
\text { költség }\end{array}$ \\
\cline { 2 - 5 } & darab & & millió HUF \\
\hline Antenna+monitor nagytraktorra & 1 & $4-5$ & 4,5 & 4,5 \\
\hline $\begin{array}{l}\text { Hozamtérképezö + } \\
\text { automata kormányzás kombájnra }\end{array}$ & 1 & $\begin{array}{c}1,5 \text { millió }+4-5 \\
\text { millió }\end{array}$ & 6 & 6 \\
\hline Vetőgép (árkülönbség) & 2 & $5-10$ & 7,5 & 15 \\
\hline Szaktanácsadás & 500 & & 0,002 & 3,6 \\
\hline Szoftverek & & & & 30,1 \\
\hline Összesen & & & & 1 \\
\hline
\end{tabular}

Forrás: KITE Zrt.

24. melléklet: Szoftveres felszereltség elemei és költségei 2000 hektárra

\begin{tabular}{lcccc}
\hline \multirow{2}{*}{ Megnevezés } & Mennyiség & Ár, tól-ig & Ár, átlag & $\begin{array}{c}\text { Beszerzési } \\
\text { költség }\end{array}$ \\
\cline { 2 - 5 } & darab & & millió HUF \\
\hline Szaktanácsadás & 2000 & & 0,002 & 4 \\
\hline RTK-jel & 6 & $0,125-0,250$ & 0,1875 & 2 \\
\hline Szoftverek & & & & 7,125 \\
\hline Összesen & & & \\
\hline
\end{tabular}

Forrás: KITE Zrt.

25. melléklet: Szoftveres felszereltség elemei és költségei 500 hektárra

\begin{tabular}{|c|c|c|c|c|}
\hline \multirow[t]{2}{*}{ Megnevezés } & Mennyiség & Ár, tól-ig & Ár, átlag & $\begin{array}{c}\text { Beszerzési } \\
\text { költség }\end{array}$ \\
\hline & darab & & millió HUF & \\
\hline Szaktanácsadás & 500 & & 0,002 & 1 \\
\hline Szoftverek & & & & 2 \\
\hline Összesen & & & & 3 \\
\hline
\end{tabular}

Forrás: KITE Zrt. 



\section{Hivatkozások jegyzéke}

1. AIOTI (2015): Smart farming and food safety Internet of Things applications - Challenges for large scale implementations. Alliance for Internet of Things Innovation (AIOTI), Brussels, $49 \mathrm{p}$.

2. Ambrus A., Burai P., Lénárt Cs., Enyedi P., Kovács Z. (2015): Estimating biomass of winter wheat using narrowband vegetation indices for precision agriculture. Journal of Central European Green Innovation 3 (2): 13-22.

3. American Farm Bureau (2014): American farm bureau survey shows big data use increasing, big questions remain. http://www.fb.org/newsroom/news_article/178/

4. American Farm Bureau (2016): Privacy and security principles for farm data. http://www.fb.org/tmp/uploads/PrivacyAndSecurityPrinciplesForFarmData.pdf

5. Anisi, M. H., Abdul-Salaam, G., Abdullah, A. H. (2015): A survey of wireless sensor network approaches and their energy consumption for monitoring farm fields in precision agriculture. Precision Agriculture 16: 216-238. DOI 10.1007/s11119-014-9371-8

6. Antolini, L. S., Scare, R. F., Dias, A. (2015): Adoption of precision agriculture technologies by farmers: a systematic literature review and proposition of an integrated conceptual framework. IFAMA World Conference June 14-17, 2015, Saint Paul, Minnesota, USA. Paper 1259. http://docplayer.net/4068154-Adoption-of-precision-agriculture-technologies-by-farmers-asystematic-literature-review-and-proposition-of-an-integrated-conceptual-framework.html

7. Aubert, B. A., Schroeder, A., Grimaudo, J. (2012): IT as enabler of sustainable farming: An empirical analysis of farmers' adoption decision of precision agriculture technology. Decision Support Systems 54: 510-520. http://dx.doi.org/10.1016/j.dss.2012.07.002

8. Auernhammer, H. (2001): Precision farming - the environmental challenge. Computer and Electronics in Agriculture 30: 31-43.

9. Ádám J. (2007): Globális geodéziai megfigyelőrendszer. Magyar Tudomány 167 (5): 563-576.

10. Balsari, P., Marucco, P., Tamagnone, M. (2009): A crop identification system (CIS) to optimise pesticide applications in orchards. Journal of Horticultural Science \& Biotechnology ISAFRUIT Special Issue 113-116.

11. Banhazi, T. M., Lehr, H., Black, J. L., Crabtree, H., Schofield, P., Tscharke, M., Berckmans, D. (2012): Precision livestock farming: an international review of scientific and commercial aspects. Int. J. Agric \& Biol Eng. 5 (3): 1-9.

12. Benedek Sz. (2011): Precíziós tápanyag-gazdálkodási technológiák alkalmazása Dalmandon. Agro Napló 5: 45-46.

http://agronaplo.hu/szakfolyoirat/2011/05/szantofold/precizios-tapanyag-gazdalkodasitechnologiak-alkalmazasa-dalmandon

13. Berckmans, D. (2014): Precision livestock farming technologies for welfare management in intensive livestock systems. Rev. sci. tech. Off. int. Epiz. 33 (1): 189-196.

14. Béri B. (2011): Tartástechnológia - Automatizálás az állattenyésztésben. Debreceni Egyetem, Nyugat-Magyarországi Egyetem, Pannon Egyetem

http://www.tankonyvtar.hu/hu/tartalom/tamop425/0010_1A_Book_15_Tartastechnologia/ ch14.html 
15. Bernardi, A. C. de C., Inamasu, R. Y. (2014): Adoção da agricultura de precisão no Brasil. In Bernardi, A. C. de C., Naime, J. de M., Resende, A. V. de, Bassoi, L. H., Inamasu, R. Y. (eds): Agricultura de precisão: resultados de um novo olhar. Brasília, DF, Embrapa, 559-577.

16. Berry, J. K. (1999): The precision farming primer-GIS technology and site-specific management in production agriculture. BASIS Inc., Colorado, USA http://www.innovativegis.com/basis/pfprimer/

17. Biermacher, J. T., Epplin, F. M., Brorsen, B. W., Solie, J. B., Raun, W. R. (2009): Economic feasibility of site-specific optical sensing for managing nitrogen fertilizer for growing wheat. Precisicion Agriculture 10: 213-230.

18. Birkás M. (1997): A talajhasználat és talajművelés EU-konform fejlesztésének területei, rövid és hosszútávú teendői. In Kerekes S., Kiss K. (szerk.): Zöld belépő: EU-csatlakozásunk környezeti szempontú vizsgálata. BKÁE, Budapest

19. Birkás M. (2008): A mulcsmüvelés hazai gyakorlata. Agrofórum 19 (8): 27-30.

20. Blackmore, B. S., Griepentrog, H-W. (2002): A future view of precision farming. KTBL Sonderveröffentlichung, Vol. 038: 131-145.

21. Blackmore, S. (2016a): Farming with robots. PREGA konferencia, 2016. 02. 22., Budapest

22. Blackmore, S. (2016b): Toward robotic agriculture. Smart technologies for sustainable agriculture, Symposium Handouts, London

http://adamchukpa.mcgill.ca/ukca_workshop/UK-Canada_Workshop_2016_Handouts.pdf

23. Blackshaw, R. E., O’Donovan, J. T., Harker, K. N., Clayton, G. W., Stougaard, R. N. (2006): Reduced herbicide doses in field crops: A review. Weed Biology and Management 6: 10-17.

24. Bora, G. C., Nowatzki, J. F., Roberts, D. C. (2012): Energy savings by adopting precision agriculture in rural USA. Sustainability and Society 2 (22)

25. Borsiczky I., Reisinger P. (2013): Precíziós megoldások a gyomnövények ellen. Biokultúra $2013 / 2$

26. Business Intelligence and Strategy Research (2015): Precision Irrigation Market - By System (Sprinkler System, Center Pivot System, Variable Rate Irrigation, \& Service); Application (Agriculture, Sport, Public Park, Garden, Lawn, and Greenhouse \& Nursery) - Global Analysis \& Forecast, 2015 to 2020.

http://bisresearch.com/industry-verticals/agriculture-technologies/precision-irrigation-marketresearch-report-forecast-610.html

27. Business Intelligence and Strategy Research (2016): Global Precision Agriculture Market Analysis \& Forecast, 2016-2022.

http://bisresearch.com/industry-verticals/agriculture-technologies/global-precision-agricultureindustry-forecast.html

28. Castle, M., Lubben, B. D., Luck, J. (2015): Precision agriculture usage and big agriculture data. Cornhusker Economics. University of Nebraska http://agecon.unl.edu/precision-agriculture-usage-and-big-agriculture-data

29. CEMA (2014): Precision farming - producing more with less. http://www.cema-agri.org/page/precision-farming-0 
30. CEMA (2015): Towards a New Strategic Agenda for the Common Agricultural Policy (CAP) after 2020.

http://cema-agri.org/sites/default/files/publications/A New Strategic Agenda for the CAP after 2020.pdf

31. Chavas, J. P. (2008): A cost approach to economic analysis under state-contingent production uncertainty. American Journal of Agricultural Economics 90(2): 435-446.

32. Copa - Cogeca (2016a): Main principles underpinning the collection, use and exchange of agricultural data. QJ(16)2689:6 - DA/FG/mvs.

http://www.copa-cogeca.be/Download.ashx?ID=1566736\&fmt=pdf

33. Copa - Cogeca (2016b): Position of European farmers and cooperatives on the use of remotely pilotes aircaftsystems (RPAS) in agriculture. AT(16)1807:4 - DA/mvs.

http://www.copa-cogeca.be/Download.ashx?ID=1513051\&fmt=pdf

34. Corsini, L., Wagner, K., Gocke, A., Kurth, T. (2015): Crop farming 2030 - The reinvention of the sector. Boston Consulting Group

35. Csathó P., Horváth J., Mesterházi P. Á., Milics G., Nagy L., Neményi M., Németh T., Pecze Zs., Szabó J. (2007): Hazai gyakorlati tapasztalatok. In Németh T., Neményi M., Harnos Zs. (szerk.): A precíziós mezőgazdaság módszertana. JATE PRESS - MTA TAKI, Szeged, 229-239.

36. Davies, J. (2016): How sound technology detects health problems in broilers. Farmers Weekly http://www.fwi.co.uk/poultry/how-sound-technology-detects-health-problems-in-broilers.htm

37. DEFRA (2013): Farm practices survey October 2012 - Current farming issues. Department for Environment, Food \& Rural Affairs, UK

https://www.gov.uk/government/statistics/farm-practices-survey-october-2012-currentfarming-issues

38. Demes Gy. (2015): Az erózió elleni védelem a KITE és a JOHN DEERE precíziós megoldásaival. Agrofórum Online

http://www.agroforum.hu/hirek/az-erozio-elleni-vedelem-kite-es-john-deere-preciziosmegoldasaival

39. Doruchowski, G., Swiechowski, W., Godyn, A., Holownicki, R. (2011): Automatically controlled sprayer to implement spray drift reducing application strategies in orchards. Journal of Fruit and Ornamental Plant Research 19 (1): 175-182.

40. Dressler, N., Gundermann, S., Keese, S., Aulbur, W., Zhang, J., Amichi, S., Marinoni, A., Nagashima, S., Cherkin, E. (2015): Business opportunities in Precision Farming: Will big data feed the world in the future? Roland Berger Strategy Consultants $\mathrm{GmbH}$

https://www.rolandberger.com/publications/publication_pdf/roland_berger_business_ opportunities_in_precision_farming_20150803.pdf

41. EASA (2015): Javaslat a drónok üzemeltetésére vonatkozó közös európai szabályozás létrehozására.

https://www.easa.europa.eu/download/ANPA-translations/205933_EASA_Summary of the ANPA_HU.pdf

42. EC (2016): Horizon 2020 Work Program 2016-2017. Food security, sustainable agriculture and forestry, marine and maritime and inland water research and bioeconomy. http://ec.europa.eu/research/participants/data/ref/h2020/wp/2016_2017/main/h2020-wp1617food_en.pdf 
43. EIP-AGRI (2015): Precision Farming Final Report.

https://ec.europa.eu/eip/agriculture/sites/agri-eip/files/eip-agri_focus_group_on_precision_ farming_final_report_2015.pdf

44. EK (2009): Az Európai Parlament és a Tanács 2009/24/EK irányelve (2009. április 23.) a számítógépi programok jogi védelméröl.

45. EP (2016): Az innováció és a gazdasági fejlődés előmozdítása a jövőbeli európai mezőgazdasági gazdálkodásban. Európai Parlament 2016. június 7-i állásfoglalása.

http://www.europarl.europa.eu/sides/getDoc.do?pubRef=-//P//TEXT+TA+P8-TA-2016$0252+0+\mathrm{DOC}+\mathrm{XML}+\mathrm{V} 0 / / \mathrm{HU}$

46. Erickson, B., Widmar, D. A. (2015): Precision agricultural services dealership survey results. Dept. of Agricultural Economics, Purdue University, West Lafayette, Indiana, USA, 37 p. http://agribusiness.purdue.edu/files/resources/2015-crop-life-purdue-precision-dealer-survey.pdf

47. ESA (2010): ESA's TalkingFields guides European farmers from space.

http://www.esa.int/Our_Activities/Space_Engineering_Technology/TTP2/ESA_S_ TalkingFields_guides_European_farmers_from_space

48. EU (2016): Az Európai Parlament és a Tanács (EU) 2016/679 Rendelete (2016. április 27.) természetes személyeknek a személyes adatok kezelése tekintetében történő védelméről és az ilyen adatok szabad áramlásáról, valamint a 95/46/EK rendelet hatályon kívül helyezéséről (általános adatvédelmi rendelet).

49. EurActiv (2016): Precision agriculture: future of the CAP? Stakeholder conference, https://www.euractiv.com/section/agriculture-food/video/precision-agriculture-future-of-the-cap/

50. European GNSS Agency (2015): GNSS Market Report, Issue 4. - Agriculture. Publication Office of the EU, Luxemburg, 56-63. https://www.gsa.europa.eu/sites/default/files/Agriculture_0.pdf

51. Farkas I. (2015): Robotpilóta-rendszerek a precíziós gazdálkodásban. Agroinform.hu http://www.agroinform.com/gepeszet/robotpilota-rendszerek-a-precizios-azdalkodasban-21555

52. Ferencsik S. (2015): A kukorica hagyományos és csökkentett menetszámú talajművelési rendszereinek komplex elemzése. PhD-értekezés (Debreceni Egyetem Kerpely Kálmán Doktori Iskola). $120 \mathrm{p}$.

53. FM (2016): Magyarország élelmiszergazdasági programja 2016-2050. http://www.kormany.hu/download/7/30/d0000/Élelmiszergazdasági stratégia 2016-2050.pdf

54. Franzen, D., Mulla, D. (2015): A history of precision farming. In Zhang Q. (ed.): Precision agriculture technology for crop farming. CRC Press, Boca Raton/London/New York, 1-20.

55. Fontana, I., Tullo, E., Fernandez, A. P., Berckmans, D., Koenders, E., Vranken, E., McKinstry, J., Butterworth, A., Guarino, M. (2015): Frequency analysis of vocalisations in relation to the growth in broiler chicken. Proceedings of 7 th European Conference on Precision Livestock Farming, Milan, Italy, 174-182.

56. Fountas, A., Pedersen, S. M., Blackmore, S. (2005): ICT in Precision agriculture - diffusion of technology. In Gelb, E., Offer, A. (eds.): ICT in agriculture: perspective of technological innovation. http://departments.agri.huji.ac.il/economics/gelb-pedersen-5.pdf

57. Fountas, S., Carli, G., Sorensen, C. G., Tsiropoulos, Z., Cavalaris, C., Vatsanidou, A., Liakos, B., Canavari, M., Wiebensohn, J., Tisserye, B. (2015): Farm management information systems: Current situation and future perspectives. Computers and Electronics in Agriculture 115: 40-50. 
58. Gandonou, J. M., Dillon, C., Harman, W., Williams, J. (2004): Precision farming as a tool in reducing environmental damages in developing countries: a case study of cotton production in Benin. American Agricultural Economics Association. Annual Meeting. http://ageconsearch.umn.edu/bitstream/20086/1/sp04ga02.pdf [Letöltve: 2008.11.15.] 22 p.

59. Győrffy B. (2000): A biogazdálkodástól a precíziós mezőgazdaságig. Agrofórum 11 (2): 1-4.

60. Hajdú J. (2015): Öntözni csak kíméletesen és precíziósan szabad. Mezőgazdasági Technika 3: $18-20$.

61. Haszon Agrár Magazin (2013): Mikro öntözés - maxi haszon. http://www.haszonagrar.hu/mezogepek/992-mikro-oentoezes-maxi-haszon.html

62. Hedley, C. (2010): Precision irrigation scheduling. Landcare Research, NZ. http://www.precisionirrigation.co.nz/en/downloads/file/4/

63. Hogan, P. (2016): Europe's opportunity in digital agriculture. EU Workshop 14th January 2016, Brussels.

http://ec.europa.eu/agriculture/commissioner-speeches/pdf/hogan-digital-agricultureworkshop-14-01-2016_en.pdf

64. Husti I. (2015): A sávművelés néhány müszaki-ökonómiai kérdése hazánkban. Mezőgazdasági Technika 56 (8): 26-29.

65. INTA (2013): Competitividad y eficiencia - Tecnología precisa. INTA informa Año XII. \#135 http://intainforma.inta.gov.ar/wp-content/uploads/2013/06/135_AP.pdf

66. IVSZ (2016a): Nemzeti e-agrárium stratégia helyzetkép. http://www.slideshare.net/IVSZ/nemzeti-eagrrium-stratgia-helyzetkp

67. IVSZ (2016b): Digitális Agrár Stratégia. http://ivsz.hu/wp-content/uploads/2016/06/ivsz-digitalis-agrar-strategia-2016.pdf

68. Jacobsen, L-B., Pedersen, S. M., Jensen, H. G., Kirketerp-Scavenius, I. M. (2011): Socioeconomic impact of widespread adoption of precision farming and controlled traffic systems. Future Farm Project. 1-24.

http://www.futurefarm.eu/system/files/FFD5.8_Socioeconomic_Impact_PF_CTF_final.pdf

69. Jensen, H. G., Jacobsen, L-B., Pedersen, S. M., Tavella, E. (2012): Socioenemic impact of widespread adoption of precision farming and controlled traffic systems in Denmark. Precision Agric 13: 661-677.

70. Jóri J. I., Farkas Zs., Kerényi Gy., Salamon S., Soós S., Szente M. (2007): A talajművelő gépek feladatai, lehetőségei és müszaki megoldásai a számítógéppel támogatott mezőgazdaságban (CAF). OTKA Munkabeszámoló. http://real.mtak.hu/1032/1/43355_ZJ1.pdf

71. Jung A., Hegedüs B., Drexler D. (2015a): Field spectroscopy for precision organic production. Acta fytotechn. zootechn. 18 (Special Issue): 68-70. DOI 10.15414/afz.2015.18.si.68-70

72. Jung, A., Vohland, M., Thiele-Bruhn, S. (2015b): Use of a portable camera for proximal soil sensing with hyperspectral image data. Remote Sensing 7: 11434-11448. DOI 10.3390/ rs70911434

73. Kalmár S. (2010): A precíziós növénytermelés üzemgazdasági összefüggései. PhD-értekezés (NYME Mezőgazdasági és Élelmiszertudományi Kar). 158 p.

74. Karpjuk Gy. (2016): A GPS-technológia alkalmazása a mezőgazdasági bérvállalkozásban. In Erdei G., Milics G. (szerk.): Precíziós Gazdálkodás - Digitalizáción innen és túl. 35. p. 
75. KITE (2015): KITE precíziós gazdálkodás. http://www.precgazd.hu/letoltesek

76. KITE (2016a): Erózió elleni védelem precíziós megoldásai. http://www.precgazd.hu/letoltesek

77. KITE (2016b): Itt az ideje a precíziós öntözésnek. http://www.kite.hu/hirek/itt_az_ideje_a_precizios_oentoezesnek/172

78. KITE (2016c): Komplex szaktanácsadási szolgáltatás. http://www.precgazd.hu/letoltesek

79. Kovács K. (2011): Informatika az állattenyésztésben. Agrárium 21: 6-7.

80. Könyves L., Reibling T., Bodor A., Brydl E., Adorján A., Solymosi N. (2015): Egy precíziós állattartási projekt tapasztalatai. Magyar Állatorvosok Lapja 137 (12): 719-727.

81. KSH (2015): A gazdaságok jellemzői a 2013. évi gazdaságszerkezeti összeírás alapján. http://www.ksh.hu/docs/hun/xftp/idoszaki/gszo/gazdjell_gszo13.pdf

82. KSH (2016): Agrárium 2016 (előzetes adatok). Statisztikai Tükör 2016. november 22.

83. Kuroli G., Lehoczky É., Pálmai O., Reisinger P. (2007): A precíziós növényvédelem. In Németh T., Neményi M., Harnos Zs. (szerk.): A precíziós mezőgazdaság módszertana. JATE PRESS MTA TAKI, Szeged, 77-137.

84. Kuttler T., Tiemann, S., Siebert R., Fountas, S. (2011): The role of the communication and co-operation in the adoption of precision farming. Precision Agriculture 12: 2-17. DOI 10.1007/ s11119-009-9150-0

85. Lee, W. S., Alchanatis, V., Yang, C., Hirafuji, M., Moshou, D., Li, C. (2010): Sensing technologies for precision specialty crop production. Computers and Electronics in Agriculture 74: 2-33.

86. Lencsés E. (2013): A precíziós (helyspecifikus) növénytermelés gazdasági értékelése. PhDértekezés (SZIE GSZDI). 179 p.

87. Lencsés E., Takács I., Takács-György K. (2014): Farmers’ perception of precision farming technology among Hungarian farmers. Sustainability 6: 8452-8465. DOI 10.3390/su6128452

88. LLewellyn, R., Ouzman, J. (2014): Adoption of precision agriculture-related practices: status, opportunities and the role of farm advisers. Report for Grain Research and Development Corporation. CSIRO Agriculture Flagship.

89. Lowenberg-DeBoer, J., Swinton, S. M. (1997): Economics of site-specific management in agronomic crops. In Pierce, F. J., Sadlet, E. J. (eds.): The State of Site-specific Management for Agricultural Systems. Madison WI: American Society of Agronomy, Crop Science Society of America and Soil Science Society of America, 369-396.

90. Maler, T. (2015): Interview: EU precision farming needs policy support to grow. Agra Europe https://www.agra-net.com/agra/agra-europe/policy-and-legislation/environment/interview-euprecision-farming-needs-policy-support-to-grow-484952.htm

91. MarketsandMarkets (2016): Precision Farming Market by Technology (Guidance Systems, Remote Sensing, and Variable Rate Technology), by Hardware (Display, GPS/GNSS Devices, Yield Monitor, and Sensor) and Software \& Services, Application, and Geography - Global Forecast to 2020.

http://www.marketsandmarkets.com/Market-Reports/precision-farming-market-1243.html

92. MASSEY FERGUSON (2014): Technológiai megoldások a Massey Fergusontól. http://www.bedenek.hu/prospektusok/15372_MF_Tech_solutions_24pp_Hungarian.pdf 
93. Matese, A., Di Gennaro, A. F. (2015): Technology in precision viticulture: a state of the art review. International Journal of Wine Research 7: 69-81.

94. Mesterházi P. Á. (2013): Development of measurement technique for GPS-aided plant production. Doctoral Dissertation (University of West-Hungary). $143 \mathrm{p}$.

95. Milics G., Neményi M. (2007): Az adatgyüjtés müszaki és informatikai háttere. In Németh T., Neményi M., Harnos Zs. (szerk.): A precíziós mezőgazdaság módszertana. JATE PRESS MTA TAKI, Szeged, 139-158.

96. Milics G., Neményi M., Mesterházi P. Á. (2006): Növényi kártevők érzékelése infraszenzorral. In Takácsné György K. (szerk.): Növényvédő szer használat csökkentés gazdasági hatásai. Szent István Egyetemi Kiadó, Gödöllő, 41-45.

97. Milics G., Smuk N., Pörneczi A. (2014): Precíziós gazdálkodás 2. A hozamméréstől a hozamtérképig. Agrofórum Extra 57: 90-93.

98. Milics G., Tamás J. (2007): Helymeghatározás. In Németh T., Neményi M., Harnos Zs. (szerk.): A precíziós mezőgazdaság módszertana. JATE PRESS - MTA TAKI, Szeged, 15-37.

99. MINAGRO (2015): Deere\&Company Will Launch New Projects in Ukraine. Ministry of Agrarian Policy and Food of Ukraine, http://minagro.gov.ua/en/node/16480

100. Mogyorósi B., Schmidt R., Gergely I., Schmidt P. (2011): OptRXTM szenzor alkalmazásával meghatározott nitrogénfejtrágya-adagok hatása az őszi búza nedvessikér-tartalmára. Acta Agronomica Óváriensis 53 (2): 3-14.

101. Molnár I., Pecze Zs. (2002): Precíziós gazdálkodási technológia Baracskán. Börtönügyi Szemle 21 (4): 139-146.

http://epa.oszk.hu/02700/02705/00052/pdf/EPA02705_bortonugyi_szemle_2002_4_139-146.pdf

102. Montgomery, J., Hornbuckle, J., Hume, I., Vleeshouver, J. (2015): IrriSAT - weather based scheduling and benchmarking technology. In Acuña, T., Moeller, C., Parsons, D., Harrison, M. (eds.): Building Productive, Diverse and Sustainable Landscapes. Proceedings of the 17th Australian Agronomy Conference 2015, 21-24 September 2015, Hobart, Tas.

http://www.agronomy2015.com.au/papers/agronomy2015final00449.pdf

103. Nagy A., Riczu P., Tamás J. (2014): Almafa lisztharmat (Podosphaera leucotricha) okozta stressz tüneteinek spektrális érzékelése. Agrártudományi Közlemények 55: 83-88.

104. Nagy B. (2012): Megéri-e GPS-t használni a mezőgazdasági növénytermesztésben? Agrárágazat 2012. február, 78-80.

105. Neményi M., Mesterházi P. Á., Pecze Zs., Stépán Zs. (2003): The role of GIS and GPS in precision farming. Computers and Electronics in Agriculture 40: 45-55.

106. Neményi M., Pecze Zs., Mesterházi P. Á., Németh T. (2001): A precíziós-helyspecifikus növénytermesztés müszaki és térinformatikai feltételrendszere. Növénytermelés 50 (4): 419430.

107. Németh T., Neményi M., Harnos Zs. (szerk.) (2007): A precíziós mezőgazdaság módszertana. JATE PRESS - MTA TAKI, Szeged, 240 p.

108. Neuwald T., Tuzson G. (2016): Közelgő drón szabályozás változások. Drónpilóták Országos Egyesülete http://fpvegyesulet.hu/kozelgo-dron-szabalyozas-valtozasok/ 
109. NFM (2016): A pilóta nélküli légijármüvekről szóló előterjesztés. Nemzeti Fejlesztési Minisztérium, 2016. december 23.

http://www.kormany.hu/hu/dok? source=9\&year=2016\#!DocumentBrowse

110. Noel G. (2003): Szántóföldi kertészeti kultúrák öntözése a KITE Rt. mikroöntöző rendszerével. Agrárágazat 4(5): 30.

http://www.pointernet.pds.hu/ujsagok/agraragazat/2003/06/20090210201212896000000410.html

111. Nuske, S., Achar, S., Bates, T., Narasimhan, S., Singh, S. (2011): Yield estimation in vineyards by visual grape detection. International Conference on Intelligent Robots and Systems (IROS), 25-30 Sept. 2011, San Francisco, CA, 2652-2358.

http://www.cs.cmu.edu/ sachar/grape_iros2011.pdf

112. OECD (2016): Farm management practices to foster green growth. OECD Publishing, Paris. DOI $10.1787 / 9789264238657$-en

113. Qian, J-P., Yang, X-T., Wu X-M., Xing B., Wu, B-G., Li, M. (2015): Farm and environment information bidirectional aqusution system with individual tree identification using smartphones for orchard precision management. Computers and Electronics in Agriculture 116: 101-108.

114. Pecze Zs. (2009): Az IKR Zrt. fejlesztési eredményei a precíziós gyomirtásban. Dr. Ujvárosi Miklós Gyomismereti Társaság és a Magyar Gyomkutató Társaság Konferenciája, 2009. március 5-7., Salgótarján, http://www.hwrs.hu/download/hazai/ujvarosi2009.pdf

115. Pecze Zs. (2015): TALAJINFO - gyors, precíz és áttekinthető megoldás. Agrár Horizont 2 (1): 36-38.

116. Pólya Á., Varanka M. (2015): Információszerzés és döntéstámogatás az agráriumban. Piackutatási jelentés. AgroStratéga,

http://agrostratega.hu/letoltesek/AgroStratega_kutatasi_jelentes_2015_standard.pdf

117. Reisinger P. (2012): A precíziós növénytermesztés hazai helyzete, eddig elért fejlesztési eredmények és perspektívák. Magyar Gyomkutatás és Technológia XIII. (1): 3-19.

118. Riczu P., Csihon Á., Nagy G., Nagy A., Tamás J. (2016): Lézerszkenner alapú almadetektálás. Gradus 3 (1): 263-267.

119. Riczu P., Mesterházi P. Á., Fórián T., Fehér G., Bíró J., Tamás J. (2012): Mezőgazdasági erőgépek automatikus kormányzásának pontossági vizsgálata. In Lóki J. (szerk.): Az elmélet és a gyakorlat találkozása a térinformatikában III. Debreceni Egyetemi Kiadó, Debrecen, 337-344.

120. Riczu P., Nagy A., Bozsik É., Gálya B., Mesterházi P. Á., Tamás J. (2013): Complex vegetation survey in a fruit plantation by spectral instruments. Agricultural Informatics 4 (2): 37-42.

121. Riczu P., Tamás J. (2013): Intenzív almaültetvény mikrodomborzat-vizsgálata precíziós eszközök alkalmazásával. Magyar Hidrológiai Társaság XXXI. Országos Vándorgyűlés, 2013. július 3-5. Gödöllö, http://www.hidrologia.hu/vandorgyules/31/dolgozatok/word/174_riczu_peter.pdf

122. Rider, T. W., Vogel, J. W., Dille, J. A., Dhuyvetter, K. C., Kastens, T. L. (2006): An economic evaluation of site-specific herbicide application. Precision Agriculture 7: 379-392.

123. Romeo, S. (2016): Overview on smart farming - White Paper, Beecham Research, http://www.rethinkevents.com/wp/wp-content/uploads/2016/01/BRL-Smart-Farming-WhitePaper-2015-SR.pdf 
124. Sa, J., Ju, M., Han, S., Kim, H., Chung, Y., Park, D. (2015): Detection of low-weight pigs by using a top-view camera. Proceedings of ISCC 18-19 December 2015, Guangzhou, China, Paper 24 http://pos.sissa.it/archive/conferences/264/024/ISCC2015_024.pdf

125. Schiffer, J., Dillon, C. (2014): The economic and environmental impacts of precision agriculture and interactions with agro-environmental policy. Precision Agric 16: 46-61

126. Schimmelpfenning, D., Ebel, R. (2011): On the doorstep of the information age: Recent adoption of precision agriculture. Economic Information Bullettin 80., USDA, 31 p.

127. Schumann, A. W. (2010): Precise placement and variable rate fertilizer application technologies for horticultural crops. HortTechnology 20 (1): 34-40.

128. Sinka A., Mesterházi P. Á. (2014): Effects of precision farming in large scale farming practice. Journal of Central European Green Innovation 2 (4): 119-128.

129. Sinka A., Takácsné György K. (2010): A sávpermetezés jelentősége a kukorica gyomszabályozásában. In Lukács G., Sürű B. (szerk.): Gazdaságosság és/vagy biodiverzitás. LII. Georgikon napok kivonatkötete. Pannon Egyetem Georgikon Kar, Keszthely, 1-10.

130. Smuk N., Milics G., Neményi M. (2010): Jövedelemtérképek a precíziós növénytermelésben. Gazdálkodás 54 (2): 176-181.

131. Smuk N., Milics G., Salamon L., Neményi M. (2009): A precíziós gazdálkodás beruházásainak megtérülése. Gazdálkodás 53 (3): 246-253.

132. Soane, B. D., Van Ouwerkerk, C. (1998): Soil compaction: A global threat to sustainable land use. Advances in GeoEcology 31: 517-525.

133. Stafford, J. V., Ambler, B. (1994): In-field location using GPS for spatially variable field operations. Computers and Electronics in Agriculture 11: 23-36.

134. Steinhauser, G. (2014): CLAAS Telematics - Alapfelszereltség és három verzió. Agritech 2014. szeptember, 6-7.

http://www.axial.hu/upload_files/flippingbook/1411649888-agritech-201403.pdf

135. STOA (2016): Precision agriculture and the future of farming in Europe. EU, Brussels. http://www.europarl.europa.eu/RegData/etudes/STUD/2016/581892/EPRS_TU(2016)581892_ EN.pdf

136. Stombaugh, T. S., Mueller, T. G., Shearer, S. A., Dillon, C. R., Henson, G. T. (2001): Guidelines for adopting precision agricultural practices. PA-2. Cooperative Extension Service, University of Kentucky, 4.

137. Sulyok D. (2005): Különböző talajművelési rendszerek agronómiai és ökonómiai értékelése. Agrártudományi Közlemények 16: 255-258.

138. Sulyok D. (2012): A precíziós kukoricatermesztés gazdasági kérdései csernozjom talajon. Acta Agraria Debreceniensis 49: 293-296.

139. Sulyok D. (2016): A precíziós gazdálkodás a Balogh-Farmon. A profi gazdálkodók napja, 2016.11.03, Kecskemét

140. Szabó J., Milics G., Tamás J., Pásztor L. (2007): Térinformatika a precíziós mezőgazdaságban (GIS). In Németh T., Neményi M., Harnos Zs. (szerk.): A precíziós mezőgazdaság módszertana. JATE PRESS - MTA TAKI, Szeged, 39-62.

141. Szabó Sz., Milics G. (2016): Zérótól a precíziós gazdálkodásig II. Tábla kiválasztása, elemzése talajmintázás és kiértékelés. Agronapló 4: 56-58. 
142. Szuvandzsiev P., Bakó G., Helyes L., Pék Z. (2014): Spektroszkópiás vizsgálatok alkalmazási lehetőségei a málna, a szamóca és a paradicsom minőségi paramétereinek meghatározására. Kertgazdaság 46 (1): 17-23.

143. Takács I., Baranyai Zs. (2010): A bizalom és függőség szerepe a családi gazdaságok együttmüködésében végzett gépi munkákban. Gazdálkodás 54 (7): 740-749.

144. Takács-György K. (2007): Economic aspects of chemical reduction in farming - future role of precision farming. Food Economics - Acta Agriculturae Scandinavica. Section C, 5 (2): 114 122. DOI $10.1080 / 16507540903093242$

145. Takácsné György K., Széll E., Lencsés E. (2009): Kukorica gyomirtási technológiák gazdasági értékelése. Agrofórum Extra 27: 72-75.

146. Takácsné György K. (2010): Precíziós növénytermelés növényvédő szer használatának gazdasági hatásai. Gazdálkodás 54 (4): 368-376.

147. Takácsné György K. (2011): A precíziós növénytermelés közgazdasági összefüggései. Szaktudás Kiadó Ház, Budapest, 249 p.

148. Takácsné György K., Sinka A., Lencsés E., (2011): A sávpermetezés gazdasági összefüggései üzemi tapasztalatok alapján. In: Lukács G (szerk.): Fenntarthatóság és versenyképesség? LIII. Georgikon Napok. Kivonat-kötet. Pannon Egyetem Georgikon Kar, Keszthely, 717-731.

149. Takács-György K., Takács I. (2011): Risk assessment and examination of economic aspects of precision weed management. Sustainability 3: 1114-1135. DOI 10.3390/su3081114

150. Takácsné György K. (2015): Agrárinnováció a gyakorlatban - avagy miért ilyen lassú a helyspecifikus növénytermelés terjedése? Gazdálkodás 59 (6): 517-526.

151. Tamás J. (2001): Precíziós mezőgazdaság elmélete és gyakorlata. Mezőgazdasági Szaktudás Kiadó, Budapest, 144 p.

152. Tamás J. (2002): Precíziós mezőgazdaság. Mezőgazdasági Szaktudás Kiadó, Budapest, 170 p.

153. Tamás J. (2013): Precision Agriculture. University of Debrecen, Service Sciences Methodology Centre, Debrecen, 109 p.

154. Tamás J. (2016): Amikor nincs víz a területen - aszály. MTA 187. közgyűlése.

http://mta.hu/mta_hirei/viztudomanyi-program-konferencia-ader-janos-lovasz-laszlo-nemethtamas-szollosi-nagy-andras-106633

155. Technavio (2015): Global precision agriculture market 2015-2019.

http://www.technavio.com/report/global-agricultural-equipment-precision-agriculture-market

156. Tey, Y. S., Brindal, M. (2012): Factors influencing the adoption of precision agricultural technologies: a review for policy implications. Precision Agriculture 13: 713-730. DOI 10.1007/ s11119-012-9273-6

157. Tóth Á. (2011): Rádiófrekvencián alapuló egyedazonosítási módszer alkalmazhatóságának vizsgálata különböző baromfifajokban. Doktori értekezés (Nyugat-Magyarországi Egyetem, Mosonmagyaróvár). http://doktori.nyme.hu/335/

158. Tóth B. (2015): PREGA kutatás. Agroinform.hu - Market Insight

159. Tóth L. (1998): Állattartási technika. Mezőgazdasági Szaktudás Kiadó, Budapest, 764 p.

160. Tóth L. (2013): Precíziós állattartás. Agrárium Állattartási melléklet 23 (10): 24-25. 
161. Tóth L., Bak J., Schrempf N., Fogarasi L., Barkóczi T. (2009): Adatgyüjtővel ellátott állatazonosító rendszerek. OTKA Munkabeszámoló, http://real.mtak.hu/803/1/42820_ZJ1.pdf

162. Tullo, E., Fontana, I., Guarino, M. (2013): Precision livestock farming: an overview of image and sound labelling. Proceedings of the 6th International Conference in Precision Livestock Farming, Leuven, Belgium, 30-38.

163. Underwood, E., Baldock, D., Aiking, H., Buckwell, A., Dooley, E., Frelih-Larsen, A., Naumann, S., O’Connor, C., Poláková, J., Tucker, G. (2013): A fenntartható élelmiszeripar és mezőgazdaság alternatívái az EU-ban. Összefoglaló jelentés a STOA „Technológiai alternatívák 10 milliárd ember élelmezésére” projektjéről. Európai Környezetpolitikai Intézet, London/Brüsszel

164. USDA (2013): Economic Research Service Charts, United States Department of Agriculture http://www.ers.usda.gov/

165. USDA (2016): Precision Farming Incentive. http://www.nrcs.usda.gov/wps/portal/nrcs/detail/ms/home/?cid=nrcs141p2_022781

166. Väderstad (2016): Alkalmazott eljárások. http://www.vaderstad.com/hu/tudastar/alkalmazott-eljarasok

167. Veris (2012): Precise mapping of major soil productivity indicators using on-the-go soil sensors. White Paper, Veris Technologies Inc. http://veristech.com/pdf_files/opticmapper/White_Paper_MSP3_2012.pdf

168. Vigani, M., Crezo, E. R., Barero, M. G. (2015): The determinants of wheat yields: Tha role of sustainable innovation, policies and risks in France and Hungary. JRC Science and Policy Reports. EUR 27246 EN; DOI 10.2791/470542

169. Wang, Q., Nuske, S., Bergerman, M., Singh, S. (2012): Automated crop yield estimation for apple orcsards. Proc. International Symposium on Experimental Robotics, June 2012, Quebec City https://www.ri.cmu.edu/pub_files/2012/7/2012iserApple.pdf

170. Weiss, M. D. (1996): Precision farming and spatial economic analysis: Research challanges and opportunities. American Journal of Agricultural Economics 78 (5): 1275-1280.

171. Wolf, S. A., Buttel, F. H. (1996): The political economy of precision farming. American Journal of Agricultural Economics 78 (5): 1269-1274.

172. Wulfsohn, D., Zamora Lagos, I. (2014): The use of a multirotor and high-resolution imaging for precision horticulture in Chile: an industry perspective. 12th International Conference on Precision Agriculture, Sacramento, California, USA, Paper No. 1688., 15 p.

173. Yang, Ch., Lee, W. S. (2013): Precision agricultural systems. In Zhang. Q., Pierce. F. J. (eds.): Agricultural automation, Fundamentals and practices. CRC Press, Taylor \& Francis Group, Boca Raton, 63-96.

174. Zarco-Tejada, O., Hubbard, N., Loudjani, P. (2014): Precision agriculture: an opportunity for EU farmers - Potential support with the CAP 2014-2020. EP DG for Internal Policies, http://www.europarl.europa.eu/RegData/etudes/note/join/2014/529049/IPOL-AGRI_ NT\%282014\%29529049_EN.pdf

175. Zboray Z. (2016): Az első Sentinel-2A űrfelvételek Magyarországról. Ürvilág http://www.urvilag.hu/nyomtat/gmes/20160113_az_elso_sentinel2a_urfelvetelek_ magyarorszagrol 
176. Zeigler, M., Steensland, A. (2015): 2015 Global Agricultural Productivity Report. Global Harvest Initiative, Washington DC, USA http://www.globalharvestinitiative.org/GAP/2015_GAP_Report.pdf

177. Zhang, Ch., Kovacs, J. M. (2012): The application of small unmanned aerial systems for precision agriculture: a review. Precision Agriculture 13: 693-712., DOI 10.1007/s11119-0129274-5

178. Zhang, N., Wang, M., Wang, N. (2002): Precision agriculture - a worldwide overview. Computers and Electronics in Agriculture 36: 113-132.

179. Zhang, X., Shi, L., Jia, X., Seielstad, G., Helgason, C. (2010): Zone mapping application for precision-farming: a decision support tool for variable rate application. Precision Agriculture 11: 103-114., DOI 10.1007/s11119-009-9130-4

180. Zude-Sasse, M., Fountas, S., Gemtos, T. A., Abu-Khalaf, N. (2016): Application of precision agriculture in horticultural crops. Eur. J. Hortic. Sci. 81 (2): 78-90. 